Danmarks Geologiske Undersøgelse.

II. Række. Nr. 61.

\title{
Petrology
}

\section{of the Paleocene Sedimentary Rocks of Denmark}

\author{
By \\ Helge Gry
}

With 2 Plates.

Med Dansk Résumé.

I Kommission hos

C. A. Reitzels Forlag

København

1935.

Pris: $5 \mathrm{Kr}$. 
Danmarks Geologiske Undersøgelse.

II. Række. Nr. 61.

\section{Petrology}

of the Paleocene Sedimentary

Rocks of Denmark

By

Helge Gry

With 2 Plates.

Med Dansk Résumé.

I Kommission hos

C. A. Reitzels Forlag

København 1935. 
FR. BAGGES KGL. HOFBOGTRYKKERI

KøBENHAVN 


\section{Preface.}

A the works on the petrology of the Danish sediments are only few and far between in the literature, the author of the present work has commenced upon an examination of these sediments. The author has made a commencement with the Paleocene, owing to the interesting sedimentary-petrological problems connected with it. In the Cretaceous we have sediments which mostly are organogenous or chemical calcareous rocks; in the Paleocene on the contrary the rocks are for the most part terrigenous clastic sands, marls and clays. Therefore, as the Paleocene lies transgressively over the Cretaceous, the boundary between the two represents a turning-point, both palaeogeographically and petrologically. Many characteristics in the series and the rock-types prove to be connected with this circumstance.

Great weight has been attached in this work to a thorough analysis of the rocks, and consequently the greater part of it treats of the outcrops, from which abundant material could be procured for the investigation. The material from borings through the Paleocene has been employed for elucidating the facies-variations in the series in different parts of the country.

Some of the material investigated was in the Mineralogical Museum of the University of Copenhagen (rocks from Copenhagen and Tune, some boring samples), and a large part of the boring samples were the property of Denmark's Geological Survey. Much of the material was collected by the author (rocks from Lellinge, Kerteminde, Hvalløse, Svejstrup, Ommestrup, Holme and Rugaard).

The laboratory work was done at the Mineralogical Museum, whose Director, Professor O. B. Bøggild, has given me every possible facility for my work. I owe him a great debt of gratitude for the splendid conditions under which I have been able to work at the Museum.

The microphotographs and the other photographs were taken by Mr. Chr. Halkier, to whose great skill it is due that the difficult objects can be reproduced so clearly and distinctly. I am greatly obliged to Mr. HALKIER for the interest he has displayed and the work he has put into the pictures. 
I also wish to thank the chemists of the Geological Survey, Messrs. Werner Christensen and Kr. Skousbøll Hansen, who have been kind enough to make nearly 250 calcium carbonate analyses, and Mr. AlFred Rosenkrantz at The Royal Technical College i Copenhagen who has provided me with information concerning the occurrences in Copenhagen and Hanerup.

The translation has been made by Mr. W. E. Calvert.

To Dr. Victor Madsen, the Director of Denmark's Geological Survey, I am deeply indebted, and I wish to thank him for having undertaken to include this work among the publications of the Institution. Without his interest and kindness the work would scarcely have made its appearance, and in any case not in the form in which it is now presented.

Copenhagen, September 1935

Helge Gry. 


\section{Contents.}

Intro

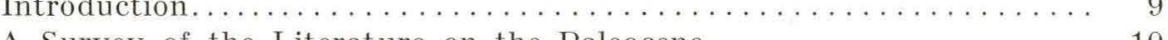

A Survey of the Literature on the Paleocene ................ 10

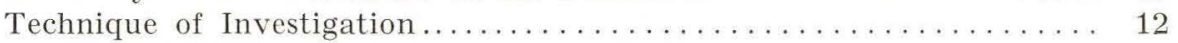

Summary of Paleocene Occurrences in Denmark .............. 16

Localities in Sealand where Greensand Predominates . . . . . . . . . 18

The Copenhagen Area ....................... 18

Petrographic Description of Rocks from Localities with Hardened

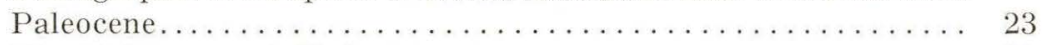

The Paleocene at Vodroffsvej................... 32

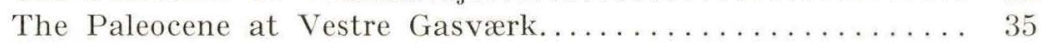

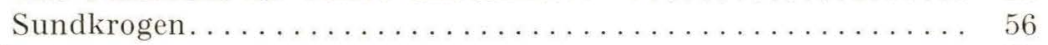

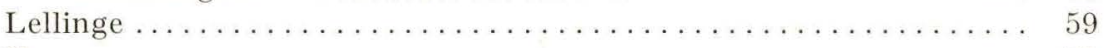

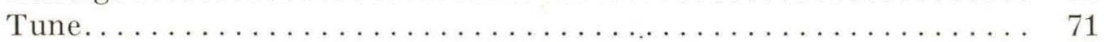

The Kerteminde Marl in Sealand and Funen............... 72

The Randers-Djursland District..................... 78

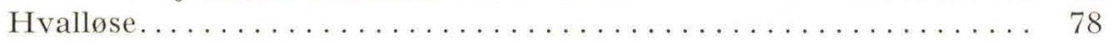

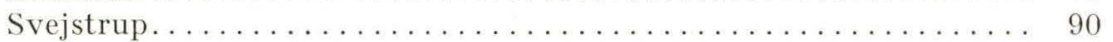

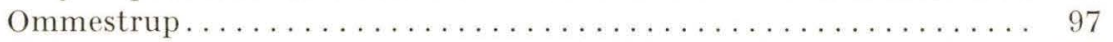

Holme. . . . . . . . . . . . . . . . . . . . . . . . . 103

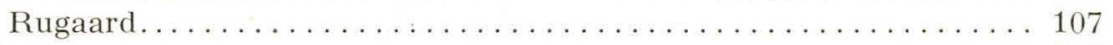

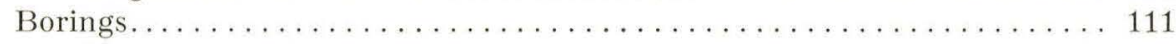

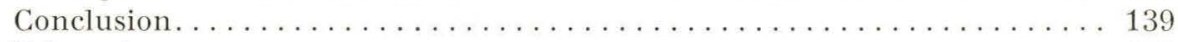

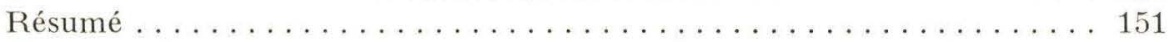

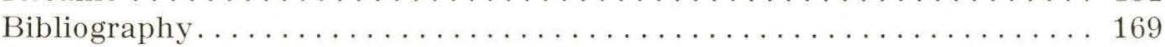

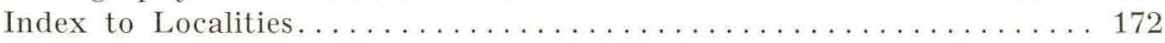




\section{List of Tables.}

All grain sizes are given as diameters in $\mathrm{mm}$.

Mechanical Analyses. Page

Table 1. Vestre Gasværk. . . . . . . . . . . . . . . . . . . . 40

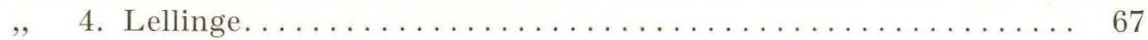

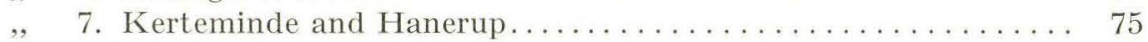

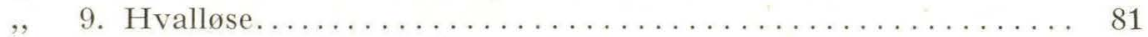

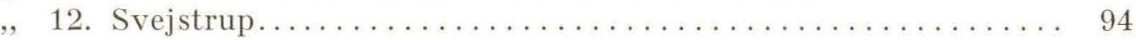

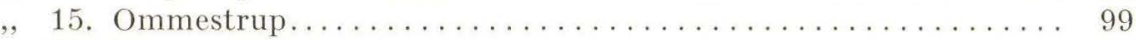

, 17. Rugaard........................... 108

Mechanical Analyses recalculated to UDDEN's Scale.

Table 2. Vestre Gasværk.......................... 41

, 5. Lellinge............................ 68

, 10. Hvalløse. ............................ 81

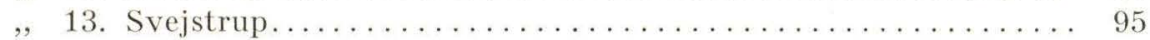

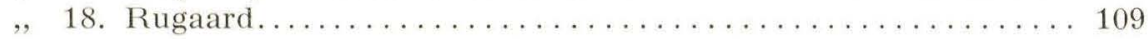

Quantitative Analyses.

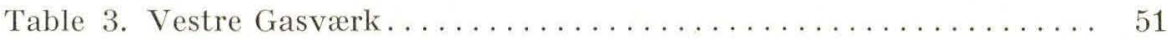

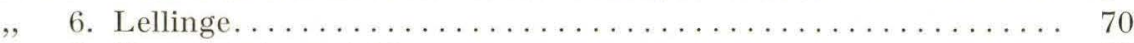

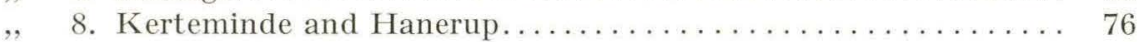

, 11. Hvalløse................................ 85

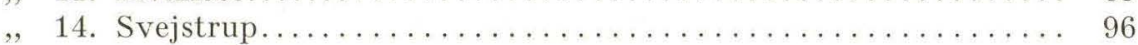

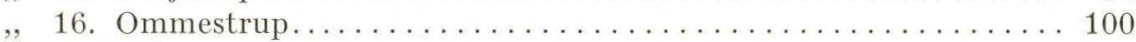

, 19. Rugaard............................ 110 


\section{List of Illustrations.}

1. Map of Denmark showing the distribution of the Paleocene and the localities described .............................. 8

2. Decantation cylinder.......................... 16

3. Map of the localities with Paleocene in Copenhagen.......... 19

4. Saltholm limestone, polished surface. South Harbour. Copenhagen. 24

5. Surface of greensand with derived fossils. Vestre Gasværk ...... 38

6. Clayey fine greensand. Vestre Gasværk................. 39

7. Sandy marl, intraformational conglomerate. Vestre Gasværk ..... 39

8. Mechanical composition of the rocks in the section at Vestre Gasværk,

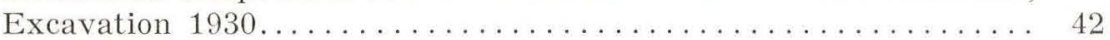

9. Mechanical composition of the rocks in the section at Vestre Gasværk,

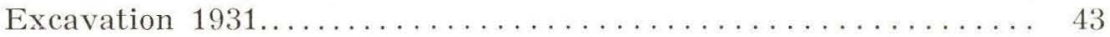

10. Distribution pyramids, Vestre Gasværk................. 44

11. Distribution curves, Vestre Gasværk................. 53

12. Sundkrogen. Calcium carbonate content of the samples........ 58

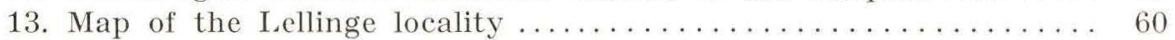

14. Distribution pyramids, Lellinge.................... 69

15. Distribution curves, Lellinge....................... 71

16. Sketch of the cliff at Lundsgaard................... 73

17. Map of the localities of Paleocene in Djursland ............. 79

18. Mechanical composition of the rocks in the section at Hvallose... 82

19. Distribution pyramids, Hvalløse................... 83

20. Distribution curves, Hvallose........................ 88

21. Mechanical composition of the rocks in the section at Svejstrup... 92

22. Distribution pyramids, Svejstrup.................. 93

23. Distribution curves, Svejstrup................... 97

24. Ommestrup. East wall of the pit................... 98

25. Distribution curves, Ommestrup.................... 102

26. Holme. Section showing calcium carbonate content and glauconite

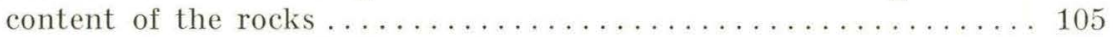

27. Distribution pyramid, Rugaard....................... 109

28. Distribution curves, Rugaard...................... 110

29. Borings showing Paleocene overlying Danian............. 136

30. Boring showing Paleocene overlying Danian .............. 137

31. Borings in Sealand, showing facies alternation............. 138

32. Borings showing relation between Paleocene and tuff-bearing series. 139 


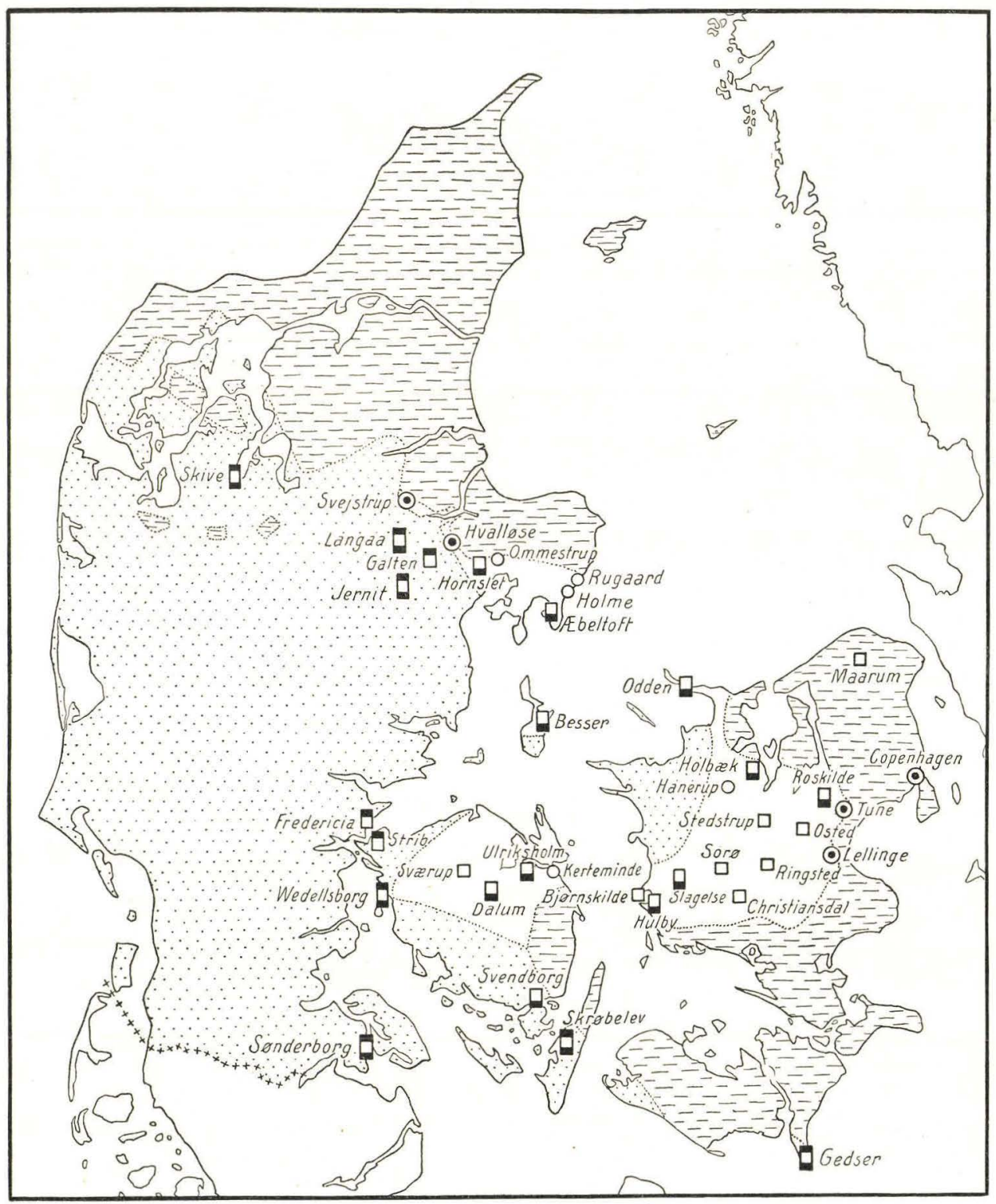

Fig. 1. Map of Denmark (1:2500000) showing the distribution of the Paleocene and the localities described. Broken lined area: Cretaceous; white area: Paleocene; stippled area: PreQuaternary deposits younger than Paleocene. $\odot$ Outcrops and excavations with Paleocene in situ (on the substratum). $\bigcirc$ Outcrops of Paleocene, disturbed and transported by ice. [ Borings with tuff-bearing series, Paleocene and Cretaceous. $\square$ Borings with tuff-bearing series and Paleocene. $\square$ Borings with Paleocene and Cretaceous. $\square$ Borings with $\mathrm{Pa}-$ leocene only. 


\section{Introduction.}

The rocks which are the subject of this work are those which are usually called Paleocene in Denmark. I admit that all opinions do not agree on the extent and the limits of the Paleocene; some authors, for instance Brünnich Nielsen (1919), Harder (1922) and Rosenkrantz (1924) include Danian in the Paleocene; Harder (1922), Mertz (1928) and Rosenkrantz (1924) consider that the Londinian with tuff-bearing diatomaceous earth (the so-called Moler i. e. Mo-clay) and the clay called Plastic clay belongs to the Paleocene, whereas ordinarily these strata are included in the Eocene ${ }^{1}$ ).

The series dealt with in the following comprises the Paleocene in the restricted sense, viz. the deposits overlying the limestones of the Danian, separated from it by a distinct unconformability, and underlying the tuff-bearing series ${ }^{2}$ ).

Whereas the lower boundary is easily recognizable stratigraphically, palaeontologically and petrographically, it is more difficult to fix the upper boundary, for both the upper parts of the Paleocene and the tuffbearing series are non-fossiliferous, or nearly so, in Denmark, and the border zones have been found only in borings. Consequently, on the model of O. B. Bøagild (1918) we must take the rocks as a means of distinguishing between Paleocene and Eocene. Fortunately we have an excellent "guide rock" in the tuff layers themselves; but as the thin subordinate tuff layers may be lost in boring samples taken at arbitrary depths, it is necessary to consider not only the tuff itself but also the rocks in which the tuff occurs. In the tuff-bearing series we find Mo-clay and metamorphosed Mo-clay, as well as grey Plastic clay and other dark clays which do not come in under the category of Plastic clay. These rocks, which alternate as facies-formations, can be distinguished petrographically from the Paleocene rocks. As a consequence, in the following I place to the Eocene all those rock types which occur as facies formations together with layers of volcanic tuff (regardless of whether tuff has been found in the samples or not), and to the Paleocene: the underlying rocks down to the Danian.

1) "Summary of the Geology of Denmark" (VICTOR MADSEN 1928) will give the Englishspeaking reader a short introduction in the Geology of Danmark and the terms made use of in this paper.

2) For this series Rosenkrantz has proposed the name of "Selandian" (1924). 


\section{A Survey of the Literature on the Paleocene.}

The earliest known deposits of those placed to the Paleocene in this work are the greensand deposits at Lellinge. They were found by FoncHHAMMER in 1842 and described by him a year later (ForCHHAMMER 1843). At first he supposed the greensand to be earlier in age than the White chalk (Senonian), but in a later paper he reckons with the greensand deposits as being later than the White chalk but earlier than Saltholm limestone $^{1}$ ) (Danian) (ForCHHAMMER 1849).

In the years that followed, other occurrences of greensand were discovered. During well-digging operations ForchHAMmer found greensand at Tune, about $8 \mathrm{~km} \mathrm{SE}$ of Roskilde (Forchнammer 1861, page 6), and at Vodroffsgaard Mill (now Vodroffsvej) in Copenhagen; we also know of boulders of greensand in Odsherred (Fовсннаммев 1843) and Gedser (ForchHAMmer 1861, page 9).

Forchinammer's dating of these greensand deposits was corrected by JoHxstRup, who in 1875 was responsible for a number of borings at Lellinge. It turned out that the greensand lay over the Saltholm limestone, and therefore he placed the Lellinge greensand to the uppermost part of the Cretaceous.

Earlier excavations at the Gasworks Vestre Gasværk in Copenhagen had already revealed a Tertiary fossiliferous series lying over limestone from the latest stage of the Cretaceous formation. Johnstrup placed it to the Tertiary, but older than all other occurrences of the Tertiary in Denmark (Johnstrup 1869); later on, Mørch (1874) placed the deposit to the Eocene on account of the fossils. In $1874-75$ when new excavations were being made at Vestre Gasværk a large fossil material was collected; it was treated by vox Koenen, who placed the occurrence to the Paleocene (VON KOENEN 1885).

In 1886 von KoENEN stated that the Lellinge greensand, which had been reckoned with as belonging to the upper part of the Cretaceous, must be closely related to the Vestre Gasværk series and therefore was Paleocene (Vox Koenen 1886, page 883); simultaneously the Belgian palaeontologists Pergens and Meunier gave expression to the same opinion, that this greensand belongs to the Paleocene (RAvN 1903 p. 36). Notwithstanding this, the greensand was generally placed to the Cretaceous. However, in 1898 Grönwall recalled von Konnen's opinion and supported it (GRönwaLL 1899).

In the nineties a special type of glauconitic limestone was found in several places in Copenhagen, especially during dredging operations in

$\left.{ }^{1}\right)$ By Saltholm limestone is to be understood compact, hardened limestone from the Danian. 
the harbour at "Larsens Plads". It was a fossil eonglomerate, and received the name of Crania limest one, because it contained many Crania tuberculata. As this conglomerate was found in contact with Saltholm limestone it was looked upon as the latter's upper layer. For palaeontological reasons Grönwall placed it to an upper zone of the Danian, "the zone with Crania tuberculata" together with petrographically differing rock types (GRöxwaLL 1899); but very soon the expression "Crania limestone" was used indiscriminately of all the rocks belonging to that zone. By means of Rosenkrantz's careful investigations into profiles with Crania limestone in the Copenhagen South Harbour the true relationship between these rocks was cleared up, for he showed that the hard glauconitic Crania limestone is the hardened lower part of the Paleocene greensand (Upper Crania limestone, greensand limestone), whereas the other rocks in GrönwALL's "zone with Crania tuberculata" are Cretaceous lime-sand deposits from the latest horizon of the Danian (Lower Crania limestone) (RosENKRANTZ 1920).

Round about the year 1890 the only Paleocene deposits known were greensand deposits (Lellinge, Vestre Gasværk); but in the nineties N. V. Ussing examined the marl at Kerteminde which had been discovered by JoHnstrup in 1886. By means of various boring sections Ussing showed that Kerteminde marl has a wide distribution in North Funen and in West Sealand, and that its place in the Tertiary series is between the Cretaceous and Eocene Plastic clay (Ussing 1899). Afterwards UsSING published a thorough petrographical description of the rock, and said that Kerteminde marl must have been deposited in rather deep water and in places where ocean currents did not have much influence (MADSEN 1902, pages 16-21). On the basis of fossils he had examined GröNWALL stated (MADSEN 1902, pages 21-24) that the dissimilarity between Kerteminde marl and greensand "may perhaps depend just as much upon facies differences as upon different ages", an idea which GRönwALL afterwards affirmed on several occasions (e. g. GRönWALL 19041 \& 2), although in a paper on the rich Paleocene fauna from the occurrence at Rugaard he assumes that "the main part of the Kerteminde marl is no doubt later than the Lellinge greensand" (GRönwaLL and HARder 1907). The same paper deals with the possibility that the youngest Paleocene consists of grey non-calcareous clay, as occurring in the cliff south of Rugaard. Almost at the same time Ussing came to the conclusion that the Mo-clay and the tuff-bearing strata are Eocene, and that the underlying grey, non-calcareous plastic clays must be Paleocene ${ }^{1}$ ) (Ussing 1907, page 192). It falls well in line with this that GRönwALL's description of a boring section at Besser, on the island of Samsø, shows that the greensand depos-

1) The author places the Plastic clay underlying the Mo-clay in the Limfjord district to the tuff-bearing series (Eocene). 
its and the Kerteminde marl are overlain by grey non-calcareous clay (GrönwaLl 1908). Grönwall likens this clay to the grey non-calcareous plastic clay underlying the Mo-clay and found overlying the Kerteminde marl in Northwest Sealand (Minthers 1907), and he draws up a schema according to which the Paleocene is divided into two groups, a lower group with "marly rocks, the lowest being glauconitic" (greensand and Kerteminde marl) and an upper group with "grey clay, partly shaly clay".

In 1918 O. B. BøGGILD wrote on the petrology and stratigraphy of the Paleocene, principally on the basis of deep borings (O. B. BøGGILD 1918). He distinguishes between three groups of Paleocene rocks: the sandy facies, the Kerteminde marl and the non-calcareous Paleocene, and demonstrates that for the most part they occur in the said order from below upwards, but that to some extent they must be regarded as faciesdeposits. He bases this on the strata sequence of the borings, where deposits of one type were found between deposits of another.

Nothing has since appeared to detract from the truth of these opinions, and the literature on Paleocene subjects has essentially confined itself to descriptions of new occurrences and discussions on the limits of the Paleocene and its relation to the Danian.

\section{Technique of Investigation.}

Different methods of investigation have been employed, all according to the various natures of the rocks.

The hard, cemented rocks have principally been examined in the form of thin sections under the microscope. In addition to the purely descriptive and mineralogical side of the investigation, great weight has been attached to the study of the inner structure and the lessons to be learned from the structure as to the age of the various secondary minerals, cementation, weathering etc.

The samples of more incoherent material such as sand, marl and clay have been subjected to a mechanical analysis by means of elutriation and sifting, whereafter the various fractions have been examined mineralogically, both qualitatively and quantitatively. The combination of the mechanical with the mineralogical quantitative analysis proved to be of great utility in understanding the loose sediments and particularly instructive with regard to circumstances connected with the transporting and sedimentation of the different clastic components.

Fractionating in the elutriation analyses was performed with the limits 
generally adopted in mechanical soil analysis in Europe, i. e. with the following fraction limits :

$0.02-0.05-0.1-0.2-0.5-1-2$ etc. (diameters in $\mathrm{mm}$ ).

The results of the mechanical analyses are given graphically in several ways.

In cases where there are samples from different parts of a section I have drawn a schematic section showing the percentual distribution of the different grain sizes in the various parts of the series. This provides us with an impression of the variations of the mechanical composition in the series; we can make direct readings of variations of gravel, sand and clay content, discontinuities in the series, and so on.

On the other hand, the more detailed analysis of the mechanical composition of the samples requires the recalculation of the analysis result in order to determine the position of the maximum grade, the lower or higher degree of sorting, and similar matters. By means of the cumulative curve the original analysis is so recalculated that the size limits of the fractions are made to form a quotient series with the quotient 2 (UDDEN's scale with the size limits . . 4-2-1-1/2-1/4 mm ... (UDDEN 1898)), and distribution pyramids have been drawn on the basis of the new percentages. The grain sizes are drawn on a logarithmic scale, and therefore the distances between the fractional limits become equal.

The various fractions have been mineralogically examined and the quantitative proportions between the most important rock-forming components have been calculated on the basis of a grain count ${ }^{1}$ ). The quantity of the lime grains, however, has generally been determined by chemical analysis of the calcium carbonate content ${ }^{2}$. Even if this involves some inaccuracy, as the lime grains do not always consist of pure calcium carbonate, there is no doubt that the counts display sufficiently well the tendency of the mineral distribution, and more than that can scarcely be required of the figures. As it is, the counts have provided useful information on the composition of the rock.

By means of a combination of these counts and the elutriation results I have calculated the distribution of the different components in the various grain sizes. The original elutriation analysis has so to say been dissolved in mechanical analyses of the different components. Comparisons between the distribution of the components, their maxima and sorting, in several cases have increased our knowledge of the structure of the rock. For the

1) The number of grains counted for each of the first three columns in the tables of quantitative analyses is as a rule from 500 to 1000 in each fraction.

${ }^{2}$ ) In the tables the asterisks indicate that the lime content has been found by counting the lime grains. 
purpose of illustrating these matters I have drawn distribution curves which indicate the distribution of the most important components.

Among the minerals in the rocks the secondary chemically newly-formed deserve special attention. In the Paleocene the minerals formed by chemical action in the sea-water are calcite, glauconite and pyrite. As pyrite is formed only in very reducing medium, but glauconite in more oxygenous medium, it is to be expected that the relation between glauconite and pyrite undergoes variations according to the changes in the composition of the sea-water and the physical conditions on the sea-floor. And in actual fact, among the rocks we find pronouncedly glauconitic types (greensand and glauconitic marl), pronouncedly pyritic types (for instance Kerteminde marl), and intermediate rocks.

The variation of the glauconite-pyrite ratio in the series has been examined in the boring samples. Whereas in most respects these samples are surprisingly similar, there are two aspects which vary considerably. One is the aforesaid ratio between glauconite and pyrite, the other is the calcium carbonate content. A third varying factor is the quantity of sandy components; but the different state of preservation of the samples and the different degree of silicification of the rocks make it an extremely difficult matter to determine their original consistence.

In order to secure a comparable material from different samples the glauconite-pyrite ratio has been determined for a certain grain size in all samples. I selected grains of a size of about $0.05 \mathrm{~mm}$, as this size is present in sufficient quantities in both the most sandy and the most clayey samples.

The results of the petrographical investigations of the boring samples are shown in diagrams of the boring sections, where the sand content is indicated by a stippling, the lime content and the glauconite-pyrite ratio by curves showing the percentages at the different depths.

\section{Analytical Technique.}

The method employed in the mechanical analysis was that grains exceeding $0.5 \mathrm{~mm}$ were separated by sifting and grains below that size by elutriation and sedimentation.

In calculating the settling times and the velocity of the water-flow in the elutriator I employed the theoretically calculated falling rates laid down by OsEen's formula, which states the constant velocity obtained by a spherical particle falling through a liquid:

$$
\mathrm{V}=\frac{\frac{-3 \eta}{\mathrm{r}} \pm \sqrt{\frac{9 \eta^{2}}{\mathrm{r}^{2}}+3 \mathrm{D}_{2}\left(\mathrm{D}_{1}-\mathrm{D}_{2}\right) \mathrm{gr}}}{\frac{9}{4} \mathrm{D}_{2}}
$$


where $V$ is the settling velocity of the particle (cm/sec.), $\mathrm{r}$ is the radius in $\mathrm{cm}, \eta$, the viscosity of the liquid, $\mathrm{D}_{1}$ the gravity of the particle, $\mathrm{D}_{2}$ the gravity of the liquid and $\mathrm{g}$ the gravitational acceleration (981). The gravity of quartz 2.65 was employed in the calculation.

About $50 \mathrm{~g}$ of sandy samples was used, of clayey samples 100 to $200 \mathrm{~g}$, as otherwise there would not be sufficient material of the coarser fractions for later examination. After weighing, the sample was subjected to a preliminary preparation, the object being to remove the mud and separate the sand grains. The sample was washed in distilled water and thoroughly brushed with a short-haired pencil in order to get the clay in suspension. At suitable intervals the muddy water was poured over into the decantation cylinder where the sand grains having a diameter greater than 0.02 $\mathrm{mm}$ subsided, whereas the water with the muddy matter was tapped off. Where brushing was insufficient to get the mud suspended in the water the sample had to be heated, sometimes boiled, in distilled water to which a small quantity of ammonia had been added. This preparation of the rock requires great care, and it is necessary to examine under the microscope whether the disaggregation is complete or not. Boiling and brushing must be repeated several times and the mud gradually removed.

As the decantation cylinders hitherto used have not been of the most suitable shape, I designed a cylinder for my experiments, the use of which has eliminated the sources of error as far as possible.

To be ideal a decantation cylinder must be so designed that 1) settling proceeds undisturbed, so that no currents form in the liquid and all the coarser particles fall to the bottom of the cylinder, 2) tapping is easy, without causing the settled particles to whirl up.

If requirement 1 is to be fulfilled the inner mouth of the drain pipe must turn downwards, otherwise material collects in the pipe during sedimentation. Point 2 requires that the inner mouth of the drain pipe should turn upwards. The use of a loose syphon is rather unpractical, so that a drain pipe in the bottom of the cylinder is preferable. The two decantation cylinders with a bottom drain most in use, ATtERBerg's and Appiani's, both have the disadvantage that eddies arise in the liquid when the cylinder is tapped.

The cylinder designed by the present writer consists of a glass cylinder with a lateral tube. The drain pipe is fastened in a rubber stopper so that it can be turned and pushed in and out. When filling with water the inner mouth of the pipe is downwards and it is drawn out as far as possible. The cylinder is first filled from the top, then shaken to suspend the grains. Then the drain pipe is connected with the jar of distilled water and the remaining quantity of water is fed to the cylinder from below. This sends the grains upwards (effecting a quicker separation) and the liquid comes to rest as soon as the cylinder is full. During the settling the drain pipe 
is out to its full extent and therefore cannot interfere (Fig. 2 A). To tap the water off, the inner mouth of the pipe is pushed to the middle of the cylinder and turned upwards, so that the operation essentially affects the water above the pipe (Fig. $2 \mathrm{~B}$ ). The sedimentation process is repeated till the liquid is clear after the expiry of the time corresponding to the fall of the grains at the particular temperature and column height. As the quantity of mud is determined by difference it is not collected.

When the disaggregation is complete and all grains under $0.02 \mathrm{~mm}$ in diameter have been removed, the sample is ready for elutriation. This

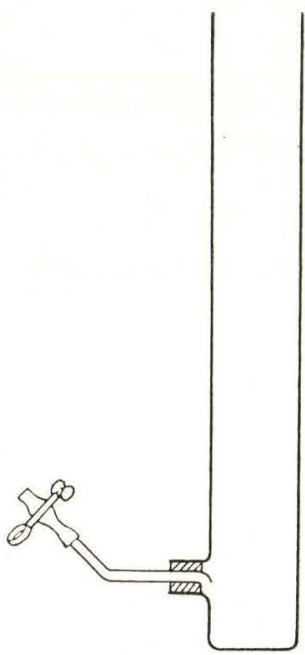

A

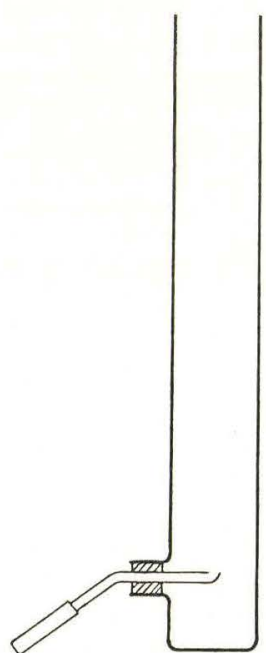

B

Fig. 2. Decantation cylinder, A) during settling B) during tapping. proceeds in a single-vessel elutriator, so that the various fractions are washed out with different velocities of the rising stream of water. The vessel used is OrtH's, which is of the best shape when it is required to avoid whirling movements in the ascending water stream. A calibrated piezometer tube is employed to control the correctness of the velocity.

The coarsest fraction that can be separated in ORTH's vessel is $0.1-0.2 \mathrm{~mm}$. The larger particles are dried and then sifted in plate sieves with circular holes. If the original sample contains gravel particles, a separate determination is made of them by weighing a good-sized sample, whereafter grains of more than $1 \mathrm{~mm}$ are separated out by sifting. For elutriation analysis of such samples the rock is used after grains over $2 \mathrm{~mm}$ have been removed. When this overlapping is employed we have all grains over $1 \mathrm{~mm}$ determined by sifting and all under $1 \mathrm{~mm}$ by elutriation analysis followed by sifting, and the percentages are easy to calculate.

\section{Summary of Paleocene Occurrences in Denmark.}

The Paleocene deposits now occurring in Denmark are only a slight remnant of the original deposits. There is scarcely any doubt that there 
have been fairly pronounced tectonic movements during the course of the Tertiary period after the conclusion of the Paleocene, and afterwards, by the planing of the ice in the Glacial Age, the Paleocene deposits have been eroded over wide areas and only preserved where they have lain in positions sufficiently well protected. As it is only in few places that Paleocene deposits are visible, it is mostly from information derived from borings that we have our impression of the present distribution of the Paleocene in Denmark (see the map, Fig. 1, p. 8).

In the east part of Sealand the ice eroded almost all the Tertiary away, so that much the greater part of the substratum consists of Cretaceous, especially Danian; in restricted areas, however, governed presumably by tectonic conditions, the Paleocene still remains in patches. The most important of these is the Copenhagen area, where in several places the lower parts of the Paleocene deposits have been found, resting upon the Danian. There the series begins with greensand deposits, over which is dark, sandy marl. In Northeast Sealand similar Paleocene deposits have been discovered by a single boring at Maarum.

In Mid-Sealand is a region where a very large number of borings have revealed the Paleocene immediately under the Quaternary deposits. In the east part of this region there are mostly greensand beds with a thickness of at least 50 metres; more to the west, however, the thickness of the greensand decreases, whereas we find Paleocene marl in very great thickness (at least 110 metres). On the extreme northwest the Paleocene deposits are overlain by Eocene Plastic clay.

In this large Mid-Sealand region there is only one visible occurrence, viz. that at Lellinge, where the river Køge Aa has cut down into the greensand. In the form of dislocated glacial blocks there are outcrops of marl at Hanerup near Holbæk and in the district round Lejre (SIGURD HANSEN 1930).

On the islands south of Sealand, where the substratum for much the greater part consists of White chalk, the Paleocene has been revealed by a boring at Gedser.

On the island of Funen the Paleocene mostly consists of light marl, which borings have revealed directly under the Quaternary over the greater part of Mid-Funen; more to the west, and on the island of Langeland, a few borings have revealed the Paleocene under the Eocene deposits.

The light marl is exposed in Lundsgaard Cliff at Kerteminde. This occurrence, which has given Paleocene marl the name of Kerteminde marl, is presumably a dislocated block carried there by the ice (Fig. 16, p. 73).

On the island of Samsø the Paleocene is best known from a boring at Besser, where non-calcareous Paleocene clay is the upper part of the formation. 
In Jutland the Paleocene occurs exposed in an area extending from the south part of Djursland to the district northwest of Randers (Fig. 17, p. 79). Northeast of it is Danian, southwest of it Oligocene. At Randers there are two visible occurrences, at Hvalløse and Svejstrup, where the basal deposit of the Paleocene can be seen overlying the Danian. Much the greater part of the rocks is marl, only the very lowest being rather sandy. In Djursland are quite a number of exposed occurrences with Paleocene marl. The bedding is almost always disturbed, and this, combined with the fact that the localities lie just inside a pronounced marginal moraine, indicates most decidedly that here the Paleocene deposits have been transported by the ice. Nevertheless, as borings show the substratum also consists of Paleocene marl. At Rugaard in addition to marl deposits there is non-calcareous clay in the cliffs.

Outside of the Randers-Djursland region only few borings have revealed the Paleocene in Jutland, and only in Mid and East Jutland. Everywhere it lies at great depths, overlain by late Tertiary and Quaternary deposits.

\section{Localities in Sealand where Greensand Predominates.}

In this chapter a description will be given of the outcrops and excavations with typical greensand deposits, viz. Copenhagen, Lellinge and Tune.

\section{The Copenhagen Area. Summary of Localities.}

According to Rosenkrantz, it is possible to distinguish between three regions in the Copenhagen underground, divided by fault lines. Through Frederiksberg and Valby trends a fault line from north to south, to the west of which there is old bryozoan limestone. East of the line are two regions, one to the south with young bryozoan limestone and one to the north in which the underground consists of lime-sand or lime-sand in its hardened form (Saltholm limestone, Lower Crania limestone). The limesand region and the region of young bryozoan limestone are separated by a fault line trending from the park Frederiksberg Have in an almost southeasterly direction.

Paleocene deposits in situ in Copenhagen have been found in twelve (possibly thirteen) places, all within the lime-sand region, so that every- 
where the substratum of the Paleocene is lime-sand or Saltholm limestone. The series approaches 7 metres in thickness.

The Paleocene series begins with a basal conglomerate, consisting to a great extent of more or less rolled fragments of Cretaceous fossils. Over it follows calcareous greensand and arenaceous dark-grey marl. The

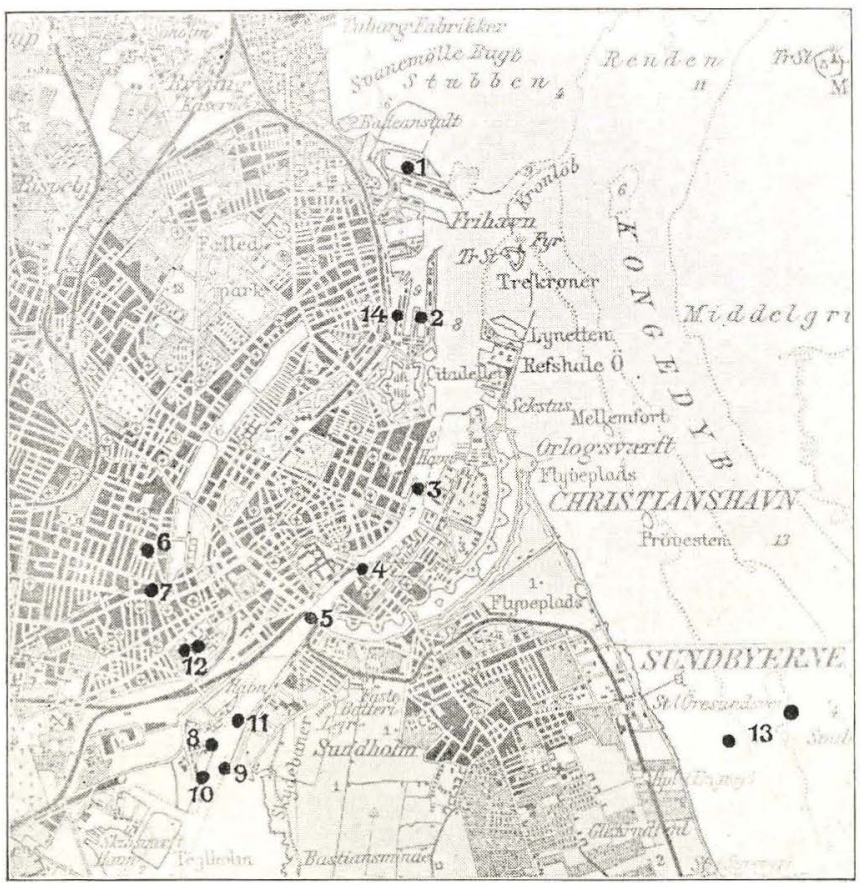

Fig. 3. Map of the localities with Paleocene in Copenhagen (1:100000). 1 Sundkrogen; 2 Free Port; 3 Larsens Plads; 4 Knippelsbro; 5 Langebro; 6 Vodroffsvej; 7 Gamle Kongevej; 8 Enghave Brygge; 9 South Harbour Excavation II; 10 South Harbour Excavation I; 11 Islands Brygge: 12 Vestre Gasværk; 13 Kongedybet; 14 Nordisk Fjerfabrik.

lowest part of the series is usually considerably cemented by calcite and thus forms a hard glauconitic limestone: Greensand limestone (Upper Crania limestone).

The localities are as follows:

1. Sundkrogen. The series was found when deepening the harbour basin of Sundkrogen and has been described by HARDER (1922) and RosENKRANTZ (1924). Excavations and borings revealed the following section:

About 2.8 metres of dark marl, more sandy below.

About 2.5 metres of rather coarse greensand.

About 0.8 metre of greensand limestone.

Saltholm limestone. 
2. Free Port. According to RosenkJar (1895) about 1.9 metres of greensand deposits rest upon limestone.

3. Larsens Plads. When dredging in the harbour basin in 1890 glauconitic limestone, "Upper Crania limestone" was found, to some degree developed as a conglomerate, overlying Saltholm limestone. The Crania limestone from there was described by RørDam under the name of "spongia limestone" (RøRdau 1897).

4. Knippelsbro. Small portions of greensand limestone were found by Brünnich Nielsen in cavities in the surface of the Saltholm limestone (BrüNnich Nielsen 1910).

5. Langebro. Rosenkrantz, who includes this locality on his last map of Copenhagen's underground (1934), has kindly informed me that conditions here are the same as at Knippelsbro.

6. Vodroffsvej. The locality was discovered by Forchнамmer 1864 and examined by JoHnstrup 1873. About half a metre of almost unconsolidated greensand overlies almost unconsolidated lime-sand from the Danian.

7. Gammel Kongevej 33. In the course of well-digging about half a metre of greensand was found, consisting of coarse and fine layers. The substratum was not seen.

8. Enghave Brygge. Rosenkrantz has recorded $30 \mathrm{~cm}$ of greensand limestone, of which the lower $5-8 \mathrm{~cm}$ consists of shelly conglomerate. The Paleocene overlies Saltholm limestone with flints (Rosenkrantz 1924).

9. South Harbour Excavation II. Rosenkrantz describes at length two localities in the South Harbour. In Excavation II, where the Paleocene is best preserved, there is about $25 \mathrm{~cm}$ of greensand limestone, the lower $10 \mathrm{~cm}$ or so being developed as a shelly conglomerate and containing pebbles of Saltholm limestone. The substratum is Saltholm limestone (Rosenkrantz 1920).

10. South Harbour Excavation I. Revealed greensand limestone of the same type as Excavation II, but not so thick. The substratum is Saltholm limestone.

11. Islands Brygge. When making excavations for a trench for cables in 1931 large quantities of blocks of Saltholm limestone and greensand limestone were removed opposite the street Drechselsgade. The surface of the limestone lies 9 metres below the mean water level.

When I examined the locality I found a number of large blocks which showed that the consolidated part of the Paleocene here had a thickness of at least $65 \mathrm{~cm}$. One block had about $10 \mathrm{~cm}$ of shelly conglomerate in contact with Saltholm limestone. Another had about $25 \mathrm{~cm}$ of greensand limestone, over which was a sharp boundary and an upper conglomerate layer about $10 \mathrm{~cm}$ thick, the lower part of which was coarse. In this block 
was a lens of entirely unconsolidated greensand, about $8 \mathrm{~cm}$ at the thickest part. This lens was found almost at the boundary between the greensand limestone and the conglomerate. A third block showed that overlying the upper conglomerate was at least $20 \mathrm{~cm}$ of greensand limestone. In both conglomerates there were pebbles of Saltholm limestone.

12. Vestre Gasværk. In 1930 and 1931 excavations were made in the known localities at the Gasworks Vestre Gasværk. In 1930 a section was dug in JoHnstrup's 1868 locality, and in 1931 about 200 metres more to the northeast, in Johnstrup's 1874 locality. Both excavations yielded excellent rock samples. A combination of the two gives the following series:

About 2.6 metres of dark sandy marl

About 0.6 metre of fine, clayey greensand

About 3.0 metres of coarser greensand

About 0.4 metre of greensand limestone.

Saltholm limestone.

In addition to these 12 localities, where the Paleocene definitely is in situ, Paleocene rocks are found at the following places:

13. Konged y bet. During dredgings in 1935 dark sandy marl of a type similar to that from Vestre Gasværk was found at two places off the street Italiensvej, viz. about 600 metres and about 1300 metres from the shore. Farthest west there seems to be a hard bed of more sandy character, about $8 \mathrm{~cm}$ thick, over the sandy marl.

14. At Nordisk Fjerfabrik (Feather Works) in the Free Port, there are boulders of greensand limestone and shelly conglomerate as a local moraine.

15. In South Harbour Excavation I there were boulders from local moraine. These boulders, which have previously been described by Rosenkrastz, have greensand limestone overlying an especially coarse-grained type of Saltholm limestone (Rosenkrantz 1924).

In addition, several places in the moraine have yielded various types of Paleocene marly limestone (GRönwalL 1897). The types are not quite the same as those otherwise occurring in the Copenhagen underground, and it must be assumed that they have been carried a good distance by the ice. As their native place is unknown, these boulders have not been included in the present work. 


\section{Earlier Petrographical Investigations.}

Although there is a quantity of literature on the series of the Copenhagen Paleocene and their stratigraphical position, only few works have gone deeply into the petrology of the rocks.

The shelly conglomerate from Larsens Plads was described by RøRDAM (1897) under the name of spongia limestone. It is described as a zoogenous limestone with conglomerate structure, consisting of a quantity of different animal remains (foraminifera, bryozoa, Serpula, Crania and other brachiopods and echinoderm remains). These shells are cemented together by clear calcite, but in such a manner that in the interstices between the shells lie numerous sponge remains which permeate all the spaces like a dense network. As these sponge remains are very green, they give the stone a characteristic greyish-green colour.

In the same work RøRDAM mentions the greensand from Vodroffsvej, and, based upon a chemical analysis, shows that it is closely related to the greensand of Lellinge. He also states that it contains small phosphorites about a millimetre in size. The phosphorites are described later by GrönwalL, also from Larsens Plads (1899). As they contain organic remains besides phosphorite and calcite, GRöNWALL interprets them as coproliths.

In 1920 Rosenkrantz describes the greensand limestone from the South Harbour, with its lowest conglomeratic horizon, under the name of Upper Crania limestone. The rock is described as a conglomerate of fossils. These are cemented together by a marly rock which has a greenish gleam on account of its glauconite content. Upwards the fossils become more and more rare and the rock passes into a marly limestone, to a certain degree resembling the rocks at Lellinge.

Otherwise in his papers RosenkRANTz touches only briefly upon petrographical matters. Still, it is of importance that he draws attention to the unconformity between the Danian lime-sand and the Paleocene deposits, and points out that the lime sand in the greensand deposits comes from disintegrated Danian lime-sand. As the depth of the Paleocene sea increased and the supply of disintegrated limestone ceased, the deposition changed character, the lime content falling off and the allochthonous, terrigenous intermixture becoming more and more predominant (RosENKRANTZ 1920, 1924, 1930).

In his work on the pre-Quaternary sedimentary rocks of Sweden, HADDing (1932) describes the glauconite impregnation of the fossil fragments and the pebbles of the Upper Crania limestone from the South Harbour. According to HADDING the coproliths in the rocks lie in a secondary site of deposition. (1932, p. 110). 


\section{Petrographic Description of Rocks from Localities with Hardened Paleocene.}

The Substratum.

In the various localities the substratum to the Paleocene differs somewhat in character. Apart from the Vodroffsvej occurrence, which shall be deseribed later, the substratum consists of a hard grey limestone, Saltholm limestone.

Saltholm limestone at Copenhagen is built up of fine or coarse calcareous sand, consisting of foraminiferal and bryozoan fragments and other lime fragments of sand-grain size, sub-angular or rounded, cemented by a fine or coarse calcite aggregate.

The microscope reveals that the rock sometimes is fine-grained and with a cement of a fine calcite aggregate, sometimes coarse-grained and with coarse-grained cement. In places, however, we find transitions between these types. The coarsest rocks presumably are the youngest (see page 25 ).

The finest-grained type occurs in the area of the South Harbour; the rock is pronouncedly grey in colour with a more or less brownish tint, visible especially when the rock is moist. The rock is not stratified nor has it any other exterior structural signs. Nevertheless, in the limestone from Islands Brygge there is sometimes a peculiar vein or stripe, observable particularly when a surface is polished (Fig. 4). The lines appear lighter or darker than their surroundings, they run irregularly, and sometimes ramify and connect with one another. Macroscopically it looks like an irregular stratification, in which the layers are from 5 to $10 \mathrm{~mm}$ thick, but microscopic examination reveals that the vein is the result of differences in the nature of the cement.

Under the microscope the rock appears as a fine-grained lime-sandstone, built up of shell fragments of various kinds and cemented by a finegrained calcite aggregate. The rock accords fairly well with RøRDAM's description of foraminiferal limestone.

The great majority of the sandy components are calcareous. In the slides, shells of foraminifera are especially conspicious and easily recognisable, often whole and in a good state of preservation and forming a large part of the rock. In most cases the other lime sand components appear in the section as grains of irregular shape or more or less rounded. Sometimes they are built up of transversal prisms, or they have a thready or scaly structure, so that it is possible to recognise an organic structure, though it is not always possible to place the shell fragments to any definite group of organisms. However, a comparison with other limestones makes it probable that many of these shells are fragments of bryozoa. Sometimes the bryozoan fragments as a whole extinguish under crossed nicols, 
but in most cases only part of the shell is extinct and, on turning the stage, the extinct portion travels more or less irregularly from place to place. The grains of the lime-sand are fairly uniform in size, varying between 0.10 and $0.15 \mathrm{~mm}$. Thus in the samples examined the calcareous sand consists mostly of foraminifera and bryozoa. Whereas to some extent the foraminifera may have been alive at the time of deposition, the crushed state and the uniformity in grain size of the bryozoan fragments necessitate the assumption that these are a really clastic component, i. e. originate from older deposits of bryozoan limestone

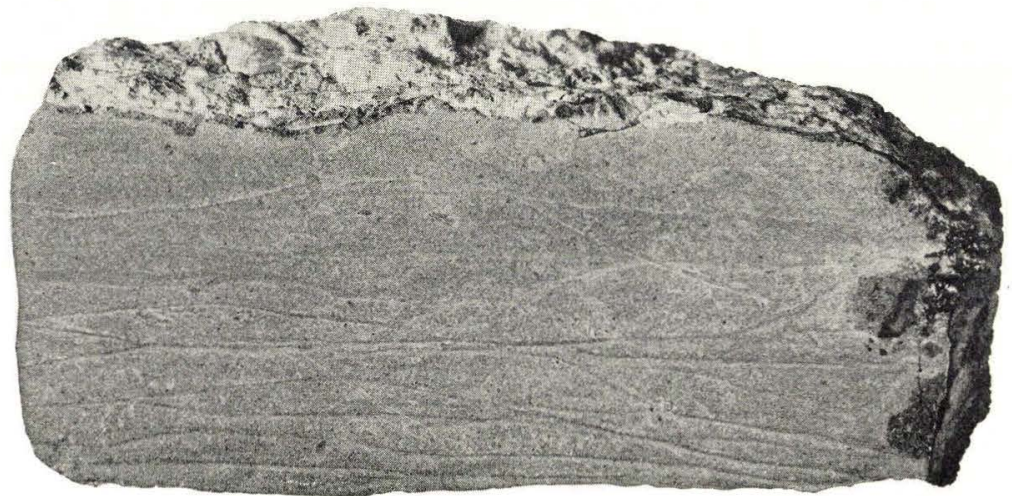

Fig. 4. Polished surface of Saltholm limestone and Paleocene shelly conglomerate, at right angles to the bedding surface. South Harbour. Copenhagen. (Nat. size).

which has been broken down, whereafter the calcareous sand has been transported to the place where the rock was deposited.

Besides calcareous grains there is a very small quantity of quartz grains and felspar grains, isodiametric, mostly angular. The grain size is slightly less than that of the lime grains.

Whereas the rock is quite devoid of glauconite, pyrite occurs in varying quantities scattered about in the rock, mostly as extremely fine grains. It occurs in the cavities of foraminifera and as pigment or impregnation in the lime grains, but not in the cement.

The cement is a fine calcareous aggregate, in which the calcite is quite pure. The veining observed in some of the samples turns out to be the result of varying crystal sizes in the cement, the lightest parts containing the coarsest cement, whereas the darker stripes form where the aggregate is so fine that it is barely possible to distinguish the individual crystals.

Other samples of Saltholm limestone from Copenhagen are not quite the same. Under the Paleocene at Larsens Plads there is a limestone of much coarser structure. The foraminifera are not so prominent and the 
majority of the sand grains consist of rounded lime grains whose structure cannot be exactly determined. These grains, which are grey in colour, are mostly built up of a single crystal of calcite. As a rule they are strongly pigmented by fine grains of pyrite and therefore stand out well against the cement. This cement is coarser than in the aforementioned type and is quite transparent. The lime grains are often in optical continuity with the adjoining parts of the cementing calcite, which shows that the latter has been formed by the continued growth of the lime grains.

This type conforms in every way with the Saltholm limestone from Østre Gasværk, which RøRDAm has described as foraminiferal limestone (RoRDAm 1897). He overlooked the fact, however, that the greater part of the lime grains are impure clastic grains.

The coarsest type of Saltholm limestone forms the substratum to the Paleocene in the blocks in the local moraine found in South Harbour Excavation I. There the limestone occurs as a grey shelly limestone, which passes into a medium-grained grey limestone.

The rocks consist of rolled and well-rounded shells and shell fragments which are markedly pigmented by pyrite. As a rule, the lime grains consist of a single calcite crystal. They lie in a mosaic of quite clear calcite cement, which often has grown out so that the cement and the adjacent shell fragment form an optical unity. The grain size is mostly round about $0.2-0.3 \mathrm{~mm}$.

Besides lime grains there are oval coproliths of the same type as in the Paleocene (see later) and a few quartz grains. Pyrite is present in large quantities in the form of a fine pigment in the shell fragments, but never in the cement. There is also a small quantity of glauconite, especially as scattered round or lobate grains. These grains are of the same size as the lime grains. Glauconite is also found very subordinately in the form of pigment in the lime grains.

Scarcely any doubt can be entertained that this type of limestone is the youngest of the lime-sand deposits. This is argued by its character of a shallow-water sediment and its glauconite content, and also by the fact that much the greater number of limestone pebbles occurring in the Paleocene basal conglomerate are of this type. It is probable, as RosExKRANTZ also suggests, that the many derived fossils found in the bottom stratum of the Paleocene originate in this rock. It is another matter that the fossils in the shelly limestone are also partly washed together, as is evidenced by their occurrence in a separate layer and by their rolled nature.

Coarse grained lime-sand deposits such as those now described are not confined to this small Copenhagen area. At Aashøj, near Køge, there are rocks essentially agreeing with the Copenhagen lime-sand, being composed of lime sand cemented by a coarse calcite mosaic and containing a few 
rounded and lobate glauconite grains and a little pigmentary glauconite in some of the lime grains.

\section{The Paleocene Boundary against the Substratum.}

This boundary has previously been described by Rosenkrantz, who was the first to recognise its character of an abrasion plane.

The surface of the substratum is rather unevenly undulating. In it are numerous cavities and holes presumably produced by boring organisms, and afterwards filled with Paleocene material. Sometimes there is a flint bed just below the boundary. In such cases the boundary plane is somewhat irregular and the greensand limestone goes down into cavities and channels in the flint, but is separated from it by a thin layer of silicified Saltholm limestone. This shows that the flint was formed when the Paleocene sea broke in over the Danian deposits. (Rosenkrantz 1924). The Danian lime-sand has partly been hardened before the greensand was deposited, for RosenkRantz has observed crevices in the Saltholm limestone filled with crystalline calcite extending up to the boundary against the Paleocene (1924).

The varying nature of the substratum in the different localities leads to the assumption that the strata which were broken up and rebedded at the beginning of the Paleocene were very thick.

\section{The Consolidated Rock-Types of the Paleocene.}

As has been stated, the lower parts of the Paleocene are hardened into a hard grey-green limestone (Upper Crania limestone, greensand limestone), the thickness of which is up to $0.65 \mathrm{~m}$. The lower $10 \mathrm{~cm}$ or so are often developed as a shelly conglomerate built up of rolled Danian fossils, whereas the rest is hardened greensand. At Islands Brygge we also know of an upper conglomerate of exactly the same structure as the basal conglomerate. The rocks from the various localities display only slight variations, and, as there is an abundance of material from the South Harbour, the rocks from there are treated in the following as type-rocks, after which are described the smaller variants and special features found in the rocks from the other localities.

The shelly conglomerate. The shelly conglomerate is a hard limestone, built up of more or less rolled, glauconitized Danian fossils, glauconitized lime sand particles and glauconite grains, all cemented by coarse crystalline calcite. The calcium carbonate content is about $94 \%$. Pebbles of limestone are present, but very subordinately.

Macroscopically the shelly conglomerate is a hard grey-green limestone, in which are embedded numerous more or less rolled Danian fossils, Crania, Terebratula, fragments of crinoids and other echinoderm remains, 
etc. The greater part of these shells are coloured grey-green; more rarely they have their original white or pale yellow colour. The matrix is greyish, fine-grained. Sometimes the rock contains bright, brown or black ellipsoidal phosphorites, about $0.5-1.5 \mathrm{~mm}$ long and $0.2-0.5 \mathrm{~mm}$ in cross-section. GRöNWALL described them as coproliths. On some samples there are green bedding surfaces formed of a fine glauconite powder. Similar green surfaces with glauconite powder are also to be seen at places where large Paleocene mussels have lain, the original calcareous substance having partly or entirely disappeared and been replaced by glauconite. The pebbles are grey and greenish limestone, their surface sometimes glauconitized, sometimes not. As a rule the pebbles measure between 5 and $10 \mathrm{~cm}$ in diameter. The quantity of limestone pebbles is so small that they do not justify calling the rock a conglomerate; but as the shells occur as clastic, rolled and transported components, the term "shelly conglomerate" is warrantable.

Microscopic examination shows that the clastic components occur especially in two distinct sizes, there being a rather wide gap between the size of the rolled shells and that of the lime sand grains.

The gravel particles (and the coarsest sand grains) consist exclusively of rolled organisms and of phosphorites. Very numerous are echinoderm fragments, which are easy to recognize, as every fragment is a single crystal, in which one can see a network of more compact and more porous areas. All the shell fragments are pronouncedly glauconitized in a peculiar manner: the glauconite has permeated all the fine pores and moreover partly replaced the calcite, so that, all according to the structure of the shell, it has formed trelliswork, rods, and distorted, branchy forms of glauconite. It is clearly to be seen how in the Terebratula and Crania shells the glauconite has made its way into the large pores extending from the surface of the shells transversally across them (Plate 1 Fig. 1). In the echinoderm shells continued glauconitization has formed a complete network, in which the various glauconite rods are mutually connected. As the glauconitization proceeds at the expense of the calcite the originally separate glauconite parts merge together and form larger, compact masses which continue in the aforesaid network. Sometimes the glauconitization is more pronounced at the edges, but most frequently it is evenly distributed over the whole shell.

Besides the aforesaid form of glauconitization, which consists partly in a filling of pores, or impregnation, partly in a deposition of glauconite at the expense of the calcite, we find compact fillings of glauconite in irregular cavities extending into the shell from the surface. The shape of these cavities indicates that they are bore holes, probably made by sponges.

The diameter of the sand grains is mostly about $0.2 \mathrm{~mm}$, a size that is very constant in both the finer and the coarser parts of the conglomerates, just as it is the prevailing grain size in the ordinary greensand lime- 
stone. The sand grains are partly foraminifera and bryozoan shell fragments, partly well-rounded calcareous grains of other origin. Each one is formed of a single calcite crystal, but is certainly of organic origin. The sandy particles appear impure, greyish-brown in colour, in contrast to the cement. The sand is accordingly of the same nature and size as that which forms the Danian lime-sand, which is distinct evidence that the sandy particles in fact have come from there. As the free, unchanged lime grains occur in large quantities in the Paleocene, the Danian lime-sand can have been only little hardened at the beginning of the Paleocene period.

There are only very few allochthonous-clastic components. The greater part are quartz, but a few felspar grains have been found, as well as small fragments of quartzite. The grain size of these components is mostly about $0.4-0.5 \mathrm{~mm}$. The grains are always very rounded and mostly pure, but sometimes we find glauconite impregnations in fine cracks in the grains.

Besides as a pigment or impregnation, glauconite occurs as round or lobate grains of the same type as in the present day is formed in the greensand deposits. The quantity varies considerably. As a rule they are not particularly common in the basal conglomerate, but much more common in the upper conglomerate at Islands Brygge. Generally the size of the glauconite grains is about $0.2 \mathrm{~mm}$, i. e. the same size as the lime grains. As will be shown later, it is possible on some of the Paleocene rocks to see definitely that the glauconite grains have been transported, whereas the pigmentary glauconite is autochthonous.

The earthy glauconite, which forms the green coating on the limestone pebbles and the glauconite from green bedding surfaces, consists of a fine aggregate of glauconite without any particular structure. On the other hand the glauconite in places where a mussel shell has lain, has its own structure, consisting of very uniform, small, straight rods about $0.01 \mathrm{~mm}$ wide and $0.05 \mathrm{~mm}$ long. There is scarcely any doubt that this is a pseudomorph on the prism layer in the shell.

Pyrite occurs in small quantities as a pigment or as small concretionary masses in the shell fragments and in the lime grains. Like the glauconite, it has deposited itself especially in pores and small cavities. A very small quantity of pyrite is also to be found between the calcite crystals of the cement, apparently forced aside by their growth.

Most frequently the coproliths are long, ellipsoidal, more rarely spherical, with a smooth, shiny surface. The microscope does not reveal much of their actual structure. They consist of a light or dark brown isotropic phosphoritic mass, which may be more or less glauconitized by pigmentary glauconite or pyritized by fine grains of pyrite. Of foreign bodies they may contain quartz and tiny calcareous grains. 
The cement consists of pure and clear calcite, which forms a coarse, marbled mosaic. The calcite has often grown out from the shell particles, so that the new calcite is in optical continuity with the adjoining parts of the calcareous grains. The cementing must have taken place while the glauconite was soft and yielding, for it is often seen that small secondary calcite crystals have penetrated into a glauconite mass and have forced the glauconite aside. This circumstance supports the theory that glauconite is formed as a gel.

The greensand limestone. The greensand limestone is a hard limestone, built up of lime sand and glauconite grains and a few quartz grains like the shelly conglomerate and glauconitized and cemented in the same way. The calcium carbonate content is about $90-92 \%$.

The structure of the greensand limestone agrees in every way with that of the shelly conglomerate, except that the coarsest components are missing. Thus greensand limestone is a true arenaceous rock, in which the sand grains for the greater part are lime grains of organic origin. These lime grains are glauconitized and sometimes pyritized too, exactly as in the conglomerate. There is a rather larger number of glauconite grains in the greensand limestone than in the basal conglomerate. They are dark green, spherical or lobate grains of the same size as the lime grains, i. e. about $0.2 \mathrm{~mm}$ in diameter. Among the lime grains there is quite a number of particularly well-preserved foraminifera which may have lived in the Paleocene sea and therefore should possibly be regarded more as a biogenous than as a clastic component. And as usual there is a very small quantity of quartz and felspar, very exceptionally some coproliths of phosphorite.

\section{The Rocks at Larsens Plads.}

Most of the samples from Larsens Plads diverge from the main type in that the glauconitizing is not so far advanced. This is true especially of those samples which show a rather fine-grained greensand limestone in contact with Saltholm limestone. Sometimes, in fact, it is very difficult to show where the greensand limestone begins and the Saltholm limestone ceases. The sandy components are of exactly the same size and character in both rocks, they are smaller than in the other localities, viz. about $0.1-0.15 \mathrm{~mm}$, and foraminifera form a relatively large part of this grain size.

The samples consisting of a pronouncedly shelly conglomerate are more normally developed, but with relatively little glauconite and much pyrite.

Some of the samples display peculiar cementation features (Plate 1 Fig. 2). The rolled fossils are surrounded by an oolitic zone of calcite which has a fine fibrous structure, the fibres standing out almost at rightangles from the fossils. The colour of this crust is dull opal-white in reflec- 
ted light, whereas in transmitted light and with one nicol it is yellowish, with varying absorption in different directions. The crust, which is about $0.04 \mathrm{~mm}$ thick, may surround several grains as one whole and thus rather coats the walls in the interstices between the fossils and sand grains than the fossils themselves. Examination with crossed nicols shows that the crust extinguishes in fragments together with the shell substance inside it. Where there are larger interstices the zone may continue into them, forming stalactitic masses.

The calcareous skin must doubtless be taken to be an oolitic structure, though ovoids proper have not been formed. Oolitic skins in limestone have often been described previously (for instance HoLTEDAHL 1918, LougHLIN 1929) but the feature seems not to be quite the same as in the shelly conglomerate, where the skin coats the interstices between the lime grains, not the lime grains themselves.

Outside the oolitic calcite coatings there is in some places a zone of sphaerulitic chalcedony, either in the form of scattered, adhering semisphaerulites or as a complete band formed by the coalition of sphaerulites. As a rule this band is 0.03 to $0.04 \mathrm{~mm}$ wide, but smaller cavities may also be entirely filled with sphaerulitic chalcedony.

The remainder of the interstices are infilled with the ordinary clear calcareous cement. Along the seams between the calcite crystals of the cement one sometimes finds fine grains of pyrite, which is also the most frequently occurring chemical precipitation in the pores of the fossils, whereas pigmentary glauconite is more rare. Otherwise the rock is a normal shelly conglomerate with a few glauconite and quartz grains and coproliths.

Features in the rocks at Larsens Plads show that the oolitic zone must have been formed immediately after the deposition of the clastic calcareous grains, which must also be the case if the oolitic phenomena, as generally assumed, are chemical precipitations caused by organic biochemical activity. The last process in the rock - after the deposition of the chalcedony zone - has been the cementation. During the formation of the calcareous cement a small quantity of fine grains of pyrite from the interstices between the grains has been forced aside by the growing crystals, so that they now lie in the seams between the calcite crystals of the cement.

\section{The Blocks from the Local Moraine at Nordisk Fjerfabrik.}

Some of the blocks from Nordisk Fjerfabrik display pyritizing to a high degree (Plate 1 Fig. 3). No separate pyrite concretions have been formed, but within limited, lenticular bodies the pyrite has replaced the greater part of the calcite. In the least transformed parts the pyrite in the usual 
manner has been deposited in all pores and less compact parts of the shells, so that the rolled shells are speckled with small lumps and irregularly formed concretionary masses. In this way the pyrite has not only replaced the calcite but also a part of the glauconite which has impregnated the shells. The coproliths, too, are very much pyritized, whereas the coarsecrystalline calcareous cement is quite pure and free of pyrite impregnation.

Where pyritizing has been more advanced we find all the interstices between the lime particles infilled with pyrite, and the calcareous shells themselves to a great extent have been replaced by this mineral. In the border of the pyritized part of the rock we find that the shell particles are sometimes almost entirely transformed into pyrite, whereas the intermediate substance consists of quite pure calcareous cement. Thus it is evident that the pyritizing process has started in the shells and from there has grown out in the interstices between the grains. All the circumstances show that glauconitizing has preceded pyritizing, whereas cementation is the final process in the rock.

\section{The Limestone Pebbles from the Hardened Paleocene.}

Most of the pebbles in the shelly conglomerate from the various localities in Copenhagen are dark grey, more rarely lighter or yellowish limestone. In some cases the surface is very green, and then the green colour extends more or less into the pebble. Rosenkrantz (1924 p. 13) distinguishes between two types of pebbles, one of greyish-white limestone and one that is dark grey with a greenish tint and a green surface layer. Only one single specimen of the quite light type has been found, so that I have not been able to examine that type under the microscope. Of the darker limestone pebbles I have examined several sections. Rosenkrantz connects the dark grey colour with a glauconitizing process, but there are also dark grey pebbles which do not reveal the slightest degree of glauconitizing.

The grey pebbles with no glauconite coat prove to be Saltholm limestone of exactly the same type as that which forms the substratum of the Paleocene in the blocks from South Harbour Excavation I, except that the lime grains are more pyritized. As in the limestone from the South Harbour blocks there is sometimes a few, rounded glauconite grains in the rock and the calcareous cement is quite pure and clear. A few of the grey pebbles contain a small quantity of glauconite as a pigment in some of the lime grains, but otherwise conform to the type described.

The glauconitized pebbles consist of lime-sand of similar type. In these the glauconite has permeated the lime grains in the same manner as in the Paleocene rocks, and often it fills the cavities in the foraminiferal shells. Besides as pigment in the lime grains, the glauconite also occurs, however, in the form of a kind of cement or interstitial mass between the 
lime grains. This glauconite is to be found particularly in the outermost part of the pebbles, on the boundary against the surrounding rock, and it passes smoothly into the glauconite which has permeated the lime grains. Thus there is no doubt that the glauconitizing of the lime grains and of the spaces between the grains has taken place simultaneously. It is easy to distinguish between the glauconite cement and the distinct round and lobate glauconite grains which occur scattered in the rock, as the former is somewhat paler and more yellowish.

The glauconite cement envelops not only the clastic lime grains but also irregularly formed, angular, clear calcite grains which without doubt are calcareous cement (Plate 1 Fig. 5). In places the glauconite mass occurs in such a manner that the present cement consists of a mass of densely packed, clear calcite particles surrounded by a thin skin of glauconite. Having regard to all these circumstances there is no doubt that to a great extent the glauconitizing of the pebbles took place after the pebbles had hardened.

The extremely small number of limestone pebbles found in the shelly conglomerate indicates that the Danian lime-sand has only been very slightly hardened at the beginning of the Paleocene; and the fact that the Danian lime grains and derived fossils occur in such numbers in the Paleocene rocks also points in the same direction, as mentioned above. Hardened parts capable of giving rise to the formation of pebbles in the Paleocene can only have been present to a very limited extent.

\section{The Paleocene at Vodroffsvej.}

The samples from Vodroffsvej display slightly hardened greensand overlying slightly hardened Danian lime-sand.

The greater part of the lime-sand is pale yellowish grey, but the upper portion of it is darker, brownish grey. Microscopic examination reveals that the structure of the lime-sand is exactly the same in the light and in the darker parts, and the samples show with great distinctness that the dark colour is the result of a secondary percolation of pigmentary substances. These have deposited themselves in strata completely parallel with one another. RosENkRANTz erroneously assumes that the distinct boundary between the light and the dark lime-sand is the border between lime-sand and greensand, and figures this border in one of his treatises (1924, Fig. 2, page 11).

Overlying the dark lime-sand is greensand, which is immediately recognizable by its distinctly green colour. Its lower part is very much coarser than the lime-sand and contains a quantity of coarse glauconitized Danian fossils. At Vodroffsvej we thus have a shelly gravel which corre- 
sponds to the shelly conglomerate in the other localities in Copenhagen. Over the coarser layer there is normal, slightly hardened greensand.

The Danian lime-sand consists of rounded lime particles of the same appearance as those in the limestone in the boulders in the South Harbour. It also contains foraminifera, fragments of bryozoa and a few round or lobate glauconite grains. A count shows that there are equal numbers of glauconite grains in the pale and in the dark rock. The size of the sandy grains is $0.15-0.30 \mathrm{~mm}$. The rock is very porous and there is no distinct cement.

Glauconite as an impregnation of lime grains is very rare, but a few lime grains are slightly glauconitized. Pyrite is present in rather large quantities, exclusively in the form of an extremely fine pigment which is very unevenly and patchily distributed, and often coats some of the cavities or entirely infills the pores between the lime grains.

At the Mineralogical Museum there are hardened rock samples from deeper strata in the same locality. These samples, which are marked "Saltholm limestone", are of exactly the same type as the limestone from the South Harbour blocks. The grain size, as well as the character of the grains and the glauconite content, is the same in the South Harbour boulders and the Vodroffsvej hardened and unhardened lime-sand rocks.

The Paleocene shelly gravel (Plate 1Fig. 6). In all essentials the clastic components are the same as those in the other localities, but often they are considerably corroded, while at the same time new, secondary calcite has begun to deposit itself. Sometimes the shell fragments and the lime sand particles lie close together, so that no space is visible between them, and sometimes they are more separate, the rock being porous. In some places there is a fine, homogeneous matrix of brownish colour, containing extremely fine calcareous particles and presumably a quantity of argillaceous substance. All these features tend to make the microscopic picture some what confused. At times it is almost impossible to say which is lime grain and which is matrix.

The gravel particles (echinoderm and bryozoan remains, etc.) are glauconitized and pyritized in the usual manner.

A rena ce ous com pon ents. The lime grains are very impure, brownish or grey. In addition they are often glauconitized and pyritized. The diameter of the lime grains is mostly round about $0.2 \mathrm{~mm}$, and of the same size are the glauconite grains which are scattered about in the rock in larger quantities than in the underlying lime-sand. Of allochthonousclastic components, quartz is fairly common. The quartz, which occurs in the form of angular grains of a diameter of 0.1 to $0.2 \mathrm{~mm}$, is not distributed evenly, being accumulated in groups. 
Apart from glauconite in the form of grains with a sharp and distinct border there is glauconite in the matrix. This glauconite occurs in the form of green squeezed-out masses lying between the sandy components and passing into the brownish argillaceous matrix in such a manner that it is impossible to say where the glauconite ends. At some places there are large areas of these glauconitic masses which, in the form of cement, surround the clastic components (Plate 1 Fig. 6). The glauconite masses have a brownish-green colour which differs somewhat from the colour of the glauconite grains, so that one can easily distinguish the dark-green glauconite grains from the surrounding glauconitic mass. On the other hand, the pigmentary glauconite in the lime grains is indistinguishable from the surrounding glauconite. The structure of the interstitial glauconite is sometimes entirely homogeneous, consisting as it does of a fine aggregate, but there may also be an irregular banded or smeary structure, and in such cases it is made to stand out by the presence of fine grains of pyrite lying in smears arranged in the same direction as the glauconite. The smeary glauconite passes insensibly into brown smeary masses which permeate large parts of the rock as a matrix and which must be presumed to consist partly of weathered glauconite, partly, may be, of argillaceous matter.

The mode of appearance of the glauconite is of great interest of our understanding of the formation of this mineral. The similarity of colour between the cementing interstitial glauconite and the pigmentary glauconite in the lime grains, and the circumstance that the two types pass insensibly into each other, show that they are contemporaneous; this glauconite is autochthonous. On the other hand the diverging colour of the glauconite grains, their sharp delimitation against the surroundings, and the circumstance that they are sometimes inclosed in the cementing glauconite, shows that the glauconite grains are older than the pigmentary glauconite, and the agreement of the grain size with the lime grains indicates that they were sorted and transported together with the other clastic grains.

Cementing. The lime grains, all of which are of organic origin, are often surrounded by small crystals of calcite, which are arranged in such a manner that they form an optical unity with the grain in question. These calcite crystals, which are quite clear and pure, show what the process of cementation of the greensand has been: first a quantity of calcite crystals were formed on the clastic lime grains, but with further growth the true external crystal form was lost during the forming of a crystalline aggregate of clear calcite.

The greensand. The shelly gravel passes into finer greensand with a main grain size of 0.15 to $0.2 \mathrm{~mm}$. The grain size is exactly the same as in 
the Danian lime-sand, and the sandy lime components are the same. There is a difference between the lime-sand and the greensand in the glauconitizing of the lime grains, which plays no great rôle in the Cretaceous rock, whereas a large part of the grains are impregnated with glauconite in the Paleocene rock. Pyrite is present in almost equal quantities in the two rocks; but whereas in the lime-sand this mineral mostly occurs in the interstices between the grains, in the greensand it occurs both in this form and as pigment and concretions in the lime grains. There is also a great difference in the quantity of glauconite grains. A count made on the slides shows that the greensand contains seven to eight times as many glauconite grains as the lime-sand. The number of quartz grains is also greatest in the greensand. The matrix between the sand grains in the greensand, as in the shelly gravel, consists of a brownish, calcareous and argillaceous matter, which sometimes passes into brownish and greenish glauconitic smeary masses. An incipient cementation like that described in the shelly gravel is also visible in the greensand.

\section{The Paleocene at Vestre Gasværk.}

In the spring of 1930 a fresh excavation was made of JoHnstrup's 1868 locality for the purpose of finding out the stratigraphical position of the series and of collecting fossils from it. This excavation, which was taken down through the Paleocene into the Saltholm limestone, was described by Rosenkrantz (1930). In 1931 Johnstrup's 1874 locality, which lies 200 metres more to the northeast, was excavated. The latter excavation comprised only the upper strata of the series, but for the most part layers that had been eroded by the ice in the 1930 locality. By means of the petrographical analyses parallelization is possible between the layers in the two excavations.

Taking them on the whole, there seems to be an insensible transition between the various rocks, so that it is difficult to indicate exact boundaries for the different rock types.

Over the Saltholm limestone lies about $0.4 \mathrm{~m}$ of hard greensand limestone, which is the hardened lower part of the greensand deposits. Over this lies about $3 \mathrm{~m}$ of slightly hardened greensand, which upwards insensibly passes into more fine grained and more and more clayey deposits, ending with blackish-grey marl. The Paleocene deposits are covered by moraine. The thickness of the series is about $6.6 \mathrm{~m}$.

The two excavations gave the following results (the figures represent the depth of the strata in metres below mean water level): 
Vestre Gasværk Excavation 1930.

6.0- 6.2 Dark-grey sandy marl, impregnated with moraine.

6.2- 6.6 Dark grey, clayey, fine greensand, irregularly stratified.

6.6- 6.8 Greenish-grey, fine greensand.

6.8- 7.1 Greenish-grey, coarser greensand with phosphorite nodules.

7.1- 7.5 Greensand with ophiomorphs.

7.5- 8.3 Greensand.

8.3- 8.4 Shelly gravel of Danian fossils.

8.4- 9.8 Greensand.

9.8-10.2 Hard greensand limestone.

10.2- Saltholm limestone.
Vestre Gasværk Excavation 1931.

5.6-6.0 Black-grey marl.

6.0-8.2 Dark-grey sandy marl, comprising irregularly alternating more sandy and more clayey areas; uppermost with a number of hard lumps, partly pebbles.

8.2-8.6 Irregularly stratified rock like the above, but more sandy, more deserving the name of clayey fine greensand.

8.6-8.8 Greenish-grey, fine greensand.

8.8-9.1 Greenish-grey, coarser greensand with phosphorite nodules.

\section{The Greensand Limestone.}

The greensand limestone has been examined under the microscope in a thin section. In all essentials it is the same as the greensand limestone from the South Harbour and the other localities. Arranged in irregular layers there are brownish smears and areas of glauconitic interstitial masses as in the greensand at Vodroffsvej. It is clear that the cementation has taken place subsequent to the formation of the glauconite, for the glauconite masses never contain clear calcite, only clastic lime grains. On the other hand it is often seen that newly-formed crystals of calcite from the lime grains extend into the glauconitic interstitial mass, and it is thus assumable that the glauconite has been soft and yielding at the time when the rock was cemented.

\section{The Unconsolidated Samples.}

Of the loose samples 17 have been selected and subjected to a mechanical analysis. Thereafter an accurate mineralogical analysis was made of No. 1, 5, 10, 11, V and VI. The samples examined are: 


\begin{tabular}{|c|c|c|c|c|}
\hline \multirow{12}{*}{\multicolumn{2}{|c|}{ Excavation 1930.}} & Sample No. & Depth & Rock \\
\hline & & 11 & $6.2-6.3$ & Clayey fine greensand. \\
\hline & & 10 & $6.6-6.8$ & Fine greensand. \\
\hline & & 9 & $7.0-7.1$ & Greensand. \\
\hline & & 8 & $7.4-7.7$ & ,, \\
\hline & & 7 & $7.8-7.9$ & ,, \\
\hline & & 6 & $8.2-8.3$ & , \\
\hline & & 5 & $8.3-8.4$ & Gravel of Danian fossils. \\
\hline & & 4 & $8.5-8.6$ & Greensand. \\
\hline & & 3 & $8.9-9.0$ & , \\
\hline & & 2 & $9.3-9.4$ & , \\
\hline & & 1 & 9.8 & , \\
\hline \multirow[t]{6}{*}{ Excavation } & 1931. & VI & $5.6-5.8$ & Black-grey marl. \\
\hline & & $\mathrm{V}$ & $6.5-6.8$ & Dark-grey sandy marl. \\
\hline & & IV & $7.6-7.8$ &, \\
\hline & & III & $8.0-8.2$ & , \\
\hline & & II & $8.6-8.8$ & Fine greensand. \\
\hline & & I & $9.0-9.1$ & Greensand. \\
\hline
\end{tabular}

The lowest part of the unconsolidated series (Samples 1-9 and I) consists of a greenish-grey, fine-grained sandy rock which, owing to its clay content and an incipient cementation is so compact and coherent that it may perhaps be described as an incoherent sandstone. Some of the lowest samples contain a quantity of rolled, glauconitized Danian fossils (Fig. 5) which lie scattered in the rock, but often with a tendency towards a stratified arrangement, whereby the rock consists of alternating thin layers with and without gravel components. Also one or two small pebbles of slightly hardened Danian lime-sand have been found. A pronouncedly gravelly layer, quite uncemented, was found in the 1930 Excavation at a depth of $8.3-8.4 \mathrm{~m}$. As a rule, no special structural features are to be seen in the rock apart from a bedding, observable from the fact that there are darker clayey surfaces at a distance of 10 to $20 \mathrm{~cm}$ from one another. In the greensand there are also ophiomorphs with their surfaces coated with clay, so that they stand out distinctly in the samples. They are especially frequent at depths round about 7.1-7.5 $\mathrm{m}$ in the 1930 Excavation. They consist of unbranched, mostly straight tubes with a breadth of about $8 \mathrm{~mm}$. In most cases the ophiomorphs lie on the bedding planes, and then the cross-section of the tubes becomes oval; more rarely they lie more or less at an angle to the stratification and are circular in crosssection. Presumably the tubes are to be regarded as worm trails, as they are all unbranched and of about the same diameter. The Danian limesand deposits at Copenhagen also contain ophiomorphs of the same type as those of the Paleocene.

At a depth of about $6.8-7.1 \mathrm{~m}$ in the 1930 Excavation, and about $8.8-9.1 \mathrm{~m}$ in the 1931 Excavation, the greensand contained a quantity of irregular phosphorite nodules of a size usually between 10 and $40 \mathrm{~mm}$. 
The upper part of the greensand becomes somewhat finer grained, and there appear more and more clayey surfaces and a few layers, millimetres thick, of more argillaceous character. This takes the rock over into fine clayey greensand, which forms the transitional rock from the underlying coarser greensand deposits to the overlying marl deposits. The transition seems to be quite gradual and, gradually as the quantity of clayey portions gains the upper hand, the rock assumes the character of a sandy marl. Like the fine, clayey greensand, this has a very irregular stratification,

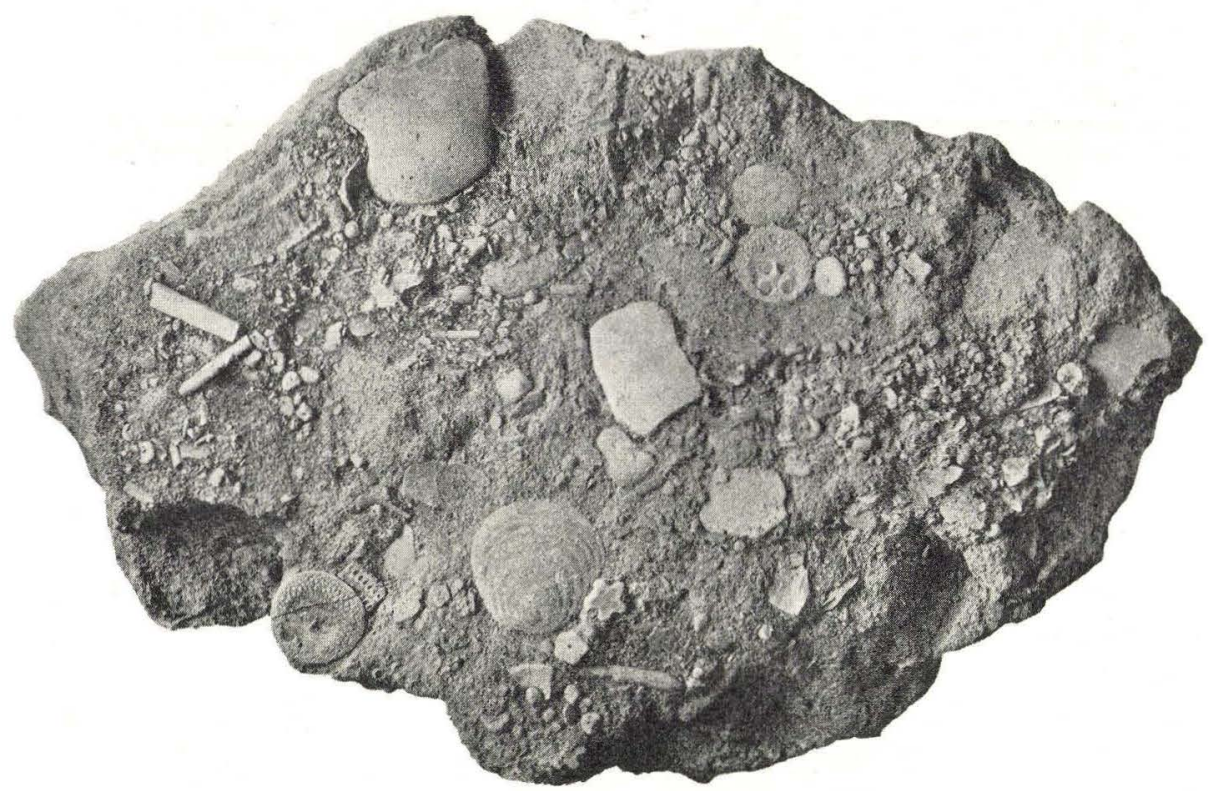

Fig. 5. Surface of greensand, with derived fossils. Vestre Gasværk 1930. - 9.8 m. (Nat size).

there being a constant alternation between more sandy and more clayey lenticular areas passing gradually into one another; however, there are also more sharply delimited, rounded, isodiametrical, sandy areas interspersed in the rock, and these make the rock resemble a conglomerate (Fig. 6). Whilst it is impossible to determine whether the lower parts of the marl series is actually a conglomerate or merely of a conglomeratic structure, it is beyond question that the upper part of the marl series really has been developed as an intraformational conglomerate, for here the marl contains harder lumps, which cannot be concretions; the stratification in these pebbles is not parallel with the stratification in the marl (Fig. 7). Petrographically the hard portions are not very different from the marl, though as a rule they are more sandy and more or less silicified. Usually the lumps are sub-rounded and vary much in size, though in most cases the diameter lies round about $30 \mathrm{~mm}$. It is to be assumed that on the sea-floor at the time there has been an initial silicification of a 


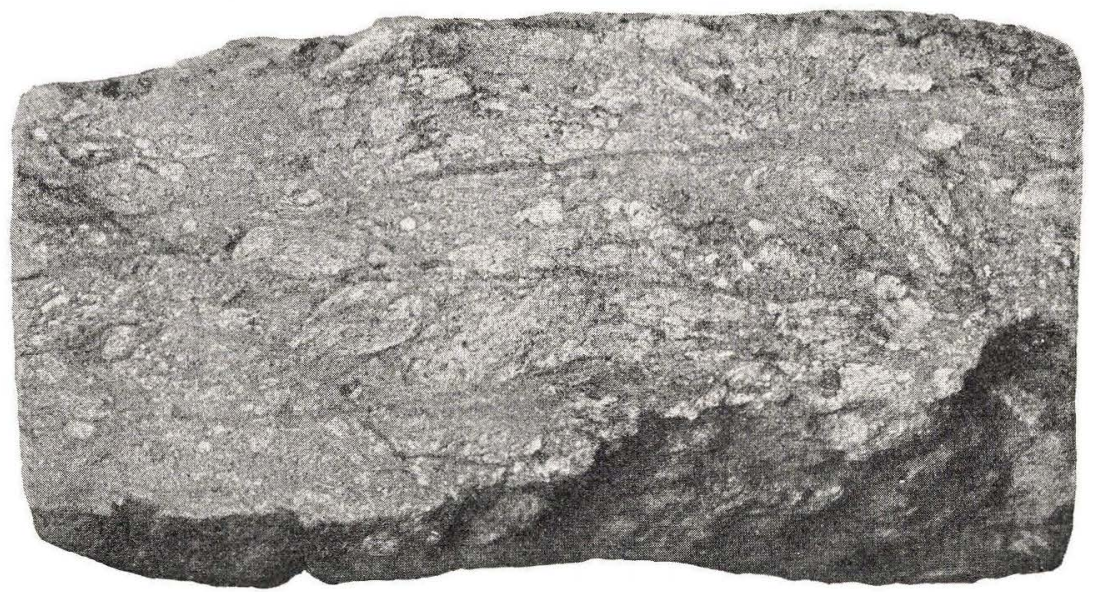

Fig. 6. Clayey fine greensand, with irregular stratification. Vestre Gasværk 1930. -6.2 to $-6.3 \mathrm{~m}$. (Nat. size).

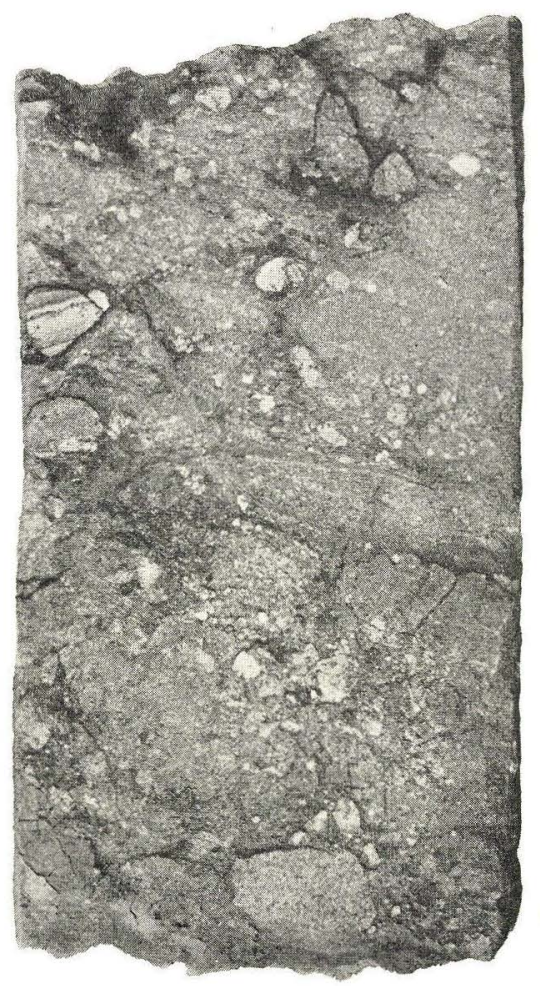

Fig. 7. Sandy marl; intraformational conglomerate. Vestre Gasværk 1931. -6.2 to -6.5 . (Nat. size). 
layer that has been slightly more sandy than usual, and the slightly silicified parts in the form of rock fragments have been broken up and interbedded in the marl. - It is possible that there is a similiar slightly coarser and silicified rock in the form of a continuous layer over the marl in Kongedybet (see page 55).

\section{Mechanical Analyses.}

The results of the mechanical analyses are given in Table 1 and 2 , the section drawings (Fig. 8 and 9) and the distribution pyramids (Fig. 10).

The mechanical analyses show that the greensand consists of fine sand, though in it there is a layer of gravel, i. e. Sample 5. The fine sand has almost the same composition throughout. The mud content lies mostly between 15 and 30 per cent. The main grain size is the fraction $0.1-$ $0.2 \mathrm{~mm}$.

The fine greensand (Samples 10 and II) and the clayey fine greensand (Sample 11), which as already stated form the transition from greensand to marl, are also shown by the mechanical analyses to be

Table 1.

Mechanical Analyses, Vestre Gasværk.

\begin{tabular}{|c|c|c|c|c|c|c|c|c|c|c|}
\hline \multirow[b]{2}{*}{$\begin{array}{c}\text { Sample } \\
\text { No. }\end{array}$} & \multicolumn{10}{|c|}{ Diameter in $\mathrm{mm}$} \\
\hline & 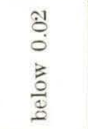 & $\begin{array}{l}8 \\
0 \\
0 \\
01 \\
0 \\
0\end{array}$ & 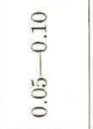 & $\begin{array}{l}\stackrel{0}{0} \\
\stackrel{-1}{0} \\
\stackrel{0}{0}\end{array}$ & $\underset{0}{10}$ & $\begin{array}{l}\stackrel{0}{-1} \\
\stackrel{1}{\circ} \\
\stackrel{0}{0}\end{array}$ & $\stackrel{9}{-1}$ & $\prod_{01}^{10}$ & $\stackrel{0}{1}$ & $\begin{array}{l}\text { a } \\
\stackrel{0}{0}\end{array}$ \\
\hline 1 & 16.22 & 6.13 & 18.89 & 41.46 & 3.45 & 6.03 & 5.99 & 1.62 & 0.21 & - \\
\hline 2 & 19.13 & 6.50 & 19.70 & 42.72 & 2.86 & 4.25 & 3.39 & 1.45 & 一 & - \\
\hline 3 & 13.17 & 5.43 & 14.42 & 57.37 & 8.84 & 0.49 & 0.20 & 0.08 & - & 一 \\
\hline 4 & 17.96 & 4.95 & 12.62 & 53.93 & 8.80 & 1.28 & 0.35 & 0.11 & - & - \\
\hline 5 & 3.46 & 2.87 & 10.05 & 24.02 & 6.55 & 12.73 & 13.12 & 20.06 & 6.97 & 0.17 \\
\hline 6 & 22.37 & 8.56 & 25.80 & 40.79 & 1.43 & 0.46 & 0.25 & 0.34 & & \\
\hline 7 & 20.53 & 8.45 & 25.61 & 43.18 & 1.88 & 0.26 & 0.09 & - & - & - \\
\hline 8 & 16.58 & 8.33 & 25.59 & 45.78 & 3.12 & 0.44 & 0.16 & - & 一 & - \\
\hline 9 & 17.80 & 7.28 & 20.16 & 43.56 & 8.64 & 1.76 & 0.60 & 0.20 & - & - \\
\hline 10 & 26.94 & 9.25 & 28.80 & 28.88 & 4.26 & 1.19 & 0.40 & 0.28 & - & - \\
\hline 11 & 54.13 & 12.99 & 26.43 & 6.10 & 0.15 & 0.09 & 0.09 & 0.02 & - & - \\
\hline I & 20.82 & 7.05 & 28.22 & 37.20 & 5.27 & 1.09 & 0.35 & - & - & - \\
\hline II & 29.30 & 9.50 & 36.00 & 21.54 & 2.80 & 0.62 & 0.20 & 0.04 & - & - \\
\hline III & 63.99 & 12.58 & 21.20 & 2.06 & 0.10 & 0.07 & - & - & - & - \\
\hline IV & 61.80 & 15.30 & 21.19 & 1.58 & 0.08 & 0.05 & - & - & 一 & - \\
\hline V & 66.12 & 13.52 & 16.33 & 3.55 & 0.21 & 0.10 & 0.17 & - & - & - \\
\hline VI & 67.65 & 22.31 & 8.87 & 0.88 & 0.17 & 0.07 & 0.05 & - & 一 & - \\
\hline
\end{tabular}


transitional rocks, as the diameter for the maximum grain size is slightly less than in the greensand, and the mud content increases upwards.

The sandy marl (Samples III-V) contains 60-70 per cent. mud, and the sandy components are almost all between 0.02 and $0.1 \mathrm{~mm}$, the maximum lying in the fraction $0.05-0.1 \mathrm{~mm}$.

The uppermost marl sample from the 1931 Excavation (Sample VI) has a sand content similar to the others, but in this case the highest sand percentage lies in the finest fraction, $0.02-0.05 \mathrm{~mm}$.

The distribution pyramids of the greensand display certain extremely characteristic features. They reveal a pronounced maximum, much the higher percentage of grains falling within two classes, viz. in the interval ${ }^{1 / 16} \leftarrow^{-1 / 4} \mathrm{~mm}$. In samples containing any noteworthy quantity of coarse particles the latter form a separate maximum, so that the curve becomes double-crested. This secondary maximum lies in the classes $1 / 2-2 \mathrm{~mm}$, i. e. the distance between the two maxima is $3-4$ classes, or the diameter of the gravel grains is 8 to 16 times that of the sand grains.

The pyramid for the gravel (Sample 5) also has a double-crested curve, and the maximum representing the fine particles lies in the same two

Table 2.

Mechanical Analyses recalculated to UDden's Scale, Vestre Gasværk.

\begin{tabular}{|c|c|c|c|c|c|c|c|c|c|c|c|}
\hline \multirow[b]{2}{*}{$\begin{array}{c}\text { Sample } \\
\text { No. }\end{array}$} & \multicolumn{11}{|c|}{ Diameter in $\mathrm{mm}$} \\
\hline & $\stackrel{\infty}{0}$ & $\prod_{\infty}$ & $\mathfrak{i}^{1}$ & $T_{1}$ & $\stackrel{N}{i}$ & $\underset{\vec{\rightarrow}}{\overrightarrow{+}}$ & $\stackrel{+}{+}$ & $\underset{-\infty}{\stackrel{\infty}{7}}$ & $\stackrel{\substack{0 \\
-}}{\stackrel{5}{-}}$ & $\underset{\stackrel{0}{\circ}}{\overrightarrow{0}}$ & $\begin{array}{l}\overrightarrow{0} \\
\frac{5}{0}\end{array}$ \\
\hline 1 & - & - & 2 & 6 & 6 & 2 & 25 & 33 & 8 & 3 & 15 \\
\hline 2 & - & - & 2 & 3 & 4 & 2 & 20 & 40 & 7 & 4 & 18 \\
\hline 3 & 一 & - & - & 一 & 1 & 3 & 44 & 31 & 5 & 3 & 13 \\
\hline 4 & - & - & - & 一 & 2 & 3 & 44 & 26 & 5 & 3 & 17 \\
\hline 5 & 2 & 10 & 15 & 13 & 13 & 4 & 19 & 16 & 4 & 1 & 3 \\
\hline 6 & - & - & - & 一 & 1 & 1 & 23 & 40 & 10 & 3 & 22 \\
\hline 7 & - & - & - & 一 & - & 1 & 22 & 44 & 10 & 3 & 20 \\
\hline 8 & - & - & 一 & - & - & 2 & 26 & 42 & 10 & 4 & 16 \\
\hline 9 & & 一 & - & 1 & 2 & 3 & 34 & 32 & 7 & 4 & 17 \\
\hline 10 & - & - & $\longrightarrow$ & 1 & 1 & 1 & 20 & 35 & 12 & 4 & 26 \\
\hline 11 & - & - & - & - & - & - & 3 & 20 & 19 & 5 & 53 \\
\hline I & - & - & - & - & 1 & 2 & 27 & 36 & 11 & 3 & 20 \\
\hline II & - & 一 & - & - & 1 & 1 & 12 & 38 & 17 & 3 & 28 \\
\hline III & & & - & & & - & 1 & 15 & 16 & 5 & 63 \\
\hline IV & - & 一 & - & - & - & - & 1 & 13 & 19 & 7 & 60 \\
\hline $\mathrm{V}$ & & - & & & - & & 2 & 12 & 15 & 7 & 64 \\
\hline VI & - & - & - & - & - & - & 1 & 5 & 15 & 17 & 62 \\
\hline
\end{tabular}


classes as the maximum of the other samples. The greater part of the coarse particles lie in the classes $1 / 2-8 \mathrm{~mm}$ and their average diameter is thus about 16 times that of the fine sand.

The mechanical composition of the samples that have double-crested curves necessitates further discussion. As stated, the maximum of the fine

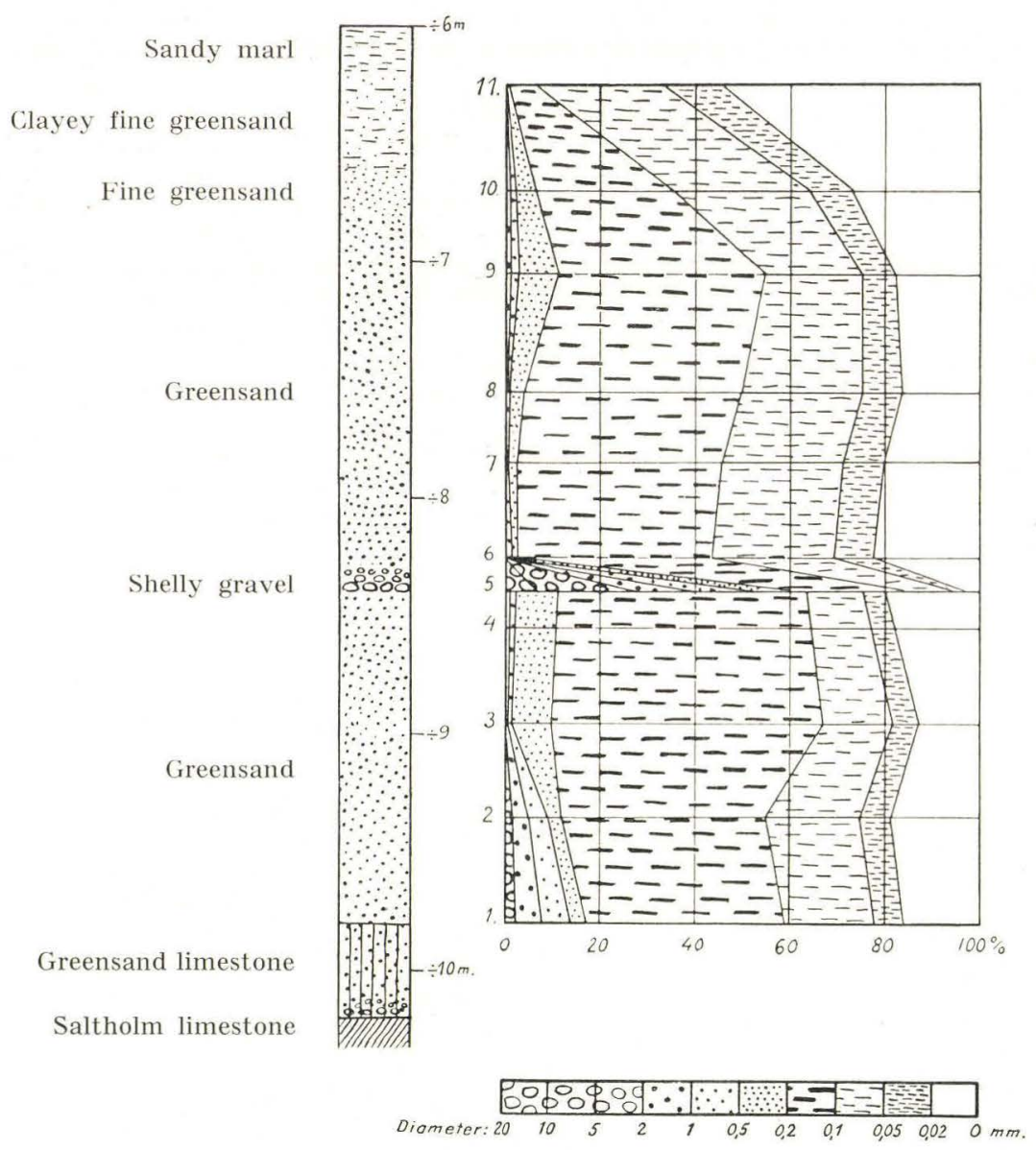

Fig. 8. Mechanical composition of the rocks in the section at Vestre Gasværk, Excavation 1930.

components lies in the same interval as far as both the single and the double-crested curves are concerned. This shows that the sorting forces during the deposition of the gravel have not been different in intensity from those which caused the sorting and deposition of the other parts of the series. Accordingly, the accumulation of gravel particles must be the result of other conditions, and the assumption nearest to hand is that it was due to fresh supplies of material to the sedimentation area. UDDEx, who has examined the laws 
of sorting and the mechanical composition of clastic sediments, has formulated the following law on "the secondary maximum": When a transporting medium is supplied with sufficiently heterogeneous material, it will tend to carry and to deposit two certain sizes of grain: those which the stream can momentarily lift and those it can roll. For water deposits the coarse particles will have a diameter of about 16 times that

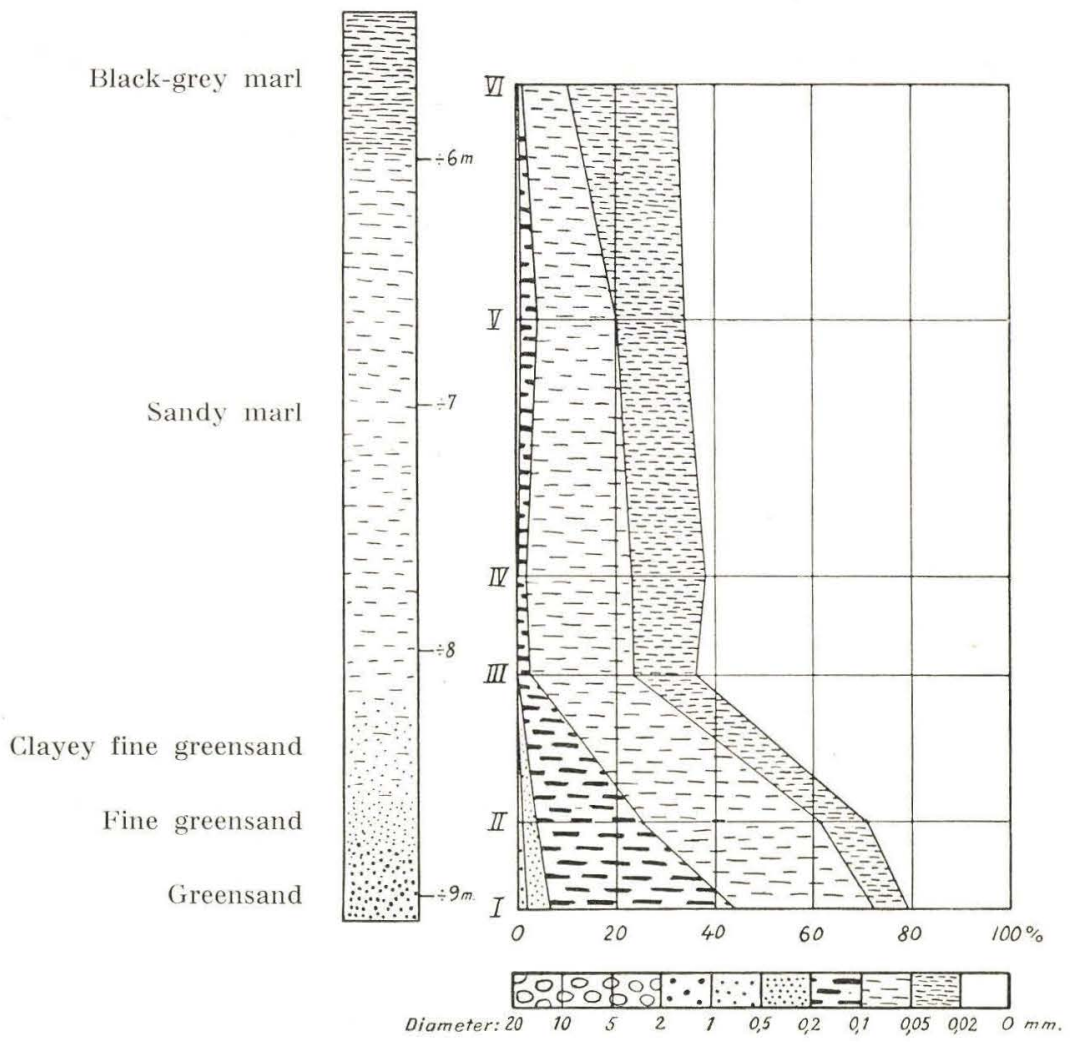

Fig. 9. Mechanical composition of the rocks in the section at Vestre Gasværk, Excavation 1931.

of the fine particles. (J. A. UdDen 1914, page 737). The agreement between this law and the mechanical composition of Samples 1,2 and 5 is evident.

The very large quantity of gravel and coarse sand in the gravel stratum would seem to indicate that a quantity of fine material has been removed. Once the deposit of gravel and fine sand has been formed, very small differences in the movement of the water will be sufficient to wash out the fine particles. The gravel, Sample 5, in its mechanical composition mostly resembles certain gravel deposits mentioned by LUGN under the name of "lag concentrates" (A. L. LUGN 1927). His investigations com- 

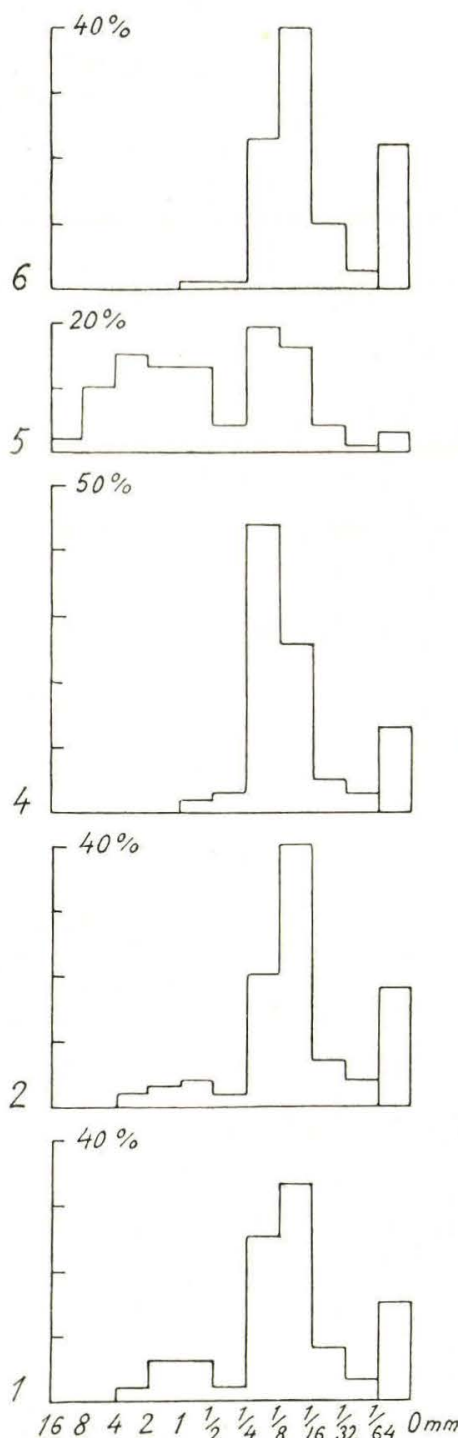
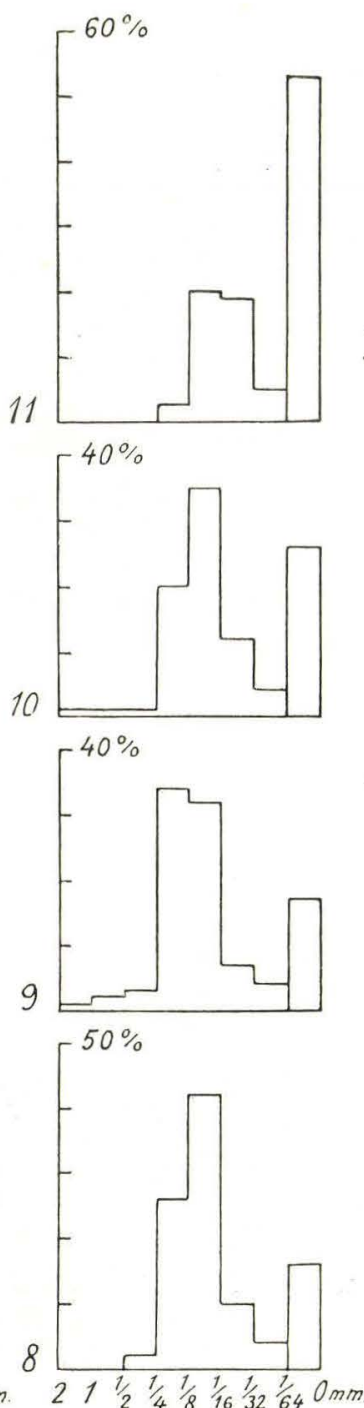
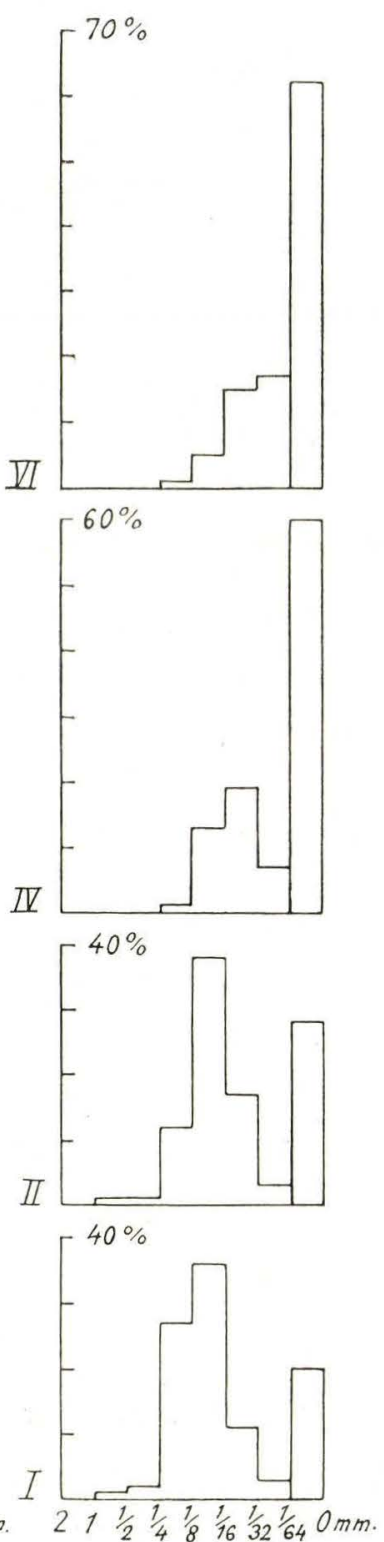

Fig. 10. Distribution pyramids, Vestre Gasværk.

prise fluvial sediments from the Mississippi, and among them the said type of gravel has actually been formed by the removal of finer components, leaving the coarser ones behind. The formation of "lag concentrates" proceeds especially where the stream cuts into earlier deposits, i. e. where there is an ample supply of fresh, heterogeneous material.

The analyses of the sandy marl (Samples III-V) show that the sandy components make up a separate maximum with a grain size of 
about ${ }^{1 / 16} \mathrm{~mm}$, so that the greater part of the fine sand and silt lies within the interval $1 / 32^{-1 / 8} \mathrm{~mm}$. The large proportion of mud (about 65 per cent.) as well as the small number of grains in the interval $1 /{ }_{64}-1 / 32$ $\mathrm{mm}$, show that the sand and the mud may be regarded as two separate components in the sediment, which as a matter of fact appeared from the rock structure with the alternating strata of sandy and clayey portions. Accordingly, the analysis results may be explained by assuming that the intensity of the movements of the water has decreased somewhat, whereby the size of the sand grains has become slightly smaller, and the deposition of allochthonous mud has been made possible to a greater extent than before.

Presumably the uppermost marl sample (VI) was built up analogously with the others; but it cannot be decided from the distribution pyramid if the silt particles form a separate maximum.

In brief outlines the mechanical analyses show the following:

The analyses of the greensand reveal a very thorough sorting and the size of the coarser particles corresponds to the intensity of the active forces, if we assume that they were rolled and the fine grains suspended. The gravel deposit marks no new physical conditions, but merely a supply of fresh material to the sedimentation area. In the upper parts of the series a decrease of the intensity of the water movement is perceptible: the rock becomes clay with finer sand, deposited under less agitated conditions.

\section{Mineral Content.}

The gravel components are exclusively rolled Danian fossils, glauconitized in the same manner as in the hardened rocks in Copenhagen. The coarsest fractions consist mostly of fragments of Terebratula and Crania shells and echinoderms; in the finer fractions crinoid stem ossicles and Ditrupa shells are most frequent. The fossils agree with those found in the lime-sand under the Paleocene.

Arenaceous components. The sand grains vary a great deal as to origin. Most of them are calcareous, and subordinately there are allochthonous-clastic grains, glauconite and pyrite concretions.

The calcareous grains. All the lime grains that can be identified prove to be parts of organisms, but the greater part occurs as a clastic component in the sediment. In the coarsest fractions, which contain many fragmentary bryozoa and foraminifera, the grains are often more or less glauconitized by pigmentary glauconite, slightly pyritized. The finest lime grains are usually purer. Not uncommonly we find a coating of secondary calcite on the individual lime grains, a coating which, as in the rock at Vodroffsvej, is observable in 
the fact that the lime grains are surrounded by small clear crystals forming an optical unit with the calcite of the grain. - The smaller lime grains, up to $0.5 \mathrm{~mm}$, are angular or slightly rounded. The larger grains in the lower samples consist mostly of extremely well-rounded Danian fossils, but in the upper samples mostly of fresh Paleocene foraminifera as well as fresh shell fragments of Paleocene gasteropods, etc.

Allochthonous-clastic grains. Quartz and felspar (mostly orthoclase and microcline, very subordinately plagioclase) occur in most fractions, white mica mostly in the finest fractions. The quartz and felspar are to be found as angular grains in the finest fractions, as subrounded grains in the fraction $0.1-0.2 \mathrm{~mm}$ and as well-rounded grains in the larger fractions. Sometimes the grains are more or less coated with glauconite, or glauconite has made its way into fissures in the grains. Pyrite also occurs in the same manner, both pigmentary and on the surface. Of more rare allochthonous-clastic minerals there are hornblende and tourmaline especially, whilst only a very few grains of garnet and zircon have been found.

Glauconite is found partly in the form of grains with an even, smooth surface, partly as pigment in lime grains or as infilling of fissures and cavities in them.

Glauconitizing of the lime grains has been referred to in the foregoing (page 27). Treating the various fractions with dilute hydrochloric acid gives a good impression of the occurrence of the glauconite (Plate 2, Fig. 1). The pigmentary glauconite forms remarkable reticulations, distorted, ramified masses and rod-like and wormy bodies. RøRDAM saw this in the greensand limestone from Larsens Plads; he assumed that these glauconite masses are spicules and therefore calls the rock spongia limestone. However, that these branchy and distorted glauconite masses are pigmentary glauconite is clear from a comparison with the observations of the thin sections from greensand limestone samples, which do not contain spicules in the matrix as RøRDAM supposed; it is also clear from the circumstance that glauconite of these forms does not occur in the original fractions, but appears on treating the fractions with acid. Furthermore, I have revealed corresponding forms by acid-treating certain glauconitized fossils whose surface had been carefully cleaned. Glauconite masses which greatly resemble spicules can be had from Crania and Terebratula, where the glauconite has infilled the pores of the shells (Plate 1, Fig. 1, at the top to the left).

In the finest fractions pyrite occurs mainly as small concretions, either of irregular shape or small, round, botryoidal concretions. These concretions are sometimes built up of very small balls of pyrite, mostly in the upper samples. The pyrite from the coarser fractions often is 
shaped like short straight tubes which are hollow, smooth inside but rough with small crystals on the outside. There can hardly be any doubt that these small tubes are pyritized sponge spicules. In the marl series there is a small quantity of pyrite concretions, the triangular shape of which shows that they must have been formed in diatoms. On the whole the marl series contains much more pyrite than the greensand, and the spherical structure of the pyrite as well as the occurrence of pyritised diatoms are features which prove that the marl is more closely associated with the Kerteminde marl than the greensand is. (See page 73$)$.

Of other components of sand size there are chalcedony and opal. The former is mostly found in the form of sponge spicules, and sometimes as accidentally formed, sharp-edged grains which presumably are, partly, fragments of spicules and, partly, fragments of silicified rock. The opal also occurs as spicules, in which case it usually has a dark brownish colour. In the acid-treated fractions one also finds a perfectly clear mineral, single-refracting with very low refractive index. In the coarser fractions it occurs mostly as infilling of foraminifera, in the finer ones as fragments with straight edges. It can scarcely be other than opal, secondarily formed on the spot. On being magnified to a high power it can be seen that the mineral is always built up of the straight-edged particles that are found in the finer fractions. The immediate impression given is that this structure is the result of fractures on account of internal tension in the mineral.

There is phosphorite in the rock in the form of coproliths; gypsum occurs in very small quantities in some of the uppermost rock samples, which are slightly weathered, and it undoubtedly was formed by the weathering of pyrite. Some of the glauconite grains in these samples are more brownish in colour than usual end partly weathered, forming opal of the type described, and limonite. (See p. 101).

The mud. To a great extent this consists of calcite, mostly in the form of small, clear, isodiametric, angular grains. In the entire series, right from its lowest to its uppermost part, there are also coccoliths, but in rather small numbers. Among the larger grains of the mud there are otherwise allochthonous-clastic components as well as glauconite and pyrite. As will be shown later (page 49), it must be assumed that in the lower part of the series, the mud mainly consists of calcite and glauconite, whereas in the upper part of the series the principal constituent of the mud is terrigenous clay.

The organisms. The Copenhagen rocks being mainly fragmental deposits, organisms play no great part in them. It is a different matter that almost all the lime grains are of organic origin, but in the Paleocene rocks they occur as a clastic component. Only those organisms 
will be summarised here which have lived at the time of the deposition of the rock and later have formed a part of it.

Coccoliths occur in rather small quantities, even in the lowest and most sandy rocks, but probably they are of rather greater frequence in the marl deposits.

Foraminifera are frequent in all the rock samples. It is difficult to decide how great a portion of the foraminifera in the finer fractions are Paleocene; but, as many of the small foraminifera are quite pure, some of them undoubtedly are Paleocene. In the coarser fractions of the marl series the lime grains to a very great extent consist of fresh Paleocene foraminifera. Silicified foraminifera are sometimes found in the acid-treated material, but, if anything, these are probably Danian.

Diatoms are present in the marl in small quantities, but not in the greensand. In all cases they have been transformed into pyrite.

Sponges are present in the greensand as a rather subordinate component, but more frequently in the marl. Their spicules occur but rarely untransformed as opal of a brownish-grey colour. Often they have been transformed into chalcedony and not infrequently into pyrite. Spicules consisting of opal or chalcedony often contain glauconite in the inner cavity. Irregular forms of spicules are fairly rare and the greater number of them are straight, or more rarely regularly rayed needles. In the slightly harder, partly silicified pebbles in the upper part of the marl there are numerous spicules preserved as opal, both irregular and needle-shaped.

Coproliths of the type described under the hardened rocks occur only in the lower parts of the greensand.

Fragments of shells of Paleocene gasteropods and lamellibranchs occur subordinately in the analysed samples.

It is evident from the description of the Paleocene greensand deposits compared with the underlying calcareous rocks that the lime grains must be regarded as a clastic component originating from the disintegrated Danian rocks; as has been stated, Rosenkrantz has already drawn attention to this. Contrasting with the lime sand components are the allochthonous-clastic components, quartz, felspar, etc., which have come from more distant regions.

Thus in the Paleocene rocks it is easy to distinguish between the autochthonous and the allochthonous clastic minerals, the lime sand belonging to the first group, whereas quartz, felspar, mica, etc. belong to the second. It must be pointed out, however, that the lime sand components are not strictly autochthonous, but are more or less sorted and have been transported a shorter distance than the allochthonousclastic minerals. The literature contains no term for such components, transported but originating from more adjacent areas. I propose the 
word anchi-autochthonous, as designating approximate but not absolute autochthony. In the sense of "almost, not quite", the prefix "anchi" has been used by VoGT in a work on "anchi-eutectic" and "anchi-monomineral" rocks. (VoGT 1905).

\section{Quantitative Proportions (Table 3).}

The counts. The proportional values of the principal components in the various fractions, viz. calcium carbonate, the allochthonous-clastic minerals, glauconite and pyrite, are given in the first column of the table.

The variation of the calcium carbonate content in the various grain sizes seems to be very irregular, which is simply due to a higher or lower content of other components. The calcium carbonate content of the mud is of particular interest to our understanding of the series, and therefore it is calculated on the basis of the calcium carbonate content of the various fractions and the mechanical analyses. The calcium carbonate content of the mud $(\%)$ appears from the following table, which also shows the calcium carbonate content of the raw samples (for rock from which grains of over $2 \mathrm{~mm}$ have been removed):

\begin{tabular}{l||c|c|c|c|c|c|c|c|c|c|c}
\hline \multicolumn{1}{c|}{ Sample No. } & 1 & 5 & 8 & 10 & 11 & I & II & III & IV & V & VI \\
\hline \hline Raw sample & 85.9 & 80.8 & 80.5 & 68.0 & 58.0 & 74.2 & 68.7 & 46.3 & 48.5 & 48.1 & 46.0 \\
Mud & 80.7 & - & 66.4 & 38.0 & 37.1 & - & - & - & - & 37.0 & 37.9 \\
\hline
\end{tabular}

It is clearly seen that both the raw samples and the mud become less and less calcareous the higher up the section they come from.

The allochthonous-clastic components have a most remarkable distribution. In all the lower samples we find that they are grouped about a maximum lying in the fraction $0.2-0.5 \mathrm{~mm}$. This maximum occurs again right up through the upper samples, but it is evident that the quantity of this sand decreases upwards in the section. In the uppermost samples, however, we find that most of the allochthonousclastic components occur in the finest fractions, whereas there are fewer and fewer in the coarser fractions.

It is probable that the varying calcium carbonate content of the mud is connected with the variation in the content of allochthonous material. In the lower samples, which for the most part contain only an intermixture of coarse allochthonous-clastic grains, the calcium carbonate content of the mud is high, and that part of the mud which is not calcium carbonate is undoubtedly glauconite to a great extent. (This in fact appears from the examination of corresponding deposits 
from Vodroffsvej). In the upper samples, which contain greater quantities of allochthonous-clastic grains in the finest fractions, the calcium carbonate content of the mud is small; here the main part of the mud is presumably terrigenous clay.

The analyses thus show that the allochthonous-clastic material must be divided into two independently occurring groups, viz. 1) large sand grains, found especially in the lower samples, and 2) clay and fine sand which increase in quantity upwards in the section. It is possible that the coarse sand should be regarded as an anchiautochthonous component, for in the Upper Danian deposits in certain areas there are rather large quantities of quartz sand. The arguments in favour of this view are, firstly, the distinct decrease in quantity upwards in the section, and secondly, the pronounced roundness of the grains. The other allochthonous intermixture, clay and fine sand, is scarcely noticeable in the lower deposits, where the rock is preponderantly formed of anchi-autochthonous components, especially lime sand; in the marl series, however, the intermixture becomes much more marked.

The glauconite in every sample is distinctly distributed round about a maximum which, in the lower samples, lies in the fraction $0.2-0.5$, in the upper samples $0.1-0.2 \mathrm{~mm}$. In the lower samples we also find an increasing quantity of glauconite in the finest fractions, a circumstance which confirms the view that the mud in the lower samples is rich in glauconite.

The pyrite is irregularly distributed in the various samples, which certainly is connected with the fact that, unlike the other components, it has not been transported and sorted, but has been formed chemically in the sea-water and on the sea floor. As it is often formed in shell cavities or at the expense of organisms, its grain size naturally depends upon the size of these organisms and not upon the grain size of the sediment in which the pyrite is formed.

The grains counted under "other constituents" are mainly opal or chalcedony, mostly sponge spicules, more rarely accidentally-formed fragments of silicified foraminifera. Undisintegrated, silicified rock and indeterminable components are subordinate.

The quantitative proportions of the allochthonous-clastic minerals (the second column of Table 3) are fairly uniform in the different parts of the series. Whereas there is only slight variation from sample to sample, there is a distinct change from fraction to fraction. Thus it is evident that the mica content is highest in the finest fraction, lower in the next finest and very low, or nil, in the coarser fractions. There are greater variations in the felspar content, but apparently with a tendency in the same direction as the mica. It is a fact that the coarsest fractions contain quartz almost exclusively. 
Table 3.

Quantitative Analyses, Vestre Gasværk.

\begin{tabular}{|c|c|c|c|c|c|c|c|c|c|c|c|c|c|c|c|c|c|}
\hline \multirow[b]{2}{*}{ 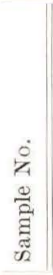 } & \multirow[b]{2}{*}{$\begin{array}{l}\text { Fraction } \\
\text { (diameter } \\
\text { in } \mathrm{mm} \text { ) }\end{array}$} & \multicolumn{5}{|c|}{$\begin{array}{l}1 . \\
\text { Counts of the Composition } \\
\text { of the Fractions }\end{array}$} & \multicolumn{4}{|c|}{$\begin{array}{l}2 . \\
\text { Allochthonous- } \\
\text { Clastic Minerals }\end{array}$} & \multicolumn{2}{|c|}{\begin{tabular}{|c|}
3. \\
Glauconite- \\
Pyrite Ratio
\end{tabular}} & \multicolumn{5}{|c|}{$\begin{array}{c}4 . \\
\text { Grain Distribution } \\
(0 / 00)\end{array}$} \\
\hline & & 恶 & 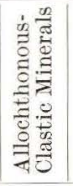 & 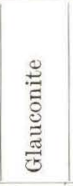 & $\stackrel{8}{E}$ & 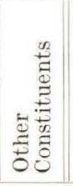 & 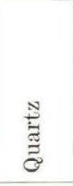 & 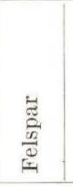 & $\stackrel{\Xi}{ٍ}$ & 离 & 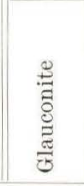 & 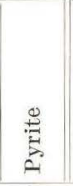 & 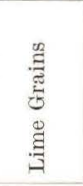 & 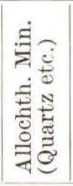 & 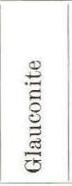 & $\stackrel{5}{5}$ & 焉 \\
\hline \multirow[t]{5}{*}{1} & $0.02-0.05$ & 85.9 & 0.4 & 12.5 & 1.2 & tr. & 93.1 & 2.1 & 4.8 & - & 91.1 & 8.9 & 52.7 & 0.3 & 7.6 & 0.7 & - \\
\hline & $0.05-0.10$ & 89.9 & 1.0 & 8.5 & 0.3 & 0.3 & 89.4 & 10.6 & tr. & - & 96.8 & 3.2 & 169.8 & 1.9 & 16.1 & 0.5 & 0.5 \\
\hline & $0.1-0.2$ & 90.0 & 2.8 & 6.7 & 0.4 & 0.1 & 99.0 & 1.0 & - & - & 93.7 & 6.3 & 373.1 & 11.7 & 27.6 & 1.8 & 0.3 \\
\hline & $0.2-0.5$ & 38.5 & 26.7 & 23.5 & 10.5 & 0.8 & 97 & 3 & - & 一 & 69.1 & 30.9 & 13.3 & 9.2 & 8.1 & 3.6 & 0.3 \\
\hline & $0.5-1.0$ & 79.0 & 0.6 & 6.6 & 一 & 13.8 & - & - & 一 & 一 & 100 & - & 47.5 & 0.4 & 4.0 & - & 8.4 \\
\hline \multirow[t]{5}{*}{5} & $0.02-0.05$ & 78.5 & 6.8 & 11.8 & 2.8 & 0.1 & 84.9 & 8.2 & 6.0 & 0.9 & 81.0 & 19.0 & 22.5 & 1.9 & 3.4 & 0.8 & - \\
\hline & $0.05-0.10$ & 81.3 & 11.0 & 7.1 & 0.4 & 0.2 & 91.6 & 7.3 & 0.4 & 0.7 & 94.7 & 5.3 & 81.7 & 11.1 & 7.1 & 0.4 & 0.2 \\
\hline & $0.1-0.2$ & 82.3 & 9.9 & 6.5 & 1.0 & 0.3 & 95.9 & 4.1 & - & tr. & 87.4 & 12.6 & 197.7 & 23.8 & 15.7 & 2.3 & 0.7 \\
\hline & $0.2-0.5$ & 69.0 & 16.6 & 7.7 & 2.0 & 4.7 & 95.2 & 4.8 & - & - & 79.0 & 21.0 & 45.2 & 10.9 & 5.1 & 1.3 & 3.0 \\
\hline & $0.5-1.0$ & 66.3 & 13.9 & 一 & - & 19.8 & 99.1 & 0.9 & - & - & - & - & 84.4 & 17.7 & - & 一 & 25.2 \\
\hline \multirow[t]{5}{*}{10} & $0.02-0.05$ & 73.5 & 3.4 & 16.2 & 6.8 & 0.1 & 91.5 & 3.4 & 5.1 & - & 70.4 & 29.6 & 68.0 & 3.1 & 15.0 & 6.3 & 0.1 \\
\hline & $0.05-0.10$ & 84.3 & 2.1 & 12.0 & 1.6 & & 96.2 & 2.3 & 1.5 & 一 & 88.2 & 11.8 & 242.8 & 6.0 & 34.6 & 4.6 & - \\
\hline & $0.1-0.2$ & 79.3 & 0.9 & 18.3 & 0.2 & 1.3 & 97 & 2 & 1 & - & 98.8 & 1.2 & 229.0 & 2.6 & 52.8 & 0.6 & 3.8 \\
\hline & $0.2-0.5$ & 55.0 & 3.8 & 40.6 & 0.6 & - & 100 & 一 & - & - & 98.5 & 1.5 & 23.4 & 1.6 & 17.3 & 0.3 & - \\
\hline & $0.5-1.0$ & $61.2 *$ & 1.6 & 35.1 & 一 & 2.1 & - & - & - & - & 100 & - & 7.3 & 0.2 & 4.2 & - & 0.2 \\
\hline \multirow[t]{5}{*}{11} & $0.02-0.05$ & 77.5 & 9.4 & 7.9 & 4.3 & 0.9 & 89.1 & 4.2 & 5.9 & 0.8 & 64.9 & 35.1 & 100.7 & 12.2 & 10.3 & 5.5 & 1.2 \\
\hline & $0.05-0.10$ & 86.0 & 2.0 & 7.3 & 2.6 & 2.1 & 96.6 & 3.4 & $\ldots$ & - & 73.4 & 26.6 & 227.3 & 5.3 & 19.2 & 7.0 & 5.5 \\
\hline & $0.1-0.2$ & 81.3 & 0.2 & 15.1 & 1.9 & 1.5 & 96.4 & 3.6 & - & - & 88.8 & 11.2 & 49.6 & 0.1 & 9.2 & 1.2 & 0.9 \\
\hline & $0.2-0.0$ & $63.7^{*}$ & 3.6 & 29.6 & 2.8 & 0.3 & 100 & 一 & - & - & 91.4 & 8.6 & 1.0 & 0.1 & 0.4 & 一 & - \\
\hline & $0.5-1.5$ & $99.7 *$ & - & 0.1 & - & 0.2 & - & - & - & 一 & 100 & - & 0.9 & - & - & - & - \\
\hline \multirow[t]{5}{*}{ V } & $0.02-0.05$ & 59.1 & 28.6 & 7.0 & 2.3 & 3.0 & 93.3 & 4.8 & 1.9 & - & 75.5 & 24.5 & 79.9 & 38.7 & 9.5 & 3.1 & 4.0 \\
\hline & $0.05-0.10$ & 76.9 & 7.6 & 10.7 & 1.6 & 3.2 & 95.1 & 4.9 & - & 一 & 86.7 & 13.3 & 125.6 & 12.4 & 17.4 & 2.7 & 5.2 \\
\hline & $0.1-0.2$ & 75.0 & 0.4 & 18.1 & 3.2 & 3.3 & - & - & - & - & 84.8 & 15.2 & 26.6 & 0.1 & 6.4 & 1.2 & 1.2 \\
\hline & $0.2-0.5$ & $78.5^{*}$ & 1.2 & 4.7 & 15.4 & 0.2 & 95.2 & 4.8 & - & - & 23.6 & 76.4 & 1.6 & 0.1 & 0.1 & 0.3 & - \\
\hline & $0.5-1.0$ & $99.7 *$ & 0.2 & - & 0.1 & 一 & - & 一 & - & 一 & 一 & 100 & 1.0 & 一 & - & - & - \\
\hline \multirow[t]{5}{*}{ VI } & $0.02-0.05$ & 58.8 & 29.6 & 3.9 & 6.0 & 1.7 & 93.6 & 3.2 & 2.3 & 0.9 & 39.6 & 60.4 & 131.2 & 66.0 & 8.7 & 13.4 & 3.8 \\
\hline & $0.05-0.10$ & 73.2 & 5.0 & 10.7 & 8.5 & 2.6 & 93.3 & 6.0 & 0.7 & - & 55.6 & 44.4 & 64.9 & 4.4 & 9.5 & 7.6 & 2.3 \\
\hline & $0.1-0.2$ & 59.8 & 2.9 & 17.1 & 17.9 & 2.3 & 98.5 & 1.5 & - & - & 48.8 & 51.2 & 5.3 & 0.2 & 1.5 & 1.6 & 0.2 \\
\hline & $0.2-0.5$ & $67.8^{*}$ & 5.9 & 3.5 & 22.6 & 0.2 & 96.4 & 3.6 & - & - & 13.4 & 86.6 & 1.1 & 0.1 & 0.1 & 0.4 & - \\
\hline & $0.5-0.1$ & $94.0 *$ & 4.2 & & 1.8 & - & & 一 & - & - & - & 100 & 0.7 & - & $\longrightarrow$ & 一 & 一 \\
\hline
\end{tabular}

The glauconite-pyrite ratio (third column) is subject to considerable, irregular variations from grain size to grain size, corresponding to the irregular distribution of the pyrite. As regards the finer grains, 
however, it is evident that the quantity of pyrite is the higher, the finer are the grains. Considered from stratum to stratum, there is a distinct variation from deposits rich in glauconite, poor in pyrite, at the bottom of the series to deposits poor in glauconite, rich in pyrite at the top.

The grain distribution of the various minerals. The fourth column of Table 3 shows the quantities of the different components, calculated in $\%$ by combining the counts (Column 1) and the mechanical analyses. The results are reproduced in distribution curves indicating the distribution of the components which have been more or less transported and sorted, viz. the lime grains, the allochthonous-clastic components, and the glauconite grains (Fig. 11). The table and curves show that the lime grains and the glauconite are the same in their grouping, their maxima being in the same grain size. This means that the glauconite grains have been subjected to the same sorting processes as the lime grains. CAYEuX has drawn attention to the fact that in a sediment the glauconite has the same grain size as the other clastic components, which is a sign that the glauconite has been transported (CAYEux 1897). Accordingly, the glauconite grains in the rocks must be regarded as anchi-autochthonous.

The allochthonous-clastic minerals, on the other hand, group differently in the lower and in the upper samples. In the former (1, 5 and 10) they have a maximum lying in almost the same grain size as the lime grains and the glauconite grains (and in Sample 5 a secondary maximum in the finest part of the gravel group). In the upper samples (11, V and VI) we find no such maximum, although the lime grains and the glauconite grains have one, but the quantity of the allochthonous-clastic components rises as we come to finer and finer grains.

Consequently, in the Vestre Gasværk series it is possible to distinguish two types of sediments: a lower one characterised by the combination lime sand - glauconite sand - quartz sand, and an upper one with the combination lime sand - glauconite sand — terrigenous clay.

\section{The Phosphorites.}

The phosphorites from the Vestre Gasværk series are irregularly shaped concretions of a size from 1 to $5 \mathrm{~cm}$. Two types are distinguishable, one consisting of a very fine and homogeneous mass, the fracture being even and smooth, another of a much coarser nature.

In the fine type the microscope makes it possible to distinguish very fine lime grains as an intermixture everywhere, as well as a quantity of fine spicules with a diameter round about $0.01 \mathrm{~mm}$. I have been unable to determine the exact nature of these spicules, most of which 

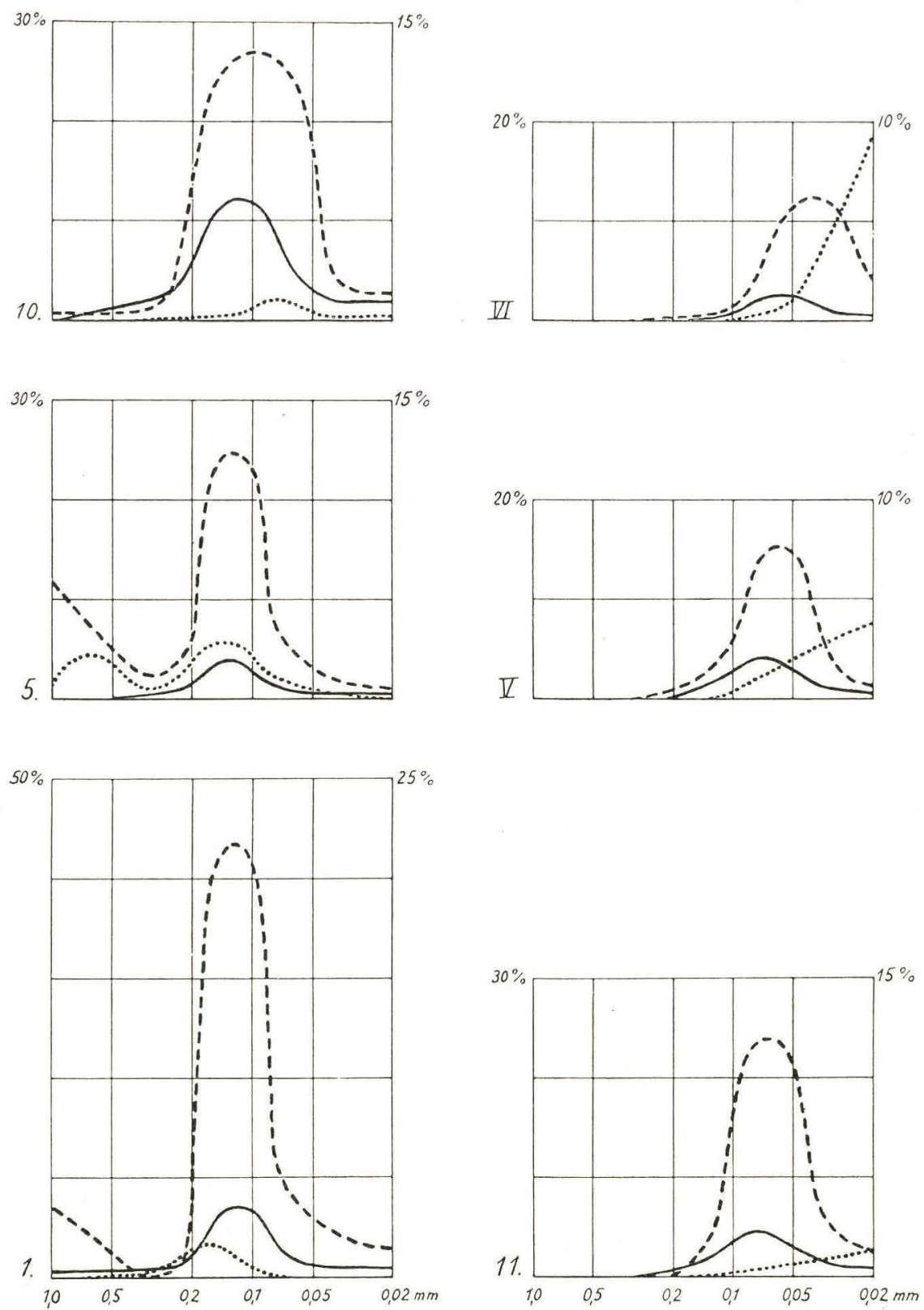

Fig. 11. Distribution curves, Vestre Gasværk. The area bounded by the curve, two arbitrary ordinates and the abseissa-axis represents the percentages of grains in a fraction, in which the abscissae corresponding to the two ordinates indicate the lower and the upper grain size limit. The percentages indicated apply to fractions in which the lower size limit is half the upper one. The percentage on the left applies to the lime sand, that on the right to glauconite and allochthonous sand.

- lime sand; glauconite; allochthonous sand (quartz etc.). 
contain a single calcite crystal, but there is a possibility that they are sponge spicules.

The coarse phosphorite contains very large quantities of all the components of the greensand and must almost be regarded as being phosphoritised greensand (Plate 1 Fig. 4). The natural components of greensand: glauconitized and pyritized lime grains, glauconite grains and quartz, apparently lie in their natural position. The grains are covered with a thin skin of phosphorite, but as a rule the large cavities are not infilled, so that the rock is porous. In certain areas, however, the phosphorite mass infills all the pores between the grains. Furthermore, the phosphorite to a very great extent has spread at the expense of the calcite, and here and there has completely replaced it. In these cases the place of the lime grains is marked by the presence of fine pyrite grains and glauconite pigment, and it can also be recognized by small differences in the colour of the phosphorite. The only mineral to suffer by the phosphoritising is the calcite; both pyrite and glauconite remain in their original form. The manner in which the phosphorite surrounds the lime grains, and the complete absence of secondary calcite, show that the phosphoritising has proceeded at an early stage, after the glauconitizing but prior to the commencing cementation observable on the grains in the rock in which the phosphorites occur.

\section{The Greensand Pebbles.}

The hard nodules occurring in the form of pebbles in the marl are usually much more sandy than the marl. On most cases they are subangular, and in compact rock samples it can be seen that the stratification in the "pebbles" is accidentally orientated (Fig. 7, p. 39). This all shows that they must be regarded as foreign elements in the marl.

If the pebbles are treated with dilute hydrochloric acid they do not break down as the greensand samples cemented by calcite do; the emanation of carbonic acid gas stops after a short time and the acid ceases to have any effect. An examination of the rock in thin sections shows that this is due to the rocks being more or less silicified.

It can be seen in the thin sections that the rock is built up of brownish, impure lime grains lying in a brownish, silicified matrix. The lime grains are rarely glauconitized, more frequently being more or less pigmented by finely distributed pyrite. There are relatively few glauconite grains, whereas pyrite concretions are fairly frequent. Besides concretions of irregular form there are some in the shape of sponge spicules, and also others whose triangular shape reveals that they were formed in diatoms. Untransformed brownish sponge spicules are not uncommonly met with in the rock. The matrix is brownish and in certain areas mostly consists 
of undifferentiated brownish opal, whereas in other areas it contains abundant calcareous mud besides opal.

The rock is difficult to subdivide. Nevertheless, by crushing and treating with dilute hydrochloric acid and ammonia I have been able to divide the rock so much that I was able to count the proportion of glauconite to pyrite grains. The count was made of grains with a diameter round about $0.05 \mathrm{~mm}$, and the results are given in the following table showing the glauconite percentage of glauconite + pyrite. For purposes of comparison I have also shown the glauconite percentages in the over and underlying marl.

\begin{tabular}{|c|c|c|c|c|c|}
\hline & Depth & Rock & $0.02-0.05 \mathrm{~mm}$ & ea. $0.05 \mathrm{~mm}$ & $0.05-0.10 \mathrm{~mm}$ \\
\hline$-5.6 \mathrm{t}$ & to $-5.8 \mathrm{~m}$ & Marl, VI. & 40 & - & 56 \\
\hline-5.6 &,-5.8, & Silic. nodule & & 22 & - \\
\hline-6.2 &,-6.5, & , & - & 67 & - \\
\hline-6.5 &,$\quad-6.8$, & , & & 24 & \\
\hline-6.5 &,-6.8, & , , & - & 27 & - \\
\hline-6.5 &,-6.8, & Marl, V. & 75 & - & 87 \\
\hline
\end{tabular}

The table shows very distinctly that the nodules as a rule are much poorer in glauconite than the marl in which they lie.

For comparison purposes the rocks from the dredging of Kongedybet have been examined. Paleocene was found at two places in this locality: about 600 metres and about 1300 metres from the shore off the street Italiensvej.

At the former place there was everywhere a very hard rock at $-6.35 \mathrm{~m}$, and under it dark marl containing harder nodules. The hard rock is reported to lie in a continuous bed, about $8 \mathrm{~cm}$ thick, over the marl, and at about the same depth shallow borings have revealed the presence of a hard layer further away from the shore. The hard rock is a finegrained, silicified sandstone corresponding exactly to the hard nodules in the Vestre Gasværk series.

At $1300 \mathrm{~m}$ from the shore, dark-grey marl was found at -7.10 to $-7.50 \mathrm{~m}$. The rock is the same as at the foregoing place, but contains no harder areas.

On the whole the marl from Kongedybet has the same structure as that from Vestre Gasværk. The only demonstrable difference is a large quantity of pyrite, which to a great extent is present in the form of triangles and disk-shaped bodies which often are built up of small spheres. Subordinately the pyrite is also found as sponge spicules. The high pyrite content and the large quantity of diatoms connect the marl more closely with the Kerteminde marl than the other rocks in Copenhagen. 
The glauconite and pyrite counts gave the following result (like the preceding table, the one below gives the glauconite percentage of glauconite + pyrite).

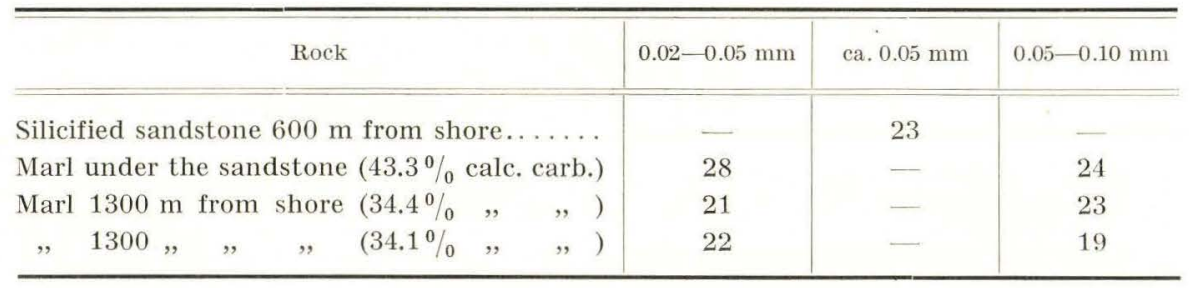

Here, then, is distinct agreement between the glauconite percentage in the hard stratum and that in the marl, and, what is more, the glauconite percentage corresponds very well with what was found in the nodules of the Vestre Gasværk marl. It is therefore probable that the hard lumps from Vestre Gasværk came from a more sandy layer belonging to a pyritic marl series, similar to that in Kongedybet.

\section{Sundkrogen.}

In this locality the Paleocene was found when deepening the harbour basin "Sundkrogen", and the conditions have already been described by Harder (1922) and by Rosenkrantz (1924). During excavations there were found dark marl and grey sandy marl. The situation and the bedding of the strata were elucidated by borings made in three places down into or through the Paleocene. The situation of the three borings will appear from their distance from the west and south quays of the basin:

Boring A: $90 \mathrm{~m}$ from West Quay, in the foundation excavations for the South Quay.

Boring 1: $90 \mathrm{~m}$ from West Quay, $30 \mathrm{~m}$ from South Quay. Boring 2: $5 \mathrm{~m}$ from West Quay, $10 \mathrm{~m}$ from South Quay.

In addition to HARDER's and Rosenkrantz's descriptions I have examined the boring reports made by the engineers and the samples from the borings. Among the boring samples only two rock types are distinguishable: greensand and marl. The greensand is characterised by being very sandy, by a distinctly greenish colour and by a high glauconite content, the marl by a lower sand content, brownish-grey colour and a high pyrite content, but little glauconite.

The following particulars refer in the main to the boring samples and the reports. The determinations of the calcium carbonate content are new. The depths are given in metres below the mean sea level. 
Boring A.

Boring from depth $10.8 \mathrm{~m}$, in dark marl.

- 12.0 Sample of marl $57.3 \%$ calcium carbonate

$-12.3 \quad, \quad, \quad, \quad 59.0 \% \quad, \quad, \quad$,

$-12.6 \quad, \quad, \quad, \quad, \quad 59.4 \% \quad, \quad, \quad$,

$-12.8 \quad, \quad, \quad, \quad, \quad 55.5 \% \quad, \quad, \quad$,

$-13.0 \quad, \quad$, greensand $70.1 \% \quad, \quad$,

$-13.3 \quad, \quad, \quad, \quad, \quad 69.6 \% \quad, \quad$,

Continued boring in greensand to $14.5 \mathrm{~m}$ (Rosenkrantz).

Boring 1.

Boring from depth $10.2 \mathrm{~m}$ in dark marl.

-11.0 Sample of marl $\quad 39.0 \%$ calcium carbonate

$-12.0 \quad, \quad$ " , $\quad 56.1 \% \quad, \quad$,

$-13.0 \quad, \quad$, greensand $64.2 \% \quad, \quad, \quad$,

$-14.0 \quad, \quad, \quad, \quad, \quad 77.0 \% \quad,, \quad$,

$-15.0 \quad, \quad$, greensand with numerous glauconitized shells.

At 15.5 hard green sandstone down to $16.0 \mathrm{~m}$ (according to report). Washed samples from this depth show a rather impure mixture of glauconitized calcareous shells, greensand and Quaternary material.

Boring 2.

Boring from depth $10.9 \mathrm{~m}$.

-11.5 Sample of greensand $61.5 \%$ calcium carbonate

$-12.0 \quad, \quad, \quad, \quad, \quad 72.8 \% \quad, \quad, \quad$,

$-13.0 \quad, \quad, \quad, \quad 71.5 \% \quad, \quad, \quad$,

- 14.0 Sample contains a mixture of glauconitized calcareous shells and Danian flint.

At $14.2-14.6 \mathrm{~m}$ flint. Green and white material came up when the pipe was put down from 14.0 to $14.4 \mathrm{~m}$. The limestone was found at $-14.82 \mathrm{~m}$ (according to report).

According to Rosenkrantz there are in Boring A:

About $1.2 \mathrm{~m}$ dark clay

,. $\quad 0.7 \mathrm{~m}$ brown fine sand

, $\quad 1.8 \mathrm{~m}$ greensand

$(12.7-14.5)$

Judging from the samples, however, the upper boundary of the greensand must be put about $0.2 \mathrm{~m}$ downwards, so that the series is:

10.8-12.9 marl, more sandy at the bottom.

12.9-14.5 greensand.

According to Rosenkrantz and Harder, Boring 1 contains:

About $2.0 \mathrm{~m}$ dark clay

,. $\quad 0.8 \mathrm{~m}$ brown fine sand

,. $\quad 2.0 \mathrm{~m}$ clayey greensand

" $\quad 1.1 \mathrm{~m}$ greensand limestone

$(15.0-16.1)$ 
The boring report states that the greensand limestone only begins at $15.5 \mathrm{~m}$. The sample from $13.0 \mathrm{~m}$ is typical greensand, and, as RosenKRANTZ and HARDER put the boundary between greensand and fine sand at this depth, this sample undoubtedly comes from the uppermost part of the greensand. If we take it that the strata in Boring 1

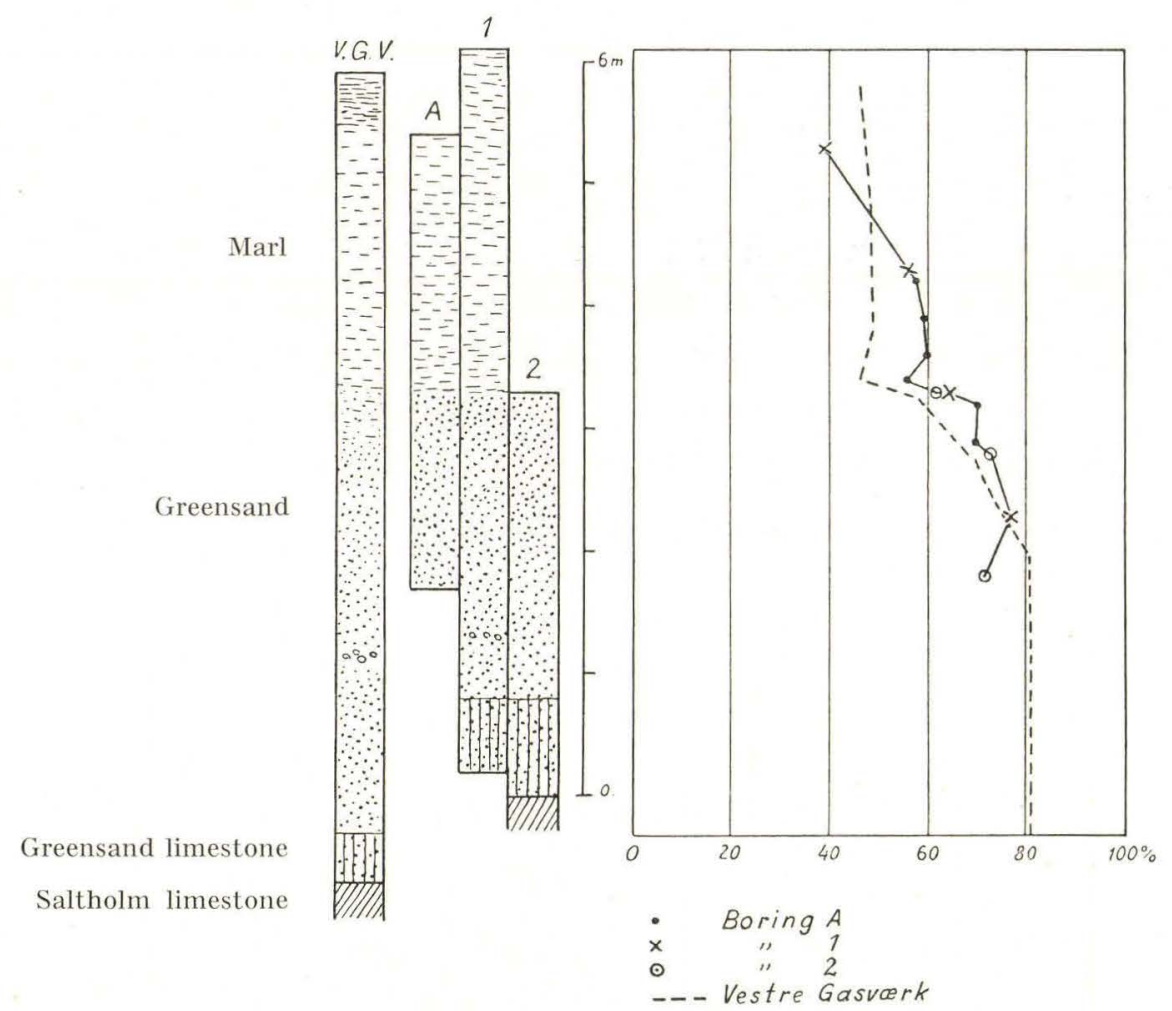

Fig. 12. Sundkrogen. Calcium carbonate content of the samples from the three borings combined by means of the rock types. For comparison the calcium carbonate content of the Vestre Gasværk series.

are about $0.1 \mathrm{~m}$ deeper than in Boring $\mathrm{A}$, there is good agreement between the two borings both as to rock and as to calcium carbonate content.

According to Rosenkrantz and Harder, Boring 2 contains:

$$
\begin{array}{cl}
\text { About } & 2.5 \mathrm{~m} \text { greensand } \\
, & 0.8 \mathrm{~m} \text { greensand limestone } \\
& \text { Saltholm limestone. }
\end{array}
$$

Flint occurs from about $14 \mathrm{~m}$ down, which shows that the strata there have been disturbed. The uppermost sample (from -11.5) is somewhat finer than the others, which indicates that it comes from the upper 
part of the greensand. If we take it that it came from the boundary between greensand and marl, we get the same thickness for the incoherent greensand in Boring 1 and Boring 2. Accordingly, the strata in Boring 2 must presumably lie about $1.5 \mathrm{~m}$ higher than in Boring 1 .

By combining the three borings we arrive at the section indicated in Fig. 12, consisting of

about $2.8 \mathrm{~m}$ dark marl, more sandy at the bottom.

, $\quad 2.5 \mathrm{~m}$ greensand, very coarse at the bottom and with glauconitized Danian fossils.

, $\quad 0.8 \mathrm{~m}$ greensand limestone.

Saltholm limestone.

As far as one can conclude from the rather impure samples, the greensand and greensand limestone are quite of the usual Copenhagen type. The samples of the greensand limestone consist almost exclusively of impure crumbled rock, and there are no samples of any strongly cemented rock. This might mean that the rock is not so much hardened as in the other localities.

The marl very strongly resembles the marl from Vestre Gasværk, though some of the samples contain much larger quantities of pyrite. As was the case with the rocks from Kongedybet, the pyrite to a great extent is present in the form of triangular or disk-shaped concretions formed of small spheres. Accordingly we may assume that the marl in Sundkrogen and Kongedybet was formed in water that was rather poor in oxygen, under physical and chemical conditions greatly resembling those under which the Kerteminde marl was deposited.

\section{Lellinge.}

At Lellinge, about 6 kilometres west of Køge, the river Køge Aa has cut through the Quaternary down into the Paleocene, represented by a greensand deposit barely 9 metres thick. The greensand is exposed along a stretch of more than 600 metres and is visible in the banks with a thickness of up to $2 \frac{1}{2}$ metres. East of the Paleocene is hardened bryozoan limestone from the Danian. This limestone, which formerly was used as building stone, was exposed at the locality "Limgravene" (lime pits), but is now overgrown.

There are marked differences in the development of the Paleocene rocks. There are a fairly loose green sandstone, greensand-stone, a hard, calcite-cemented rock known as greensand limestone, and, subordinately, a silicified, flinty rock, chert. Close to the eastern bound- 
ary of the outcrop there is a subordinate bed, 25-30 $\mathrm{cm}$ thick, of dark sandy marl with hard nodules.

The stratigraphical position was worked out by JoHnstrup in 1875 , when he made 5 borings, four of them reaching down into the underlying limestone. Their position is shown by the map Fig. 13. For these four borings the cotes for the boundary between Cretaceous and Paleocene lie at the following depths:

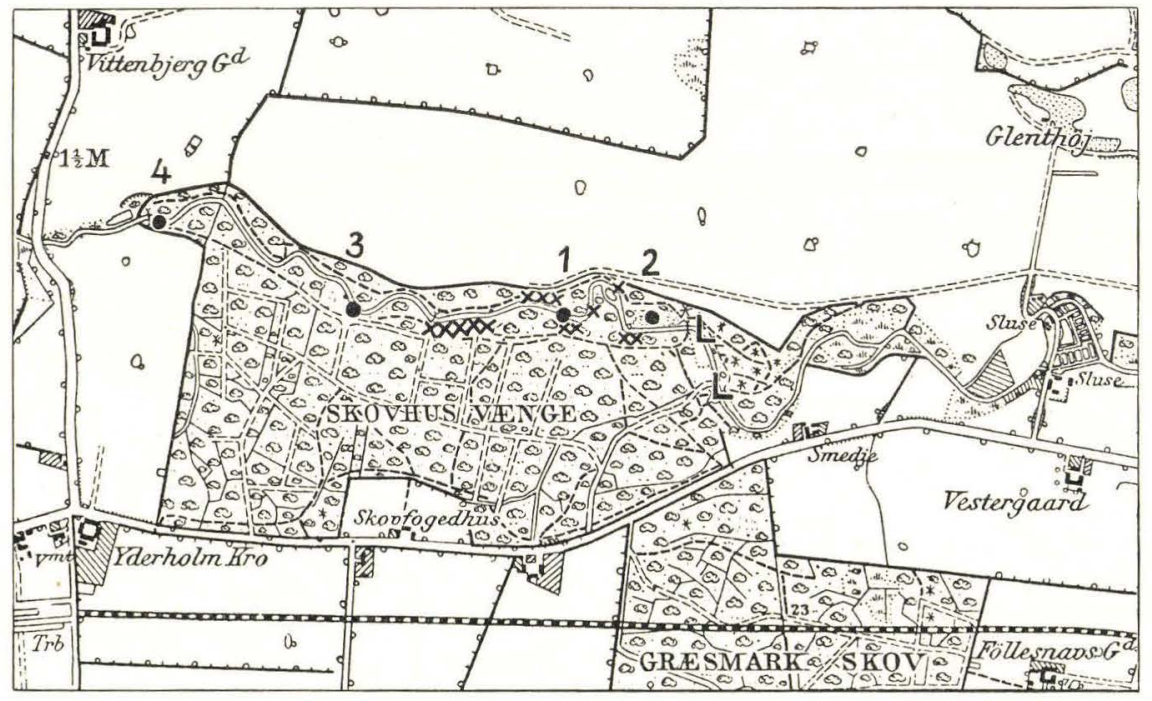

Fig. 13. Map of the Lellinge locality (1:20000). 1-4 Johnstrups borings; $x x \times$ Paleocene visible 1935; L Saltholm limestone visible 1935.

\begin{tabular}{|c|c|c|c|c|c|}
\hline ole No & & 4 & 3 & 1 & 2 \\
\hline $\begin{array}{l}\text { Paleocene } \\
\text { Cretaceous }\end{array}$ & cot & $+10.9 \mathrm{~m}$ & $+8.2 \mathrm{~m}$ & $+8.3 \mathrm{~m}$ & $+9.3 \mathrm{r}$ \\
\hline
\end{tabular}

Thus the boundary is almost horizontal, and presumably the strata are undisturbed (JOHNSTRUP 1876).

The dark clayey deposit is exposed near to JoHnstrup's Borehole No. 2. At a place between Borehole No. 1 and No. 2 I have measured the following section in the bank above the river bed:

About $30 \mathrm{~cm}$ greensand-stone, partly weathered to yellowish-green sand, with harder nodules.

" $10 \mathrm{~cm}$ partly greensand-stone, partly incoherent greenish-grey sand.

", $25 \mathrm{~cm}$ dark grey, sandy marl, containing hard, subangular nodules of greensand-stone.

, $10 \mathrm{~cm}$ hard, silicified greensand.

,. $70 \mathrm{~cm}$ greensand-stone. 
As the boundary between the Paleocene and the Cretaceous in Borehole No. 2 lies about $3 \mathrm{~m}$ under the river bed, and Grönwall (1910) states that the dark marl a little more to the west can be seen just on a level with the surface of the water, the bed of dark grey marl apparently lies 3-4 $\mathrm{m}$ above the lower boundary of the Paleocene. This conforms well with Johnstrup's section from Borehole No. 1, where there were found:

Borehole No. 1. $1.3 \mathrm{~m}$ greensand deposits.

$0.5 \mathrm{~m}$ dark marl.

$3.3 \mathrm{~m}$ greensand deposits.

Hardened bryozoan limestone.

In Johnstrup's Borehole No. 5 there was a similar marl bed, overlain by almost $4 \mathrm{~m}$ of greensand:

Borehole No. 5. $6.9 \mathrm{~m}$ Quaternary deposits.

$3.9 \mathrm{~m}$ greensand deposits.

$0.2 \mathrm{~m}$ dark marl.

$0.8 \mathrm{~m}$ greensand deposits.

A number of Johnstrup's boring samples have been preserved. As a rule they are pure and fairly large, and give a lot of information about the rocks. In most cases they are so coherent that they can be ground down to thin sections, whereas only very few are so incoherent that they lend themselves to elutriation.

Apart from differences due to silicification or cementation by calcite, the rocks on the whole are very much the same, both as to size of grain and as to petrographic composition. One or two samples from the lowest strata are, however, somewhat coarser than is the rule. This applies especially to Sample 11, Borehole No. 3 (sample just over the Cretaceous) which consists of coarse and more or less unsorted material and represents the bottom of the Paleocene at Lellinge. Sample 10, Borehole No. 3 (about $1.6 \mathrm{~m}$ over the Cretaceous) is also rather coarse; it is so incoherent that I was able to make an elutriation analysis followed by a petrographic analysis of it. In Borehole No. 2 the samples near the bottom of the Paleocene are also rather coarser than usual.

\section{Earlier Petrographic Investigations.}

Both Forchinamer (1849) and Johnstrup (1876) made chemical analyses of the rocks at Lellinge. In the greensand-stone they found about $57-80 \%$ calcium carbonate and the rest mostly sand, clay and 
green silicates; in the compact greensand limestone they found 89-90\% calcium carbonate.

A more detailed petrographic investigation was made by RøRDAM in 1897 .

Like Forchinmmer and Johnstrup, Rordam distinguishes between an incoherent variety, greensand-stone, and a hard, calcite-cemented variety, greensand limestone.

Greensand limestone consists, according to RøRDAM, to a great extent of organic remains (mostly foraminifera, subordinately bryozoa) cemented by calcite. There are also numerous spherical bodies of uncertain origin. Frequently they have a diameter of about $0.07 \mathrm{~mm}$ and usually are full of calcite; more rarely they are empty. Besides these calcareous ingredients, which form about $90 \%$ of the limestone, there are remains of green siliceous sponges (lithistides), diatoms (??) and quartz splinters, rarely exceeding $0.1 \mathrm{~mm}$ in diameter.

The greensand-stone, according to RøRDAM, contains $60-80 \%$ calcium carbonate, partly in the form of foraminifera, partly as calcite infilling. In the section it can be seen that the calcareous particles lie in a greyish, amorphous mass. The residue after treating with dilute hydrochloric acid consists of amorphous silica and small quantities of sponge spicules and quartz. The rock is thus impregnated with undifferentiated silica, which presumably forms the greyish amorphous mass in which foraminifera, sponge spicules and quartz grains lie.

In his observations on the greensand-stone RøRDAм finds support for his theory of the formation of flint in the Cretaceous limestones. He considers that flint is formed as a steadily advancing metamorphosis from calcite, through opal and chalcedony to quartz. The flint forms as concretionary nodules through the constant supply and deposition of silica at the expense of the calcite. The greensand-stone is still at a primary stage, in which the differentiation of the silicic and calcareous deposits to separate limestone and flint beds has not yet proceeded.

Of the dark marl, which Forchнамmer and Rørdam erroneously assume lies over the greensand deposits, the latter has a mechanical analysis. His results are:

$$
\begin{array}{rr}
\text { over } 2.0 \mathrm{~mm} & 7.0 \% \\
1.0-2.0 \mathrm{~mm} & 3.0 \% \\
0.05-1.0 \mathrm{~mm} & 47.6 \% \\
\text { under } 0.05 \mathrm{~mm} & 42.4 \%
\end{array}
$$

The rock contains numerous foraminifera, mostly with their cavities infilled, partly with calcite, partly with an amorphous, dark-brown mass. Many calcite grains are also seen, but only few quartz grains, and these of very small size, as well as a few remains of siliceous sponges. 
In addition there are yellowish-brown aqueous silicic acid and zeolithic constituents.

\section{Petrographic Description of the Rocks.}

\section{The Substratum.}

From Johnstrup's Borings No, 2, 3 and 4 we have samples of the limestone immediately underlying the Paleocene. The samples from Boring 3 consist of a rather incoherent and very coarse bryozoan fragment limestone, containing small quantities of glauconite and pyrite as well as a few small irregularly formed quartz grains. From Boring 2 and 4 there is more or less glauconitized, considerably hardened and compact limestone, which, as far as can be judged, prior to hardening has been of a character resembling that of the limestone from Boring 3 . Sections of the hard limestone display numerous bryozoan fragments, foraminifera, and other organic calcareous fragments, lying in a calcareous cement which in most cases is very fine grained, and more rarely forms a coarser mosaic. Glauconite occurs mainly as pigment in some of the organisms, only rarely as rounded grains. Pyrite occurs sporadically throughout the entire rock, both in the shells and in the groundmass, and is also present as a fine pigment.

The boring samples from greater depths consist of normal bryozoan limestone and Danian flint.

In the district east of Lellinge, towards Køge, the substratum to the Quaternary deposits is limestone of the youngest Danian, viz. bryozoan limestone, which is overlain by a shelly limestone, the lower part of which is fine grained, whereas the upper part consists of lime-gravel containing large quartz grains and grains of glauconite. The substratum to the Paleocene at Lellinge almost corresponds to the lower part of the shelly limestone but, as stated, is considerably hardened. Thus it is clear that the Upper Danian strata containing lime-gravel have been disintegrated by the transgression of the Paleocene sea over the Lellinge district.

\section{The Consolidated Rock Types of the Paleocene.}

The Paleocene basal deposit (Johnstrup's Sample 11, Boring 3). On examining the boring samples in the Mineralogical Museum in Copenhagen it was found that only one sample came from the bottom of the Paleocene deposits. It is from Boring 3 , and was taken at a depth of $20^{1} / 6$ feet. As Johnstrup states that the thickness of the greensand is 20 feet, it is presumable that the sample actually represents 
the basal deposit of the Paleocene, and this assumption is confirmed by the fact that the sample is the coarsest and least sorted of all the boring samples. The rock was examined in thin section.

The bulk of the rock is a dense conglomeration of large and small fragments of various shells. It is difficult to pick out a main grain size, as the fragments are very irregular in form and greatly varying in size, whilst in colour and structure they are often very little conspicuous in the matrix of the rock. Still, a large part of the fragments seem to have a diameter of between 0.2 and $0.5 \mathrm{~mm}$. Larger or smaller parts of bryozoan stems form the greater part of the coarser shell fragments, whilst foraminifera are very frequent among the finer ones. The shell fragments, which have a pale, dirty-brown colour, are sometimes recrystallised to some extent, so that the original structure has been lost and has been replaced by a fine aggregate structure. Some of the lime grains are slightly glauconitized, but more frequently they contain pyrite in the form of small concretions or fine grains. Glauconite also occurs as an infilling in foraminiferal chambers and bryozoan chambers and in the cavities of sponge spicules. There are also some lobate or round glauconite grains with a diameter of about $0.1 \mathrm{~mm}$. Of allochthonous-clastic constituents there are quartz and a few grains of felspar, mostly sharp-edged isodiametric grains having a diameter of about $0.05-0.1 \mathrm{~mm}$. In the section it was also possible to observe a quartzite fragment in which the glauconite has penetrated the boundaries between the quartz grains. Here and there are sponge spicules consisting of opal, but their cavities may, as already mentioned, be infilled with glauconite.

The matrix is very fine grained and contains numerous fine calcite particles and a few coccoliths. Judging from all the circumstances the matrix consists of unhardened, argillaceous, calcareous mud. On the shell fragments there is secondary calcite deposited in the form of very fine crystals, which shows that a cementation has been started.

The type described has several features which show that it has undergone only few changes after it was deposited. First and foremost, there is the fact that the mud is unhardened, and furthermore there are the untransformed sponge spicules. All the other rock samples I have had an opportunity of examining contrast with this type. A feature common to all these rocks is their great wealth of sponge spicules, which are present in such large numbers that they can bear comparison with the lime sand constituents. According to the secondary processes that have occurred the rocks may be divided into three types:

1. Greensand-stone, in which the sponge spicules are decomposed, whereas the rock has been impregnated with silica. 
2. Chert, in which the sponge spicules have been transformed into chalcedony, whereafter silicification has continued.

3. Greensand limestone, a compact, hardened rock cemented by calcite.

1. Greensand-stone. The first-named type is very closely related to the rock which I have already described. One difference is a greater uniformity in the grain size of the calcareous particles, as their diameter mostly lies round about $0.2 \mathrm{~mm}$. Furthermore, it is characteristic that a great part of the sponge spicules have been decomposed, and their place is marked by holes in the rock. The holes have exactly the form of the spicules, i. e. of straight needles, and in cross section they are circular, with a diameter in the vicinity of $0.06 \mathrm{~mm}$. RøRDAM writes that the sponge remains in the greensand-stone have a clear, grass-green colour and the shape of needles, distorted branches or irregular, branchiate lumps, but this must be a mistake. As with the greensand limestone in Copenhagen he must have confused the glauconitic impregnation masses resulting from treating the glauconitized calcareous grains with acid, with sponge spicules. It is true that there are glauconitic casts of spicule cavities, but they are not very numerous and almost always of a most regular needle shape.

Like the other rocks which do not come from the lowest parts of the series, the greensand-stone on the whole is richer in glauconite than the basal stratum, there being both more glauconite grains and a more general glauconitizing of the lime grains.

The matrix in which the arenaceous constituents lie is, in all the coherent samples of greensand-stone, completely permeated with an isotropic, almost clear substance with a low refractive index. A comparison with RORDAM's analyses and with the substance forming the sponge spicules shows that this is an opal substance. Therefore the characteristic feature of the greensand-stone is that many of the spicules are decomposed and that the silica has been laid down as an impregnation in the rock.

2. Chert. In the greensand-stone there occur subordinate, irregularly bounded portions, silicified so that a flinty rock has appeared which passes smoothly into the normal greensand-stone.

In the least transformed parts of the rocks only the spicules have been transformed into chalcedony, whereas the rest of the rock is preserved as ordinary greensand-stone (Plate 2, Fig. 3). In such rocks one obtains a very clear impression of the form of the sponge spicules. Most frequently they are, as stated, exactly straight tubes, the eavities of which are sometimes infilled with a brownish, presumably argillaceous mass, more rarely with glauconite. The diameter of these tubes mostly lies in the vicinity of $0.05-0.06 \mathrm{~mm}$. In cross-section there is a completely infilled circle, or more rarely a ring, viz. if the cavity has been preserved. The 
needles may be rayed, in which case three or more often four uniform, straight rays emanate from the same point. More irregularly formed spicules are rarer. Under crossed nicols it is possible to see the sphaerulitic, thready structure of the chalcedony, in which the threads are negative.

In those parts of the rock where silicification has proceeded still further, stalactitic masses of chalcedony have been deposited out of the chalcedony of the sponge spicules, thus forming a homogenous flinty rock consisting of sphaerulitic and stalactitic chalcedony and containing scattered remains of the original greensand-stone (Plate 2, Fig. 3 at the bottom). That the silicification has proceeded from the chalcedony of the sponge spicules is clearly recognizable from the fact that the brownish infilling of the spicule cavities is preserved and lies scattered about in the chalcedony mass, without being affected by the silicification as it progressed, whereas the boundary against the remaining greensand masses is quite irregular. Furthermore, not infrequently one finds cavities in the chalcedony in which the stalactitic surface is visible.

3. The greensand limestone is a hardened type but otherwise is built up like the greensand-stone. Here the greensand is cemented by calcite, which is mostly quite clear. Sometimes the calcite forms a coarse mosaic as in the rocks from Copenhagen, but as a rule it is rather fine grained. At Lellinge, too, the calcite may have grown out from the calcareous grains, so that the calcite of the cement is in optical continuity with the adjacent shell fragment. It is especially curious to see the calcite infillings of the holes where the spicules have been (Plate 2, Fig. 4). These cavities are often filled with one or a very few calcite crystals which very distinctly reveal the shape of the cavity. Thus one can see lineal calcite bodies and also circular cross-sections formed of a single calcite crystal. There is scarcely any room for doubt that it is these cross-sections which RøRDAm refers to as "spherical bodies". The sizes he gives fit in very well with the sizes of the sponge spicules.

There is a good deal of truth in Rordan's views on the formation of the flint and chert in the Cretaceous and Paleocene (see p. 62) but strangely enough he has not examined the silicified Paleocene rocks which directly display the circumstances connected with the silicification in the Paleocene. As the flinty rocks in the Paleocene show, the chert has been formed by the crystallization of the opal in the sponge spicules into chalcedony, and, from this, silicification has proceeded through the deposition of new chalcedony formed out of decomposed silica originating from other deposits. The conditions in the various rocks show that the processes of silicification and desilicification have preceded the cementing of the rocks with calcite, and therefore the forming of the chert has probably taken place a short time after the deposition of the rock. 
As regards glauconitizing, pyritizing and cementation the rocks from Lellinge display the same conditions as those from Copenhagen; there too, cementation by calcite was the last process through which the rock passed. One particular deviation is the composition of the lime sand, as at Lellinge a large part of it is composed of fragments of bryozoa, conforming with the fact that the substratum and the disintegrated older sediments there are limestone rich in bryozoa. Another peculiarity of the Lellinge rocks is the occurrence of large numbers of sponge spicules and the associated silicifying processes.

\section{The Unconsolidated Rocks.}

Mechanical analyses and petrographic analyses have been made on three samples, viz.:

Sample No. 1. Greensand from Johnstrup's Boring 3, Sample 10, about $1.6 \mathrm{~m}$ over the Cretaceous.

Sample No. 2. The dark marl.

Sample No. 3. Incoherent, clayey greensand directly overlying the dark marl.

\section{Mechanical Analyses.}

The result of the mechanical analyses will be seen in the Tables $4 \& 5$ and the distribution pyramids (Fig. 14).

Sample 1 presents a type which corresponds exactly to the greensand from Vestre Gasværk; in other words, it is argillaceous fine sand with the grains fairly well sorted. The main grain size lies round about $1 / 16^{1 / 4} \mathrm{~mm}$. The mud content is $27 \%$.

The dark marl and the overlying clayey greensand prove to be almost the same and most nearly correspond to the analyses from the upper part of the Vestre Gasværk series. The mud content is consider-

Table 4.

Mechanical Analyses, Lellinge.

\begin{tabular}{|c|c|c|c|c|c|c|c|}
\hline \multirow[b]{2}{*}{$\begin{array}{c}\text { Sample } \\
\text { No. }\end{array}$} & \multicolumn{7}{|c|}{ Diameter in $\mathrm{mm}$} \\
\hline & 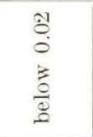 & $\begin{array}{l}\stackrel{8}{8} \\
\stackrel{0}{0} \\
0 \\
0 \\
0\end{array}$ & $\begin{array}{l}9 \\
0 \\
0 \\
0 \\
0 \\
0\end{array}$ & $\begin{array}{c}\stackrel{0}{0} \\
\stackrel{0}{0} \\
0\end{array}$ & $\begin{array}{l}\stackrel{10}{0} \\
0 ! \\
0\end{array}$ & $\stackrel{0}{\stackrel{1}{10}}$ & 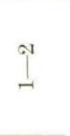 \\
\hline 1 & 28.72 & 7.12 & 17.63 & 41.79 & 4.15 & 0.48 & 0.11 \\
\hline 2 & 73.67 & 10.21 & 14.60 & 0.80 & 0.42 & 0.25 & 0.05 \\
\hline 3 & 65.82 & 13.32 & 16.77 & 3.63 & 0.61 & 0.12 & - \\
\hline
\end{tabular}


able, about $70 \%$, and the sand seems to have its own maximum lying about $1 / 16 \mathrm{~mm}$.

Table 5.

Mechanical Analyses recalculated to Udden's Scale, Lellinge.

\begin{tabular}{|c|c|c|c|c|c|c|c|}
\hline \multirow[b]{2}{*}{$\begin{array}{c}\text { Sample } \\
\text { No. }\end{array}$} & \multicolumn{7}{|c|}{ Diameter in $\mathrm{mm}$} \\
\hline & $\stackrel{N}{I}$ & $\underset{\rightarrow}{-\infty}$ & $\stackrel{+}{-}$ & $\stackrel{\infty}{\stackrel{\infty}{\rightleftharpoons}}$ & $\stackrel{\text { ळ }}{\rightleftharpoons}$ & $\underset{\vec{j}}{\overrightarrow{0}}$ & $\frac{8}{8}$ \\
\hline 1 & 1 & 2 & 25 & 33 & 7 & 5 & 27 \\
\hline 2 & - & - & 1 & 9 & 13 & 5 & 72 \\
\hline 3 & - & 1 & 1 & 13 & 14 & 7 & 64 \\
\hline
\end{tabular}

\section{Mineral Content.}

In all essentials the sand and the mud contain the same constituents as the Paleocene from Vestre Gasværk, and these constituents are the same as those described from the consolidated samples from Lellinge. Therefore it is only necessary to refer here to a few characteristic features which are particularly prominent in the unconsolidated samples.

The calcareous grains. Bryozoan fragments are present in relatively large quantities, particularly in the coarse fractions, foraminifera mostly in the smaller fractions. Secondarily deposited crystalline calcite is sometimes present.

Allochthonous-clastic grains. In addition to quartz, felspar and mica, which form the bulk of the allochthonous minerals, green hornblende, tourmaline and titanite have been observed.

Glauconite occurs as pigment in the lime grains and as independent grains.

Pyrite occurs mostly in the form of small, spherical concretions which, in the dark marl and in the clayey greensand, often coalesce into triangular or disk shaped groups formed in diatoms. In the coarser fractions there is also some pyrite of the shape of sponge spicules.

The mud contains both coccoliths and small isodiametric calcareous grains. Calculations show that the lowest sample (Sample 1) is richer in calcium carbonate in the mud than the others, as the following figures show:

Sample 3. Incoherent clayey greensand $\begin{array}{lc}\text { Calcium carbonate } & \text { Calcium carbonate } \\ \text { in raw sample } & \text { in mud }\end{array}$ over dark marl

2. Dark marl

", 1. Coarse greensand

$57.3 \%$

$45.8 \%$

$57.1 \%$

$75.6 \%$

$49.7 \%$

$68.6 \%$ 
The organisms. Among the organisms which have lived simultaneously with the deposition of the rocks and later have formed a part of them there are especially foraminifera, coccoliths, siliceous sponges and diatoms. The latter two are relatively important; for instance, pseudomorphs of diatoms form a large part of the pyrite in Table 6 , whereas what is included in the column "other constituents" is almost exclusively sponge spicules. A few remains of diatoms are preserved in the form of opal. Some spherical or ellipsoid opal bodies with a pitted surface seem to be radiolaria. A few coproliths of the same type as in the rocks at Vestre Gasværk were found in Sample 1.

\section{Quantitative Proportions.}

The counts. In many respects the quantitative analyses (Table 6) are analogous to those from Vestre Gasværk. The lowest sample, No. 1 has most of its allochthonous-clastic constituents in the second finest fraction $(0.05-0.10)$, fewer in the finer one $(0.02-0.05)$ and a high calcium carbonate content in the mud. The other samples have a greater tendency towards increasing quantities of allochthonous-clastic constituents in the finest fractions and, accordingly, lower calcium carbonate content in the mud. As at Vestre Gasværk there is thus most calcareous mud in the lower samples, most allochthonous clay in the upper samples. Nevertheless, these proportions are not so pronounced as in the marl series at Vestre Gasværk.

The quantitative proportions of the allochthonous-clastic minerals display a similar, but not quite so distinct tendency to that at Vestre Gasværk, viz. highest mica and felspar content in the finest fractions.
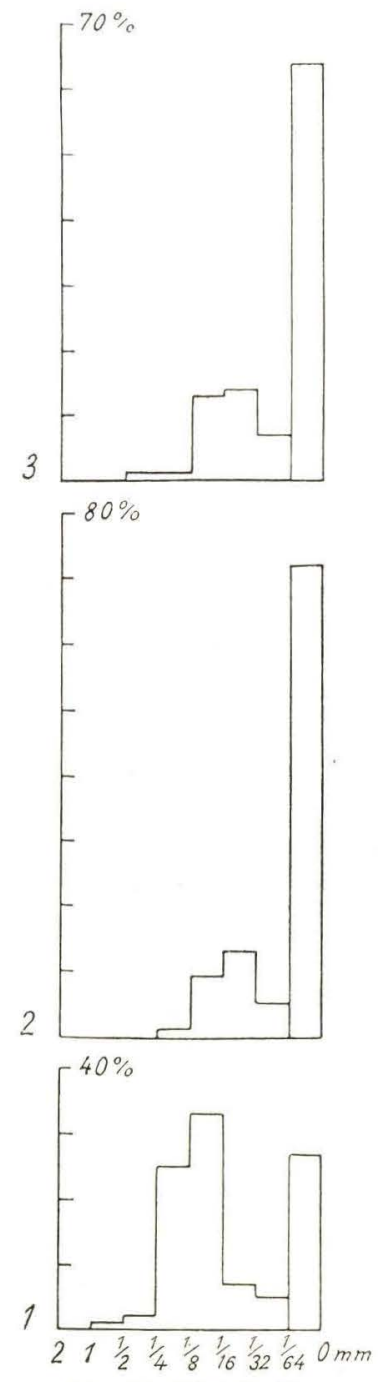

Fig. 14. Distribution pyramids, Lellinge.

The glauconite-pyrite ratio evidences the greensand as glauconitic, the dark marl as more pyritic. In this connection I am able to adduce a glauconite-pyrite count from one of the hard nodules in the marl stratum. For grains with a diameter between 0.02 and $0.05 \mathrm{~mm}$ it gave $92 \%$ glauconite, $8 \%$ pyrite and for grains of more than $0.1 \mathrm{~mm}$ $94 \%$ glauconite, $6 \%$ pyrite. There is a distinct difference from the marl 
in which the nodules lie, which provides us with clear proof that the nodules are foreign bodies in the dark marl. In character they are normal greensand-stone, which in thin section cannot at all be distinguished from the other greensand-stone, and they must have been carried there from the greensand deposits. This means that at Lellinge we have incontestably an intraformational conglomerate, just as at Vestre Gasværk.

The grain distribution. The distribution curves (Fig. 15) show that all three samples contain lime grains grouped about a maximum of sand size, and the glauconite displays the same distribution as the lime sand. In Sample 1 the allochthonous-clastic constituents have a slightly smaller main grain size than the lime sand and the glauconite, whereas in Samples 2 and 3 they distinctly have the same distribution as the lime sand. All three samples must if anything be said to contain the combination lime sand - glauconite sand — quartz sand, as in the lower parts of the Vestre Gasværk series.

Table 6.

Quantitative Analyses, Lellinge.

\begin{tabular}{|c|c|c|c|c|c|c|c|c|c|c|c|c|c|c|c|c|c|}
\hline \multirow[b]{2}{*}{ 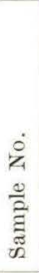 } & \multirow[b]{2}{*}{$\begin{array}{l}\text { Fraction } \\
\text { (diameter } \\
\text { in } \mathrm{mm} \text { ) }\end{array}$} & \multicolumn{5}{|c|}{$\begin{array}{c}1 . \\
\text { Counts of the Composition } \\
\text { of the Fractions }\end{array}$} & \multicolumn{4}{|c|}{$\begin{array}{l}2 . \\
\text { Allochthonous- } \\
\text { Clastic Minerals }\end{array}$} & \multicolumn{2}{|c|}{\begin{tabular}{|c|}
. \\
Glauconite- \\
Pyrite Ratio
\end{tabular}} & \multicolumn{5}{|c|}{$\begin{array}{c}4 . \\
\text { Grain Distribution } \\
(0 / 00)\end{array}$} \\
\hline & & 䓃 & 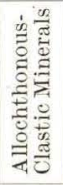 & 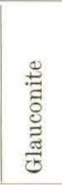 & $\stackrel{\frac{3}{5}}{5}$ & 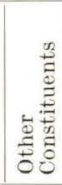 & 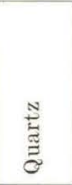 & 节 & 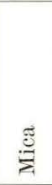 & 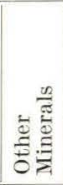 & 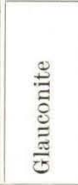 & $\stackrel{8}{5}$ & 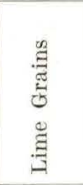 & 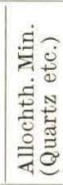 & 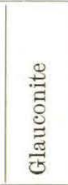 & 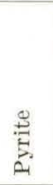 & 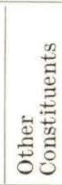 \\
\hline \multirow[t]{5}{*}{1} & $0.02-0.05$ & 85.3 & 0.7 & 7.6 & 3.9 & 2.5 & 93.0 & 3.9 & 3.1 & - & 66.1 & 33.9 & 60.7 & 0.5 & 5.4 & 2.8 & 1.8 \\
\hline & $0.05-0.10$ & 86.3 & 2.5 & 6.1 & 1.0 & 4.1 & 95.2 & 4.1 & 0.7 & - & 86.3 & 13.7 & 152.1 & 4.5 & 10.8 & 1.7 & 7.2 \\
\hline & $0.1-0.2$ & 73.5 & 0.1 & 16.4 & 0.1 & 9.9 & - & - & - & - & 99.0 & 1.0 & 307.2 & 0.5 & 68.4 & 0.7 & 41.1 \\
\hline & $0.2-0.5$ & 81.5 & tr. & 11.4 & 0.2 & 6.9 & - & - & - & - & 98.0 & 2.0 & 33.8 & - & 4.7 & 0.1 & 2.9 \\
\hline & $0.5-0.1$ & $89.5 *$ & 0.6 & 8.2 & - & 1.7 & - & - & - & - & 100 & - & 4.3 & - & 0.4 & - & 0.1 \\
\hline \multirow[t]{5}{*}{2} & $0.02-0.05$ & 77.4 & 5.5 & 6.6 & 8.7 & 1.8 & 96.2 & 2.4 & 1.4 & - & 43.0 & 57.0 & 79.0 & 5.6 & 6.8 & 8.9 & 1.8 \\
\hline & $0.05-0.10$ & 79.5 & 8.3 & 5.7 & 2.8 & 3.7 & 95.7 & 3.5 & 0.8 & - & 67.3 & 32.7 & 116.1 & 12.2 & 8.3 & 4.0 & 5.4 \\
\hline & $0.1-0.2$ & 64.5 & 0.5 & 9.3 & 10.4 & 15.3 & - & - & - & - & 47.4 & 52.6 & 5.2 & - & 0.8 & 0.8 & 1.2 \\
\hline & $0.2-0.5$ & $100 *$ & - & - & - & 一 & 一 & - & - & - & - & - & 4.2 & 一 & - & - & - \\
\hline & $0.5-0.1$ & $100 *$ & - & - & - & - & - & - . & - & - & - & - & 2.5 & - & - & - & - \\
\hline \multirow[t]{5}{*}{3} & $0.02-0.05$ & 80.1 & 9.0 & 4.5 & 0.2 & 6.2 & 92.3 & 6.5 & 0.9 & 0.3 & 94.7 & 5.3 & 106.7 & 11.9 & 6.0 & 0.3 & 8.3 \\
\hline & $0.05-0.10$ & 80.3 & 7.0 & 3.1 & - & 9.6 & 94.2 & 3.5 & 2.3 & 一 & 100 & - & 134.7 & 11.8 & 5.1 & - & 16.1 \\
\hline & $0.1-0.2$ & 72.0 & 6.0 & 4.6 & 0.6 & 16.8 & 94.7 & 3.3 & 0.7 & 1.3 & 88.3 & 11.7 & 24.2 & 2.0 & 1.5 & 0.2 & 5.7 \\
\hline & $0.2-0.5$ & 75.0 & 0.2 & 7.0 & 0.5 & 17.3 & - & - & - & - & 93.3 & 6.7 & 4.6 & - & 0.4 & - & 1.1 \\
\hline & $0.5-0.1$ & $99.8 *$ & 0.2 & - & - & - & - & - & - & - & - & - & 1.2 & - & - & - & - \\
\hline
\end{tabular}




\section{Tune.}

For the purpose of supplementing the description from Lellinge, where the basal deposit of the Paleocene was not directly visible, the following contains a brief summary of conditions at Tune, Forchinammer's old locality, lying about $7 \mathrm{~km} \mathrm{SE}$ of Roskilde, about $15 \mathrm{~km} \mathrm{~N}$ of Køge.

The samples at the Mineralogical Museum from Tune were taken while well digging in 1858 , and they include large compact rock samples which reveal the boundary between Paleocene and Cretaceous.

The greensand limestone overlies a very strongly cemented bryozoan limestone, and the boundary between Danian and Paleocene is very irregular. As at Copenhagen, there are

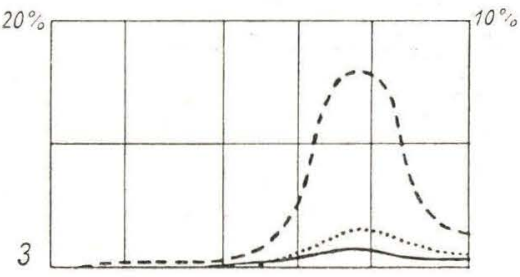
numerous cavities in the limestone, and these have afterwards been filled with greensand. The lowest Paleocene deposit is a hard, greyish-green greensand limestone containing glauconitized pebbles of bryozoan limestone and rolled glauconitized Danian fossils. Among these are many specimens of Tylocidaris spines and Terebratula shells. The fossils are very green. The greensand limestone passes upwards into a rather paler, more greyish and slightly more incoherent greensand-stone.

Under the microscope it appears that the greensand limestone very closely approaches the Lellinge greensand limestone. Large and small bryo-

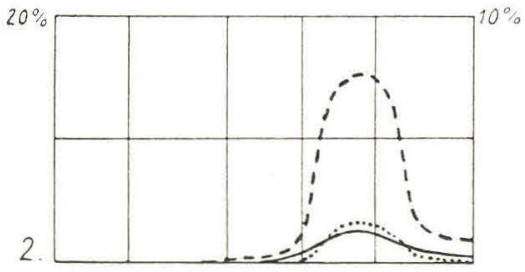

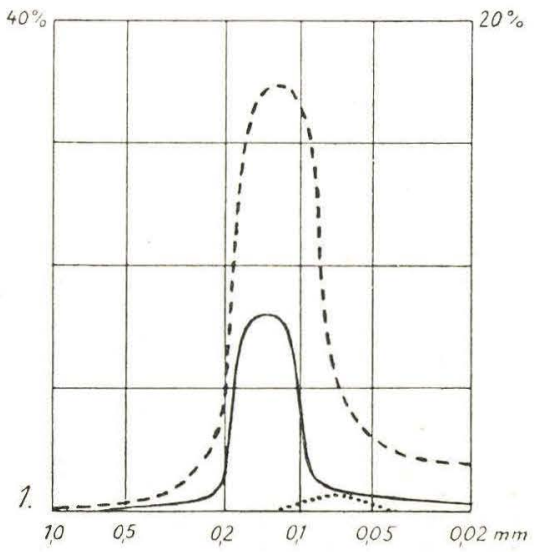

Fig. 15. Distribution curves, Lellinge.

-.- Lime sand; - Glauconite; ..... Allochthonous sand (Quartz etc.). For further explanation see Fig. 11 page 53.

zoan fragments form a great part of the lime grains, especially the large grains, and foraminifera are also plentiful. The lime grains to a great extent are glauconitized in the usual way, this glauconitizing being particularly distinct in the large rolled fossils. Round and lobate, smooth-edged glauconite grains are likewise common. Pyrite occurs in varying quantities in the different samples, partly in the form of in- 
filling in the foraminiferal shells or small grains in the lime grains, partly as concretions or irregular masses lying in these grains. Quartz splinters, which in places reach a size of up to $0.1 \mathrm{~mm}$, are also present but very sparsely. Sponge remains are of frequent occurrence, but are not so common as at Lellinge. As at the latter locality the cavities in the spicules are occasionally full of glauconite. The spicule itself is mostly found as opal; more rarely the sponge spicules have been decomposed, and the cavities left by them may be full of calcite just as at Lellinge. The matrix between the sand particles is a rather fine-grained aggregate which encloses a brownish-grey, apparently argillaceous mass which here and there is greenish in colour and therefore must be partly glauconitic.

The glauconitized pebbles consist of bryozoan limestone, in which the bryozoa lie in an extremely fine-grained calcareous matrix. The rock is entirely permeated with glauconite and finely distributed pyrite, and both these minerals occur in the calcareous grains as well as in the matrix between them.

\section{The Kerteminde Marl in Sealand and Funen.}

As stated earlier (page 17), borings have shown that Paleocene marl has a wide distribution over a great part of West Sealand and Funen. In situ this marl is not known to be exposed anywhere, but it is to be seen in large disturbed blocks, transported by the ice, for instance in Lundsgaard Cliff at Kerteminde (N. V. Ussing 1899, V. Madsen 1902) (Fig. 16), at Hanerup in Northwest Sealand (V. MiLthers 1923, Sigurd Hansen 1930), and at Lejre in Mid-Sealand (Sigurd Hansen 1930). The Paleocene at these localities consists of a homogenous, light, whitegrey marl, which has been called Kerteminde marl after the first known locality where it is exposed. Harder layers, or nodules, impregnated with silica occur very subordinately. As the rocks from the different localities are very closely related, they are here dealt with together.

\section{Earlier Petrographic Investigations.}

Kerteminde marl has previously been examined petrographically by Ussing (in V. Madsen 1902). An elutriation analysis, by O. B. BøGGILD, gave the following values: 


$\begin{array}{lr}\mathrm{CaCO}_{3} & 51.6 \% \\ \text { Grains over } 0.5 \mathrm{~mm} & 2.82 \% \\ 0.01-0.5 \mathrm{~mm} & 6.89 \% \\ \text { Grains under } 0.01 \mathrm{~mm} \quad 38.69 \%\end{array}$

Ussing described the marl and the silicified rocks so thoroughly that I can give supplementary facts only on very few points. In concentrated form Ussing's description of the loose marl is as follows:

"Of organic constituents there are extremely numerous shells of foraminifera, whose chambers sometimes are empty, sometimes full of clay, or they contain pyrite grains or (very rarely) glauconite. As a rule the shells are well preserved, very seldom transformed into chalcedony. Radiolaria occur very rarely; sponge spicules which usually have been pyritized or, more rarely, transformed into chalcedony or glauconite, are of common occurrence, as also are diatoms, disk-shaped and triangular types, transformed into pyrite. In addition to the alreadymentioned pseudomorphs of pyrite on the diatoms there are numerous lumps of pyrite which also seem to be of organic origin. The lumps measure up to $0.3 \mathrm{~mm}$ in diameter and are built up of small spheroids whose diameters in the individual lumps are all the same, but may vary from lump to lump between 0.005 and $0.07 \mathrm{~mm}$. At any rate as regards some of the lumps, the irregular form is connected with the fact that they go to pieces during the preparation of the rock, for in some cases it is seen that part of their periphery has a regular circular form. Some clear, straight lined aragonite stems, occurring only rarely in the rock, also seem to be of organic origin.

The inorganic allochthonous constituents are mostly clay (about $39 \%$ of the rock). Among the coarser grains in the rock the allochthonous particles form only an extremely small part, of which most are quartz and felspar (orthoclase, microcline, some plagioclase). The largest quartz grains are about $0.4 \mathrm{~mm}$ in size, rounded, whereas the smaller ones are angular. Muscovite, garnet, hornblende, zircon and tourmaline have been found in addition to quartz and felspar." 
The hard, silicified parts of Kerteminde marl are described by Ussing as unfinished flint deposits. He examined samples of beach stones from Kerteminde and a silicified sample from a boring at Odense, and describes these rocks in the following manner (translated from Danish):

"Strewn about in a greyish turbid ground-mass (silicified clay) lie innumerable clear sponge spicules of every shape; more scattered, but still in large numbers, are cross-sections of foraminiferal shells; here and there are green glauconite particles (most often of spicule form) and tiny black, pyrite particles. A few indistinct figures in the turbid ground-mass may no doubt be put down as diatoms; in the most silicified sample (Odense), however, these seem to have disappeared. Between crossed nicols one sees that the sponge spicules have been transformed into chalcedony (possibly mixed with fine particles of quartz). The foraminiferal shells are present in the form of calcium carbonate."

Ussing compares Kerteminde marl with the deposits that are being laid down today in the Black Sea at depths of under 500-600 metres, where the water is very rich in hydrogen sulphide. A fine, calcareous ooze is formed there, rich in ferrous sulphide, some of which occurs as tiny spheroids. This type of bottom deposits is rich in diatom shells, and inside them are small spheroids of ferrous sulphide (Androussow 1897). As marine sponges and other organisms occur in Kerteminde marl, the physical conditions under which it was formed have been nothing like so abnormal as those now prevailing in the Black Sea at those depths where, apart from bacteria, living organisms do not occur.

\section{Petrography of Kerteminde Marl.}

Mechanical and petrographic analyses have been made on three samples, two from Kerteminde and one from Hanerup.

\section{Mechanical Analyses.}

The analyses (Table 7) reveal a very low content of grains of over $0.02 \mathrm{~mm}$ (only $1 \frac{1}{2}-6 \%$ ), and decreasing quantities in the coarser fractions; in other words, a typical mud deposit with no accumulation of coarser constituents. Its character as mud reveals the marl as a deposit laid down in still water. 
Table 7 .

Mechanical Analyses, Kerteminde $(1,2)$ and Hanerup (3).

\begin{tabular}{|c|c|c|c|c|c|c|c|}
\hline \multirow[b]{2}{*}{$\begin{array}{c}\text { Sample } \\
\text { No. }\end{array}$} & \multicolumn{7}{|c|}{ Diameter in $\mathrm{mm}$} \\
\hline & 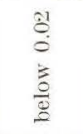 & $\begin{array}{l}\hat{8} \\
\dot{0} \\
\dot{0} \\
\dot{0}\end{array}$ & $\begin{array}{l}0 \\
0 \\
0 \\
0 \\
0 \\
0\end{array}$ & $\frac{\mathfrak{9}}{0}$ & 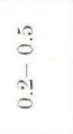 & $\stackrel{0}{1}$ & 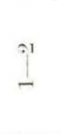 \\
\hline 1 & 98.32 & 1.31 & 0.20 & 0.11 & 0.05 & 0.01 & 一 \\
\hline 2 & 98.53 & 0.88 & 0.18 & 0.14 & 0.13 & 0.11 & 0.03 \\
\hline 3 & 94.13 & 5.43 & 0.40 & 0.04 & - & - & - \\
\hline
\end{tabular}

\section{Mineral Content.}

There is only little to add to Ussing's description.

The calcareous grains in the arenaceous fractions are overwhelmingly, but not exclusively, foraminiferal shells. In addition there are some clear, newly-formed crystals of calcite, especially in the finer fractions. In the marl from Hanerup, and doubtless also - though in smaller quantities - in that from Kerteminde, there are calcareous grains of organic origin (bryozoan remains, foraminiferal shell fragments), which if anything must be taken to be an anchi-autochthonous-clastic constituent, originating from the Cretaceous substratum. Glauconite was seen only as very fine grains, never more than $0.1 \mathrm{~mm}$. Pyrite seems to have been formed in every case as small spheroids, as Ussing describes; this applies both to the diatom fillings and to the sponge spicules, and there can scarcely be any doubt but that the accidentally formed spheroid accumulations for the most part are fragments of diatom fillings (Plate 2, Fig. 2).

The mud in the Kerteminde marl is always of the same character. It contains numerous, clear isodiametric grains and small crystals of calcite. In addition to this inorganic calcareous mud there are always coccoliths; the quantity varies, but at any rate they occur rather frequently.

\section{Quantitative Proportions (Table 8).}

The counts. As Kerteminde marl to such a great extent is built of organic particles (foraminifera, coccoliths, diatoms, sponges, radiolaria) and of chemically precipitated minerals (calcite, pyrite, glauconite) a quantitative count is naturally not of so much interest as in the rocks which mostly contain clastic components. Nevertheless the counts give 
a numerical indication that is at least as eloquent as the literal terms as to frequency.

It is clear that calcium carbonate and pyrite form the main mass of the rock. For the three samples examined the calcium carbonate content is: Kerteminde 1: $65.5 \%$; Kerteminde 2: $53.7 \%$, and Hanerup: $72.9 \%$. Sigurd Hansen (1930) states that the Hanerup marl usually contains $68-70 \%$ calcium carbonate, the similar marl from Lejre district 66-76\%. O. B. BøGGILD's analysis from Kerteminde has $51.6 \%$. The variation in the calcium carbonate content must be due mainly to variations in the chemical precipitation of calcareous mud and in the deposition of coccoliths. The allochthonous-clastic constituents form only about ten per cent. of the finest fraction and still less of the coarser fractions.

The quantitative proportions of the allochthonous-clastic minerals are as usual in the Paleocene, viz. some few per cent. felspar and white mica in the finest fractions.

The glauconite-pyrite ratio reveals the extreme pyritic character of the rock.

The grain distribution is the same for all components, the quantity

Table 8 .

Quantitative Analyses, Kerteminde (1, 2) and Hanerup (3).

\begin{tabular}{|c|c|c|c|c|c|c|c|c|c|c|c|c|c|c|c|c|c|}
\hline \multirow[b]{2}{*}{ 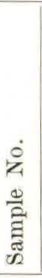 } & \multirow[b]{2}{*}{$\begin{array}{l}\text { Fraction } \\
\text { (diameter } \\
\text { in } \mathrm{mm} \text { ) }\end{array}$} & \multicolumn{5}{|c|}{$\begin{array}{l}1 . \\
\text { Counts of the Composition } \\
\text { of the Fractions }\end{array}$} & \multicolumn{4}{|c|}{$\begin{array}{l}2 . \\
\text { Allochthonous- } \\
\text { Clastic Minerals }\end{array}$} & \multicolumn{2}{|c|}{\begin{tabular}{c|}
3. \\
Glauconite- \\
Pyrite Ratio \\
\end{tabular}} & \multicolumn{5}{|c|}{$\begin{array}{l}4 . \\
\text { Grain } \\
\text { Distribution } \\
(0 / 00)\end{array}$} \\
\hline & & 急 & 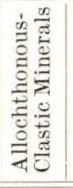 & $\begin{array}{l}\stackrel{\Xi}{\Xi} \\
\stackrel{\Xi}{\Xi} \\
\frac{\pi}{0}\end{array}$ & $\stackrel{\frac{3}{5}}{3}$ & 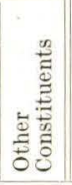 & 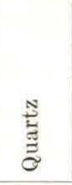 & $\frac{\sqrt{3}}{\frac{3}{3}}$ & 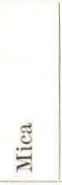 & 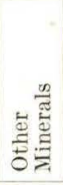 & 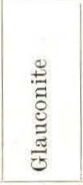 & 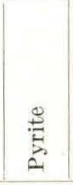 & 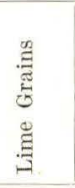 & 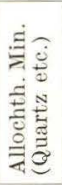 & 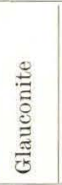 & 总 & 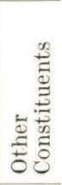 \\
\hline \multirow[t]{5}{*}{1} & $0.02-0.05$ & 50.0 & 8.0 & 1.2 & 27.3 & 13.5 & 94.0 & 3.2 & 2.8 & - & 4.2 & 95.8 & 6.5 & 1.0 & 0.2 & 3.6 & 1.8 \\
\hline & $0.05-0.10$ & $28.1 *$ & 0.2 & 0.1 & 71.1 & 0.5 & - & - & - & - & 0.2 & 99.8 & 0.6 & - & - & 1.4 & \\
\hline & $0.1-0.2$ & $17.5^{*}$ & tr. & - & 82.5 & - & - & - & - & - & - & 100 & 0.2 & - & - & 0.9 & - \\
\hline & $0.2-0.5$ & $22.4 *$ & - & - & 77.6 & - & - & - & - & - & - & 100 & 0.1 & - & - & 0.4 & - \\
\hline & $0.5-1.0$ & ca $45^{*}$ & - & - & ca55 & 一 & - & - & - & - & - & 100 & - & - & - & 0.1 & - \\
\hline \multirow[t]{5}{*}{2} & $0.02-0.05$ & 26.7 & 8.9 & 1.2 & 44.9 & 18.3 & 96.2 & 1.3 & 2.5 & - & 2.6 & 97.4 & 2.3 & 0.8 & 0.1 & 4.0 & 1.6 \\
\hline & $0.05-0.10$ & $27.8 *$ & 1.6 & - & 70.6 & - & - & - & - & - & - & 100 & 0.5 & - & - & 1.3 & - \\
\hline & $0.1-0.2$ & $25.8 *$ & 0.2 & - & 74.0 & - & - & - & - & - & 一 & 100 & 0.4 & 一 & - & 1.0 & - \\
\hline & $0.2-0.5$ & $25.9 *$ & 0.2 & - & 73.9 & - & - & - & $\ldots$ & - & - & 100 & 0.3 & - & - & 1.0 & - \\
\hline & $0.5-1.0$ & $160 *$ & 0.2 & - & 83.6 & 0.2 & - & - & - & - & - & 100 & 0.2 & - & - & 0.9 & - \\
\hline \multirow[t]{3}{*}{3} & $0.02-0.05$ & 69.8 & 12.6 & 1.0 & 9.9 & 6.7 & 94.8 & 3.5 & 1.4 & 0.3 & 9.6 & 90.4 & 37.9 & 6.8 & 0.6 & 5.4 & 3.6 \\
\hline & $0.05-0.10$ & 63.2 & 2.4 & 0.2 & 29.3 & 4.9 & 97.2 & 2.1 & 0.7 & - & 0.8 & 99.2 & 2.5 & 0.1 & - & 1.2 & 0.2 \\
\hline & $0.1-0.2$ & $27.7 *$ & 0.7 & - & 70.3 & 1.3 & - & - & - & - & - & 100 & 0.1 & - & - & 0.3 & - \\
\hline
\end{tabular}


of the particles rising gradually as we come to finer and finer grains. Therefore, having regard to all the components, Kerteminde marl is a mud facies.

\section{The Silicified Rocks.}

The hard silicified parts in the Kerteminde marl are characterized by always being very rich in sponge spicules and by the rock being impregnated with amorphous silica.

Among the silicified samples it is possible to separate two types, corresponding to two of the types from Lellinge. In one type the rock is impregnated with amorphous silica, whereas the spicules are decomposed or consist of opal. In this type there have been exactly the same processes as in the greensand-stone from Lellinge. In the other type the spicules consist of chalcedony as in the chert from Lellinge, but the chalcedony does not seem to have grown further out in the rock, which is impregnated with amorphous silica only.

As regards their mineral content the silicified samples show that the rock originally was of a type that differed from the marl in which it lay. Whereas thin sections of some of the samples reveal a rather fine, turbid silicified mass with numerous sponge spicules and scattered foraminiferal shells, exactly as described by Ussing, there are others which have been much more sandy than the Kerteminde marl. This is true of rocks both from Kerteminde and Hanerup. In those samples there is a rather dense packing of shell fragments and foraminifera lying in the fine brownish turbid matrix, together with the usually very numerous sponge spicules. Quartz grains are scattered about in the form of small angular splinters. Glauconite is rather common, both as grains and as infilling in the spicule cavities. Pyrite, on the other hand, is less prominent. It occurs in the form of fine grains, as infillings in the foraminiferal shells or as small concretions. Most of the arenaceous components have a size of about $0.05-0.10 \mathrm{~mm}$. In the silicified mud it is always possible to discern numerous small calcareous grains and some coccoliths.

It will have been seen from the description of the silicified samples that in the extremely pyritic Kerteminde marl there are subordinary layers of more arenaceous and glauconitic character, so that there is a distinct alternation of facies. It is reasonable to suppose that these layers have been formed in a more oxygenous medium than the marl, as they contain considerable quantities of glauconite, and presumably it was the more oxygenous environment that caused a better growth of the sponges. The many sponge spicules deposited 
in these layers have just had the effect that the most arenaceous and glauconitic layers have undergone a secondary silicifying process.

Similar facies-alternations, but much more pronounced, occur in Djursland (see later p. 106).

\section{The Randers-Djursland District.}

The first to be described in the Randers-Djursland district are the two exposed localities with Paleocene in situ: Hvalløse and Svejstrup, where the boundary between Danian and Paleocene has been observed direct. These two localities provide an impression of the course of the transgression in this part of the country, where the substratum consists of more fine-grained calcareous deposits.

The other localities in Djursland eonsist of greatly dislocated marl deposits. The rocks are light-coloured marl, recalling Kerteminde marl but often containing more glauconite, and harder, silicified rocks which originally have been more sandy and glauconitic. The Paleocene localities all lie within the East Jutland stationary line (Fig. 17) and the series are disturbed, thrust and broken by the advance of the East Jutland ice, for which reason it is as a rule impossible to unravel the original stratigraphical order. In only two localities, which are now to be described: Ommestrup and Holme, is it possible to single out fragments of the Paleocene series.

Finally, a description will be given of the non-calcareous Paleocene rocks exposed in the cliffs south of Rugaard.

\section{Hvalløse.}

The Paleocene observable in situ at Hvalløse, previously described by ØDUM (1926, p. 248), consists of a fairly small marl pit in which it is possible to see the lowest strata of the Paleocene overlying Danian coccolith chalk. When I saw the pit (1932) the sides had slipped a good deal, but by means of excavation I secured a section corresponding to that of ODUM as regards thickness, but my conception of the strata does not quite agree with his.

The substratum to the Paleocene consists of a soft yellowish coccolith chalk which ØDUM attributes to the Younger Danian. The chalk 
is very finely sanded and consists of very small calcareous particles which,

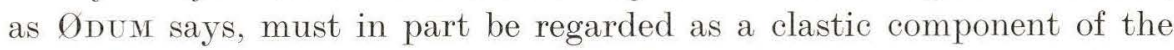
rock. There are quite a number of small foraminifera and an abundance of coccoliths. After treating with dilute acid there is a finely sanded residue containing quite small quartz splinters, a number of small, round particles of glauconite, and a little pyrite.

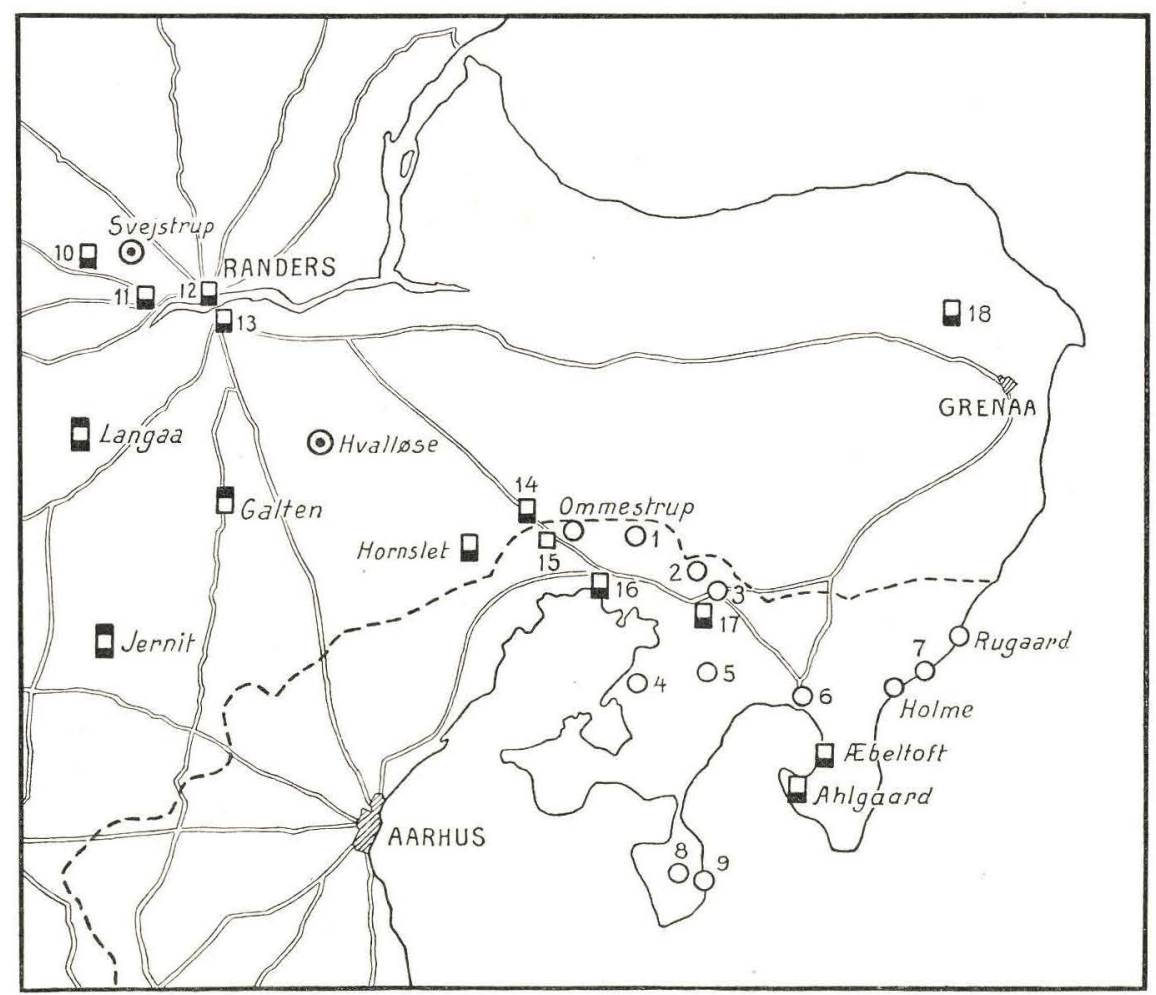

Fig. 17. Map of the localities of Paleocene in Djursland (1:640000). $\odot$ Outcrops of Paleocene in situ (on the substratum). $\bigcirc$ Outcrops of Paleocene, disturbed and

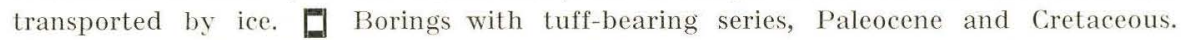
$\square$ Borings with tuff-bearing series and Paleocene. $\square$ Borings with Paleocene and Cretaceous. $\square$ Borings with Paleocene only. -..- East Jutland stationary line (marginal moraine). Dislocated outcrops: 1 Smogen; 2 Korup; 3 Essig; 4 Vrinners; 5 Basballe; 6 Egsmark; 7 Jernhatten; 8 Stødov; 9 Esby. Borings: 10 Bjerregrav [68.17] ${ }^{1}$ ); 11 Over Hornbæk [68.16]; 12 Randers [68.12 \& 14]; 13 Strømmen .[68.8]; 14 Mørke [80.36]; 15 Ommestrup [80.8]; 16 Kaløvig Hotel [80.12]; Møllerup [80.05]; 18 Dahlstrup [71.14].

The boundary against the Paleocene is an abrasion plane with a flint bed which apparently has put a stop to the denudation. The surface of the chalk is full of bored cavities filled with Paleocene greensand.

$\left.{ }^{1}\right)$ Number of the boring in the Boring Archives of Denmark's Geological Survey. 
The Paleocene. Overlying the chalk is a series of about 3 metres of calcareous Paleocene. The lowest metre in the section displays an insensible passage from calcareous gravel at the bottom through fine sand to fat marl at the top. By means of a distinctly marked boundary this lower series is separated from an upper one, consisting of about 2 metres of light-coloured marl.

In the lower metre the bottom $10-15 \mathrm{~cm}$ consist of gravel with numerous glauconitized limestone pebbles, rolled derived Danian fossils and calcareous sand. The gravel grades gradually into fine calcareous sand, which in turn gives place to a loose, fine-sanded marl. This passes smoothly into dark, brownish-grey and rather fat marl, which forms about $25 \mathrm{~cm}$ of the lower series.

The boundary lying 1 metre above the chalk is a distinct sedimentation boundary, horizontal and very sharply delimited. Over the boundary is a marl series about $2 \mathrm{~m}$ thick; its lower part is greyish and contains a quantity of glauconite grains of sand size, whereas the greater part is greyish-white or yellowish, and more fat. At the top is dark-grey marl, which is a weathering horizon of the light marl. That the dark marl is weathered appears from the fact that the pyrite and glauconite have been transformed into limonite, and also from the fact that the boundary is uneven and irregular in its course. On other Paleocene occurrences in Jutland (for instance at Korup, Fig. 17, No. 2) I have seen similar dark-grey clay, occurring immediately under the Quaternary deposits and independently of the stratification of the Paleocene deposits.

The section gave the following samples, which have been elutriated and petrographically examined:

Sample 7: Whitish-yellow marl, $225 \mathrm{~cm}$ above the chalk.

6: Whitish marl, $140 \mathrm{~cm}$ above the chalk.

5: Light-grey marl, a good $100 \mathrm{~cm}$ over the chalk, directly over the dark marl.

4: Upper part of the fat marl, barely $100 \mathrm{~cm}$ over the chalk.

3: Pale, yellowish-green fine sand, $50 \mathrm{~cm}$ above the chalk.

2 : ", " , , , $25 \quad, \quad, \quad, \quad, \quad$,

1: Gravel immediately overlying the chalk.

\section{Mechanical Analyses.}

The results of these analyses appear from the Tables 9 and 10, the section drawing (Fig. 18) and the distribution pyramids (Fig. 19).

The pyramid for the gravel is a double-crested curve, whereby the pebbles are separated from the sandy constituents, as was the case with the gravel in the Vestre Gasværk series. It is characteristic of 
Table 9.

Mechanical Analyses, Hvalløse.

\begin{tabular}{|c|c|c|c|c|c|c|c|c|c|c|c|}
\hline \multirow[b]{2}{*}{$\begin{array}{c}\text { Sample } \\
\text { No. }\end{array}$} & \multicolumn{11}{|c|}{ Diameter in $\mathrm{mm}$} \\
\hline & $\begin{array}{l}\text { 잉 } \\
\text { 离 } \\
\frac{3}{0}\end{array}$ & $\begin{array}{l}\stackrel{3}{0} \\
0 \\
0 \\
0 \\
0 \\
0\end{array}$ & $\begin{array}{l}9 \\
0 \\
0 \\
\stackrel{0}{0}\end{array}$ & $\stackrel{0}{1}$ & $\begin{array}{l}0 \\
0 \\
0 \\
0 \\
0\end{array}$ & $\stackrel{0}{1}$ & $\uparrow_{-1}^{9}$ & $i_{1}$ & $\stackrel{9}{10}$ & $\begin{array}{l}\text { al } \\
1 \\
0\end{array}$ & $\begin{array}{l}0 \\
\text { ลิ } \\
\text { ลे }\end{array}$ \\
\hline 1 & 10.92 & 4.85 & 5.41 & 5.80 & 10.39 & 4.73 & 2.32 & 7.39 & 10,52 & 19.10 & 18.57 \\
\hline 2 & 27.88 & 14.66 & 24.82 & 13.65 & 14.18 & 3.67 & 0.49 & 0.47 & & - & \\
\hline 3 & 36.94 & 16.82 & 41.89 & 3.12 & 0.93 & 0.25 & 0.05 & tr. & - & - & - \\
\hline 4 & 85.75 & 11.23 & 2.02 & 0.69 & 0.23 & 0.05 & 0.03 & - & - & - & - \\
\hline 5 & 65.60 & 18.35 & 8.01 & 4.95 & 2.90 & 0.14 & 0.05 & - & - & 一 & - \\
\hline 6 & 95.83 & 3.59 & 0.24 & 0.16 & 0.12 & 0.05 & 0.01 & - & - & - & -- \\
\hline 7 & 98.70 & 0.69 & 0.32 & 0.14 & 0.10 & 0.04 & 0.01 & & & - & \\
\hline
\end{tabular}

Sample 1 that the curve for the sand particles is flat and spreads over several classes, which means that there has been extremely little sorting. The maximum lies in the grain size $1 / 2^{-1 / 4} \mathrm{~mm}$. The gravel particles also form a rather broad curve, but it is higher than that of the sand. The distance between the maxima of the sand and the gravel is 6 classes, a distance which does not seem to be governed by any law of transport. This again shows that there was little sorting; the mechanical composition is immature. Presumably this is connected with the fact that the gravel, stratigraphically, is a basal deposit formed at the beginning of the transgression.

The sediment over the gravel becomes finer and finer and simultaneously the degree of sorting rises. Immediately over the gravel (Sample 2) the

Table 10 .

Mechanical Analyses recalculated to Udden's Scale, Hvalløse.

\begin{tabular}{|c|c|c|c|c|c|c|c|c|c|c|c|c|c|}
\hline \multirow[b]{2}{*}{$\begin{array}{c}\text { Sample } \\
\text { No. }\end{array}$} & \multicolumn{13}{|c|}{ Diameter in mm } \\
\hline & $\begin{array}{l}\hat{\sigma} \\
\hat{0}\end{array}$ & 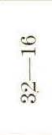 & $\begin{array}{l}\infty \\
\bullet\end{array}$ & $\vec{j}$ & $\begin{array}{l}* \\
+\end{array}$ & $T_{i}$ & $\stackrel{9}{I}$ & $\begin{array}{l}\stackrel{+}{-} \\
\stackrel{a}{-}\end{array}$ & $\stackrel{\infty}{-}$ & $\frac{\stackrel{\infty}{7}}{-\infty}$ & $\frac{9}{7}$ & 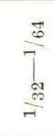 & 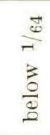 \\
\hline 1 & 5 & 21 & 16 & 9 & 5 & 2 & 5 & 8 & 6 & 6 & 4 & 3 & 10 \\
\hline 2 & & & - & & & 1 & 4 & 10 & 13 & 20 & 19 & 7 & 26 \\
\hline 3 & -- & 一 & - & - & 一 & - & 一 & 1 & 1 & 25 & 31 & 7 & 35 \\
\hline 4 & - & 一 & - & - & - & - & - & - & 1 & 1 & 5 & 11 & 82 \\
\hline 5 & & - & - & - & - & & 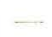 & 2 & 4 & 7 & 11 & 18 & 58 \\
\hline 6 & - & 一 & - & 一 & - & 一 & - & 一 & - & - & 2 & 4 & 94 \\
\hline 7 & - & - & - & - & & - & & - & & $\cdots$ & 1 & 1 & 98 \\
\hline
\end{tabular}


degree of sorting is still low, but the maximum lies within $1 / 8^{-1 / 16} \mathrm{~mm}$, i. e. in a smaller grain size than in the gravel. Half a metre above the gravel the sediment (Sample 3) is typically well-sorted fine sand, whereas higher up the section there is fine clay with few sandy constituents (Sample 4).

The sharp sedimentation boundary becomes visible in the mechanical analyses in the form of a jump in the mechanical composition. Both under and over the boundary there is a mud rock of the usual type, i. e. the quan-

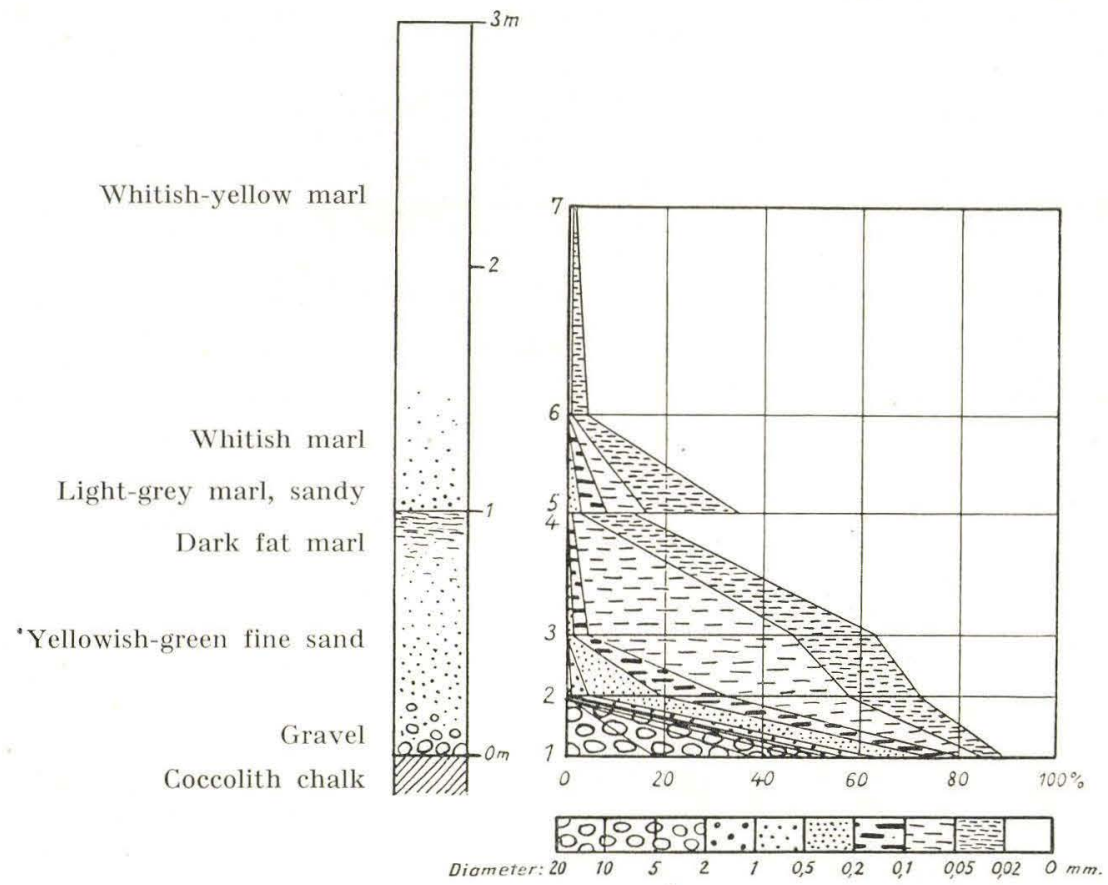

Fig. 18. Mechanical composition of the rocks in the section at Hvalløse.

tity of arenaceous components decreases gradually as the grain size increases, but the rock above the sedimentation boundary (Sample 5) contains more arenaceous components than that below it. The slightly sandy rock over the boundary passes quickly into marl which is almost free of sand.

\section{Mineral Content.}

The gravel components consist most of all of glauconitized limestone pebbles which are very hard, but so fragile that they break easily. The pebbles are greenish and brownish in colour and contain many boreholes. In addition to these pebbles there are numerous rolled and glauconitized Cretaceous fossils and casts.

The grain size above $10 \mathrm{~mm}$ consists exclusively of limestone pebbles of the type described. In the finer gravel fractions there is also an in- 
creasing number of glauconitized shells, and the fractions of less than $2 \mathrm{~mm}$ contain only shells. Among the shells the coral Ceratotrochus milthersi is the commonest form; but fragments of asteroids, stem-ossicles of Bourgueticrinus, remains of echinoids, Terebratula etc. are also found. Apart from Ceratotrochus milthersi, which has never been found in primary place of deposition, the fossils agree with those found in the coccolith chalk.

Arenaceous components. The calcareous grains in the finer sand fractions consist of more or less angular fragments, in some cases glauconitized. As a rule the structure shows that the particles are of organic origin, and fragments of foraminifera are particularly frequent. In the coarser sand fractions of the lower samples the lime sand consists mostly of rolled and glauconitized shell fragments: echinoid spines, coral fragments, bryozoan fragments and foraminifera; in the upper samples the coarse lime particles are almost exclusively fresh Paleocene foraminifera. Secondarily deposited small crystals of clear calcite occur especially on the lime grains in the fine sand fractions, where there is also a small quantity of clear, newly-formed calcite in the form of rhombohedrons.

The allochthonous-clastic grains are the same as in the already described Paleocene rocks, viz. especially quartz, felspar (orthoclase, microcline, plagioclase) and white mica. Of the accessorial minerals green hornblende is the commonest, tourmaline and zircon rather rare.

Glauconite occurs as pigment in the lime grains and also as glauconite grains of the usual lobate or rounded type, as well as in the form of infilling of foraminiferal chambers.

In the residue remaining after treating the fractions with dilute hydrochloric acid, one sees that some of the glauconite distinctly has a struc-

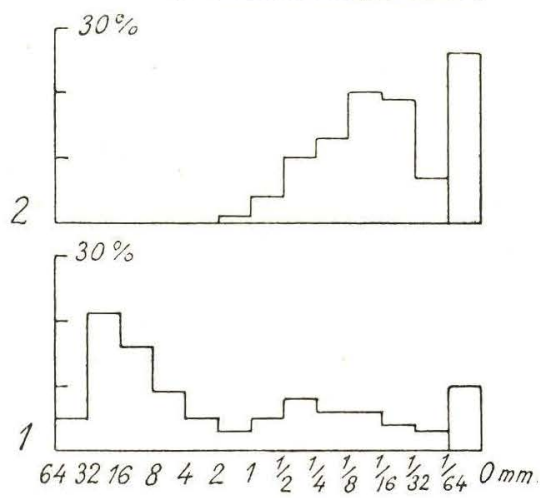

Fig. 19. Distribution pyramids, Hvalløse. 
ture differing from the usual glauconite aggregate. There is a thready or prismatic structure, in which the particles lie in regular orientation, either in such a manner that the whole mass forms an optical unit, or so that there are parts which become extinet simultaneously, but in a position that differs from the adjacent areas. For example, it is not uncommon that there are several planes, each consisting of almost parallel threads, but the direction and optical orientation of the threads vary in the different planes. Where the thready structure is distinct, there is parallel extinction. Some of the grains found at right angles to the direction of the threads display no interference colour, but in one case I have observed an uniaxial negative interference figure.

That these glauconite masses have been formed by the glauconite having replaced organic carbonate of lime appears clearly both from their shape and from their structure, which strongly recalls that of the shells of lamellibranchs. In them we have a genuine pseudomorph of glauconite on the calcareous shell. Only a small part of the glauconite has the aforesaid orientation of the small crystals, the greater part of it being formed of an extremely fine aggregate with a confusion of small particles, like the pigmentary glauconite from Copenhagen and the glauconite grains.

The peculiar mode of occurrence of the glauconite shows that in certain cases it may be made in crystalline form, whereas the normal condition is that the glauconite is deposited as a gel, which afterwards crystallises and forms a fine aggregate (CAspari 1910; Hummel 1922; Berz 1921; HADDING 1932).

Pyrite occurs in the form of small concretions and as fine particles in the lime grains, subordinately as concretions of triangular or disk shape as in the Kerteminde marl. Gypsum was found very subordinately as crystals and crystal fragments in the upper samples which, by their brown-coloured pyrite and glauconite, show that there has been a weathering process. Chalcedony and opal occur very subordinately in the form of sponge spicules and foraminifera.

The mud. Like all the already described Paleocene rocks, the mud contains isodiametric, clear calcareous grains which probably to a great extent are anchi-autochthonous, but partly chemically precipitated, as also are a quantity of clear calcite rhombohedrons. Coccoliths occur rather abundantly.

\section{Quantitative Proportions (Table 11).}

The counts. The first column of the table shows that the greater part of the arenaceous components of the rocks consist of lime grains and glauconite grains. Pyrite and siliceous organisms (most of those counted under "other constituents") are only of very slight importance. The con- 
Table 11.

Quantitative Analyses, Hvalløse.

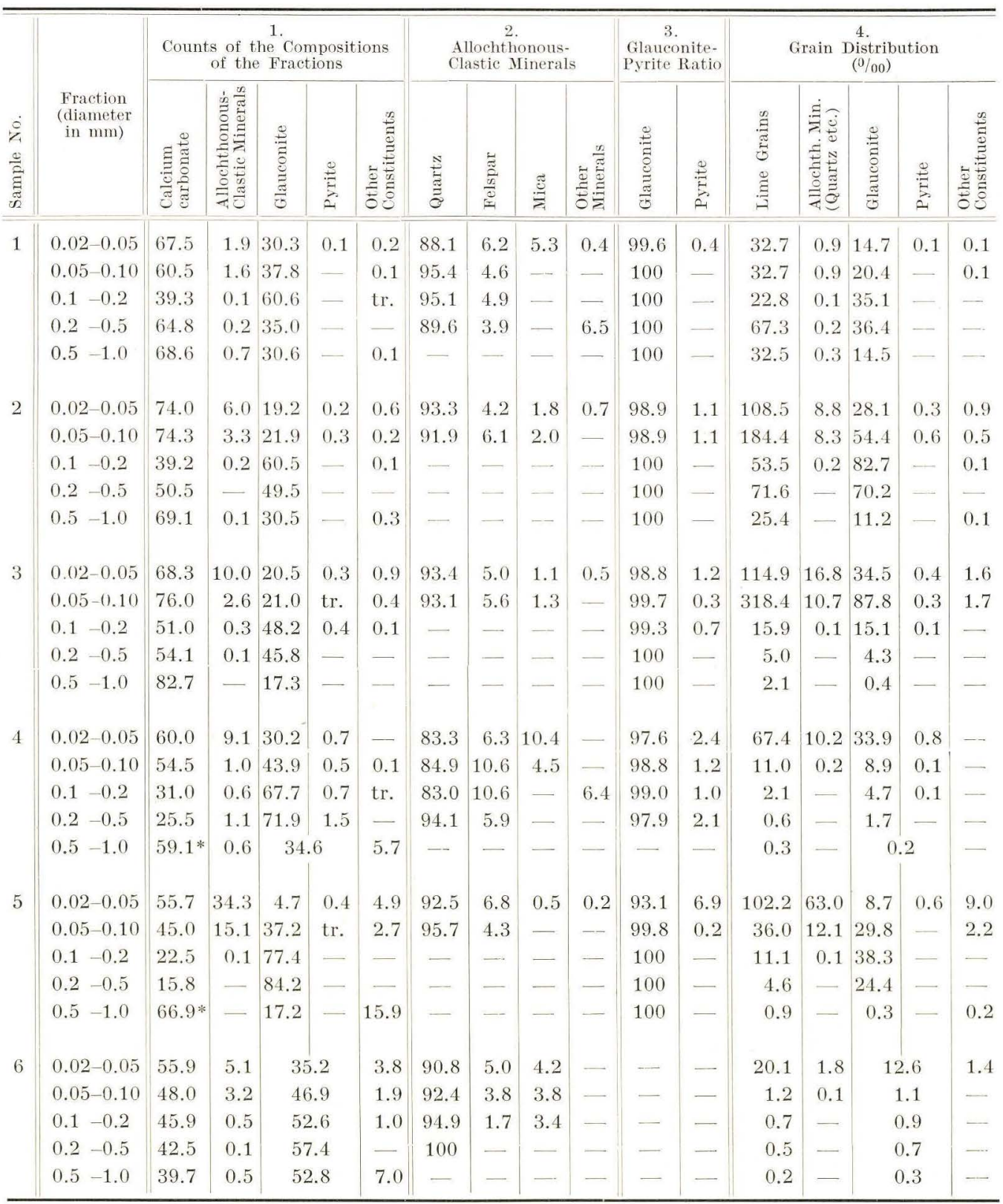

tent of allochthonous-clastic components varies somewhat but is of considerable interest to our understanding of the building up of the rocks. Calcium carbonate content. The calcium carbonate content of the 
mud has been calculated by means of the calcium carbonate content of the raw samples and the various fractions. The result appears from the following table:

\begin{tabular}{l|c|c|c|c|c|c|c}
\hline \multicolumn{1}{c|}{ Sample No. } & 1 & 2 & 3 & 4 & 5 & 6 & 7 \\
\hline \hline Raw sample & 56.3 & 56.5 & 59.5 & 29.3 & 36.3 & 57.3 & 64.3 \\
Mud & 43.4 & 41.9 & 38.0 & 24.7 & 31.9 & 57.5 & \\
\hline
\end{tabular}

In the lower metre of the section, which forms a sedimentation unit (Samples 1-4), it is seen that the quantity of calcium carbonate in the raw samples is greater in the middle and smaller in the lower and upper strata, whereas the mud declines gradually in calcium carbonate content from the bottom to the top. This is explained by a consideration of the quantity of arenaceous components and allochthonous clay. In the lower strata sand plays a great part, and the principal constituents of the sand are lime grains and glauconite. The large quantity of glauconite has the effect that the calcium carbonate percentage in the rock is not particularly high. In the middle of the lower series the quantity of glauconite is not so great, whereas mud and the calcareous fine-sand fractions are in the majority, so that the calcium carbonate content of the whole rock rises. Uppermost in the section it is the mud that predominates, and, as the analyses show, the mud contains less and less calcium carbonate upwards, so that the calcium carbonate content of the rock again falls.

The sharp sedimentation boundary is also apparent in the calcium carbonate content, for both the rock and the mud are richer in calcium carbonate above the boundary. As a large part of the calcium carbonate in Sample 5 is a clastic component, there must have been a fresh supply of calcareous sand and mud to the place of sedimentation, and thus new quantities of older calcareous rocks in the vicinity must have been broken down — which provides evidence that the disintegrating forces have worked with varying intensities at different times. Whereas fluctuations in the erosion at Vestre Gasværk were reflected in the occurrence of beds of shelly gravel, here they appear in the form of a higher calcium carbonate content and a somewhat coarser character in the marl. This circumstance is connected with the fact that at Copenhagen the Paleocene has been deposited at the expense of lime-sand, but at Hvalløse at the expense of a fine-grained coccolith chalk.

Upwards in the section the calcium carbonate content in rocks and mud rises. The natural explanation would seem to be that the large quantity of glauconite in the most sandy sample (No. 5) had some bearing on this, but as the mud also displays the same variation, that explanation is not sufficient. However, it is obvious that with regard to the arenaceous components the allochthonous admixture is greatest in the lowest sample 
of the upper series (see Table 11, 1st column, Samples 5 and 6), and on account of the calcium carbonate content I suppose that conditions are the same in the mud. In addition, the number of coccoliths in the mud increases upwards in the section. All the circumstances thus go to show that the quantity of transported components (allochthonous fine sand and clay, and glauconite) decreases upwards in the section, whereby the rock more and more becomes a purely chemical and organic calcareous sediment.

The distribution of the allochthonous-clastic minerals in the various fractions reveals characteristic features similar to those in the Vestre Gasværk series. The quantity of allochthonous components is greatest in the finest fractions, smaller and smaller in the coarser fractions. Nevertheless, in Samples 1 and 2 there is a secondary maximum in the grain size 0.5-1 mm, and the same in Sample 4 in the fraction $0.2-0.5 \mathrm{~mm}$. As at Vestre Gasværk, this intermixture of coarse sand may possibly be regarded as an anchi-autochthonous component, originating in denuded Cretaceous rocks. In the upper part of the section it has disappeared.

In the lower metre of the section there is a steady rise in the quantity of allochthonous clay and its associated fine sand, as was the case in the Vestre Gasværk series. The upper series commences with an admixture of allochthonous clay and fine sand, but this soon disappears.

In all the samples the gla uconite is grouped about a special maximum of sand grain size, a circumstance which shall be discussed in the following when dealing with the grain distribution.

The quantitative proportions of the allochthonous-clastic minerals resemble in every way those in the other Paleocene rocks. Quartz is the commonest mineral in all the fractions. Felspar (orthoclase, microcline and plagioclase) forms a smaller part of most fractions, especially the finer ones, and white mica occurs exclusively in the finest grain sizes.

The glauconite-pyrite ratio shows that all the samples are glauconitic. Sample 6 being very weathered, no count of the proportion of glauconite to pyrite could be made, but the shape of the rust-coloured grains might indicate that this sample contains pyrite in greater quantity than the others.

The grain distribution. The table of grain distribution and the distribution curves of the more or less transported constituents contain types not hitherto described (Fig. 20).

Samples 1 and 2 are of the same type of sediment and differ from each other merely in the fact that Sample 1 contains pebbles, whereas Sample 2 does not. The two samples have already (see mechanical analyses) been characterized by their slight degree of sorting. The distribution curves now show that it is mainly the lime sand that is unsorted, the lime sand curve having a very irregular course. The glauconite grains, on the 

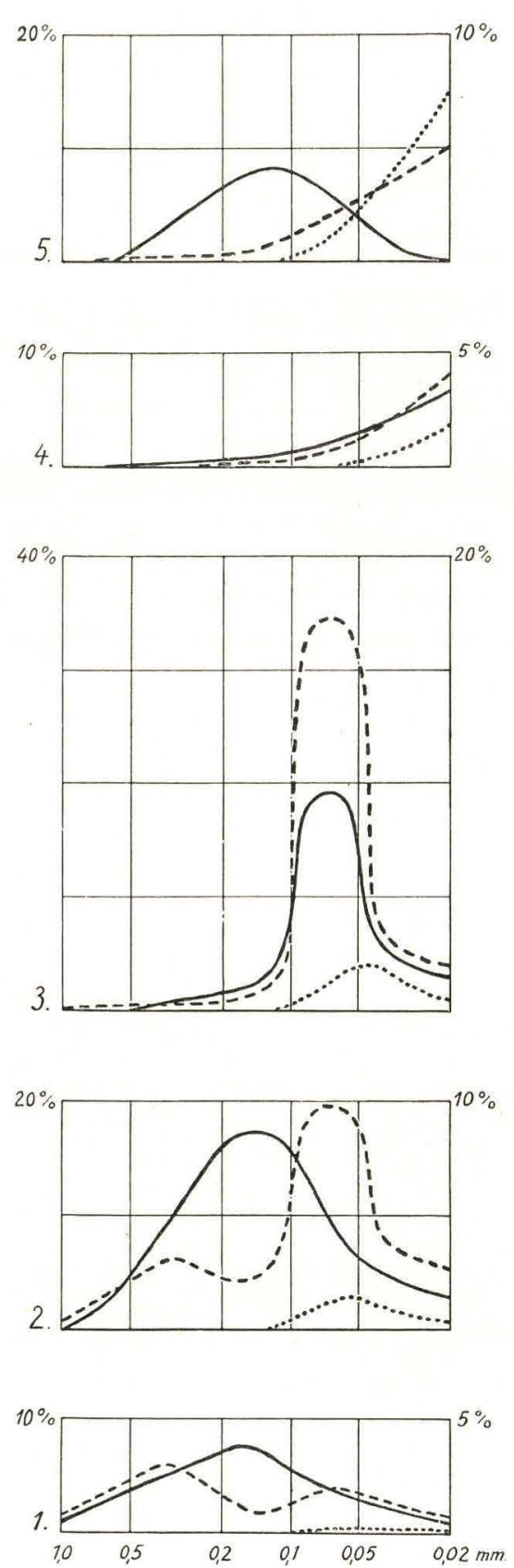

Fig. 20. Distribution curves, Hvalløse. -..-- Lime sand; — Glauconite; Allochthonous sand (Quartz etc.). For further explanation see Fig. 11 page 53. other hand, display a distinct grouping round a maximum in the fraction 0.1-0.2 mm. In Sample 1 the allochthonous grains are of no importance, whereas in Sample 2 they form a maximum lying near to the main maximum of the lime sand but differing from that of the glauconite.

Higher up in the series, where the degree of sorting is higher (Sample 3), we find the type that contains lime sand, glauconite sand and quartz sand sorted with the same maximum, and at the top (Sample 4) a type in which all the components are grouped with increasing quantities in the finer fractions, that is to say, it is a type which, having regard to all its components, is a mud type.

Over the pronounced sedimentation boundary is again a type (Sample 5) which, as far as concerns the glauconite distribution, is comparable with Samples 1 and 2, the glauconite having its own maximum independently of the other components. In this sample the lime sand and the allochthonous components occur with increasing numbers in the finer fractions, so that it contains the combination calcareous mud - allochthonous clay, but the glauconite grains group themselves about a maximum in the fraction $0.1-0.2 \mathrm{~mm}$, exactly as in Samples 1 and 2. It is obvious that here, too, the special glauconite content is connected with the fact that we are at the bottom of a sedimentation series, for this type passes upwards into a normal mud-facies (Samples 6 and 7 ).

In a comprehensive work on glau- 
conite, BERz advanced the hypothesis that glauconite may be formed by flocculation in the water and that the glauconite grains are formed by conglomeration of the glauconite floccules in agitated water (BERz 1921), and various investigators have pointed out that glauconite grains always are of the same size as the other sand grains in the glauconitic sediment (CAyeux 1897; Berz 1921). The distribution curves for Paleocene rocks show, however, that this is not always the case, but that glauconite grains have their own size in rocks which are only poorly sorted. The distribution in the rock types containing glauconite in a special maximum can scarcely be explained in any other way than by assuming that the glauconite as an independent component has settled on a sea floor with little agitated water from more agitated water levels where the conglomeration of the glauconite floccules into glauconite grains has taken place. Accordingly, I would explain the distribution of the glauconite grains in the sediments in the following manner:

In the unsorted or poorly sorted sediments, the glauconite grains group themselves about a main grain size that is governed by the agitation of the water strata in which the glauconite grains are formed, not by the agitation of the water on the sea floor where the glauconite is deposited. For this reason we find in such sediments a special grouping of the glauconite grains, whereas the grain size of the other components is independent of that of the glauconite.

In the sorted sediments, the glauconite grains are sorted together with the other components. For this reason we find in the sorted rocks the same distribution proportions for glauconite as for the other components.

\section{The Limestone Pebbles.}

The limestone pebbles from the gravel are mostly very rounded, but at the same time attacked by boring, the bore-holes extending far into the pebble and often widening out inside it.

Under the microscope the pebbles reveal themselves as fine-grained limestone with numerous foraminifera and other organic fragments. Glauconite has penetrated everywhere, both into the lime particles and between them, and it colours all parts of the thin sections with a brownishgreen or purer green. In places the colour passes into quite a red-brown tint; but, as there is a smooth transition between the variously-coloured areas, there is scarcely any doubt but that all the coloured substance is glauconite or weathering products of that mineral. To a great extent the glauconite has replaced the calcite, as can be visualised by an analysis of the calcium carbonate content made on a sample consisting of several 
pebbles. The calcium carbonate content was only $39 \%$. ØDum has an analysis of a pebble which had only $32 \%$ calcium carbonate. - It is almost impossible to decide if the pebbles have been hardened before being glauconitized, but as there are no distinct traces of secondary calcite cement in the rock, this may have been the case only very slightly. On the other hand, of course, pebbles cannot be made of a quite unhardened calcareous rock.

Whereas now the substratum at Hvalløse consists of coccolith chalk, the pebbles must if anything be described as foraminiferal limestone. This must have come from entirely disintegrated deposits, and in fact this is borne out by the occurrence of Ceratotrochus mitthersi, which is not found in the adjacent Danian localities, though apparently it is derived from the Danian. The nature of the pebbles and the occurrence of the said coral in large numbers indicate an extremely active disintegration of Danian deposits during the transgression of the Paleocene sea.

\section{Svejstrup.}

The Paleocene exposed in situ at Svejstrup consists of a rather small pit in which, as at Hvalløse, the lowest Paleocene stratum has been found overlying Danian coccolith chalk. The section has been described earlier by ØDUM (1926 p. 46 and 249), who says (in summarized form):

"The substratum was visible in the deepest part of a corner of the pit. It consists of a greyish-white coccolith chalk with a slightly gritty feel. The upper limit of the chalk is a distinct surface of denudation, full of boreholes, as at Hvalløse. On the chalk rests a fat grey marl, the bottom stratum of which contains glauconitized pebbles of limestone. Upwards the grey marl passes into lighter Tertiary marls, partly with brown weathering products."

I have not seen the substratum myself, but the whole of the Paleocene series from and including the upper part of the marl with pebbles. I also found excavated lumps of the lowest part of the marl with pebbles, and coccolith chalk.

The lower part of the marl with pebbles consists of coarse, yellowishgreen, mottled, arenaceous glauconitic marl with scattered pebbles of limestone and squeezed-out, lens-shaped masses of incoherent yellowish lime-sand. These lime-sand lenses lie rather close together in places and contribute towards giving the rock its mottled appearance.

The lowest of the deposits observed in situ by the author consists of greenish to greyish mottled marl with a few pebbles and a small number of lime-sand lenses. As ØDUm states that pebbles are to be found up to 
$25 \mathrm{~cm}$ above the bottom of the Paleocene, the more sandy part of the marl with pebbles must be directly under this deposit. Upwards the rock becomes less and less sandy and more and more finely mottled, with lighter and darker grey portions. About $2 \mathrm{~m}$ from the bottom the rock passes into a fat marl devoid of exterior structure and stratification. There are about $5 \mathrm{~m}$ of fat marl, the lower part being light grey, the upper part yellowish on account of weathering. The weathering boundary is irregular, the upper three of four metres being yellow. The section thus is as follows:

3-4 $\mathrm{m}$ weathered, yellowish-white fat marl.

$2.5-1.5 \mathrm{~m}$ grey fat marl.

$1.5 \mathrm{~m}$ mottled, greyish to greenish marl, more sandy below.

$0.25 \mathrm{~m}$ sandy, yellowy-green marl, with glauconitized limestone pebbles.

Coccolith chalk (Danian).

The samples collected are:

No. 5. $1.0 \mathrm{~m}$ below upper edge. Fat, light yellow marl, weathered.

, 4. $4.75 \mathrm{~m} \mathrm{\quad , \quad} \mathrm{,} \mathrm{\quad ,} \mathrm{Fat} \mathrm{grey} \mathrm{marl.}$

, $3.6 .20 \mathrm{~m} \quad$, , , , Mottled, slightly sandy, grey marl.

, 2. $7.0 \mathrm{~m} \mathrm{,.,} \mathrm{,,} \mathrm{,"} \mathrm{Mottled,} \mathrm{sandy,} \mathrm{yellowy-green} \mathrm{marl}$ with a few pebbles.

, 1. Marl with pebbles.

A thin section of the matrix of the marl with pebbles contains a number of large glauconite grains which are rounded and lobate, lying in a groundmass of fine calcareous and argillaceous matrix containing closely packed shell fragments and scattered quartz particles as well as pyrite. In addition to free grains, the glauconite occurs as pigment in the shell fragments. The coarse sandy particles — especially the glauconite grains — display a tendency to stratified accumulation, and the stratification is made still more pronounced by some secondarily deposited masses of pyrite, which surround and to some extent replace the glauconite (Plate 2 Fig. 5). The size of the glauconite grains lies mostly between 0.1 and $0.3 \mathrm{~mm}$, whereas the maximum size of the quartz grains is round about $0.05 \mathrm{~mm}$. It will be seen that there is a considerable difference in size between the glauconite and the quartz grains, as is also revealed by the grain distribution curves; this accords with some of the samples from Hvalløse.

The pebbles from Svejstrup are of exactly the same appearance as those from Hvalløse, and the microscopic examination shows that they are also the same in structure. 


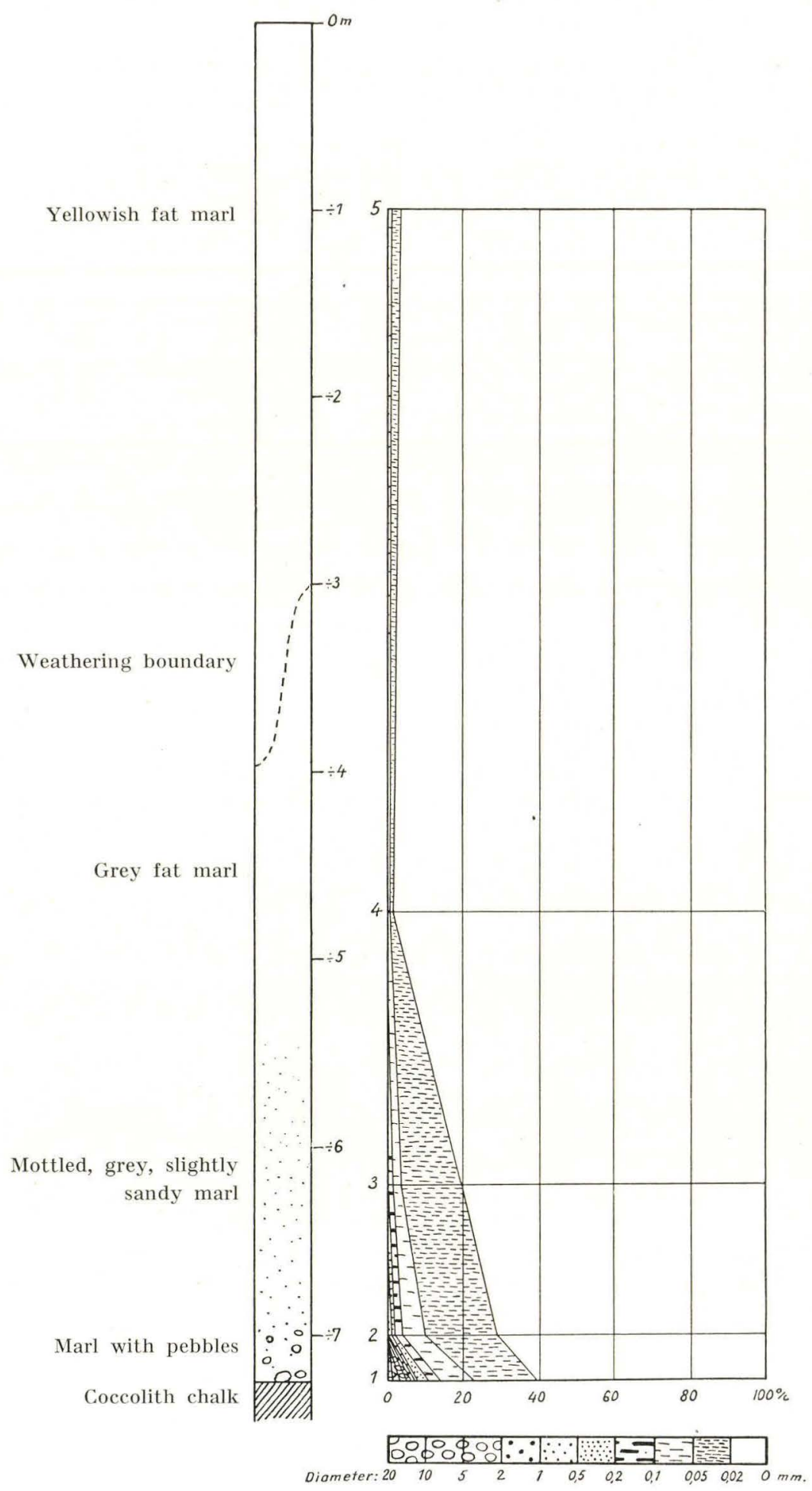

Fig. 21. Mechanical composition of the rocks in the section at Svejstrup. 
Mechanical Analyses. (See the Tables 12 and 13, section drawing (Fig. 21) and distribution pyramids (Fig. 22)).

The mechanical analyses show that the main constituent of all the samples is mud, and in addition there is fine sand which groups with increasing quantities in the finest fractions. The distribution pyramid for the marl with pebbles displays the same characteristic features as the gravel at Hvalløse, but pebbles form only a very small part of the rock. The curve is flat, so that the components are very poorly sorted. Upwards in the section the sand content falls gradually, and the upper samples contain grains almost exclusively less than $0.02 \mathrm{~mm}$.

\section{Mineral Content.}

The mineral content is the same as in the Hvalløse series, as also is the character of the grains. Pyrite, which plays a great part in all the rocks except the very lowest, occurs almost exclusively in the same manner as in the Kerteminde marl, i. e. in the form of diatom infillings, irregular concretions or casts of sponge spicules, all formed of tiny spheroids.

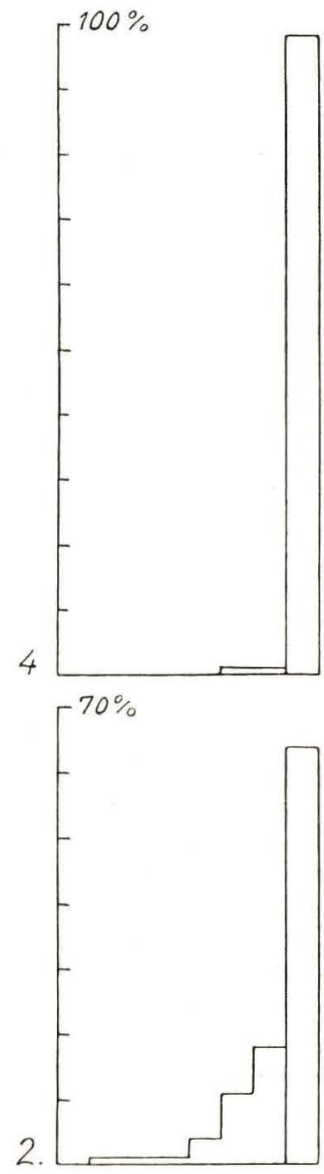

Quantitative Proportions (Table 14).

The counts. On several points the mineral grain counts show conformity with the rocks at Hvalløse. This applies to the distribution of the lime grains, the glauconite and the allochthonous grains in the various sizes, though it should be observed that no anchi-autochthonous group is observable among the latter. The distribution of the proportion between the al-

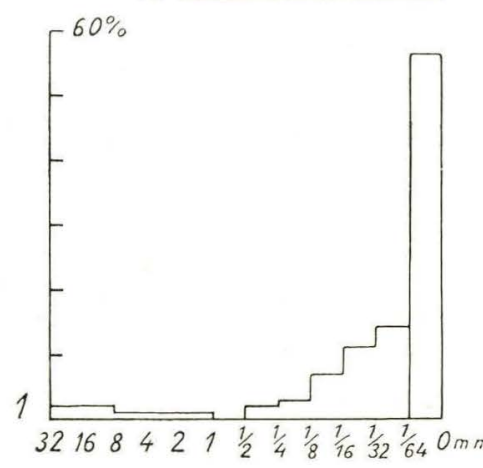

Fig. 22. Distribution pyramids, Svejstrup. lochthonous-clastic minerals also seems to be like that at Hvalløse. On the other hand, the variation in the calcium carbonate content of the rocks and the proportion of glauconite to pyrite are matters requiring a closer examination. 
Calcium Carbonate Percentages.

\begin{tabular}{l|c|c|c|c|c}
\hline \multicolumn{1}{c|}{ Sample No. } & 1 & 2 & 3 & 4 & 5 \\
\hline \hline Raw sample & 59.7 & 45.5 & 48.2 & 69.0 & 54.0 \\
Mud & 61.6 & 41.6 & 44.4 & 69.2 & 54.0 \\
\hline
\end{tabular}

From this table, which indicates the calcium carbonate content in the rocks and the mud, we see that the raw samples and the mud have almost the same percentage, even in the most sandy samples, which means that the differences in the calcium carbonate content in the rocks are principally due to differences in the mud. However, as the mud cannot be subjected to a direct mineralogical analysis, we must attempt to decide by considering the finest sand particles which minerals cause the differences in the calcium carbonate content in the mud. A comparison between the calcium carbonate content and the content of various sandy components (Table 14) shows that there is a regular relation between the calcium carbonate quantity and the quantity of fine allochthonous sand, as the calcareous rocks contain few fine allochthonous sandy components, whereas those poor in calcium carbonate contain many. On the other hand the other fine sandy components do not vary regularly with the calcium carbonate content. If from this we draw conclusions as to the still finer components (viz. the mud), the result is that the calcium carbonate in the mud stands in inverse ratio to the content of allochthonous mud, i. e. the two essential components in the mud are the calcareous mud and the terrigenous clay, whereas the other components are of no great significance to the variations in the mud.

Apart from the marl with pebbles, which, on account of the calcareous smears it contains, is relatively rich in calcium carbonate, we find an increasing calcium carbonate content from the bottom up to the middle

Table 12.

Mechanical Analyses, Svejstrup.

\begin{tabular}{|c|c|c|c|c|c|c|c|c|c|c|c|}
\hline \multirow[b]{2}{*}{$\begin{array}{c}\text { Sample } \\
\text { No. }\end{array}$} & \multicolumn{11}{|c|}{ Diameter in $\mathrm{mm}$} \\
\hline & 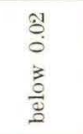 & $\begin{array}{l}18 \\
\stackrel{8}{0} \\
1 \\
8 \\
0 \\
0\end{array}$ & $\begin{array}{l}0 \\
0 \\
0 \\
0 \\
0\end{array}$ & $\frac{\stackrel{0}{0}}{0}$ & $\begin{array}{l}13 \\
0 \\
01 \\
0\end{array}$ & 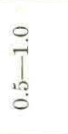 & 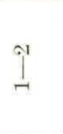 & $i_{i 1}^{1}$ & $\prod_{10}^{9}$ & $\begin{array}{l}\text { ब1 } \\
\stackrel{9}{0}\end{array}$ & 高 \\
\hline 1 & 61.04 & 16.27 & 9.23 & 3.04 & 2.94 & 0.78 & 0.68 & 0.87 & 2.11 & 1.88 & 1.16 \\
\hline 2 & 71.03 & 19.07 & 6.13 & 2.15 & 0.60 & 0.67 & 0.21 & 0.14 & - & - & - \\
\hline 3 & 80.11 & 16.43 & 2.23 & 0.73 & 0.37 & 0.08 & 0.05 & - & - & - & - \\
\hline 4 & 98.91 & 0.60 & 0.23 & 0.11 & 0.09 & 0.05 & 0.01 & - & - & - & $\ldots$ \\
\hline 5 & 96.71 & 2.39 & 0.48 & 0.23 & 0.13 & 0.05 & 0.01 & $\ldots$ & - & - & - \\
\hline
\end{tabular}


of the series. The uppermost sample again is rather poorer. From the foregoing it will appear that the allochthonous admixture has the reverse distribution.

The glauconite-pyrite ratio reveals a steady decline in the glauconite percentage; the lowest, most sandy samples are glauconitic, whereas the upper clayey samples are extremely pyritic. Accordingly, the upper samples in all their characters are a typical Kerteminde marl facies. In Sample 5 a large part of the glauconite and the pyrite is weathered, and it is impossible to make a count of the glauconite-pyrite ratio. This sample however contains both glauconite and pyrite.

The grain distribution. The grain distribution and the distribution curves (Fig. 23) reveal types corresponding to those from Hvalløse. The lower samples, (1 and 2) contain glauconite sand, calcareous mud and allochthonous clay, and the distribution is clearly similar to that in Hvalløse Sample 5, with glauconite grouped about its own maximum, which lies at $0.2 \mathrm{~mm}$ in Sample 1 and at $0.1 \mathrm{~mm}$ in Sample 2. Upwards the glauconitic marl passes into a purely mud facies. Sample 3 still contains some fine sand, whereas the overlying samples are almost free of sand.

\section{Comparison between the Svejstrup and the Hvalløse Series.}

In the series at Vestre Gasværk and Hvalløse, it is easy to see that allochthonous clay and fine sand play scarcely any part in the lowest layers, where the rocks to a great extent consist of anchi-autochthonous lime sand and calcareous mud; it can also be seen that the admixture of the allochthonous component increases upwards in the section. That the facts are different in the lower part of the Svejstrup series, viz. decreasing quantities of allochthonous clay upwards, must be the result of special circumstances. A comparison with the occurrence at Hvalløse which is

Table 13.

Mechanical Analyses recalculated to UdDEN's Scale, Svejstrup.

\begin{tabular}{|c|c|c|c|c|c|c|c|c|c|c|c|c|}
\hline \multirow[b]{2}{*}{$\begin{array}{l}\text { Sample } \\
\text { No. }\end{array}$} & \multicolumn{12}{|c|}{ Diameter in $\mathrm{mm}$} \\
\hline & $\stackrel{0}{\vec{d}}$ & 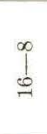 & $\prod_{\infty}^{+}$ & i & $\prod_{-1}$ & $\stackrel{N}{I}$ & $\underset{\vec{r}}{\vec{r}}$ & $\stackrel{\infty}{]}$ & $\stackrel{-}{=}$ & $\stackrel{5}{\stackrel{5}{7}}$ & 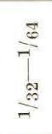 & $\frac{\vec{b}}{3}$ \\
\hline 1 & 2 & 2 & 1 & 1 & 1 & 0 & 2 & 3 & 7 & 11 & 14 & 56 \\
\hline 2 & - & 一 & - & $\div$ & - & 1 & 1 & 1 & 4 & 11 & 18 & 64 \\
\hline 3 & - & - & - & - & - & - & - & 1 & 2 & 6 & 18 & 73 \\
\hline 4 & 一 & - & - & - & - & 一 & - & - & 一 & 1 & 1 & 98 \\
\hline 5 & - & - & - & - & - & - & - & - & 1 & 2 & 5 & 92 \\
\hline
\end{tabular}


only 17 kilometres to the southeast, shows that the lower part of the Svejstrup section is not comparable with that in Hvalløse, whereas it has many points of similarity with the upper series there. In the lower part at Svejstrup and the upper series at Hvalløse there are: 1) decreasing quantities of arenaceous components upwards, 2) increasing quantities of calcium carbonate, and 3) decreasing quantities of allochthonous clay and fine sand upwards in the section, as well as 4) the same grain distribution types in the same order. Consequently we must reckon that the deposits

Table 14.

Quantitative Analyses, Svejstrup.

\begin{tabular}{|c|c|c|c|c|c|c|c|c|c|c|c|c|c|c|c|c|c|}
\hline \multirow[b]{2}{*}{ 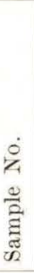 } & \multirow[b]{2}{*}{$\begin{array}{l}\text { Fraction } \\
\text { (diameter } \\
\text { in } \mathrm{mm} \text { ) }\end{array}$} & \multicolumn{5}{|c|}{$\begin{array}{c}1 . \\
\text { Counts of the Composition } \\
\text { of the Fractions }\end{array}$} & \multicolumn{4}{|c|}{$\begin{array}{l}2 . \\
\text { Allochthonous- } \\
\text { Clastic Minerals }\end{array}$} & \multicolumn{2}{|c|}{$\begin{array}{l}3 . \\
\text { Glauconite- } \\
\text { Pyrite Ratio }\end{array}$} & \multicolumn{5}{|c|}{ Grain $\underset{(0 / 00)}{4 .}$} \\
\hline & & 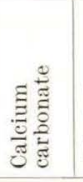 & 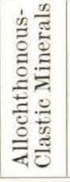 & 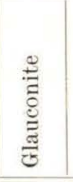 & : & 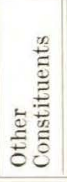 & 䓌 & 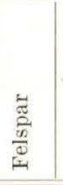 & 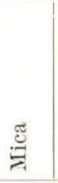 & 苞 & 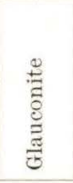 & 䒿 & 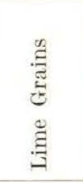 & 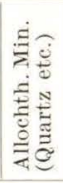 & 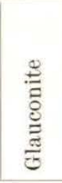 & $\stackrel{8}{5}$ & 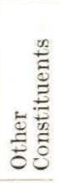 \\
\hline \multirow[t]{5}{*}{1} & $0.02-0.05$ & 63.8 & 26.7 & 3.5 & 0.2 & 5.8 & 93.3 & 4.6 & 1.6 & 0.5 & 93.7 & 6.3 & 103.8 & 43.4 & 5.7 & 0.4 & 9.4 \\
\hline & $0.05-0.10$ & 64.0 & 19.5 & 12.6 & 0.3 & 3.6 & 96.0 & 3.3 & 0.7 & - & 97.5 & 2.5 & 59.1 & 18.0 & 11.6 & 0.3 & 3.3 \\
\hline & $0.1-0.2$ & 32.5 & 0.2 & 67.3 & 一 & 一 & - & - & - & 一 & 100 & $一$ & 9.9 & - & 20.5 & 一 & - \\
\hline & $0.2-0.5$ & 16.0 & - & 84.0 & - & 一 & - & - & - & - & 100 & - & 4.7 & - & 24.7 & 一 & - \\
\hline & $0.5-1.0$ & 42.5 & - & 51.4 & 6.1 & 一 & - & - & - & - & 89.4 & 10.6 & 3.3 & 一 & 4.0 & 0.5 & - \\
\hline \multirow[t]{5}{*}{2} & $0.02-0.05$ & 60.0 & 30.5 & 2.7 & 0.4 & 6.4 & 95.5 & 3.6 & 0.3 & 0.6 & 87.3 & 12.7 & 114.4 & 58.2 & 5.1 & 0.7 & 12.3 \\
\hline & $0.05-0.10$ & 51.8 & 23.4 & 18.8 & 0.8 & 5.2 & 95.8 & 3.0 & 0.6 & 0.6 & 95.9 & 4.1 & 31.7 & 14.4 & 11.5 & 0.5 & 3.2 \\
\hline & $0.1-0.2$ & 35.1 & 0.5 & 64.2 & 0.2 & - & - & - & - & - & 99.7 & 0.3 & 7.6 & 0.1 & 13.8 & - & - \\
\hline & $0.2-0.5$ & 26.7 & tr. & 73.3 & 一 & - & - & - & - & - & 100 & 一 & 1.6 & -- & 4.4 & - & - \\
\hline & $0.5-1.0$ & 41.9 & - & 59.1 & 一 & - & - & 一 & 一 & - & 100 & - & 2.8 & - & 3.9 & 一 & - \\
\hline \multirow[t]{5}{*}{3} & $0.02-0.05$ & 66.2 & 21.7 & 2.3 & 7.0 & 2.8 & 94.1 & 4.1 & 1.3 & 0.5 & 25.1 & 74.9 & 108.8 & 35.7 & 3.8 & 11.4 & 4.6 \\
\hline & $0.05-0.10$ & 48.5 & 12.9 & 3.7 & 33.0 & 1.9 & 94.4 & 3.0 & 2.2 & 0.4 & 10.1 & 89.9 & 10.8 & 2.9 & 0.8 & 7.4 & 0.4 \\
\hline & $0.1-0.2$ & 57.3 & 0.3 & 5.2 & 37.2 & - & - & - & - & - & 12.3 & 87.7 & 4.2 & - & 0.4 & 2.7 & - \\
\hline & $0.2-0.5$ & 36.6 & - & 17.0 & 46.4 & - & - & - & - & - & 26.8 & 73.2 & 1.4 & - & 0.6 & 1.7 & 一 \\
\hline & $0.5-1.0$ & $62.6 *$ & 0.3 & 1.8 & 35.0 & 0.3 & - & - & -- & - & 4.9 & 95.1 & 0.5 & + & 一 & 0.3 & - \\
\hline \multirow[t]{5}{*}{4} & $0.02-0.05$ & 47.3 & 6.1 & 0.2 & 44.3 & 2.1 & 92.9 & 4.4 & 2.7 & . & 0.5 & 99.5 & 2.8 & 0.4 & - & 2.7 & 0.1 \\
\hline & $0.05-0.10$ & 56.9 & 1.1 & tr. & 41.4 & 0.6 & - & - & - & - & 0.1 & 99.9 & 1.3 & - & - & 1.0 & - \\
\hline & $0.1-0.2$ & $73.5 *$ & tr. & tr. & 26.5 & 一 & - & - & - & 一 & 0.1 & 99.9 & 0.8 & - & - & 0.3 & - \\
\hline & $0.2-0.5$ & $43.0 *$ & - & 0.1 & 56.9 & - & - & - & - & - & 0.2 & 99.8 & 0.3 & 一 & - & 0.6 & - \\
\hline & $0.5-1.0$ & $30.5^{*}$ & - & - & 69.5 & - & - & - & - & - & - & 100 & 0.2 & - & - & 0.3 & - \\
\hline \multirow[t]{5}{*}{5} & $0.02-0.05$ & 53.0 & 29.5 & & .7 & 13.8 & 96.4 & 2.0 & 1.5 & 0.1 & - & - & 12.7 & 7.1 & & .8 & 3.3 \\
\hline & $0.05-0.10$ & 54.0 & 2.7 & 35. & & 7.5 & - & - & - & - & - & - & 2.6 & 0.1 & & .7 & 0.4 \\
\hline & $0.1-0.2$ & 54.4 & 1.2 & 43 & & 0.6 & - & - & - & - & - & 一 & 1.3 & - & & .0 & - \\
\hline & $0.2-0.5$ & 41.3 & 一 & 58 & .7 & - & - & - & - & - & - & 一 & 0.5 & - & & 8 & 一 \\
\hline & $0.5-1.0$ & $55.2 *$ & - & 44 & & - & 一 & 一 & - & - & - & 一 & 0.3 & 一 & & .2 & - \\
\hline
\end{tabular}


at Svejstrup correspond to the upper series at Hvalløse. Therefore, either the strata that correspond to the lower Hvalløse series have not been deposited at Svejstrup or they have been completely disintegrated by the new transgression. The complete conformity in the character of the limestone pebbles in the two bottom deposits makes it probable that the latter has been the case, so that the rather few pebbles at Svejstrup have been redeposited from an older gravel deposit.

The differences between the two series are due to the different substrata and disintegrated rocks. At Hvalløse, where the upper series rests upon fine Paleocene marl, the sandy stratum is only of slight thickness; at Svejstrup, where the series rests upon Danian coccolith chalk, and where possibly the lower sandy Paleocene series has been broken down, a sandy marl has been developed with a few pebbles and a higher content of calcium carbonate, and the sandy marl has acquired a greater thickness.

The Svejstrup occurrence reveals the continuation of the Paleocene series
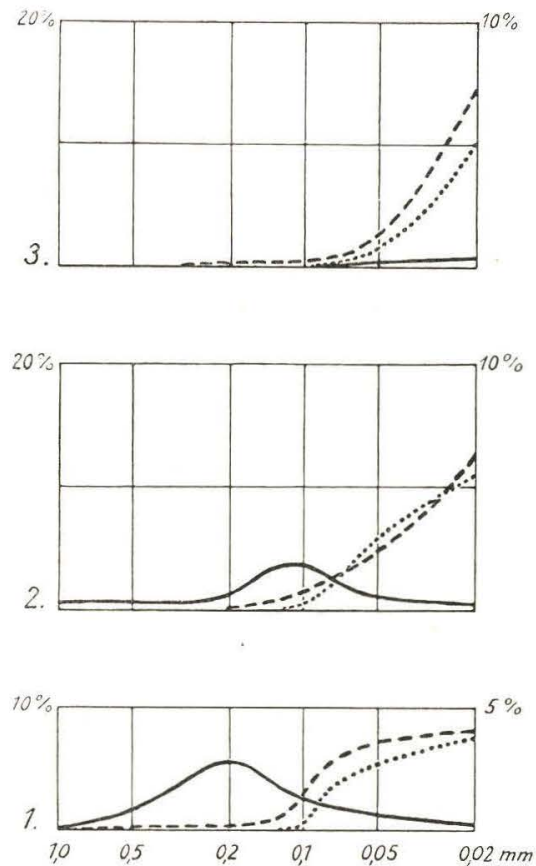

Fig. 23. Distribution curves, Svejstrup. -.-.-- Lime sand; - Glauconite; ........... Allochthonous sand (Quartz etc.). For further explanation see Fig. 11 page 53.

upwards. A very fine-grained marl has developed, one that is pyritic and contains an abundance of transformed diatoms, so that it is a normal Kerteminde marl type.

\section{Ommestrup.}

The dislocated occurrence exposed at Ommestrup lies about $3 \mathrm{~km}$ ESE of Mørke Station. The Paleocene rocks form the core of a hill and have been thrust and folded by the ice from the south. An examination made in 1931 and a supplementary visit in 1934 revealed the following:

The south wall of the pit was of black-grey marl, whereas the north wall consisted of whitish marl. Between these walls, in the east wall, was a fold comprising various kinds of marl overlain by moraine deposits. (Fig. 24). The axis of the fold, which was horizontal, trends from S. 70 E. to N. $70 \mathrm{~W}$., that is to say almost parallel with the marginal line of the East Jutland ice. (Fig. 17 page 79). 
Reckoning from the north side the following rocks were found:

1. Whitish-yellow, weathered, fat marl of the same character as in the north wall. By means of mottled transitional strata it is connected with

2. Black-grey, fat, shiny marl (1.1 m thick). Then follows a rather distinct boundary against

3. Light grey, somewhat sandy marl, with large glauconite grains $(0.6 \mathrm{~m})$, which passes smoothly into

4. Light grey, somewhat sandy marl $(1.1 \mathrm{~m})$, which again passes into

5. Dark grey, rather sandy marl of the same character as that in the south wall. This stratum forms the innermost part of the fold, where it is visible with a thickness of about $0.6 \mathrm{~m}$.

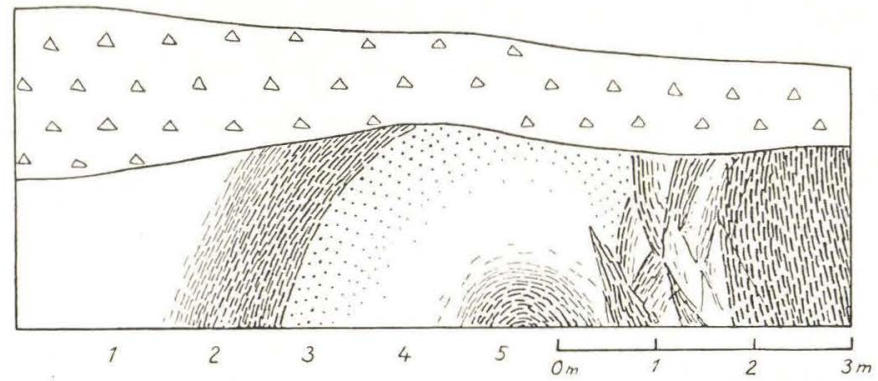

Fig. 24. Ommestrup. East wall of the pit. Numbers as in text.

Whereas the strata from north to the middle of the section follow each other naturally, in the south part there is a badly disturbed zone with alternating lighter and darker parts, separated by numerous oblique faults cutting into one another. The position of the strata makes it scarcely possible to decide which deposits are the oldest, but all the analyses, both mechanical analyses and mineralogical counts, indicate that Stratum 1 is the oldest, Stratum 5 the youngest.

\section{Mechanical Analyses.}

The analyses (Table 15) show that all the samples mostly consist of grains of a diameter under $0.02 \mathrm{~mm}$. The sandy components group with increasing quantities in the finest fractions. If we take it that Stratum 1 is the oldest, we get first an argillaceous series (Samples 1 and 2), overlying which is a sedimentation boundary, observable through a new supply of coarser material. Over this boundary the sand content decreases gradually upwards. The mechanical analyses and the alternation of the rocks are analogous to conditions round about the sedimentation boundary in the Hvalløse locality.

Mineral Content and Quantitative Proportions (Table 16).

The mineral content is the usual one in Paleocene rocks. In the coarsest fractions the calcareous components are exclusively, or almost 
Table 15 .

Mechanical Analyses, Ommestrup.

\begin{tabular}{|c|c|c|c|c|c|c|c|c|}
\hline \multirow[b]{2}{*}{$\begin{array}{c}\text { Sample } \\
\text { No. }\end{array}$} & \multicolumn{8}{|c|}{ Diameter in $\mathrm{mm}$} \\
\hline & 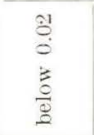 & $\begin{array}{l}\hat{s} \\
\stackrel{0}{0} \\
\hat{0} \\
\stackrel{0}{0}\end{array}$ & $\begin{array}{l}0 \\
0 \\
0 \\
0 \\
0\end{array}$ & $\frac{9}{i}$ & $\stackrel{10}{0}$ & $\begin{array}{l}0 \\
10 \\
0 \\
0\end{array}$ & $\stackrel{1}{I}$ & $\prod_{\infty}^{10}$ \\
\hline 1 & 93.74 & 5.52 & 0.42 & 0.20 & 0.08 & 0.03 & 0.01 & - \\
\hline 2 & 94.77 & 4.32 & 0.37 & 0.28 & 0.21 & 0.04 & 0.01 & - \\
\hline 3 & 70.92 & 16.03 & 5.31 & 3.75 & 3.67 & 0.20 & 0.07 & 0.05 \\
\hline 4 & 73.78 & 21.06 & 4.25 & 0.58 & 0.20 & 0.08 & 0.05 & - \\
\hline 5 & 83.23 & 14.85 & 1.32 & 0.30 & 0.24 & 0.03 & 0.03 & - \\
\hline
\end{tabular}

exclusively, fresh foraminifera. In the finer fractions, however, anchiautochthonous-clastic calcareous components predominate, no doubt exclusively of organic origin. In the mud there are coccoliths as well as small, clear grains of calcite.

The quantities of calcium carbonate in the samples and in the mud (see table below) keep very close together. The rock just under the sedimentation boundary is rather poor in calcium carbonate; over the boundary where the rocks are sandy the calcium carbonate content increases and remains almost constant.

Calcium Carbonate Percentages.

\begin{tabular}{l|c|c|c|c|c}
\hline \multicolumn{1}{c|}{ Sample No. } & 1 & 2 & 3 & 4 & 5 \\
\hline \hline Raw Sample & 57.5 & 25.5 & 42.1 & 41.6 & 41.0 \\
Mud & 57.2 & 24.9 & 39.4 & 35.8 & 37.4 \\
\hline
\end{tabular}

The allochthonous-clastic components are as usual. Both percentually and absolutely there are most in the finest fractions. Glauconite as usual occurs mostly in the form of rounded and lobate grains, pyrite occurs as concretions which are always built up of small spheres. The exterior shape often reveals that it was formed in sponge spicules, and in the dark marl — as in Kerteminde marl — there are many having the form of diatoms. The other components are mostly silicified rock fragments, with subordinate sponge spicules.

The glauconite-pyrite ratio in the various rocks displays a marked facies-alternation between glauconitic and pyritic rocks. Lowest there is mainly glauconite (Sample 1, see table p. 101), and above it pyrite (Sample 2). The three more arenaceous rocks form a single series, begin- 
ning with much glauconite, but with a gradually higher pyrite content upwards in the section.

In Sample 1, which is much weathered, there are only very few fresh glauconite and pyrite particles, but on the other hand many limonitecoloured weathering products. Though the rock is weathered almost right through, it has been possible to take a very small sample in which the glauconite and pyrite were preserved. In this I made a count of the glauconite-pyrite ratio and compared it with the count of glauconite,

Table 16.

Quantitative Analyses, Ommestrup.

\begin{tabular}{|c|c|c|c|c|c|c|c|c|c|c|c|c|c|c|c|c|c|}
\hline \multirow[b]{2}{*}{$\begin{array}{l}\stackrel{\circ}{14} \\
\stackrel{0}{2}\end{array}$} & \multirow[b]{2}{*}{$\begin{array}{l}\text { Fraction } \\
\text { (diameter } \\
\text { in } \mathrm{mm} \text { ) }\end{array}$} & \multicolumn{5}{|c|}{$\begin{array}{c}1 . \\
\text { Counts of the Composition } \\
\text { of the Fractions }\end{array}$} & \multicolumn{4}{|c|}{$\begin{array}{l}2 . \\
\text { Allochthonous- } \\
\text { Clastic Minerals }\end{array}$} & \multicolumn{2}{|c|}{$\begin{array}{c}3 . \\
\text { Glauconite- } \\
\text { Pyrite Ratio }\end{array}$} & \multicolumn{5}{|c|}{ Grain Distribution } \\
\hline & & 竎 & 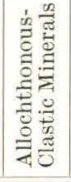 & 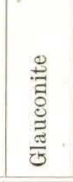 & $\stackrel{\$}{\overparen{E}}$ & 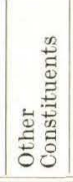 & 范 & 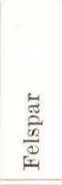 & 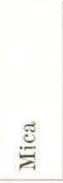 & $\frac{\infty}{0}$ & 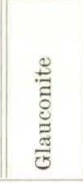 & 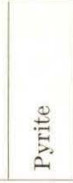 & 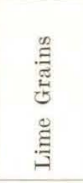 & 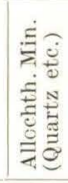 & 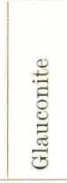 & $\stackrel{\mathscr{E}}{\stackrel{E}{E}}$ & 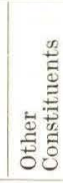 \\
\hline \multirow[t]{5}{*}{1} & $0.02-0.05$ & 61.8 & 25.1 & \multicolumn{2}{|c|}{5.0} & 8.1 & 90.9 & 8.3 & 0.6 & 0.2 & - & - & 34.1 & 13.9 & \multicolumn{2}{|c|}{2.7} & 4.5 \\
\hline & $0.05-0.10$ & $64.4^{*}$ & 9.0 & \multicolumn{2}{|c|}{22.6} & 4.0 & 85.2 & 13.9 & 0.9 & - & - & - & 2.6 & 0.4 & \multicolumn{2}{|c|}{1.0} & 0.2 \\
\hline & $0.1-0.2$ & $60.0^{*}$ & 4.9 & \multicolumn{2}{|c|}{34.9} & 0.2 & - & - & - & - & - & $\longrightarrow$ & 1.2 & 0.1 & \multicolumn{2}{|c|}{0.7} & 一 \\
\hline & $0.2-0.5$ & $57.6 *$ & 0.3 & \multicolumn{2}{|c|}{41.2} & 0.9 & 一 & 一 &.- & - & 一 & 一 & 0.5 & - & \multicolumn{2}{|c|}{0.3} & - \\
\hline & $0.5-1.0$ & $95.6^{*}$ & - & \multicolumn{2}{|c|}{ - } & 4.4 & 一 & - & - & - & - & 一 & 0.3 & - & \multicolumn{2}{|c|}{-} & - \\
\hline \multirow[t]{5}{*}{2} & $0.02-0.05$ & 36.3 & 31.3 & 7.7 & 24.6 & 0.1 & 90.6 & 2.5 & 6.9 & - & 23.8 & 76.2 & 15.7 & 13.5 & 3.3 & 10.6 & 0.1 \\
\hline & $0.05-0.10$ & $55.5^{*}$ & 2.0 & 6.6 & 35.1 & 0.8 & 87.3 & 7.2 & 5.5 & - & 15.8 & 84.2 & 2.1 & 0.1 & 0.2 & 1.3 & 一 \\
\hline & $0.1-0.2$ & $20.5 *$ & 0.3 & 6.0 & 73.0 & 0.2 & - & 一 & - & - & 7.6 & 92.4 & 0.6 & - & 0.2 & 2.0 & - \\
\hline & $0.2-0.5$ & $24.0^{*}$ & 0.7 & - & 75.0 & 0.3 & - & - & - & - & - & 100 & 0.5 & - & - & 1.6 & -- \\
\hline & $0.5-1.0$ & $44.7 *$ & 1.0 & 3.5 & 50.8 & 一 & 一 & - & - & 一 & 6.5 & 93.5 & 0.2 & - & - & 0.2 & 一 \\
\hline \multirow[t]{5}{*}{3} & $0.02-0.05$ & 62.2 & 29.3 & 4.2 & 0.1 & 4.2 & 93.3 & 4.3 & 1.6 & 0.8 & 97.2 & 2.8 & 99.7 & 47.0 & 6.7 & 0.2 & 6.7 \\
\hline & $0.05-0.10$ & 57.5 & 16.8 & 19.6 & 1.1 & 5.0 & 93.4 & 6.0 & 0.6 & - & 94.9 & 5.1 & 30.5 & 8.9 & 10.4 & 0.6 & 2.7 \\
\hline & $0.1-0.2$ & 13.9 & tr. & 86.1 & - & 一 & - & - & - & 一 & 100 & - & 5.2 & - & 32.3 & - & 一 \\
\hline & $0.2-0.5$ & 8.3 & - & 91.7 & - & - & - & - & - & - & 100 & - & 3.0 & 一 & 33.7 & -- & - \\
\hline & $0.5-1.0$ & $88.8^{*}$ & 0.1 & 10.8 & -- & 一 & - & - & - & - & 100 & - & 1.8 & $\cdots$ & 0.2 & - & - \\
\hline \multirow[t]{5}{*}{4} & $0.02-0.05$ & 57.3 & 31.5 & 1.8 & 0.7 & 8.7 & 93.0 & 5.4 & 1.6 & 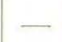 & 73.3 & 26.7 & 120.7 & 66.4 & 3.8 & 1.4 & 18.3 \\
\hline & $0.05-0.10$ & 52.5 & 17.7 & 21.6 & 0.2 & 8.0 & 92.9 & 6.8 & 0.3 & 一 & 99.0 & 1.0 & 22.3 & 7.5 & 9.2 & 0.1 & 3.4 \\
\hline & $0.1-0.2$ & $97.2 *$ & tr. & 2.6 & 0.1 & 0.1 & - & - & - & 一 & 98.2 & 1.8 & 5.6 & - & 0.2 & 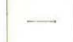 & - \\
\hline & $0.2-0.5$ & $84.5 *$ & 2.5 & 2.6 & 0.4 & 10.0 & 98 & 2 & - & - & c. 85 & c. 15 & 1.6 & 0.1 & 0.1 & - & 0.2 \\
\hline & $0.5-1.0$ & $93.9 *$ & 0.4 & 0.7 & - & 5.0 & - & - & - & - & - & - & 0.8 & - & - & - & 一 \\
\hline \multirow[t]{5}{*}{5} & $0.02-0.05$ & 58.0 & 31.3 & 3.5 & 7.2 & - & 94.1 & 3.6 & 2.1 & 0.2 & 33.7 & 66.3 & 86.1 & 46.5 & 5.2 & 10.7 & 一 \\
\hline & $0.05-0.10$ & 61.0 & 12.9 & 1.3 & 20.6 & 4.2 & 90.9 & 2.1 & 7.0 & - & 6.0 & 94.0 & 8.1 & 1.7 & 0.2 & 2.7 & 0.5 \\
\hline & $0.1-0.2$ & $89.6^{*}$ & 0.1 & 0.1 & 11.0 & 0.2 & 100 & - & - & - & 0.1 & 99.9 & 2.7 & 一 & 一 & 0.3 & 一 \\
\hline & $0.2-0.5$ & $51.1 *$ & 1.1 & 一 & 47.8 & - & $一$ & - & - & - & 一 & 100 & 1.2 & 0.1 & -- & 1.1 & - \\
\hline & $0.5-1.0$ & $100^{*}$ & - & 一 & - & 一 & - & - & - & - & -- & - & 0.3 & - & - & - & 一 \\
\hline
\end{tabular}


pyrite and brown grains in the weathered sample. The counts revealed the following percentual compositions:

\begin{tabular}{r||c|c|c||c|c}
\hline Ommestrup 1 & \multicolumn{3}{|c||}{ Weathered Sample } & \multicolumn{2}{c}{ Fresh Sample } \\
\hline Grain size & Brown grains & Glauconite & Pyrite & Glauconite & Pyrite \\
\hline \hline $0.02-0.05 \mathrm{~mm}$ & 69.5 & 11.0 & 195 & 84.0 & 16.0 \\
$0.05-0.10$, & 75.0 & 18.4 & 6.6 & 82.7 & 17.3 \\
$0.1-0.2$, & 80.0 & 9.5 & 10.5 & 100 & 0 \\
$0.2-0.5 \quad "$ & 100 & 0 & 0 & 100 & 0 \\
\hline
\end{tabular}

The table shows very clearly that to a very great extent the brown grains must have been formed of glauconite.

These brown grains consist partly of limonite, for they have the brown colour and high refractive index of limonite and are single-refracting. With high magnification, however, it can be seen that a large number of the grains also contain a clear, colourless, single-refracting substance with a low refractive index, whilst some grains consist almost exclusively of this substance. If the grains are treated with hydrochloric acid the limonite dissolves, but the grains retain their exterior form in all essentials. They then consist of an irregularly built, spongy mass or an accumulation of sharp-edged particles of the clear substance which, judging from the optical characters, apparently must be amorphous silica. - Among the more fresh glauconite grains some are more or less brown at the edge, as described by CAYeux (1916) and Berz (1921). Thus the sample contains all transitions from fresh glauconite, through more or less brown-tinted grains, to those consisting mainly of silica. - The same transformations have also been observed - though to a much smaller extent - in other glauconitic Paleocene rocks that were less weathered.

The literature contains different views on the weathering of glauconite. Kuемм (1882) states that glauconite is converted into limonite. According to GLINKA (1896) calcium, potassium, magnesium and iron are dissolved during the weathering process, and the final product is ferruginous clay. According to CAYEUX (1916) limonite is first formed, but in the case of complete disintegration all the constituents (including silica and iron) dissolve. Berz, too, considers that the glauconite weathers away entirely, and that limonite is formed during the weathering process (1921). He has furthermore found a weathering process corresponding exactly to that in the Paleocene, having analysed brown iron compounds from glauconitic deposits at Kressenberger. He writes (1921, page 92) (in translation) "On treating the ore grains with hydrochloric acid a decolorization gradually sets in, the iron oxide and some silicic acid dissolve, and there remain whitish particles unchanged in form. They consist of amorphous silica." 
The conformity between BERz's investigations and mine makes it probable that it is a rather common occurrence that both limonite and silica are formed when glauconite weathers. These substances may thereafter decompose, as shown by CAYEux and Berz.
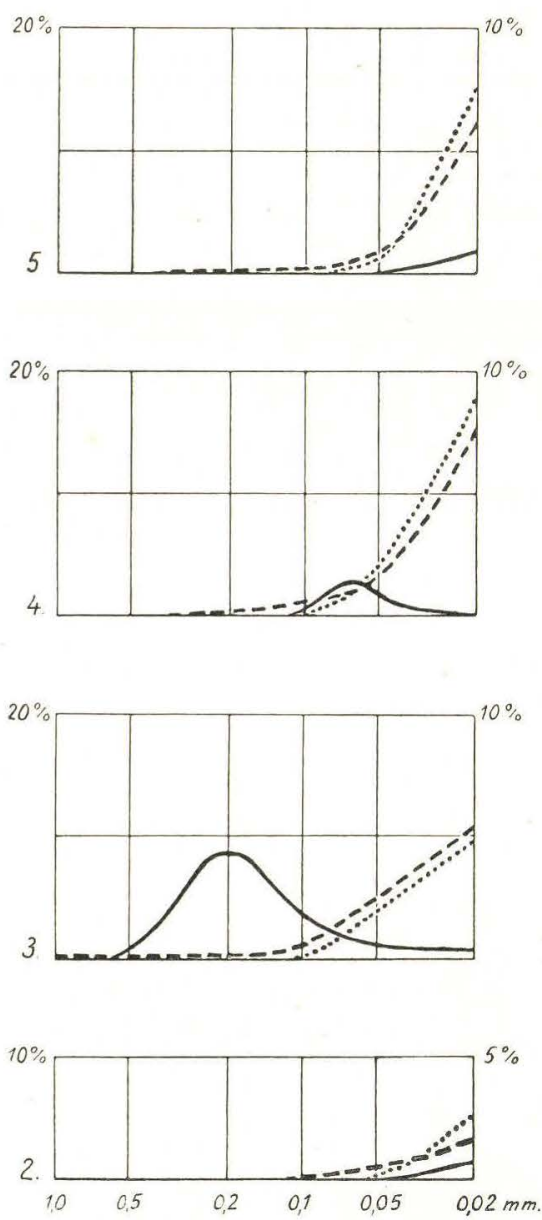

Fig. 25. Distribution curves, Ommestrup.

-...- Lime sand; - Glauconite;

Allochthonous sand (Quartz etc.)

For further explanation see Fig. 11 page 53.

The grain distribution and the distribution curves (Fig. 25) display features recalling parts of the Hvalløse and Svejstrup series, if as before we reckon Stratum 1 as being the oldest.

Samples 1 and 2 are typical mud facies with very few and fine sandy components. Overlying them, as at Hvalløse, is a more sandy series, commencing with a rock characterised by the combination glauconite sand, calcareous mud, terrigenous clay, and with the previously described distribution with the glauconite grouped about its own maximum, which in this case lies at $0.2 \mathrm{~mm}$ (Ommestrup 3 corresponding to Hvalløse 5 and Svejstrup 1). The overlying rock (Sample 4) contains the same combination but fewer and smaller glauconite particles (corresponding to Svejstrup 2), and finally the uppermost sample again is a mud facies with regard to the three more or less transported components.

Hvalløse, Svejstrup and Ommestrup have a number of features in common which seem to be particularly associated with circumstances peculiar to transgressions. At Hvalløse and Ommestrup a more sandy series overlies a mud deposit. At all three localities the rocks immediately above the transgression boundary are characterised by their content of glauconite sand. The main grain size of this sand becomes smaller upwards (Svejstrup, Ommestrup), presumably as less agitated conditions set in in the water, and finally the rock passes into a genuine mud facies. At Svejstrup and Ommestrup there is a distinct transition from glauconitic rocks in the bottom of the series to pyritic rocks at the top. 
As stated, these common features undoubtedly are connected with a new transgression and erosion of older rocks, but where we merely have these rock characteristics to guide us we naturally cannot deduce the absolute age of the deposits. In fact, it is presumable that transgressions and fluctuations in the erosion have taken place several times, and each time with the forming of the same rock types in the same order of succession. In this way it is possible for a considerable alternation of facies to occur between arenaceous glauconitic and argillaceous pyritic rocks.

\section{Holme.}

This locality is a marl pit, lying near the beach opposite Holme, about $2 \mathrm{~km}$ southwest of Jernhatten. It contains alternating strata of fat marl and hard, silicified rocks. The strata lie almost horizontally. From the bottom the series is as follows:

1. Hard, silicified limestone, light greyish with a yellowish tinge. The rock mostly resembles the greensand-stone at Lellinge, but it is finer in grain. There is also a distinct similarity to the hard rocks at Hanerup, but the Holme rock is coarser and more sandy. In the bottom of the pit $0.5 \mathrm{~m}$ of this rock is visible. The stratum passes upwards into

2. Grey, slightly sandy marl (thickness $0.3 \mathrm{~m}$ ). After a very thin transitional zone consisting of a mottled rock the marl is overlain by

3. A light limestone of the same type as Stratum $1(0.3 \mathrm{~m})$. At the top this limestone passes insensibly through mottled strata into

4. Dark grey, fat marl, almost black when in moist condition $(0.7 \mathrm{~m})$.

Over this is a sharp boundary against

5. Light grey limestone, which passes gradually upwards into a darker and more clayey rock (in all $0.65 \mathrm{~m}$ ). Then a sharp boundary against

6. Light limestone of quite the same type as 1,3 and $5(0.5 \mathrm{~m})$. It is sharply delimited from a marl series $4 \mathrm{~m}$ thick, which at the bottom consists of

7. Dark grey marl, of a type almost the same as Stratum 4 (Sample 7 was taken $0.2 \mathrm{~m}$ over the boundary against the limestone). The dark marl passes quickly into

8. Lighter grey marl (Sample 8 taken $1.2 \mathrm{~m}$ over the limestone), and at the top into

9. Whitish-grey marl (Sample 9 taken $3.0 \mathrm{~m}$ above the limestone). 


\section{The Rock-Types.}

The soft marl types are all rather fat marls (though Stratum 2 is slightly sandy) containing fine calcareous sand, very little quartz sand, few glauconite grains and abundant quantities of pyrite, which occurs in the form of concretions, as triangular or disk-shaped bodies or as sponge spicules, and which consists of tiny spheres as in the Kerteminde marl.

The hard rocks. Slides of the hard rocks show that all the hard sediments are of the same type, being built up of densely packed calcareous shell fragments lying in a fine-grained silicified mass together with some few quartz grains and a quantity of glauconite grains.

Among the lime particles are numerous foraminifera, some of them whole, others in fragments, as well as bryozoan remains and other lime grains of a structure which cannot exactly be defined, as they consist eithêr of a single calcite crystal or of a fine-grained aggregate. In most cases the lime grains are of a size round about $0.05-0.1 \mathrm{~mm}$, but actually the size varies a great deal. Quartz occurs subordinately in the form of small, sharp-edged splinters up to $0.03-0.05 \mathrm{~mm}$ in diameter. Glauconite is scattered about in the rock as round or lobate grains, the size of which lies about $0.05 \mathrm{~mm}$. Pyrite occurs mostly as a fine pigment in the shells, subordinately in the form of small, irregularly shaped concretions, but is of no great importance. The quantity of sponge spicules varies extraordinarily, certain portions of the rocks being almost free of spicules, whereas in others they are common. Sometimes we find the spicules preserved as opal, but as a general rule they are dissolved, and then their place is marked by holes in the rock. The matrix contains numerous fine calcareous grains and shell remains, lying in a uniformly light brownish mass consisting of amorphous silica.

The glauconite-pyrite ratio. As the Holme series contains a quantity of silicified rocks, which do not lend themselves to elutriation, and the mechanical analyses are of most account where by means of the results it is possible to show variations from stratum to stratum, no mechanical analyses have been made on any of the rocks from Holme. Nevertheless, in order to get to know more about the nature of the alternation of the rocks than can be deduced from the foregoing description, I have examined the ratio between the glauconite and the pyrite grains. The grains examined have a size of about $0.05 \mathrm{~mm}$. The result is contained in the following table, together with particulars of the calcium carbonate content of the samples, and shown graphically in the section drawing Fig. 26.

The table and the section drawing show that at Holme there is a very considerable facies alternation, expressed in both the sand content and the glauconite-pyrite ratio. On the other hand the calcium carbonate 


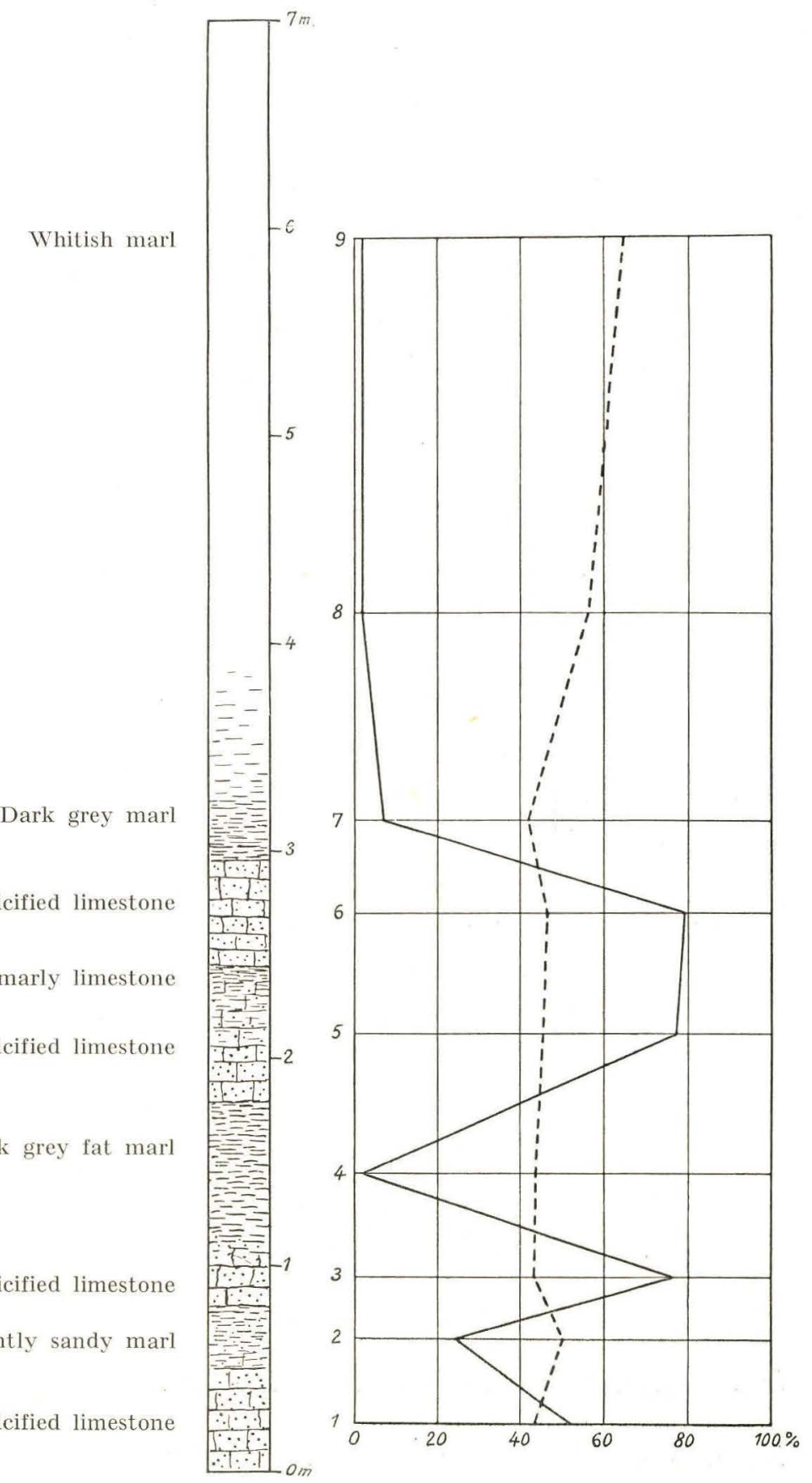

Fig. 26. Holme. Section showing calcium carbonate content (broken line) and glauconite content (continuous line). 


\begin{tabular}{l|l|l|l|l|l|l|l|c|c}
\hline \multicolumn{1}{c|}{ Sample No. } & \multicolumn{1}{c|}{1} & \multicolumn{1}{c|}{2} & 3 & 4 & 5 & 6 & 7 & 8 & 9 \\
\hline \hline Glauconite \% & 52 & 24 & 76 & 2 & 77 & 79 & 7 & 2 & 2 \\
Pyrite \% $\%$ & 48 & 76 & 24 & 98 & 23 & 21 & 93 & 98 & 98 \\
Calcium carb. \% & 43.3 & 50.3 & 43.4 & 43.5 & 45.4 & 46.3 & 41.8 & 56.2 & 64.3 \\
\hline
\end{tabular}

content does not tell us much, nor indeed could we expect it to do so, as some of the rocks are very much silicified.

An examination of the series shows that the sandy samples are also richest in glauconite, and thus very closely approach the greensand in Sealand, whilst the clayey samples contain pyrite and are very close to Kerteminde marl in type. The impression one receives at Holme is that there is a succession of sedimentation series, each beginning with sandy, glauconitic strata but rapidly passing upwards into clayey, pyritic sediments, viz. conditions reminiscent of the series at Hvalløse and Ommestrup. At any rate it is certain that conditions on the sea floor during the deposition of the strata have varied greatly. The glauconitic, sandy deposits must have been laid down in agitated oxygenous water, whereas the pyritic mud deposits were laid down in still and non-oxygenous water.

It is not only in the composition of the rocks that the physical conditions have asserted themselves, but also in the fossil content of the deposits. No detailed account of this will be presented in this purely petrographical work, but mention must be made of the fact that the sandy, glauconitic rocks contain a much richer fauna than the clayey, pyritic rocks, as will appear from the following summary:

Stratum 1. Sand-glauconite facies. Rather rich in fossils, mostly gasteropods.

Stratum 2. Intermediate facies, more pyritic than anything. Contains a number of Lima testis, hardly any other fossils, a single Dentalium.

Stratum 3. Sand-glauconite facies. Numerous fossils with a fauna corresponding to the Rugaard fauna, especially gasteropods.

Stratum 4. Mud-pyrite facies. Only very few fossils found, viz. two or three specimens of a Nucula and one Natica.

Strata 5 and 6 . Sand-glauconite facies. Numerous gasteropods ete. as in Stratum 3.

Strata 7-9. Mud-pyrite facies. Only few fossils found in the whole series, a Nucula and one or two Dentalium.

Thus it is evident that the fauna to a very great extent depends upon the facies, a circumstance which without doubt also holds good of the 
other Danish Paleocene deposits. Accordingly it will scarcely be possible to arrive at a real age determination of the Kerteminde marl in relation for instance to Vestre Gasværk or Lellinge by paleontological means. The fact that the Vestre Gasværk series and the Lellinge and Rugaard occurrences are rich in fossils, whereas the marls at Kerteminde and Hanerup are very poor, is certainly due for the most part to the facies conditions. Grönwall expressed a similar view as early as in 1902 (in V. Madsen 1902).

\section{Rugaard.}

The Paleocene at Rugaard has been described by GrönwaLL and Harder (1907). According to these authors, the Paleocene is exposed in cliffs and creep-terraces between Rugaard and Jernhatten. Farthest north is Paleocene marl, and there two sections were dug; they revealed that the Paleocene consisted of alternating layers of fat grey marl and more sandy marl with many hard, concretionary portions arranged in strata. The series was fossiliferous, and the hard portions especially contained many fossils, whereas the soft marl had only very few.

At several places south of the marl occurrence GrönwALL and HARDER found darker or lighter grey, slightly sandy, non-calcareous clay containing caleareous grey concretionary portions. Of these rocks GrönwaLL and HARDER stated that they were probably to be placed to the younger Paleocene, an opinion that was confirmed later by the finding of similar rocks in boring sections (GRÖNWALL 1908).

On the marl and the consolidated rocks Grönwall and Harder say (in translation):

"As regards the petrographic character of the stone it may on the whole be said that the greyish (or blueish) and clayey varieties agree in every way with the Kerteminde marl, whereas the yellowish, harder and coarser-grained varieties more resemble the Lellinge greensand and the Paleocene rocks at Copenhagen. It will be difficult to decide how much of this difference is original. To a great extent the colour is undoubtedly connected with the degree of oxygenization of the iron compounds, and it is scarcely safe to assume that this is original. The harder varieties are impregnated with calcium carbonate or amorphous silica, or perhaps both... There is thus reason for assuming that at Rugaard the Paleocene was deposited in the form of a fairly homogenous clayey mud with a few more arenaceous and glauconitic layers."

Judging from GRÖNWALL and HARDER's description there is no doubt that facies similar to those at Holme are to be found at Rugaard. 
When I saw the locality in 1931 the marl section had slipped and was quite overgrown, but it was possible to see the non-calcareous Paleocene at several places in the cliffs, in all cases in a much disturbed state. There was a distinct alternation between soft beds of grey sandy clay and hard silicified beds. The rock in the hard beds is intersected with cracks in various directions, with the result that the rock breaks into angular fragments, of which the surfaces are often crusted with crystals of gypsum. In the grey clay, too, one frequently finds newly formed crystals several centimetres in length.

The petrographical examinations show that in all their features the rocks have a typical Paleocene character, except that the calcium carbonate content is very low, or even nil. A mechanical analysis has been made with a sample of the clay, and the hard rocks have been examined in thin sections.

\section{The Grey Sandy Clay.}

The mechanical analysis (Tables 17 and 18; Fig. 27) shows that the sample is sandy clay, in which the sand particles are grouped about a pronounced maximum in the fraction $0.05-0.10 \mathrm{~mm}$. The mud content is only about $60 \%$, which means that the rock is much more sandy than the Paleocene marly rocks in the vicinity.

The mineral content is the same as in the normal Paleocene samples. The calcium carbonate content in the clay sample examined is $1.0 \%$, and most of it is in the mud. The allochthonous-clastic sand particles are mostly angular quartz grains, and subordinately there are felspar (orthoclase, microcline and plagioclase), white mica and tourmaline. Glauconite is present as rounded and lobate grains, pyrite as accidentally formed concretions. Gypsum occurs subordinately as crystals. Of organic remains sponge spicules are common, radiolaria rather rare. (The greater part of those counted under "other constituents" are sponge spicules).

Table 17.

Mechanical Analysis, Rugaard.

\begin{tabular}{|c|c|c|c|c|}
\hline \multicolumn{5}{|c|}{ Diameter in $\mathrm{mm}$} \\
\hline $\begin{array}{l}3 \\
0 \\
0 \\
0 \\
5 \\
0 \\
0 \\
\end{array}$ & $\begin{array}{l}\stackrel{8}{8} \\
\stackrel{0}{0} \\
\hat{\delta} \\
0\end{array}$ & $\begin{array}{l}\stackrel{8}{0} \\
0 \\
1 \\
0 \\
0\end{array}$ & $\begin{array}{c}\text { 9! } \\
0 \\
-1 \\
0\end{array}$ & $\begin{array}{l}13 \\
0 \\
0\end{array}$ \\
\hline 59.87 & 7.76 & 31.50 & 0.81 & 0.06 \\
\hline
\end{tabular}


Quantitative proportions. (Table 19; Fig. 28). It appears from the counts that the allochthonous-clastic minerals represent the greater part of the sandy particles, the remainder mostly being glauconite grains and siliceous organisms. The proportions of the various allochthonous-clastic minerals are the usual in the Paleocene. The glauconite-pyrite ratio shows that glauconite is greatly preponderant.

The grain distribution and the distribution curves show that the allochthonous minerals and the glauconite grains group themselves in exactly the same way about a maximum in the fraction $0.05-0.10 \mathrm{~mm}$. This complete agreement of the size of the allochthonous grains and the glauconite grains shows that both minerals have been trans-

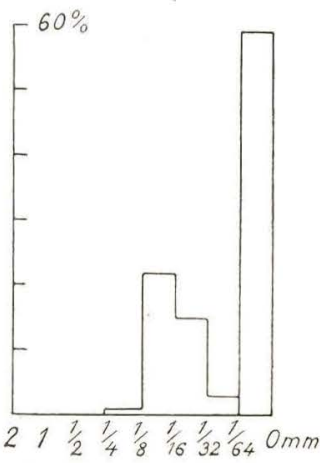

Fig. 27. Distribution pyramid, Rugaard. ported and sorted together.

\section{The Consolidated Rocks.}

Of the consolidated rocks three samples have been examined, taken from different places in the cliffs. The rock is the same in all three samples, the only variation found being that two of the samples were quite free of calcium carbonate, whereas the third contained $5.0 \%$.

Thin sections of the samples (Plate 2, Fig. 6) revealed that the rocks are sandstone, in which the sand particles lie at some distance apart. Most of the sand particles are quartz and glauconite grains well sorted and with a main grain size of from 0.05 to $0.07 \mathrm{~mm}$. More subordinately there are sponge spicules and pyrite. The sandy particles lie in a fine brownish matrix.

Where calcium carbonate is present it occurs partly as small foraminifera, partly as irregular grains and as fine grains in the brownish matrix. The allochthonous-clastic sand grains are almost always sharp-edged. The

Table 18.

Mechanical Analysis recalculated to Udden's Scale, Rugaard.

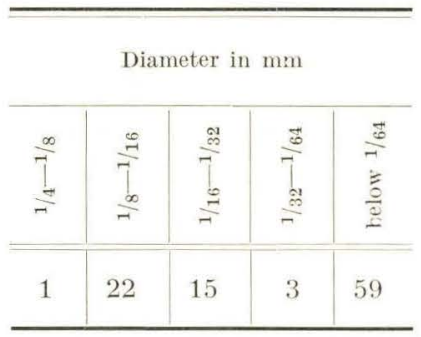


Table 19

Quantitative Analysis, Rugaard.

\begin{tabular}{|c|c|c|c|c|c|c|c|c|c|c|c|c|c|c|c|c|}
\hline \multirow[b]{2}{*}{$\begin{array}{c}\text { Fraction } \\
\text { (diameter } \\
\text { in } \mathrm{mm} \text { ) }\end{array}$} & \multicolumn{5}{|c|}{$\begin{array}{c}1 . \\
\text { Counts of the Composition } \\
\text { of the Fractions }\end{array}$} & \multicolumn{4}{|c|}{$\begin{array}{l}2 \text {. } \\
\text { Allochthonous- } \\
\text { Clastic Minerals }\end{array}$} & \multicolumn{2}{|c|}{$\begin{array}{l}3 . \\
\text { Glauconite- } \\
\text { Pyrite Ratio }\end{array}$} & \multicolumn{5}{|c|}{ Grain $\underset{(0 / 00)}{4 .}$} \\
\hline & 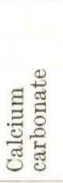 & 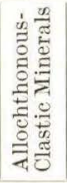 & 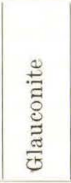 & $\underset{\mathscr{E}}{\stackrel{ \pm}{5}}$ & 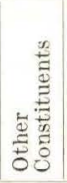 & 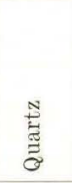 & 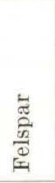 & $\stackrel{\mathscr{J}}{=}$ & 常 & 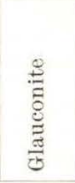 & $\frac{1}{5}$ & 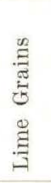 & 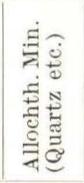 & 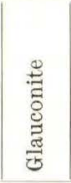 & 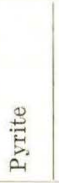 & 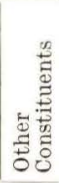 \\
\hline $0.02-0.05$ & 0.2 & 70.7 & 10.2 & 1.2 & 17.7 & 95.8 & 2.0 & 1.7 & 0.5 & 89.2 & 10.8 & 0.1 & 54.9 & 7.9 & 1.0 & 13.7 \\
\hline $0.05-0.10$ & - & 75.5 & 10.8 & 1.4 & 12.3 & 94.8 & 2.6 & 1.7 & 0.9 & 88.3 & 11.7 & - & 237.7 & 33.9 & 4.5 & 38.9 \\
\hline $0.1-0.2$ & - & 39.9 & 20.0 & 1.2 & 38.9 & 97.5 & 2.1 & 0.4 & - & 94.1 & 5.9 & - & 3.2 & 1.6 & 0.1 & 3.2 \\
\hline
\end{tabular}

glauconite occurs mainly as grains, and also as infilling in some of the organic remains, for instance commonly in the cavities of the sponge spicules. The pyrite occurs as casually formed concretions, as fine grains in the matrix and as pigment in sponges and glauconite grains, but plays no great part in the building up of the rocks. Of organic components there are considerable quantities of sponge spicules, of the same type as always occurs in the Paleocene (straight or rayed). Usually they consist of amorphous silica, more rarely of chalcedony. Diatoms and radiolaria occur subordinately. The occurrence of foraminifera has already been referred to in the calcareous sample, but there also seem to be a few entirely silicified foraminifera in the non-calcareous samples. The matrix

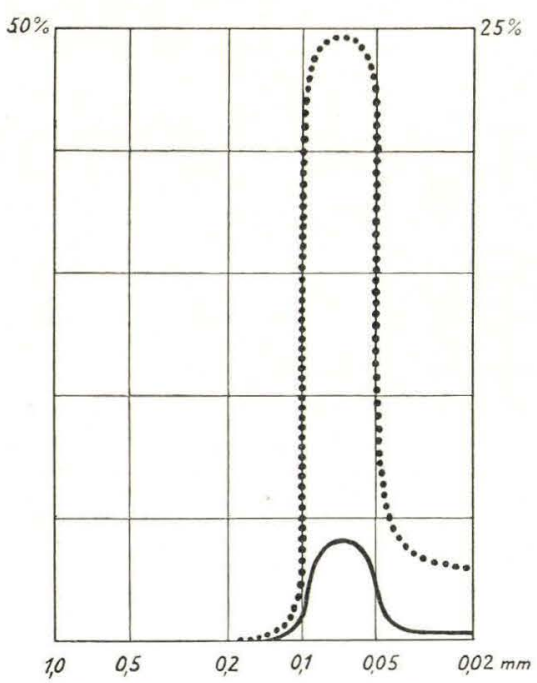

Fig. 28. Distribution curves, Rugaard.

- Glauconite; ...... Allochthonous sand (Quartz etc.). For further explanation see Fig. 11 page 53. is brownish and finely granulated, and is completely impregnated by amorphous silica. It contains numerous small particles of minerals and organisms.

From the description it will be seen that the consolidated rocks are of exactly the same type as the unconsolidated rocks, except that they are silicified in a manner similar to the other silicified Paleocene rocks.

The non-calcareous rocks at $\mathrm{Ru}$ gaard, whose position in the Tertiary series appears neither from the fossil content nor from the stratigraphical position at this locality, reveal themselves to be typical Paleocene by their mineral content, their wealth of 
sponge spicules and their silicification. At Rugaard, then, we have Paleocene rocks that are almost free of calcium carbonate, are glauconitic, and contain an abundance of allochthonous sandy components. These three features, which are characteristic of Rugaard's "non-calcareous" facies, recur at several places in the upper parts of the Paleocene series in the boring sections (see next chapter), and therefore must be described as characteristic of the upper parts of the Paleocene in Denmark.

\section{Borings.}

As most of the borings taken for examination in this work were rope borings or wash borings, the sample material available is usually rather poor. In most cases the samples consist of small lumps of rock or of a thoroughly kneaded mass; and, as a result of the boring method employed, the rocks from various depths have often been mixed together. In addition, the taking of the samples might have been better in many cases, and the samples sometimes are marked with one depth, sometimes with a depth interval. In the latter case it is impossible to know whether the sample came from the upper limit of the interval, its lower limit, or somewhere in between.

This being so, only little importance is attached in the following to establishing of exact boundaries for the different deposits, most stress being laid upon a demonstration of the variations in the rock character from stratum to stratum. These variations are clearest when presented in graphic form, for which reason I have drawn boring sections indicating the principal characters of the rocks.

The most important variable factors in the Paleocene rocks are: 1) sand content, 2) calcium carbonate content and 3) ratio of glauconite to pyrite.

1) Sand content. The components which make the rock more or less sandy are usually, in the lower parts of the series, the lime sand particles much more than anything else. In the lower samples glauconite grains also form a considerable part as a rule, whereas quartz sand has never been found definitely in any large quantity. In the lower samples there seems to be an appreciable quantity of quartz sand only in those that are very impure and mixed, so that it has come from the Quaternary. In samples from the upper parts of the Paleocene series there is never any lime sand of importance, and most of the sand grains as a rule are quartz and glauconite (cf. Rugaard). 
It is difficult to make an appraisal of the sand content, partly because the rock samples may be mixed with sandy material from the Quaternary, partly because of the presence of fine dust of silicified rocks with their content of silicified sponge spicules. For that reason in most of the boring sections a distinction has been made between three degrees of sand content, and, as far as is practicable, the rocks are divided into three groups: sandy rocks, corresponding in consistency with the greensand in Copenhagen and Lellinge, slightly sandy rocks, containing only finer sandy particles but also a very large proportion of mud, and clayey rocks, which contain almost no sand grains (like the Kerteminde marl).

2) Calcium carbonate content. The variations here are connected with the quantity of anchi-autochthonous lime sand and calcareous mud, which are of importance mostly in the lower parts of the series, and with the content of calcareous organisms (coccoliths, foraminifera) and chemically precipitated calcareous mud (mostly in the Kerteminde marl). In addition, there are the variations due to the silicification of the rocks. The fact is that the silicified rocks always contain much less calcium carbonate than the unconsolidated rocks, and therefore an intermixture of fine dust of silicified rock will assert itself in the calcium carbonate content - in certain cases to a very pronounced degree. Naturally this must be taken into consideration when interpreting the variations from stratum to stratum.

3) The ratio of glauconite to pyrite. The glauconite-pyrite ratio, which has a bearing upon our understanding of the chemical and physical conditions under which the rocks were formed, has been calculated among particles of a size about $0.05 \mathrm{~mm}$, this size occurring both in the most sandy and in the most clayey samples.

From the counts made in the rocks from exposed localities we see that the glauconite-pyrite ratio may vary from grain size to grain size, usually in such a manner that the coarsest fractions have a preponderance of one of these minerals, whereas among the finer grains there is a lessmarked preponderance of the leading mineral. The effect of this circumstance, combined with the possible mixing together of material from glauconitic and pyritic strata, is that the extreme glauconitic or pyritic character is not always so distinct in the boring material; on the other hand, however, we may attach so much the greater importance to the variations which nevertheless appear in the series.

The boring sections are so drawn that the boring is indicated by a column which is to be taken as a coordinate system, in which the ordinate represents the place of the sample in the boring, while the abscissa is the calcium carbonate content and the glauconite content calculated from 
glauconite + pyrite. The sand content is shown by a more or less dense stippling.

The depth at which the sample was taken is indicated by a transversal line which is continuous if the sample is marked with a single depth, broken if it came from an interval. In the latter case the depth at the middle of the interval is given.

The variation of the calcium carbonate content is indicated by a broken curve. The distance from the left side of the column marks the percentage of calcium carbonate, so that it is 0 if the curve runs on the left side of the column, 100 if it runs on the right side. Similarly, the glauconite percentage is marked by a continuous curve. It must be borne in mind that the distance from the left to the curve indicates the glauconite percentage, whereas the distance from the right to the curve gives the pyrite percentage.

The greater part of the borings have already been published, but a fresh examination of the samples has been necessary in order to determine the glauconite-pyrite ratio. - Enclosed in an angular bracket is the serial number of the boring in the Boring Archives of Denmark's Geological Survey. If the samples belong to the Mineralogical Museum and are kept there, the Museum number of the boring is also given in curved brackets.

All depths originally recorded in feet have been converted to metres to one decimal.

Maarum [187.28] (Hilmar ØDum 1932).

At this isolated occurrence of the Paleocene, situated in the forest Gribskov in North Sealand, there is:

0-104 m. Quaternary.

104-116 m. Brownish-black, slightly sandy clay and grey greensand.

116-124 m. Greensand limestone.

In all essentials the rocks are identical with those at Copenhagen, and there seems to be a similar transition from a sandy facies at the bottom to a clayey facies at the top. The calcium carbonate and glauconite contents were: brownish-black, slightly sandy clay: calcium carbonate $7.0 \%$, glauconite $7 \%$; grey greensand: calcium carbonate $36.3 \%$, glauconite $82 \%$; greensand limestone: calcium carbonate $58.5 \%$, glauconite $89 \%$. Pyrite occurs for the greater part in the form of spheres and diatom infillings.

The boring at Maarum is of particular interest, for it reveals the same rocks as the localities in Copenhagen and the same transition from sandy, calcareous, glauconitic rocks at the bottom to clayey, pyritic rocks with a low calcium carbonate content at the top. There is a difference between the pyritic rocks in these localities and those in the localities farther west, as there they are almost always of very pale grey marls. 
Odden [184.1] and [184.3].

The boundary between Danium and Paleocene has been found in two borings at Odden Dairy, Sjællands Odde. The samples are:

Boring 184.1.

0-56.3 m. Quaternary.

56.3-57.4 m. Light grey greensand limestone.

57.4-65.6 m. Saltholm limestone (hardened lime-sand) and pale flint (Danian).

Boring 184.3.

0-49.5 m. Quaternary.

49.5-57.5 m. Mixture of Quaternary, greensand limestone and pale flint.

57.5-64.5 m. Saltholm limestone (hardened lime-sand) and pale flint (Danian).

The substratum to the Paleocene is a limestone of a type similar to that forming the substratum at Copenhagen, i. e. a limestone built up of clastic calcareous grains of organic origin.

The greensand limestone is of exactly the same type as that at Copenhagen but somewhat lighter in colour. The calcium carbonate content is $87.3 \%$. Thin sections reveal the same structure as the rocks at Copenhagen, with a little pigmentary glauconite in the lime particles, but mostly glauconite in the form of grains. Pyrite forms only 4 to $5 \%$ of the total glauconite + pyrite.

Roskilde [206.2] (B. 4. 20) (O. B. BøGGILD 1918 p. 116).

Almost all the samples are greatly mixed with Quaternary material.

$55.2-55.9 \mathrm{~m}$. Rather pale grey, clayey greensand, partly silicified. Calcium carbonate $36.6 \%$, glauconite $53 \%$.

71.6-72.2 m. Like the overlying rock but a little darker. Calcium carbonate $29.5 \%$, glauconite $47 \%$.

74.1-75.3 m. Incoherent greensand, very impure. Calcium carbonate $32.1 \%$, glauconite $58 \%$.

77.2-77.8 m. Incoherent greensand. Calcium carbonate $72.4 \%$, glauconite $68 \%$. $77.8-78.5 \mathrm{~m}$. Incoherent greensand. Calcium carbonate $59.3 \%$, glauconite $63 \%$.

78.5-79.1 m. Incoherent greensand, darker and more clayey, perhaps owing to impurities. Calcium carbonate $54.8 \%$, glauconite $65 \%$.

79.7-80.4 m. Incoherent greensand. Calcium carbonate $70.7 \%$, glauconite $62 \%$. 86.6-87.3 m. Incoherent greensand. Calcium carbonate $64.8 \%$, glauconite $71 \%$. 87.3-87.9 m. Incoherent greensand. Calcium carbonate $75.2 \%$, glauconite $60 \%$. 87.9-88.2 m. Mixture of greensand and incoherent bryozoan limestone.

88.2-91.2 m. Incoherent bryozoan limestone and pale flint.

The lower boundary of the Paleocene must lie at $88 \mathrm{~m}$. Overlying the bryozoan limestone is $33 \mathrm{~m}$ of greensand of the usual lime sand - glauconite facies. The quantity of sand, the calcium carbonate content and the glauconite content decrease gradually upwards in the section. (Fig. 30 p. 137). 
Holbæk [198.19] (V. Milthers 1907, O. B. BøgGLLD 1918 p. 119).

$0-56.5 \mathrm{~m}$. Quaternary.

$56.5-72.2 \mathrm{~m}$. Light grey Kerteminde marl, unsilicified and with very few siliceous organisms. Numerous coccoliths and foraminifera. Calcium carbonate $67.3 \%$, glauconite $33 \%$.

$72.2-77.2 \mathrm{~m}$. Fine grey greensand, the sand particles mostly lime sand. Calcium carbonate $74.7 \%$, glauconite $77 \%$.

$78.5-82.5 \mathrm{~m}$. Fine greensand like that overlying it. Calcium carbonate $79.1 \%$, glauconite $79 \%$.

$82.5-83.2 \mathrm{~m}$. Fine greensand like that overlying it. Calcium carbonate $84 \%$, glauconite $90 \%$.

83.2-92.6 m. Similar, but slightly coarser. Calcium carbonate $64.2 \%$, glauconite $87 \%$.

A few slightly silicified fragments under the microscope reveal a rock exactly corresponding to the silicified samples from Lellinge, with the lime sand particles lying in a brownish matrix and with numerous needle-shaped sponge spicules transformed into chalcedony.

92.6-97.9 m. Greensand like that overlying it. Calcium carbonate $63.4 \%$, glauconite $98 \%$. The sample also contains a few darker, brownish grey pieces of a more clayey rock with calcium carbonate $36 \%$ and glauconite $64 \%$.

97.9-100.1 m. The sample contains mainly a rather hard, whitish-grey limestone, which under the microscope proved to consist of lime sand particles lying in a calcite cement. Some of the lime grains are glauconitized, and there are also some few grains of glauconite. The sample exhibits the same cementation as the Lellinge greensand limestone, there being numerous casts of needle-shaped sponge spicules, secondarily infilled with clear calcite cement. Calcium carbonate $92.5 \%$.

100.1-102.6 m. Lime-sand of pale, whitish-grey colour. The residue after treating with dilute hydrochloric acid contains a number of small quartz grains up to $0.1 \mathrm{~mm}$ and a quantity of glauconite, some having been shaped after sponge spicules. Calcium carbonate $56.8 \%$, glauconite $89 \%$.

The sample also contains some rather dark flint, transparent and presumably Cretaceous, as such flint otherwise is not known in the Paleocene. The lime-sand, which as O. B. BøGGILD states contains some opal (as do some of the overlying samples), is evidently Paleocene, but the flint indicates that the boring has stopped in the Danian.

The Paleocene section shows that the lower deposits are characterized by lime sand and glauconite. The quantity of sandy particles decreases upwards in the section and simultaneously the quantity of pyrite increases, so that the upper strata at Holbæk are pyritic marl (Fig. 30 page 137). The occurrence of a dark clayey deposit near the bottom of the section shows that there is a certain degree of facies alternation. Possibly this dark rock is comparable with the dark marl at Lellinge. 
Stedstrup [205.1].

In this boring, which is situated $5 \mathrm{~km}$. south of Tølløse Station in Sealand, the boring journal states there is Paleocene from 91.0 to $152.9 \mathrm{~m}$. The Paleocene has not been bored through. The samples reveal.

96.0 m. Light grey Kerteminde marl. Calcium carbonate $58.5 \%$, glauconite $23 \%$.

$96.7 \mathrm{~m}$. Very coarse grey-green greensand-stone. Calcium carbonate 1,3\%, glauconite $93 \%$.

$97.3 \mathrm{~m}$. Light grey, slightly sandy marl. Calcium carbonate $46.8 \%$, glauconite $71 \%$.

98.9 m. Light grey marl. Calcium carbonate $52.2 \%$, glauconite $49 \%$.

$128.7 \mathrm{~m}$. Light grey marl. Calcium carbonate $71.5 \%$, glauconite $47 \%$.

The light grey marls are built up exactly as the normal Kerteminde marl, the only difference being their content of glauconite.

The thickness of the Paleocene is over $62 \mathrm{~m}$. The lower part of the series is not recorded, but all borings in the district show that there is greensand immediately overlying the Cretaceous. The few samples available from Stedstrup show that there is a distinct facies alternation between sandy, glauconitic rocks and more pyritic marls, which approach the typical Kerteminde marl in composition (Fig. 31 page 138).

Osted, 11 km SW of Roskilde [206.64] (Sigurd Hansen 1930, p. 17).

51-75 m. Light grey Kerteminde marl. Calcium carbonate 59,5\%, glauconite $23 \%$.

75-84 m. Greensand and greensand-stone. Calcium carbonate 68,3\%, glauconite $68 \%$.

This boring was made in a district where other borings reveal that there is up to $45 \mathrm{~m}$ greensand over the Cretaceous. The boring shows the same superposition of Kerteminde marl over greensand as was found at Holbæk.

$$
\text { Ringsted. }
$$

At Ringsted there are several borings going down into the Paleocene. The best samples are from the following two borings:

Ringsted I [211.6] (C. 3. 2.) (O. B. BøGGLD 1918 p. 117).

$81.4 \mathrm{~m}$. Light grey Kerteminde marl. Calcium carbonate $80.3 \%$, glauconite $14 \%$.

85.4 m. Light grey Kerteminde marl. Calcium carbonate $85.6 \%$, glauconite $9 \%$.

$86.1 \mathrm{~m}$. Light grey Kerteminde marl. Calcium carbonate $85.3 \%$, glauconite $4 \%$.

$87.9 \mathrm{~m}$. Light grey Kerteminde marl. Calcium carbonate $81.0 \%$, glauconite $0 \%$. 
96.0 m. Light grey Kerteminde marl. Calcium carbonate $77.6 \%$, glauconite $2 \%$.

97.9 m. Light grey Kerteminde marl. Calcium carbonate $72.7 \%$, glauconite $10 \%$.

98.9 m. Light grey Kerteminde marl. Calcium carbonate $67.7 \%$.

$99.2 \mathrm{~m}$. Impure sample of Kerteminde marl. Calcium carbonate $44.7 \%$.

$99.5 \mathrm{~m}$. Kerteminde marl, rather sandy. Calcium carbonate $51.3 \%$, glauconite $26 \%$.

$99.8 \mathrm{~m}$. Light grey, slightly sandy marl, faintly silicified; some of the sandy particles are lime grains. Calcium carbonate $38.6 \%$, glauconite $42 \%$.

$100.4 \mathrm{~m}$. Light grey sandy marl, not silicified. The sandy particles mostly calcite and quartz. Calcium carbonate $49.6 \%$, glauconite $73 \%$.

$100.6 \mathrm{~m}$. Greensand-stone of the same type as at Lellinge. Calcium carbonate $40.0 \%$. The sample also contains stones which presumably have fallen down from the overlying Quaternary.

$101.1 \mathrm{~m}$. Dark grey marl, almost non-sandy. Calcium carbonate $47.2 \%$, glauconite $35 \%$.

101.7 m. Light grey, slightly sandy marl. Calcium carbonate $49.8 \%$, glauconite $66 \%$.

$102.3 \mathrm{~m}$. Light grey, slightly sandy marl. Calcium carbonate $53.3 \%$.

$102.9 \mathrm{~m}$. Light grey, slightly sandy marl. Calcium carbonate $53.0 \%$, glauconite $66 \%$.

$103.6 \mathrm{~m}$. Danian flint, presumably fallen down.

It is difficult to decide whether the flint and the stones in the bottom of the boring have fallen down or there are Quaternary deposits at these depths, so that the Paleocene would be a dislocated block. The fragment of the Paleocene series found in this boring reveals a passage from sandy glauconitic rocks at the bottom to typical Kerteminde marl at the top, but the coarsest rocks are a little way up the series.

\section{Ringsted II [211.17] (Ringsted Waterworks).}

33.0-39.9 m. Pure fragments of light grey greensand-stone, slightly silicified. Calcium carbonate $48.1 \%$, glauconite $82 \%$.

39.9-69.4 m. Pale, white-grey Kerteminde marl. Calcium carbonate $71.5 \%$, glauconite $8 \%$.

69.4-83.2 m. Pure fragments of light grey sandy marl. Much the greater part of the sand particles are calcareous grains. Calcium carbonate $66.3 \%$, glauconite $34 \%$.

This boring displays a very distinct facies alternation between glauconitic, sandy rocks and pyritic Kerteminde marl. (Fig. 31 page 138).

Another boring at the waterworks has been described by O. B. BøGGILD (1918 p. 117), who states that there is greensand limestone, fairly homogenous in appearance, in about the same depth interval, but we have no samples from this boring between 33 and 69 metres.

How the strata in the borings at Ringsted are to be combined is uncertain, but it is indisputable that there is a facies alternation between greensand deposits and Kerteminde marl. 
Sorø [210.47].

$0-79.0 \mathrm{~m}$. Quaternary.

$79.0-84.0 \mathrm{~m}$. Rather greasy, dark clay with typical Paleocene mineral content (sponge spicules, pyrite in the form of diatoms and small spheres). Calcium carbonate $4.8 \%$, glauconite $18 \%$.

$84.0-91.0 \mathrm{~m}$. Greensand-stone, partly silicified. Calcium carbonate $4.0 \%$, glauconite $84 \%$.

91.0-138.5 m. Light grey Kerteminde marl which, in addition to the usual minerals, contains some siderite in the form of concretions and rhombohedrons. Calcium carbonate $59.5 \%$, glauconite $37 \%$.

138.5-173.0 m. The boring journal records Kerteminde marl with hard layers of greensand-stone. These hard layers are $30 \mathrm{~cm}$. thick at the most. The sample contains only small fragments of greensandstone containing no particularly great number of lime sand particles. Calcium carbonate $37.5 \%$, glauconite $50 \%$.

$227 \mathrm{~m}$. Several samples, some of which apparently washed. An unwashed sample consists of fine dust of Kerteminde marl with harder, slightly sandy fragments. The boring journal records very hard greensand limestone from 227 to $235 \mathrm{~m}$, so the finer material has presumably fallen down. The pure fragments of greensand-stone are somewhat finer than the rock at overlying levels. Calcium carbonate $5.5 \%$, glauconite $76 \%$.

This boring shows that in Mid-Sealand the Paleocene is very thick (more than 156 metres) and that there is a considerable facies alternation between sandy, glauconitic and clayey, more pyritic strata (Fig. 31 p. 138). The exact distribution of the rocks and their thickness cannot be decided owing to the paucity of samples.

Christiansdals Kloster [216.1] (C. 3. 3.) (O. B. BøGGILd 1918 p. 117).

From this boring, which is situated $10 \mathrm{~km}$ SE of Sorø, there are the following samples from the Paleocene:

$67.5 \mathrm{~m}$. Rather incoherent greensand-stone, in which most of the sand particles are quartz. Calcium carbonate $6.4 \%$, glauconite $92 \%$.

$97.3 \mathrm{~m}$. Incoherent greensand-stone. The sample contains a number of round concretions and rhombohedrons of siderite. Calcium carbonate $26.2 \%$, glauconite $65 \%$.

$111.7 \mathrm{~m}$. Greensand-stone as above. Calcium carbonate $41.8 \%$, glauconite $61 \%$.

As far as can be judged from the few samples, the glauconitic sandy facies here is at least $44 \mathrm{~m}$ thick.

Slagelse [210.11] (D. 3. 5.) (O. B. BøGGILD 1918 p. 118).

49.3-60.9 m. Rather impure sample of grey Kerteminde marl, partly silicified. Calcium carbonate $42.5 \%$, glauconite $12 \%$.

$60.9-64.0 \mathrm{~m}$. As above. Calcium carbonate $39.7 \%$, glauconite $16 \%$.

down to $125.5 \mathrm{~m}$. Grey Kerteminde marl, pure sample. Calcium carbonate $54.6 \%$, glauconite $2 \%$. 
125.5-126.8 m. Fine rock dust consisting of a mixture of Kerteminde marl and chalk lumps. The minerals in the acid-treated sample are typical Kerteminde marl minerals with glauconite $1 \%$. After washing the original sample there is a residue containing i. a. pure, slightly consolidated fragments of a rather coarse limestone and a few bryozoa and foraminifera.

129.9-133.7 m. Incoherent, very fine-grained limestone resembling White chalk. The calcareous mud contains rather numerous coccoliths. Coarser lime particles are present, apparently bryozoan remains and foraminifera for the most part.

The boundary between the Cretaceous and the Paleocene must evidently lie at $126 \mathrm{~m}$. The occurrence of rather hard limestone fragments and coarse calcareous particles in the underlying samples indicates that the Cretaceous substratum consists of Danian coccolith chalk, though the consistency greatly resembles Senonian White chalk. From the very bottom the Paleocene has developed as typical Kerteminde marl with silicified layers in it. All the rocks are pronouncedly pyritic (Fig. 30 page 137). The thickness of the Kerteminde marl here is at least $77 \mathrm{~m}$.

Hulby, near Korsør [214.76].

From the Korsør district O. B. BøGGLD has a boring (Taarnborg Brickworks) showing that there is Paleocene, non-sandy marl directly over the Cretaceous, with a thickness of at least $42 \mathrm{~m}$. A later boring (Hulby), not previously published, gives the same showing, but the thickness is more than $100 \mathrm{~m}$.

All the Paleocene samples are typical, light-grey Kerteminde marl, with pyrite in small spheres and in the form of diatoms. Usually the samples contain some sponge spicules. At some depths the rocks are partly silicified.

$40.9 \mathrm{~m}$. Light grey Kerteminde marl, slightly sandy. Calcium carbonate $45.8 \%$, glauconite $59 \%$.

$50.0 \mathrm{~m}$. Light grey, soft Kerteminde marl. Calcium carbonate $66.3 \%$, glauconite $18 \%$.

$60.0 \mathrm{~m}$. Light grey, soft Kerteminde marl. Calcium carbonate $68.2 \%$, glauconite $4 \%$.

70.0 m. Light grey, soft Kerteminde marl. Calcium carbonate $75.1 \%$, glauconite $3 \%$.

$81.0 \mathrm{~m}$. Kerteminde marl with some slightly silicified fragments. Calcium carbonate $50.0 \%$, glauconite $19 \%$.

$85.0 \mathrm{~m}$. Mostly faintly silicified, light fragments. Calcium carbonate $44.3 \%$, glauconite $28 \%$.

$90.0 \mathrm{~m}$. Mixture of faintly silicified fragments and incoherent Kerteminde marl. Calcium carbonate $47.0 \%$, glauconite $40 \%$.

$100.0 \mathrm{~m}$. Kerteminde marl and some fine dust of silicified rock. Calcium carbonate $49.8 \%$, glauconite $17 \%$. 
$110.0 \mathrm{~m}$. Kerteminde marl. Calcium carbonate $42.5 \%$, glauconite $1 \%$.

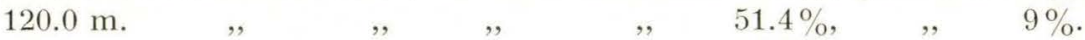

$130.0 \mathrm{~m} . \quad \quad, \quad, \quad, \quad, \quad \quad, \quad, \quad 53.5 \%, \quad, \quad, \quad 9 \%$.

$140.0 \mathrm{~m}$. Kerteminde marl and some hard fragments. Calcium carbonate $57.2 \%$, glauconite $5 \%$.

$143.8 \mathrm{~m}$. Kerteminde marl and some hard fragments. Calcium carbonate $58.0 \%$, glauconite $5 \%$.

$145.0 \mathrm{~m}$. Kerteminde marl and some hard fragments. Calcium carbonate $57.5 \%$, glauconite $17 \%$.

$150.0 \mathrm{~m}$. Mixture of Kerteminde marl, bryozoan limestone and flint.

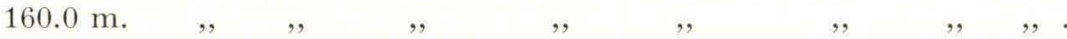

Overlying the Cretaceous there is here a series of Kerteminde marl at least $104 \mathrm{~m}$ thick. The glauconite-pyrite ratio shows that the rock is mainly pyritic, but at two levels there are larger quantities of glauconite (Fig. 30 page 137). The samples richest in glauconite are also somewhat silicified, and they seem to be a little more sandy than the others, but still typical marl.

Bjørnskilde Dairy [214.3] (D. 3. 16) (O. B. BøGGLL 1918 p. 118).

0-30.8 m. Quaternary, which from 20-28 $\mathrm{m}$ depth contains reddish Plastic clay.

32.3-38.3 m. Dark grey, sandy clay, mostly silicified. Calcium carbonate 0\%, glauconite $93 \%$.

38.3-41.4 m. As above. Calcium carbonate $11.5 \%$, glauconite $91 \%$.

$47.1 \mathrm{~m}$. Light grey Kerteminde marl. Calcium carbonate $60.8 \%$, glauconite $39 \%$.

This boring is a good $4 \mathrm{~km}$ northwest of the foregoing boring, and there does not seem to be any great difference in the levels between the two places where the borings were made. Judging by the depths and the rock characters the rocks at Bjørnskilde Dairy form the upward continuation of the Hulby series (Fig. 30 page 137). The upper part of the Hulby series tells that the rocks become a little more sandy upwards, poorer in calcium carbonate and richer in glauconite. At Bjørnskilde we see the same conditions, but there is a transition to a non-calcareous, sandy, pronouncedly glauconitic facies.

Ulriksholm [137.14] (E. 3. 22) (O. B. BøgGILD 1918 p. 120).

$31.4 \mathrm{~m}$. Grey non-calcareous clay, rather sandy, partly silicified. Mineral content: the usual Paleocene, with abundance of sponge spicules. Calcium carbonate $0 \%$, glauconite $80 \%$.

$32.0-33.3 \mathrm{~m}$. As above. Calcium carbonate $0 \%$, glauconite $89 \%$.

34.5-35.2 m. Like the above, but fewer sand particles. Calcium carbonate $0 \%$, glauconite $82 \%$.

$36.4 \mathrm{~m}$. Grey marl, not silicified. Calcium carbonate $13.1 \%$, glauconite $58 \%$. 
51.5-52.1 m. Light grey Kerteminde marl, not silicified. Calcium carbonate $52.5 \%$, glauconite $6 \%$.

$54.0-55.9 \mathrm{~m}$. As above. Calcium carbonate $50.2 \%$, glauconite $2 \%$.

$70.3 \mathrm{~m}$. As above. Calcium carbonate $48.3 \%$, glauconite $2 \%$.

$81.6 \mathrm{~m}$. As above. Calcium carbonate $59.5 \%$, glauconite $5 \%$.

87.6-92.3 m. Incoherent bryozoan limestone.

In this locality, which is situated about $6 \mathrm{~km}$ WSW of Kerteminde, the Cretaceous is overlain by a light-coloured and quite unsilicified marl, typical Kerteminde marl, almost devoid of glauconite and with a fairly uniform content of calcium carbonate (Fig. 29 page 136). Upwards the Kerteminde marl passes into darker, more sandy, non-calcareous clay, and simultaneously the glauconite content increases steadily, so that the upper samples are distinctly glauconitic. Accordingly, conditions at Ulriksholm are quite similar to those at Korsør, except that the thickness of the Kerteminde marl is much less, about $50 \mathrm{~m}$.

Dalum, near Odense [146.1] (E. 3. 71) (O. B. BøGGILD 1918 p. 120).

At Dalum O. B. BøGGILD describes two borings, one dated 1876-77 and one 1895-96. The best samples came from the 1876-77 boring.

49.6-51.8 m. Grey, slightly sandy marl partly silicified. Calcium carbonate $12.6 \%$, glauconite $82 \%$.

$59.0-64.0 \mathrm{~m}$. Light grey Kerteminde marl. Calcium carbonate $51.6 \%$, glauconite $6 \%$.

64.0-65.9 m. Light grey Kerteminde marl partly silicified. Calcium carbonate $32.2 \%$, glauconite $73 \%$.

$72.2-75.3 \mathrm{~m}$. Light grey, fine sandy marl, the sand particles mostly calcareous shell fragments. Calcium carbonate $78.5 \%$, glauconite $92 \%$.

75.3-77.5 m. Incoherent bryozoan limestone and pale flint.

The lowest Paleocene sample here is influenced by the fact that the substratum is a coarse calcareous rock, but the Paleocene quickly passes into a fine-grained marl (Fig. 29 page 136). The low content of calcium carbonate in the sample from $64.0-65.9 \mathrm{~m}$ undoubtedly is connected with the silicification. Taken on the whole there is thus a decreasing calcium carbonate content upwards in the section. The lower Paleocene strata are glauconitic, over them is normal pyritic Kerteminde marl, and uppermost are rocks that are less rich in calcium carbonate and richer in glauconite. It is evident that typical Kerteminde marl is not so predominant here as in the localities described more to the east.

Sværup, near Langesø [136.3] (F. 3. 19) (O. B. BøGGLd 1918 p. 122).

$44.3 \mathrm{~m}$. Impure sample of grey, non-calcareous clay with a few pure, slightly silicified lumps which are rather sandy. Mineral content typically Paleocene, with some sponge spicules. Calcium carbonate $0 \%$, glauconite $77 \%$. 
$46.5 \mathrm{~m}$. Grey clay, partly silicified. Calcium carbonate $13.2 \%$, glauconite $67 \%$.

72.2-75.3 m. Light grey Kerteminde marl. Calcium carbonate $45.4 \%$, glauconite $26 \%$.

84.7-85.4 m. Mostly grey, silicified lumps with numerous sponge spicules. Calcium carbonate $40.7 \%$, glauconite $59 \%$.

94.2-95.4 m. Light grey marl and rather few silicified fragments. Calcium carbonate $36.0 \%$, glauconite $47 \%$.

97.9-98.6 m. Grey marl and hard silicified fragments. Calcium carbonate $29.3 \%$, glauconite $62 \%$.

$101.7 \mathrm{~m}$. Grey marl and silicified fragments. Calcium carbonate $36.4 \%$, glauconite $68 \%$.

The fragment of the Paleocene series found at Sværup reveals the transition from marl to non-calcareous facies. The marl is not extremely pyritic like typical Kerteminde marl, but contains both glauconite and pyrite. The pyrite maximum is in the middle of the series, where the rock is lightest in colour and least silicified. Upwards the marl passes into less calcareous, slightly sandy and glauconitic rocks and uppermost becomes free of calcium carbonate. The transition from calcareous to non-calcareous facies thus displays conditions similar to those at Ulriksholm and Korsør.

Wedellsborg [144.1] (G. 3. 1) (O. B. BøGGILD 1918 p. 95).

This boring goes through Plastic clay, tuff-bearing series and Paleocene. The following samples were yielded by the lower part of the boring:

100.4-103.6 m. Volcanic tuff.

103.6-108.3 m. Dark grey clay with volcanic tuff. Glauconite $24 \%$.

108.3-116.1 m. Pure rock fragments of various clays, mostly brownish Plastic clay, subordinately dark-grey clay and volcanic tuff, all completely or almost non-calcareous.

116.1-124.9 m. Same combination as from the foregoing depth. The glauconitepyrite ratio has been counted on a casual mixture of these rocks. Glauconite: $53 \%$.

124.9-128.7 m. Grey Paleocene clay with rather few sandy particles. Calcium carbonate $14.9 \%$, glauconite $80 \%$.

128.7-135.0 m. Grey clay as above. Calcium carbonate $15 \%$, glauconite $74 \%$. $135.0-141.2 \mathrm{~m}$. The same. Calcium carbonate $12.1 \%$, glauconite $75 \%$.

141.2-149.1 m. The same. Calcium carbonate $10.0 \%$, glauconite $88 \%$.

149.1-153.8 m. Bryozoan limestone.

The rocks from $108.3-124.9 \mathrm{~m}$ cannot have fallen down, as no similar rocks occur in the overlying samples. The rocks from these depths being typical Plastic clay (Eocene) and partly grey clay with tuff, the Paleocene can only begin at about $125 \mathrm{~m}$.

The full thickness of the Paleocene here is about $24 \mathrm{~m}$, and the rocks are fairly uniformly developed throughout the series, viz. slightly cal- 
careous, glauconitic grey clay (Fig. 32 page 139). The glauconite content, which is high all through the Paleocene, falls as we get into the Eocene rocks.

\section{Fredericia I [125.39] (G. 4. 147) (O. B. BøGGILD 1918 p. 93).}

This boring, made in 1873, runs through the Plastic clay down into the Paleocene. On the whole the samples are greatly mixed or kneaded, and as they all contain a greater or smaller quantity of finely powdered silicified rocks, it is difficult to decide whether some rocks are more sandy than others.

As O. B. BøGGILD states, there is a sample of Plastic clay at a depth of $110 \mathrm{~m}$, but under that no sample before the $147 \mathrm{~m}$ level. The following samples must belong to the Paleocene:

$147.2 \mathrm{~m}$. Grey clay. Calcium carbonate

$149.4 \mathrm{~m}$.

$151.9 \mathrm{~m}$.

$153.8 \mathrm{~m}$. Grey marl

$155.0 \mathrm{~m}$. Grey clay

$157.9 \mathrm{~m}$. Grey marl

$165.7 \mathrm{~m}$.

$167.6 \mathrm{~m}$.

$169.2 \mathrm{~m}$.

$169.5 \mathrm{~m}$.

$170.1 \mathrm{~m}$.

$171.1 \mathrm{~m}$.

$171.7 \mathrm{~m}$.

$172.0 \mathrm{~m}$.$$
\text { , }
$$

,

,,

,

,

,

,

,

,

,

,

,

,,

",
$0 \%$, glauconite $30 \%$.

$0 \%, \quad, \quad 50 \%$.

$0 \%, \quad, \quad, \quad 46 \%$.

$24.0 \%, \quad, \quad 57 \%$.

$2.4 \%, \quad, \quad 62 \%$.

$30.8 \%, \quad, \quad 66 \%$.

$33.1 \%, \quad$, $\quad 43 \%$.

$33.6 \%, \quad, \quad 42 \%$.

$12.5 \%, \quad, \quad 46 \%$.

$29.4 \%, \quad, \quad 51 \%$.

$13.6 \%, \quad, \quad 43 \%$.

$30.8 \%$, , $\quad 37 \%$.

$31.5 \%, \quad, \quad 40 \%$.

$17.0 \%, \quad, \quad 36 \%$.

$172.6 \mathrm{~m}$. More sandy rock with quartz, pyrite and glauconite. Calcium carbonate $12.8 \%$, glauconite $18 \%$. There is also a core from the same depth, consisting of a light grey silicified marl.

In a mineralogical sense there is no difference between the calcareous and the non-calcareous rocks. As a rule there are no coarse sand particles; only in the lowest samples are there grains of $0.1-0.2 \mathrm{~mm}$. Sponge spicules are frequent in all the samples and the pyrite occurs mostly in the form of small spheres and as diatoms. To a great extent the very varying calcium carbonate content seems to be connected with a varying intermixture of silicified rock. The glauconite-pyrite ratio oscillates rather unevenly, and there is no pronounced preponderance of either of these chemically formed minerals.

Fredericia II [125.40] (G. 4. 148) (O. B. BøaGILD 1918 p. 93).

This boring, which was made in $\mathbf{1 8 7 5}$, was made with a core drill, so that the rock samples are quite pure. Unfortunately, sampling was faulty in the upper parts of the series. 
According to O. B. BogGILD, the journal states that Plastic clay was found down to $130 \mathrm{~m}$, but he found tuff in a sample from $113 \mathrm{~m}$. Of Paleocene samples there are the following:

131.2-172.3 m. Light grey marl. Calcium carbonate $11.2 \%$, glauconite $67 \%$. 172.0-172.3 m. Light grey silicified marl. Calcium carbonate $12.7 \%$, glauconite $30 \%$.

172.6 m. Light grey unsilicified marl. Calcium carbonate $65.3 \%$, glauconite $34 \%$. The sample also contains chert.

$175.8 \mathrm{~m}$. Chert.

176.4-176.7 m. Light grey unsilicified marl. Calcium carbonate $79.8 \%$, glauconite $29 \%$.

177.0-178.3 m. Light grey unsilicified marl. Calcium carbonate $70.0 \%$, glauconite $15 \%$.

180.2 m. Light grey unsilicified marl. Calcium carbonate $63.8 \%$, glauconite $20 \%$.

182.0-182.4 m. Light grey unsilicified marl. Calcium carbonate $69.0 \%$, glauconite $5 \%$.

182.4-183.3 m. Chert.

183.3-184.9 m. Light grey unsilicified marl. Calcium carbonate $83.5 \%$, glauconite $22 \%$. The sample also contains chert.

According to earlier descriptions the rocks from $172.6 \mathrm{~m}$ downwards are limestone from the Danian. A more exact petrographical examination shows, however, that it is all Paleocene marl, corresponding in character to the Kerteminde marl but on the whole richer in glauconite. The calcium carbonate in the samples is mostly in fine grains, but there are also some coccoliths and foraminifera. There are small quartz splinters in all samples and needle-shaped sponge spicules in most. The pyrite is in the form of small spheres and as diatoms.

The silicified samples display the same transformations as in the marl outcrops, but silicification has often reached a more advanced stage. A thin section of a sample from $183.3-184.9 \mathrm{~m}$ reveals numerous needleshaped sponge spicules enclosed in a brownish, single-refracting silicified matrix. The matrix contains many foraminifera in which the calcium carbonate has disappeared, and a number of small pyrite concretions, some of which are agglomerations of small spheres. By their triangular form a few concretions reveal that they were formed in diatoms.

If this boring is compared with the foregoing one, it will be observed that there is some disagreement with regard to the content of calcium carbonate in the samples from similar depths, in spite of the fact that both borings were made at the same place. The differences are explainable, however, by lack of uniformity in sampling and by the character of the samples. The uppermost sample from Boring II is marked with a very large depth-interval, but conditions in Boring I make it probable that the sample came from the lower part of that interval, viz. from the boundary between the non-calcareous and the calcareous Paleocene. The 
high glauconite content supports that argument. The low calcium carbonate content of the next uppermost sample from Boring II is undoubtedly a result of silicification, as in the case of the most silicified samples from the same depth in Boring I.

If we combine conditions in the two borings we come to the result that to an overwhelming extent the Paleocene is present in the form of a marl facies, which, however, at a certain depth contains a more sandy stratum. On the whole the content of calcium carbonate is the lower the higher up the section we go, so that the uppermost samples are free of it. At the base of the series the rocks contain pyrite in particular, as in the Kerteminde marl outcrops, but as we go upwards we find increasing quantities of glauconite, so that the rocks mostly are intermediate with regard to glauconite and pyrite content.

Strib [125.48] (G. 4.62) (O. B. BøGGLLD 1918 p. 95).

This boring goes through Plastic clay and tuff-bearing deposits down into the Paleocene. The following samples come from the lower parts of the boring:

93.5-102.0 m. Volcanic tuff and greyish-black, greasy clay with transformed diatoms.

$119.0 \mathrm{~m}$. Paleocene grey clay, partly silicified. Calcium carbonate $3.6 \%$, glauconite $43 \%$.

124.9-125.2 m. As above, rather greasy. Calcium carbonate $7.1 \%$, glauconite $59 \%$.

140.3-140.6 m. As above. Calcium carbonate $1.6 \%$, glauconite $52 \%$.

$145.0-145.3 \mathrm{~m}$. Grey clay, partly silicified. Calcium carbonate $10.2 \%$, glauconite $39 \%$.

$149.1 \mathrm{~m}$. As above. Calcium carbonate $13.7 \%$, glauconite $53 \%$.

$149.7-150.0 \mathrm{~m}$. As above. Calcium carbonate $8.3 \%$, glauconite $42 \%$.

$151.0 \mathrm{~m}$. Grey clay, slightly sandy, partly silicified. Calcium carbonate $13 \%$, glauconite $27 \%$.

According to O. B. BøGGILD, the boring stopped at a depth of $152 \mathrm{~m}$ in the Cretaceous, but a comparison with conditions at Fredericia makes it probable that at Strib too the Paleocene goes much deeper. The rocks are similar to those at Fredericia, viz. marl with both glauconite and pyrite. The calcium carbonate content is rather low throughout the series, but decreasing upwards. As at Fredericia, there are no samples from the boundary between Paleocene and Eocene.

Besser in Samsø [109.1] (Gronwall 1907, O. B. Bøggild 1918 p. 122).

$0-37.0 \mathrm{~m}$. No samples.

$37.0-40.8 \mathrm{~m}$. Grey non-calcareous clay, glauconite $83 \%$.

40.8- 47.1 m. Grey non-calcareous clay. Contains rhombohedrons of siderite, glauconite $70 \%$. 
$50.2-64.0 \mathrm{~m}$. Grey non-calcareous clay. Glauconite $80 \%$.

$64.0-72.2 \mathrm{~m} . \quad$, $\quad$ ", $\quad, \quad$, $\quad 57 \%$.

$72.2-79.1 \mathrm{~m} . \quad, \quad, \quad$ " $\quad$ ", $\quad, \quad 65 \%$.

$79.1-81.9 \mathrm{~m}$. Grey, rather greasy non-calcareous clay. Glauconite $55 \%$.

$81.9-84.7 \mathrm{~m}$. Grey non-calcareous clay. Glauconite $46 \%$.

$84.7-86.6 \mathrm{~m} . \quad, \quad$, $\quad, \quad$, $\quad, \quad 42 \%$.

$86.6-89.5 \mathrm{~m} . \quad, \quad, \quad \quad, \quad, \quad, \quad, \quad, \quad 20 \%$.

$89.5-93.8 \mathrm{~m} . \quad, \quad \quad \quad, \quad \quad, \quad, \quad, \quad 42 \%$.

93.8- $96.4 \mathrm{~m}$. Light grey marl. Calcium carbonate $38.9 \%$, glauconite $38 \%$.

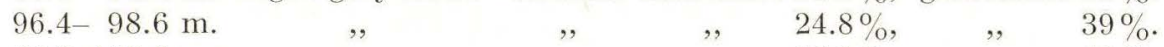

$\begin{array}{lllll}98.6-103.0 \mathrm{~m} . \quad & \text { " } & \text { " } & & \end{array}$

103.0-109.2 m. Grey sandy marl. $\quad, \quad, \quad$, $\quad 42.2 \%, \quad$, $\quad 43 \%$.

$109.2-110.5 \mathrm{~m} . \quad \quad, \quad$, $\quad$, $\quad, \quad 36.4 \%, \quad, \quad 36 \%$.

$110.5-113.0 \mathrm{~m} . \quad \quad$, $\quad, \quad, \quad, \quad 31.8 \%, \quad, \quad, \quad 36 \%$.

$113.0-113.3 \mathrm{~m} . \quad$, $\quad, \quad, \quad, \quad 44.8 \%, \quad, \quad, \quad 36 \%$.

$\begin{array}{lll}113.3-113.8 \mathrm{~m} . & \quad & \end{array}$

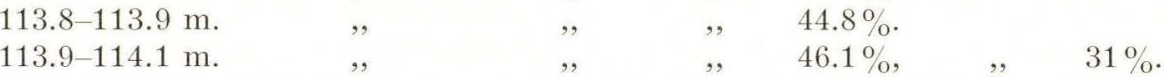

114.1-114.6 m. Mixture of grey sandy marl, light grey flint and pure whitishgrey lime-sand.

114.6-116.1 m. As above.

116.1-117.4 m. Pure whitish-grey lime-sand. Calcium carbonate $72.2 \%$, glauconite $0 \%$.

117.4-123.0 m. Pure whitish-grey lime-sand. Calcium carbonate $73.6 \%$, glauconite $0 \%$.

123.0-131.8 m. Pure whitish-grey lime-sand. Calcium carbonate $76.8 \%$, glauconite $0 \%$.

The following types are distinguishable among the rocks:

The grey non-calcareous clay is never very greasy, but contains a quantity of fine, sandy particles. Pyrite occurs partly in the form of diatoms; sponge spicules are common in most of the samples, even the uppermost.

The light grey marl is of the usual marl type, resembling Kerteminde marl, but containing more glauconite. The calcite occurs especially as fine grains in the mud and as coccoliths.

The grey sandy marl. The sandy particles are mostly impure lime grains, partly foraminifera, partly rounded lime sand grains of organic origin, as in the rocks at Copenhagen. Subordinately there are newlyformed calcite grains (rhombohedrons); glauconite and quartz grains are somewhat larger than in the overlying marl.

The lime-sand. Most of the particles in the lime-sand are impure, isodiametric lime grains of organic origin. Foraminifera are fairly frequent, bryozoan fragments more rare. Pure calcite crystals have often grown out from the original clastic lime grains. Newly formed calcite rhombohedrons without a core of a clastic lime grain are also present, but not particularly common. Most of the lime grains are about $0.1 \mathrm{~mm}$ in diameter. 
In thin sections of some consolidated rocks we have a picture very closely resembling the Danian lime-sand from Vodroffsvej, with the lime grains packed closely together. Pyrite is deposited here and there between the lime grains, whereas other minerals are extremely scarce. O. B. BøGGILD writes that the limestone is permeated with flint substance which in the acid-treated material often proves to have a regular foraminifera form. Most flinty particles, however, are very irregular in shape, which is connected with the fact that it is particularly the matrix between the particles that is silicified.

The flint. The samples that are most silicified appear in thin sections as calcareous flint formations of a character similar to the outer part of the flint in the lime-sand at Copenhagen. It is still possible to distinguish the lime grains with their original structure, but they lie in a matrix or cement consisting of chalcedony. Sponge spicules, which occur so frequently in the silicified rocks of the Paleocene, and from which the conversion to chalcedony starts, occur neither in the least nor in the most silicified samples of lime-sand.

GronwaLl places the deposits from $116.1 \mathrm{~m}$ to the Cretaceous, whereas BøagILD considers it is all Paleocene, as all the rocks in the lower part of the boring are permeated with chalcedony. It is very difficult to decide which is right, as the lime-sand formations from the Cretaceous and the lower greensand formations from the Paleocene often resemble each other to the point of confusion. One argument in favour of the Paleocene age of the deposits is the silica impregnation, but other features in the structure of the rocks and in the series lean towards the Cretaceous. I am inclined to think that the lime-sand is Cretaceous, for the following reasons:

1. In the series there is a distinct and abrupt change of colour from whitish to brownish rocks. Apparently the cause of this is the absence of terrigenous mud in the lower rocks.

2. There is a sudden change from sandy to less sandy rocks.

3. There is a sudden jump in the content of calcium carbonate.

4. There is a sudden jump in the glauconite content, this mineral only appearing over the boundary of the light-coloured lime-sand.

5. No trace has been found of sponge spicules in the lime-sand.

6. No pronouncedly sandy, lime sand - pyrite facies has otherwise been met with in the Paleocene.

As the samples from $114.1 \mathrm{~m}$ and downwards contain pure whitish lime-sand as an intermixture, I put the boundary of the Cretaceous at $114.1 \mathrm{~m}$.

The quantity of lime sand decreases upwards in the Paleocene section, so that the lower part of the series is sandy, the middle part marly and the upper part non-calcareous. The rocks are mostly intermediary types with 
regard to glauconite and pyrite content, but the lowest glauconite content is in the middle of the section, the highest in the top. (Fig. 29 page 136).

\section{A belt oft.}

At Ebeltoft there are two borings in which Paleocene has been found overlying the Cretaceous, one in the town, another $3 \mathrm{~km}$ more to the SW at the farm Ahlgaard.

Ab beltoft town [90.4] (E. 6. 8) (Hilmar ØDUM) 1926 p. 30).

0-36.0 m. Quaternary deposits.

36.0-39.0 m. Impure sample of light grey Kerteminde marl. Calcium carbonate $59.5 \%$. Pyrite present as spheres and diatoms, no glauconite.

39.0-40.75 m. Impure sample of dark grey, sandy marl. Calcium carbonate $60.4 \%$. The sandy residue is almost exclusively fairly large glauconite grains, subordinately lime grains. The sample also contains some few glauconitized Danian fossils.

40.75-42.0 m. Almost all hard limestone and pale flint. Also a little sandy material like the overlying sample.

Ahlgaard [90.5].

40-45 m. Dark sandy marl. Calcium carbonate $48.0 \%$. Of sandy components hardly anything but glauconite grains and lime sand grains.

No depth recorded. The same, as well as rolled and glauconitized Danian fossils, Danian flint, and limestone.

44-46.5 m. Compact limestone and flint.

These borings show that at Aibeltoft there are formations similar to those found at the outcrops at Hvalløse and Svejstrup. At the bottom is a marl facies with glauconite sand, though it passes quickly into typical Kerteminde marl (Fig. 29 page 136). The basal layer has apparently contained rolled glauconitized shells, and may be there has been a basal gravel like that at Copenhagen and Hvalløse.

Hornslet, $20 \mathrm{~km} \mathrm{NNE}$ of Aarhus [79.11].

30-31 m. Dark, slightly sandy clay. Calcium carbonate $12.5 \%$, glauconite $28 \%$.

31-34 m. Grey, sandy clay. Calcium carbonate $1.3 \%$, glauconite $57 \%$. The sample also contains rolled, glauconitized Danian fossils, coccolith chalk and Danian flint.

34-35 m. Fine sandy coccolith chalk and flint.

No pronouncedly glauconitic sandy facies such as that in the foregoing boring can be proved here, but it is clear that the lowest stratum has contained shelly-gravel components. The largest quantity of glauconite is in the lowest sample. 
Galten [78.9].

There is good sample material from a boring at Galten Dairy, about 13 $\mathrm{km} \mathrm{S}$ of Randers, providing ample information as to conditions at the boundary between the Paleocene and the tuff-bearing series.

$68 \mathrm{~m}$. Light reddish and greenish Plastic clay, all very calcareous.

68-80 m. Non-calcareous greyish-black clay with tuff and metamorphosed Mo-clay.

$80 \mathrm{~m}$. As above. Glauconite $12 \%$.

80-84 m. As above,

$85 \mathrm{~m}$. Greasy, greenish-grey clay, which becomes slimy on stirring in water. Glauconite $2 \%$.

$90 \mathrm{~m}$.

$93 \mathrm{~m}$.

$95 \mathrm{~m}$.

$99 \mathrm{~m}$.

$105 \mathrm{~m}$. Almost non-calcareous, rather sandy grey clay, which does not become slimy on stirring. The mineral content is Paleocene, with glauconite grains, pyrite spheres and sponge spicules, as well as fine quartz grains. Calcium carbonate $1.2 \%$, glauconite $75 \%$.

$110 \mathrm{~m}$. As above. Calcium carbonate $1.8 \%$, glauconite $78 \%$.

$120 \mathrm{~m}$. As above. Calcium carbonate $1.6 \%$, glauconite $77 \%$.

$130 \mathrm{~m}$. Calcareous, sandy marl with foraminifera and other lime grains up to $0.5 \mathrm{~mm}$. Glauconite and quartz grains up to $0.2 \mathrm{~mm}$. Calcium carbonate $34.5 \%$, glauconite $51 \%$.

This boring shows distinctly that at a depth of about $100 \mathrm{~m}$ there is a marked boundary, visible both in the character of the rock and in the mineral content (Fig. 32 page 139). The slightly sandy rocks below $100 \mathrm{~m}$ are typical non-calcareous and glauconitic Paleocene rocks, whereas the greasy, slimy clays over $100 \mathrm{~m}$ are of a type found elsewhere in facies alternation with tuff-bearing strata and therefore placed to Eocene (HeLGE Gry in V. Madsen, H. Ødum and H. Gry 1935). This rock is extremely pyritic and the boundary between Paleocene and Eocene is thus marked by a sudden fall in the glauconite content.

Langaa [68.3] (F. 6. 45) (O. B. BøGGILD 1918 p. 87).

O. B. BøagtLD gives the following series:

13-19 m. Volcanic tuff.

19-25 m. Grey non-calcareous clay with tuff.

25-35 m. Grey calcareous clay.

$35-50 \mathrm{~m}$. Grey non-calcareous clay.

$50-54 \mathrm{~m}$. Grey calcareous clay.

54-59 m. Danian.

Danmarks Geologiske Undersøgelse. II. R. Nr. 61. 
However, there is tuff in samples from $34.5 \mathrm{~m}$ and $37.7 \mathrm{~m}$, and the clay in which the tuff occurs is not of Paleocene type, but corresponds exactly to the tuff-bearing clay elsewhere. The only samples with Paleocene are:

$50.2 \mathrm{~m}$. Grey marl, typical Paleocene with fine quartz sand, glauconite grains, pyrite spheres and sponge spicules. Calcium carbonate $17.8 \%$, glauconite $26 \%$.

$53.4 \mathrm{~m}$. As above. Calcium carbonate $21.0 \%$, glauconite $52 \%$.

$54.3 \mathrm{~m}$. This sample consists mostly of Danian flint, but also contains a quantity of pure fragments of a grey, rather sandy, marly limestone which is somewhat silicified. The mineral content is as in the overlying samples, but the rock is more sandy. Calcium carbonate $15.3 \%$, glauconite $85 \%$.

Here the thickness of the Paleocene must be at least $4 \mathrm{~m}$, at most about $17 \mathrm{~m}$ (Fig. 29 page 136). In any case it is thus very thin. The only samples known are from the lowest $4 \mathrm{~m}$ of the series, where the Paleocene is slightly calcareous. The rocks display a distinct and rapid transition from glauconitic, rather sandy rocks at the bottom of the series to more pyritic and more clayey rocks higher up in the series.

Jernit, near Hammel [78.3] (Hilmar ØDUM 1926 p. 44).

This boring passes through the Tertiary from Oligocene to Cretaceous. In the lower parts of the boring we have the following samples:

$210 \mathrm{~m}$. Red calcareous Plastic clay.

$215 \mathrm{~m}$. Grey greasy claý with tuff. Glauconite $25 \%$.

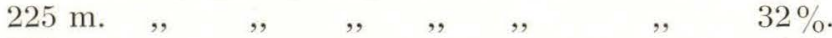

$230 \mathrm{~m} . \quad, \quad, \quad, \quad, \quad, \quad, \quad, \quad, \quad, \quad, \quad 6 \%$

$235-240 \mathrm{~m} . \quad, \quad, \quad, \quad, \quad, \quad, \quad, \quad, \quad, \quad 0 \%$.

$245 \mathrm{~m}$. Grey, slightly sandy clay with sponge spicules and pyrite in the form of diatoms and sponge spicules. Calcium carbonate $1.3 \%$, glauconite $68 \%$.

$250 \mathrm{~m}$. As above, but somewhat greasier. Calcium carbonate $2.5 \%$, glauconite $60 \%$.

$255 \mathrm{~m}$. As above. Calcium carbonate $14.5 \%$, glauconite $49 \%$.

$260 \mathrm{~m}$. Sample consisting of fine dust of grey clays. Calcium carbonate $26.8 \%$, glauconite $50 \%$.

$263 \mathrm{~m}$. Mixed sample mostly consisting of fine dust of clay. Washing produces a considerable quantity of flint fragments and some sandy particles, mostly calcareous grains, glauconite and pyrite.

$264.2-273.2 \mathrm{~m}$. A number of samples from various depths in this interval consist of very impure material. The principal element is fine dust formed through the mixing of the overlying deposits. Of particular interest at $265 \mathrm{~m}$ depth is a sample with mostly flint splinters. From $266.9 \mathrm{~m}$ and downwards there are pure small fragments of white, sandy, coccolith chalk interspersed among the other components.

273.2-326.1 m. Coccolith chalk. 
As the lower samples are very impure and consist of mixtures of rocks from different depths, it is difficult to obtain an exact picture of the series. The upper Paleocene boundary lies distinctly between 240 and $245 \mathrm{~m}$, the lower boundary presumably at $263 \mathrm{~m}$, where for the first time the sample contains typical flint. Apparently the coccolith chalk underlying the Paleocene has been very soft and has been mixed with the fallen material, so that only few pure fragments occur in the samples.

At the bottom the Paleocene series (Fig. 32 page 139) begins with slightly sandy strata, but upwards the rocks become more clayey. The content of calcium carbonate decreases upwards, the uppermost strata being almost non-calcareous. The glauconite content is fairly uniform, and most samples contain a little more glauconite than pyrite. Thus the marl is not the typical Kerteminde marl of the outcrops. Just at the transition from Paleocene to Eocene the glauconite percentage falls, and the lower part of the Eocene is extremely pyritic. Thus the boundary between Paleocene and Eocene reveals itself in the same manner as in the boring at Galten.

Skive [55.2] (H. 7. 3) (O. B. BøGGLD 1918 p. 86̣).

The samples from the lowest part of this boring are very badly labelled, for which reason the material was difficult to interpret. There are the following samples from the tuff-bearing series and downwards:

No. 7. $\quad 65.6-74.1 \mathrm{~m}$. Volcanic tuff.

No. 8. 74.1-114.3 m. Light reddish-grey and whitish, non-calcareous Plastic clay and tuff, which according to BøGGILD cannot have fallen down from overlying strata.

No. $9 \& 10.79 .1-114.3 \mathrm{~m}$. Mixture of pure small fragments of dark-grey, light reddish-grey and whitish clay, all noncalcareous.

No. 11. $\quad 91.0-113.6 \mathrm{~m}$. Same combination of rocks as the above, but with $2.9 \%$ calcium carbonate, which BøGGILD states comes from very small rock particles that are calcareous, whereas most of the clay fragments are non-calcareous.

No. 12. 114.3-117.9 m. Bryozoan limestone and flint.

O. B. BøagILD has the Paleocene beginning at $79 \mathrm{~m}$, where tuff no longer appears in the samples, and he gives the following credible distribution:

79- $91 \mathrm{~m}$. Grey non-calcareous clay.

91-114 m. Grey calcareous clay.

114-118 m. Upper Cretaceous.

It is not certain, however, that the non-calcareous clays in samples No. 9, 10 and 11 are Paleocene. They are very like the grey greasy clays 
found together with volcanic tuff and in facies alternation with Plastic clay in several parts of Denmark. The rocks contain both pyrite and glauconite, but sponge spicules are lacking and the clay is very greasy, becoming slimy on being stirred with water. Thus all that can be said about the Paleocene at Skive is that the thickness is very small and that marl occurs overlying the Cretaceous.

Sønderborg [169.28] (V. Madsen, H. ØDum and H. Gry 1935).

Two borings at Sønderborg, about 200 metres apart, revealed the same distribution of the rocks. Both were wash-borings, and the sample material, taken at intervals of 4 or 5 metres, was therefore rather impure on account of fallen material from overlying strata.

The tuff-bearing series - from 305 to $325 \mathrm{~m}$ - consists in the main of dark grey, pyritic, non-calcareous clay, subordinately of lighter grey Plastic clay, with secondary tuff. As a rule the samples do not contain glauconite. Counts give from 0 to $3 \%$ glauconite.

Under the tuff-bearing series there is a Paleocene series of $22 \mathrm{~m}$, from 325 to $347 \mathrm{~m}$, and under that bryozoan limestone. The samples of Paleocene reflect the following conditions: The basal stratum of the Paleocene is seen from a silicified sample which shows the contact with Danian flint. The rock is calcareous, sandy, with glauconite grains from 0.2 to $0.3 \mathrm{~mm}$ and very numerous sponge spicules. Glauconite $60 \%$.

Most of the Paleocene samples are of a more or less silicified, grey clayey rock, mostly non-calcareous. It contains no large sized sandy particles, but usually an abundance of sponge spicules. In a casual sample from the middle of the series glauconite has been counted at $45 \%$.

Uppermost in the Paleocene series there is a grey, sandy, non-calcareous rock, in which most of the arenaceous particles are quartz and glauconite. The principal grain size is $0.06-0.08 \mathrm{~mm}$. The mineral content is typically Paleocene, and there are some radiolaria and sponge spicules. The rock contains some few chalcedonized foraminifera. Glauconite: $92 \%$.

As almost all the rocks are greatly silicified it is difficult to say whether the lack of calcium carbonate is primary or secondary. Nevertheless, the occurrence of silicified foraminifera and a few slightly calcareous fragments among the non-calcareous rocks indicates that these rocks to some extent have contained some calcium carbonate. As to the series it can be definitely stated that at the bottom there is a calcareous, sandy facies that is glauconitic, over it are intermediate clayey rocks, and at the top again sandy glauconitic facies (Fig. 32 page 139). The boundary between the Paleocene and the tuff-bearing series is extraordinarily distinct, both in the rock character and in the glauconite percentage. 
Svendborg [164.42] (Hilmar ØDUm 1926 p. 26).

In the course of a boring at Svendborg Gasværk bryozoan limestone was found at a depth of $60-62.4 \mathrm{~m}$. A sample of the rock overlying the Cretaceous consists of a mixture of small stones, till, and pure fragments of Paleocene rocks.

One fragment consists of a very much silicified, sandy, calcareous, grey rock which to a great extent is composed of sponge spicules. In addition there are small quartz grains, glauconite and a little pyrite.

The remainder of the Paleocene fragments are slightly silicified, somewhat sandy, grey clay which is non-calcareous or almost so. It contains fine sand grains, some glauconite and a little pyrite. A few silicified foraminifera have been observed, and sponge spicules are present.

The boring provides no information as to the series, but it is of interest as it shows rock types similar to those at Sønderborg.

Skrøbelev, Langeland [173.4] (O. B. BøaGILD 1918 p. 97).

From the lower part of this boring there are the following samples:

66.5- $67.8 \mathrm{~m}$. Volcanic tuff and black-grey clay.

$76.9 \mathrm{~m}$. Brownish-grey, non-calcareous Plastic clay.

$82.5 \mathrm{~m}$. Brownish-grey, non-calcareous Plastic clay, glauconite $8 \%$.

$84.7 \mathrm{~m}$. Dark grey, fat, non-calcareous clay with fine sand particles, only very few sponge spicules. Glauconite $63 \%$.

$109.2 \mathrm{~m}$. Grey, slightly sandy marl, partly silicified. Sponge spicules frequent. Calcium carbonate $8.8 \%$, glauconite $90 \%$.

105.5-113.0 m. As above. Calcium carbonate $14.4 \%$, glauconite $82 \%$.

$113.0 \mathrm{~m}$. Bryozoan limestone.

Judging from the few samples the thickness of the Paleocene is about $30 \mathrm{~m}$, the glauconite percentage indicating that the clay at $84.7 \mathrm{~m}$ is Paleocene. If this is so, we have the same abrupt fall in the glauconite content at the transition from Paleocene to Eocene as was found at Galten, Jernit and Sønderborg (Fig. 32 page 139). The Paleocene at Skrøbelev is characterised by its low calcium carbonate content and preponderating glauconite content, like the rocks at Sønderborg and Svendborg.

\section{Gedser in Falster.}

At Gedser two deep borings go down into the Older Tertiary. Both were described by O. B. BøGGILD in 1918 (p. 116).

1. At the Station, 1886 [242.1] (B. 1. 1.).

From this boring there is only one sample of Tertiary clay marked 》- 13' to -372 '« $(4.1-116.8 \mathrm{~m})$. The rock mostly resembles the dark grey 
clays associated with the tuff-bearing Eocene series. It consists of grey, greasy, non-calcareous clay. Thus there are no Paleocene samples from this boring.

2. By the Railway Line, $2 \mathrm{~km} \mathrm{~N}$ of Gedser [242.3] (B. 1. 5.).

In this boring there are, according to O. B. BøGGILD :

0-19 m. Quaternary.

$19-87 \mathrm{~m}$. Clay and slate, Paleocene.

87-88 m. Hard slate (non-calcareous greensand-stone).

88-92 m. Senonian White chalk.

The samples are as follows:

47.1 m. Greenish, non-calcareous Plastic clay, which becomes very slimy on being stirred with water. The sample contains much pyrite, partly as concretions, partly in the form of radiolaria and diatoms. Glauconite $8 \%$. The sample is undoubtedly Eocene.

$78.5 \mathrm{~m}$. Grey, non-calcareous clay containing a little fine sand. Glauconite in small particles, pyrite in small spheres or in the form of sponge spicules. On the other hand the sample has no sponge spicules preserved as opal or chalcedony. Glauconite $64 \%$. The sample is probably Paleocene.

$88.2 \mathrm{~m}$. The sample contains a few pure fragments of silicified greensand-stone. Evidently the rock has been rather fine-sandy and, besides quartz, contains considerable quantities of glauconite and a great abundance of sponge spicules which have been converted into chalcedony. This sample is non-calcareous, but there is calcareous greensand-stone in the moraine at Gedser.

. $91.0 \mathrm{~m}$. Yellowish chalk like Senonian White chalk.

As the uppermost Tertiary clay sample is Eocene, the Paleocene is not so thick as was previously assumed. The thickness is 12.5 metres at the least, 53.9 metres at the most. That the lowest sample is non-calcareous may possibly be a secondary phenomenon and due to silicification. Of the two Paleocene samples the lower one is the more sandy and the richer in glauconite.

\section{Summary of the Borings.}

A survey comprehending all the borings makes it clear that the development of the Paleocene varies greatly in the different parts of the country.

The thickness is extremely variable, less than 20 metres at some places and more than 150 metres at others.

The least thicknesses were found in two areas, Mid Jutland and the most southerly part of Denmark. At those localities where both the upper and the lower Paleocene boundaries are known the thicknesses are as follows: 


$\begin{array}{ll}\text { Skive maximum } 23 \mathrm{~m} . \\ \text { Langaa maximum } 17 \mathrm{~m} . \\ \text { Jernit maximum } 23 \mathrm{~m} . \\ \text { Wedellsborg } & 24 \mathrm{~m} . \\ \text { Sønderborg } & 22 \mathrm{~m} . \\ \text { Skrøbelev } & 30 \mathrm{~m} . \\ \text { Gedser maximum } 54 \mathrm{~m} .\end{array}$

Between these two areas with small thicknesses the Paleocene sometimes attains to very much greater dimensions, but the variations from place to place in Sealand, Funen and East Jutland cannot be determined, owing to the fact that at no place has the series been found to its full extent. Either the upper deposits have been abraded by the ice or the Paleocene has not been bored right through. An impression of conditions as they are will be obtained from the following figures, giving the greatest thicknesses observed:

$\begin{array}{lr}\text { Besser } & 77 \mathrm{~m} . \\ \text { Fredericia } & 54 \mathrm{~m} . ? \\ \text { Sværup } & 57 \mathrm{~m} . \\ \text { Ulriksholm } & 50 \mathrm{~m} . \\ \text { Hulby } & 104 \mathrm{~m} . \\ \text { Slagelse } & 76 \mathrm{~m} . \\ \text { Sorø } & 156 \mathrm{~m} . \\ \text { Christiansdal } & 44 \mathrm{~m} . \\ \text { Ringsted } & 50 \mathrm{~m} . \\ \text { Holbæk } & 46 \mathrm{~m} . \\ \text { Stedstrup } & 62 \mathrm{~m} .\end{array}$

A comparison of these great thicknesses with the slight dimensions in Mid Jutland and South Denmark leaves a distinct impression that in this country the Paleocene has been deposited in a basin which in the main has extended over Sealand, Funen and the southern part of the Cattegat. A consideration of the distribution of the rock types confirms this impression, for the glauconitic rocks that were presumably deposited nearest the coast are to be found in the periphery of this area, and the pyritic formations from deeper water mostly in the middle.

\section{Distribution of Rock Types.}

In the area between Holbæk, Roskilde, Køge and Ringsted we have a very large number of borings in which 30 to $45 \mathrm{~m}$ of greensand have been found overlying the Cretaceous. As a rule, more complete information is unprocurable, as in most cases there is an absence of boring samples; but 
when there are samples from different levels (as for instance Roskilde and Holbæk), it will be observed that as a rule there is a decreasing sand content and glauconite content as we move upwards in the series, the rock passing into a more pyritic marl. One boring in this area (Stedstrup) shows that higher up in the series there is a facies alternation between pyritic marl and glauconitic greensand deposits. Facies alternations of this kind have been found as far to the west as at Sorø.

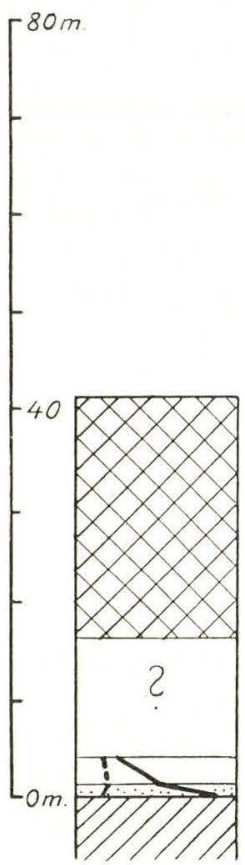

Langaa

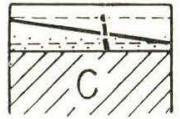

Ebeltoft

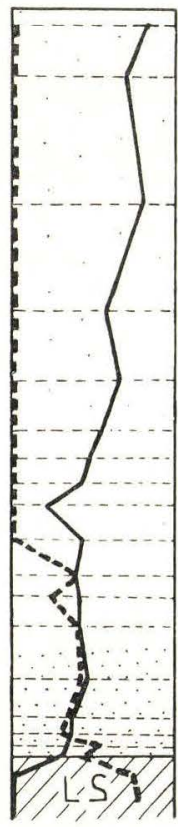

Besser

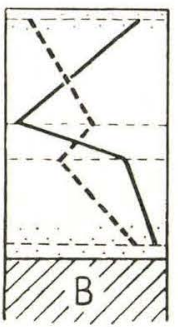

Dalum

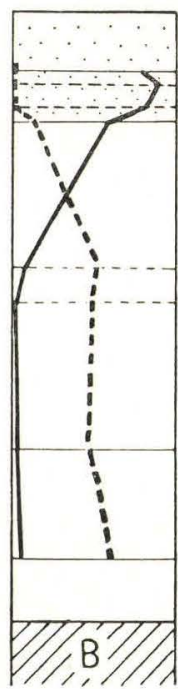

Ulriksholm

Fig. 29. Borings showing Paleocene overlying Danian. Cross-hatched area: tuff-bearing series; hatched area: Danian limestone, B: bryozoan limestone, C: coccolith chalk, LS: lime-sand. Broken line: calcium carbonate, continuous line: glauconite. The degree of stippling indicates the higher or lower sand content in the Paleocene rocks (see page 112).

Typical greensand has been found as far north as on Sjællands Odde, southeast to Haslev and southwest to $15 \mathrm{~km}$ south of Sorø. Accordingly we may take it that over the greater part of Sealand there is, lowest, a glauconite - lime sand facies, and over it a facies alternation between this facies and more pyritic marl.

In the tracts round about Slagelse and Korsør we have typical Kerteminde marl directly overlying the Cretaceous, and the same conditions recur in the east part of Funen. In most cases the marl is extremely pyritic, 


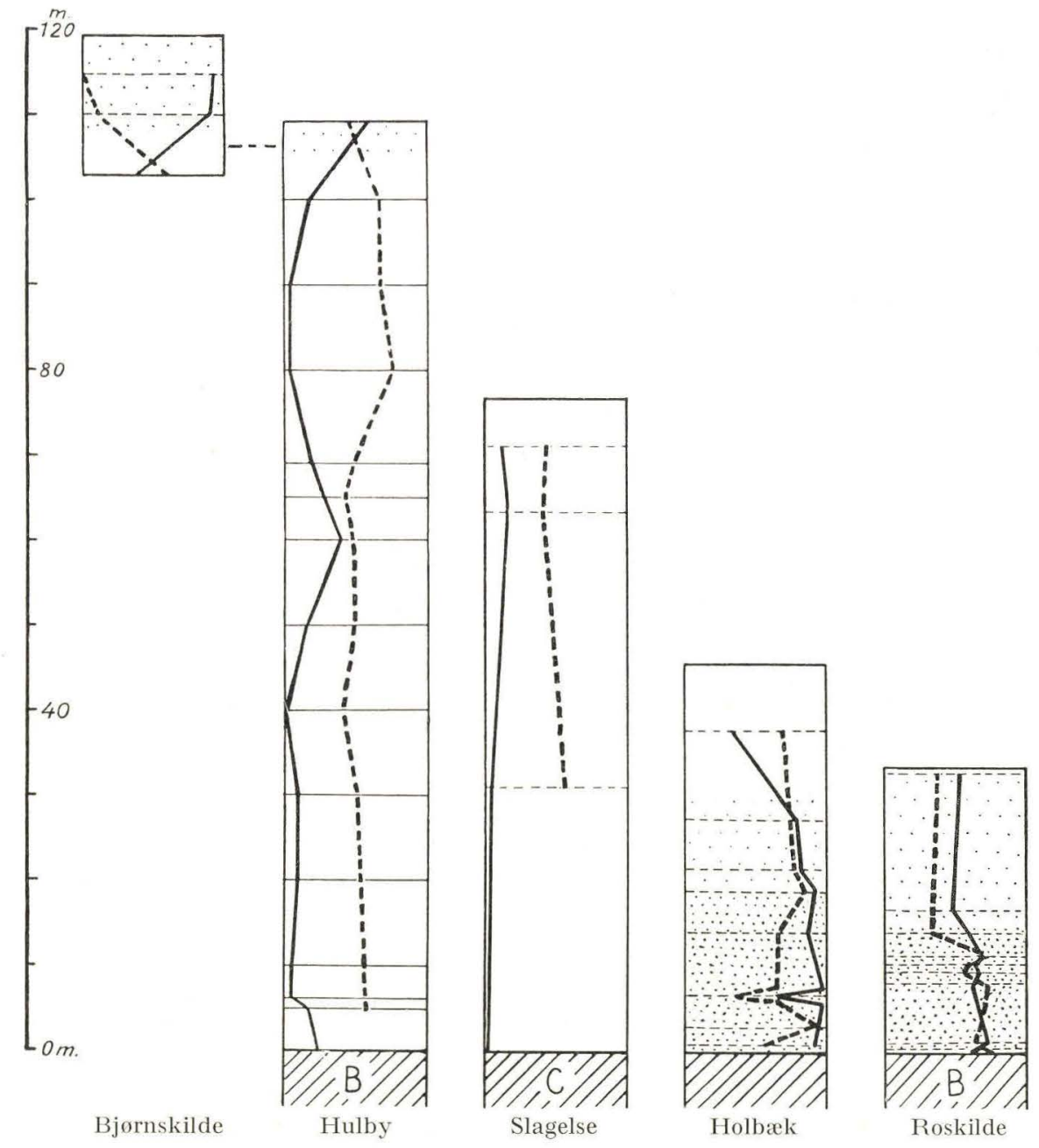

Fig. 30. Borings showing Paleocene overlying Danian.

but a slight degree of facies alternation is observable in the fact that the glauconite content sometimes rises at certain levels. The thickness of the marl is greatest in Sealand (Hulby, about $104 \mathrm{~m}$ ), less in Funen (Ulriksholm, about $50 \mathrm{~m}$ ). Upwards the marl passes into a non-calcareous, more sandy, glauconitic rock (non-calcareous greensand).

In the other parts of Funen, and at Fredericia, we mostly find marl that is closely related to Kerteminde marl, but usually containing more glauconite. This marl likewise passes into a non-calcareous rock which, however, is not so pronouncedly sandy and glauconitic as in the localities more to the east. Similar conditions have been met with in Samsø, where the lower part of the series contains a quantity of lime sand. 
In Djursland only the lowest parts of the series are known from borings, but the dislocated outcrops reveal the nature of the other parts of the

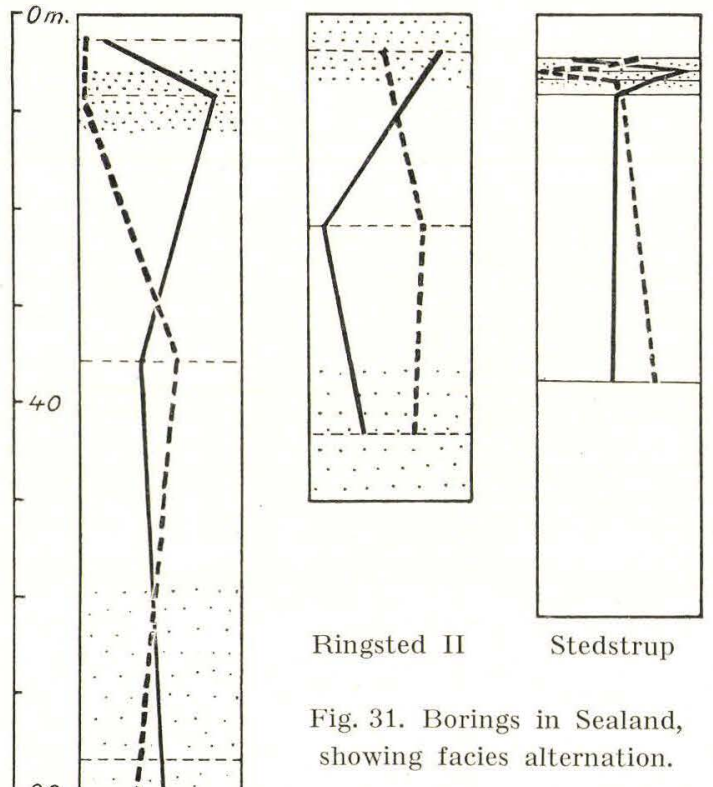
series. The most characteristic feature of conditions in Djursland is that there is scarcely any lime sand in the rocks, whereas calcareous mud forms the bulk of the rocks. Consequently, at the bottom there is glauconitic marl of slight thickness. It passes into pyritic marl, above which we are warranted in presuming that there is marl with a facies alternation between glauconitic and pyritic strata. At the top there are presumably non-calcareous, sandy, glauconitic rocks.

West of Djursland the Paleocene is only of slight thickness. The rocks are not very characteristic, usually sandy or clayey, with a low content of calcium carbonate. They contain both glauconite and pyrite, though in most cases there is more of the former than of the latter. Exactly similar facies are to be found in the southernmost localities in Denmark: Sønderborg, Svendborg, Skrøbelev and Gedser.

The results to which this study of the borings has led may be summarised in the following points:

1. The rocks that are rich in lime sand occur mostly in Sealand, and they are always rich in glauconite (Fig. 30).

2. The Paleocene series always begins with calcareous rocks and passes into non-calcareous varieties. Alternation between calcareous and non-calcareous rocks has been found, but often a low content of calcium carbonate in the calcareous series is due to silicification. 
3. In the calcareous Paleocene a considerable facies alternation has been found between glauconitic, most often sandy, and pyritic, most often

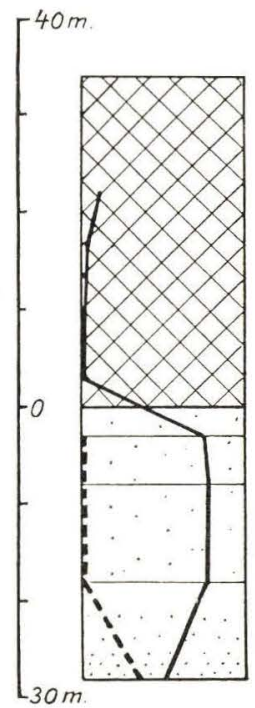

Galten clayey strata, whereas the non-calcareous facies is always rich in glauconite (Fig. 31).

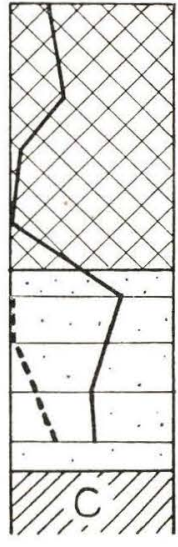

Jernit

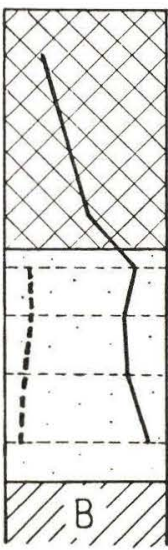

Wedellsborg

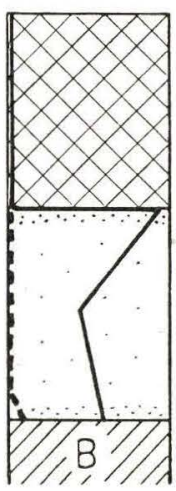

Sønderborg

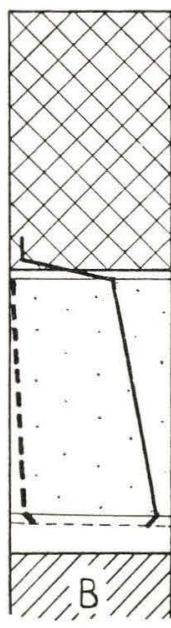

Skrøbelev

Fig. 32. Borings showing relation between Paleocene and tuff-bearing series.

4. The boundary between Paleocene and Eocene is marked by an abrupt change from glauconitic to pyritic rocks (Fig. 32).

5. In the tract round Korsør-Nyborg the pyritic marl attains its greatest importance and in fact forms the basal deposit of the Paleocene. The farther we go from this area, the more predominant do the glauconitic rocks become.

\section{Conclusion.}

A petrological investigation has been made on the Paleocene rocks and the Paleocene series in Denmark. The more consolidated rocks have been examined in the form of thin sections, the incoherent rocks by mechanical analyses and by quantitative mineral analyses of the fractions. Characteristic features of the series have been brought to light in boring sections by examining the sand content, calcium carbonate content, and the proportions of glauconite to pyrite. 


\section{Paleocene Limits, Underlying and Overlying Rocks.}

The substratum to the Paleocene consists of calcareous rocks of the Danian. In some places the rock is bryozoan limestone, in others limesand, and in others again fine-grained calcareous rocks (coccolith chalk). Possibly the substratum at Gedser is Senonian White chalk.

It sometimes happens that the nature of the substratum is different even in localities that lie very closely together. In Copenhagen, for example, the Paleocene in the South Harbour lies on a fine-grained limesand rock (foraminiferal limestone), whereas at Vodroffsvej it lies on at least $2 \mathrm{~m}$ of coarse lime-sand. The inference thus is that fairly thick limesand deposits must have been broken down at the commencement of the Paleocene. The disintegrated lime-sand forms part of the Paleocene greensand, and this is the explanation of the fact that the sandy Paleocene is of considerable thickness. In the region round Køge (Lellinge) we find that the Paleocene overlies bryozoan-fragment limestone, but close by there are lime-sand deposits that are younger than that limestone, and the thickness of the sandy Paleocene shows that large quantities of Danian rocks have also been broken down there. The fact that at Hvalløse and Svejstrup there are pebbles of foraminiferal limestone, whereas the substratum is coccolith chalk, and that there are large quantities of derived Ceratotrochus milthersi in the basal stratum of the Paleocene, whereas this fossil does not occur in the surrounding rocks, is one more proof that large quantities of Danian have been disintegrated by the Paleocene transgression.

The close of the Danian period is one of emergence, and there was a deposition of lime-sand and calcareous mud, which are simply derivatives of the other Danian rocks. New physical conditions were introduced with the Paleocene transgression, and there was a transportation of allochthonous terrigenous material to Denmark. Accordingly, the boundary between Danian and Paleocene is marked by an unconformability (which can be followed down into North Germany (Gagel 1922) and over to Scania (Holst \& Grönwall 1907)) and by changes in the character of the sediments.

The upper limit of the Paleocene is known only from borings, and, as the strata on either side of the boundary between Paleocene and Eocene are non-fossiliferous, the characters of the rocks have to be used for determing the boundary.

The non-calcareous rocks placed to the Paleocene are in a mineralogical sense analogous to the calcareous rocks. They are grey, somewhat sandy clay or clayey sand, never very greasy clays. Paleocene features include 1) the occurrence of pyrite in the form of small spheres gathered into con- 
cretions of the shape of diatoms, 2) the presence of needle-shaped sponge spicules of the same type as in the other rocks of the Paleocene and in the same state of preservation, 3) the presence of the same types of radiolaria and 4) the circumstance that the rocks often are silicified. In the non-calcareous Paleocene glauconite grains are often present.

Overlying the non-calcareous Paleocene is a series of rocks that are characterized by containing beds of tuff (though very little in the lower part), and over them red and grey Plastic clay.

There is great variation in the tuff-bearing rock series. In the Limfjord areas they consist of Mo-clay (diatomaceous earth), though basally of very greasy greenish or yellowish-grey clay. In other visible occurrences there is metamorphosed Mo-clay in facies alternation with greasy, dark-grey clay. Borings have at a few places revealed metamorphosed Mo-clay (for instance at Galten (page 129)), but in most cases a series of very greasy clays, oftenest of greyish colour. At times the rocks can scarcely be distinguished from typical grey or greenish Plastic clay, but generally they are of the same type as the greasy, dark-grey tuff-bearing clay of the outcrops. The characteristic features of these rocks are that on being stirred with water they become very slimy in consistency, and that they contain large quantities of opal and pyrite. The pyrite occurs as small spheres and as pseudomorphs on diatoms and radiolaria (the pyrite reproduces every detail of the structure of the siliceous organisms, in contrast to conditions in the Kerteminde marl, where the diatoms are full of pyrite spheres). Silicified rocks do not occur in the tuff-bearing series.

It is thus evident that the rocks in the tuff-bearing series are very different from the Paleocene rocks, and in the borings the boundary between Paleocene and Eocene is visible both in the rock character and in the glauconite content. The boundary between Paleocene and Eocene is marked by an abrupt change from glauconitic, slightly sandy, to pyritic, very greasy clays (Fig. 32 page 139). This difference in glauconite and pyrite content indicates sudden changes in the natural conditions at the transition between Paleocene and Eocene. The probability is that the disturbances which cause volcanic activity have also altered the geographical conditions of the sea and with them the natural conditions, whereby the character of the rocks in the Eocene became different to that of those in the Paleocene. As the rocks in the tuff-bearing series are very different from the Paleocene rocks, but partly identical with Eocene Plastic clay, it is natural to place the tuff-bearing series to the Eocene.

\section{Mineral Content of the Paleocene Rocks.}

According to their origin a distinction must be made between the following groups: 
1. Components that have come from the substratum to the Paleocene, disintegrated by the transgression of the Paleocene sea. 2. The allochthonous-clastic components. 3. Components formed by chemical processes in the sea or on the sea floor. 4. The organic components (the content of micro-organisms). 5. Components formed by cementation, weathering, and so on.

1. Components that have come from the substratum to the Paleocene. Everywhere in Denmark the Paleocene rests upon calcareous rocks, and a large part of the calcareous particles in the Paleocene have come from disintegrated limestone. This is true first and foremost of the lime sand and a large part of the calcareous mud in the lower parts of the Paleocene, as well as of limestone pebbles and derived glauconitized Danian fossils from the conglomerate strata. The quantity of these components is greatest immediately over the Cretaceous, and decreases upwards.

The occurrence of limestone pebbles which are not petrographically in accord with the limestone of the substratum (Copenhagen, Hvalløse, Svejstrup) shows that in the lower Paleocene the calcareous components are not autochthonous in the strict sense of the word. Yet they have come from a region with narrow limits, and it would scarcely be correct to call them allochthonous. A new term is therefore introduced, "a n chi-a u to chthonous", as a denomination for particles from a limited area, within which they have been transported only a short distance, so that they are "almost, but not quite" autochthonous.

It is possible that the anchi-autochthonous components in the Paleocene include — besides the calcareous particles — a small quantity of quartz grains which may have come from Danian limestones. Furthermore, the glauconite occurring in the form of rounded or lobate, smooth-edged grains, is also anchi-autochthonous.

2. The allochthonous-clastic components are partly sand, partly clay. They play no great part in the basal sediments of the Paleocene, where the anchi-autochthonous components predominate, but on the whole increase in quantity upwards in the series, and finally form the greater part of the rock in the non-calcareous series.

The quantitative counts show that more than anything else the allochthonous components are quartz, in addition to which there are some few per cent. felspar (orthoclase, microcline and subordinately plagioclases) and white mica, principally in the finest sand fractions. Of accessorial components green hornblende, tourmaline, zireon, garnet and titanite have been found.

3. The components formed by chemical processes in the sea or on the sea floor are glauconite, pyrite, calcite and siderite.

Glauconite and pyrite may be regarded as indicators of the natural 
conditions under which the sediments were deposited. The glauconite is formed in sea-water containing oxygen, the pyrite in water containing little oxygen, a fact which has been utilised in the examination of variations in the series when counting the percentual ratio between glauconite and pyrite in the rock samples from the borings. The exposed occurrences and the boring samples show that some rocks are glauconitic, others pyritic.

The glauconite occurs:

1. as rounded or lobate, smooth-edged grains, in most cases quite pure or containing finely distributed pyrite.

2. as pigmentary glauconite which has grown at the expense of organic calcareous components. This includes the irregular reticulations, strips and lumps, which have the usual aggregate structure. (Observe especially the small glauconite prisms retaining the shape of the calcareous prisms of the large shells of lamellibranchs (see page 28). In addition, masses of glauconite which both in shape and in optical arrangement of the small crystals agree with the calcium carbonate of which they are formed (Hvalløse page 84).

3. as pigmentary glauconite that has filled the interstices between the grains without dissolving other components. This includes for instance glauconite between quartz grains in fragments of quartzite. Furthermore, glauconite in some of the glauconitized pebbles.

4. as glauconitic mud, which in the unconsolidated sediments occurs between the sand particles in such a manner that it passes into the calcareous-clayey mud of the rocks (Plate 1 Fig. 6).

Observations of thin sections show that the pigmentary glauconite and the glauconitic mud occurring in the ground-mass of the rocks pass into each other and thus must have been formed simultaneously. This fact shows with great distinctness that in its original, primary form glauconite occurs as undifferentiated glauconite substance which may deposit itself anywhere in the glauconite-bearing sediments.

The view that glauconite is formed as a colloid is now generally accepted (Caspari 1910; Hummel 1922; Berz 1921; Hadding 1932). Most investigators assume that in time colloidal glauconite passes into crystalline form, and we see the theory propounded that all recent glauconite is colloidal, and that only the fossil glauconite can be crystalline (HummeL 1922). In that case a long time would elapse between formation and crystallisation, and this is contradicted by the manner in which glauconite sometimes occurs at Hvalløse as a pseudomorph after calcium carbonate, so that the optical orientation of the glauconite is in agreement with that of the calcium carbonate. The glauconite having replaced the carbonate of lime so that the glauconite particles lie orientated, it must have been crystallised simultaneously with its deposition. Rapid crystallization, however, is not the normal process, for much the greater quantity of glau- 
conite displays the fine aggregate structure that is presumed to be associated with its conversion from gel to crystalline glauconite.

It has been shown in the foregoing that the glauconite grains proper can be distinguished by their colour from other glauconite masses with which they occur, and that these grains therefore must be older than the pigmentary glauconite and the glauconitic mud (page 34). Consequently the glauconite grains must be secondarily bedded in the sediments. This does not signify that there is a great difference in the time at which they were formed, or a great distance between the place where they were formed and the place where they were deposited. On the contrary, the sudden occurrence of the grains in large numbers together with glauconitic mud and glauconitic pigment shows that the grains have been formed together with the other glauconite, but that there has been a process whereby grains of sand size have been formed. BERz's assumption that these grains are formed by conglomeration of very fine, suspended glauconite floccules seems to contain some probability (BERz 1921, p. 81). The difference between the glauconite grains and pigmentary glauconite and mud would thus be that the latter types have been deposited in their original form, whereas the grains are formed of the same undifferentiated glauconite by the movement of the waves. The grains would then behave as clastic components and be deposited more closely to or more remotely from where they were formed, that is to say they become anchi-autochthonous.

The glauconite grains having been transported some distance, great interest attaches to an investigation of their size in relation to the other transported components of the sediments, and we find that the glauconite grains have not always the same size as the other components, as has previously been contended (CAYEux, BERz). A comparison between the rock types and their position in the series has shown that the size of the glauconite grains depends upon the degree of sorting of the sediments and the intensity of the movement of the water. For these conditions I have set up the following rules (page 89):

In the unsorted or poorly sorted sediments, the glauconite grains group themselves about a main grain size that is governed by the agitation of the water strata in which the glauconite grains are formed, not by the agitation of the water on the sea floor where the glauconite is deposited. For this reason we find in such sediments a special grouping of the glauconite grains, whereas the grain size of the other components is independent of that of the glauconite.

In the sorted sediments, the glauconite grains are sorted together with the other components. For that reason we find in the sorted rocks the same distribution proportions for glauconite as for the other components. 
The pyrite varies in its behaviour in the pyritic and in the glauconitic rocks.

In the pyritic rocks, that is to say those formed in a medium poor in oxygen, the pyrite occurs principally in the form of concretions made up of very small spherical concretions, just like the ferrous sulphide in the Black Sea (Androussow 1897; Ussing, in V. MADSEn 1902). Very often the shape of the concretions reveals that they were formed in diatoms (Plate 2 Fig. 2). This form of pyrite must have been created in the reducing sea-water and in close association with the deposition of the sediments.

In the rocks that are richest in glauconite the pyrite masses in most cases are of irregular shape. Here the pyrite may have been formed at the expense of the glauconite or the calcium carbonate, and the pyrite later has spread in the matrix between the grains. All observations go to prove that in these rocks the pyrite has been formed after the glauconite but before the cementing of the rocks (page 31). It appears from Murray \& IRVINE's investigations (1895) that the content of oxygen in the water on the sea floor decreases as soon as we get down under the surface of the deposits there. It is therefore presumable that in the Paleocene glauconitic rocks the pyrite was formed as soon as the sediment had been covered by material deposited later.

Calcite. The occurrence of extremely fine crystals of calcite in the mud of the Kerteminde marl indicates that there has been a chemical precipitation of calcite, and I consider it probable that a large part of the calcareous mud in the Paleocene marl has been sedimented by chemical precipitation. This assumption is also supported by the fact that a homogeneous marl series more than 100 metres thick has been deposited with calcareous mud, of which only a small part is definable as organic or anchi-autochthonous.

Siderite occurs in very small quantities in a few samples, in the form of small crystals. At what point of time it has been formed I am unable to decide; most probably, however, it was after the sedimentation.

4. The organic components (micro-organisms).

Coccoliths occur in rather small quantities in the very sandy deposits, but are very frequent in the marl. Diatoms rarely occur in the sandy deposits, but in the marl, especially in Kerteminde marl, triangular and disk-shaped types occur in large numbers. On extremely rare occasions the opal substance of the shell is preserved, but in most cases the original shell has been dissolved and only the shape of the pyrite concretions shows how numerous the diatoms have been. Foraminifera are frequent in all calcareous Paleocene deposits. Radiolaria occur in most Paleocene rocks. They are always few in number, and most numerous in the non-calcareous Paleocene. Siliceous sponges are common in all 
parts of the series, rarest in the Kerteminde marl. Usually the sponge spicules are agglomerated in separate layers which afterwards have been silicified. They are preserved in the form of opal or chalcedony.

5. Components formed by cementation, weathering, etc.

The Paleocene rocks may be cemented by calcite or by opal or chalcedony.

Cementation by calcite starts from the calcareous grains in the rock, there being a deposition of calcite crystals which are in optical continuity with the calcareous grain inside; under continued growth a mosaic appears, finer or coarser according to whether the cementation begins from many fine grains or only from the coarser grains. The forming of an oolitic calcite zone in the interstices between the calcareous grains has been observed in a single occasion (Copenhagen, page 29; Plate 1 Fig. 2).

Cementation by opal is very common in the Paleocene and is met with at all levels in the series. When present the rock ground-mass is thoroughly impregnated with opal. In many cases there has been a continued development of the silicification, observable by the fact that there has been a dissolution of calcareous particles and opal has taken their place (some cherts in the marl series). The opal substance must have originated from dissolved siliceous organisms: sponge spicules or diatoms, whose opal substance almost always has disappeared.

The formation of chalcedony. Chalcedony is formed mostly by the crystallisation of opal. It has been found that the formation of chalcedony mostly begins with the conversion of sponge spicules to chalcedony, and from that chalcedony with continued growth there is a deposition of stalactitic chalcedony, until at last a flinty mass has been formed, in which it is possible to discern the cavities of the spicules and remains of calcareous grains (Plate 2 Fig. 3). - In a sample of greensand limestone from Copenhagen a zone of stalactitic chalcedony has been found in the interstices between the calcareous grains (page 30; Plate 1 Fig. 2).

The weathering processes. As a rule the weathered rock samples are more yellow in colour than the fresh samples, due to the formation of limonite. It has been shown that pyrite may be weathered into limonite, and glauconite into limonite and opal (page 101). Usually the original form of the grain is preserved after weathering. Newly-formed gypsum crystals often occur in small numbers together with the weathered rocks. 


\section{The Mechanical Analyses.}

Certain circumstances connected with the deposition of the sediments and the sorting processes are observable in the mechanical analyses. In the series, for example, there are characteristic changes from below upwards, viz.:

1. Decreasing quantities of sand and increasing quantities of mud, 2. decreasing grain size of the sandy particles, and 3. better sorting of the material. The latter is best displayed in the distribution pyramids from Hvalløse (Fig. 19 page 83).

The few samples containing gravel particles must be placed to two types according to the degree of sorting.

Shelly gravel and the other samples with gravel particles from the Vestre Gasværk series belong to a deposit of well-sorted rocks and come from strata lying rather above the base of the sedimentation series. In these samples the sandy particles group themselves about a grain size that is of the same dimensions as in the over and the underlying strata, whereas the gravel particles are grouped about a grain size that is about 16 times the diameter of the sand particles (page 42 and Fig. 10 page 44). Thus the particles conform to UDDEx's transport-law on the relation between the sizes of suspended and rolled material in well-sorted deposits (J. A. UDDEN 1914, p. 737). Contrasting with the well-sorted gravel from Vestre Gasværk are the basal deposits from Hvalløse and Svejstrup (Fig. 19 p. 83 and Fig. 22 p. 93). These rocks have flat, broad distribution pyramids, and the distance between the maxima of the gravel and the sand is evidently accidental. Poorly sorted rocks of this kind seem to be characteristic of the basal strata of the transgression. The explanation must be that the erosion and deposition at the beginning of the transgression proceed so quickly that it becomes apparent in the deposited sediment. Only some way up in the series is there a balance between the eroding forces and the deposition of sediment, and the rock acquires a higher degree of sorting.

\section{Quantitative Analyses and Types of Sediments.}

The quantitative analyses provide a numerical impression of the mineralogical composition of the rocks. The various fractions have been examined quantitatively, and it has turned out that the mineralogical composition varies with the grain size. Regularity in the variation becomes clearest when, on the basis of the quantitative percentual counts and the mechanical analysis, we calculate the distribution of the various mineral components in the various grain sizes, that is to say, resolve the original mechanical analysis into mechanical analyses of the various components. 
Naturally, most interest attaches to the distribution of the more or less transported components, lime grains, glauconite grains and allochthonous grains (quartz etc.), and the distribution of these components has been illustrated by graphs showing the relation between the grain size and the quantity of the components in question.

By means of the analyses it is possible to distinguish between different rock types which pass into one another in a definite order.

The quantitative analyses show that some rocks are glauconitic (formed in agitated, oxygenous water), others pyritic (formed in stagnant water poor in oxygen). The two groups of rocks pass into each other by means of intermediate types.

It appears from the distribution curves that the particles either may group themselves about a maximum of sand grain size or distribute themselves in such a manner that the quantities are the greater the finer the grain size is, i. e. the maximum lies in the mud.

The separation of the rock types is made first of all on the basis of the glauconite and pyrite content and according to the grain size of the transported components, whether they occur mostly as sand or as mud. It is thus possible to distinguish the following types:

1. Calcareous greensand. Typical Paleocene greensand is characterised by containing considerable quantities of lime sand, some glauconite sand, and oftenest only little quartz sand. Generally the three components are sorted round about the same maximum, though the greensand deposits lying just over the Cretaceous substratum are less well sorted. Rolled Danian fossils and Danian limestone pebbles are mostly associated with the basal stratum. Much the greater part of the calcareous constituents is anchi-autochthonous. Pyrite is only sparsely present as a rule.

2. Clayey greensand. This is characterised by containing lime sand and glauconite sand, sorted in the same grain size, and a large quantity of mud, much of which is allochthonous clay. Pyrite, which especially occurs in the same manner as in the intermediate and pyritic rocks, is more frequent than in the greensand.

3. Glauconitic marl. This rock is an extremely glauconitic rock, its coarser particles mostly being glauconite grains grouped about a special maximum of sand size. Of calcareous and allochthonous sandy components there are only fine particles, grouping themselves with greater and greater quantities the finer the grain size is. Thus the rock is a marl type which, besides calcareous mud and allochthonous clay, contains anchi-autochthonous glauconite sand.

4. Intermediate marl. A number of rock samples contain no coarse sand particles at all, merely fine grains of lime, glauconite and allochthonous material, whose maximum lies in the mud. A considerable part 
of the calcium carbonate is organic (coccoliths, foraminifera) or has been chemically precipitated. The rocks contain quite a quantity of pyrite, which occurs in the same manner as in Kerteminde marl (see next type). Having regard to all its components the rock is a mud rock, forming the transition from the glauconitic facies to the typical Kerteminde marl.

5. Kerteminde marl. This is the extremely pyritic marl, containing only extremely few sandy particles. Most of the rock is calcareous mud and allochthonous clay, in addition to a considerable quantity of pyrite, which occurs in the form of small spheres, often agglomerated into larger concretions that are triangular or disk-shaped and have been formed in diatoms. A large part of the calcium carbonate is organic (coccoliths, foraminifera) or has been chemically precipitated. Glauconite is absent or extremely rare.

6. Non-calcareous greensand. The only non-calcareous rock analysed (Rugaard) must be designated as non-calcareous greensand. It is characterised by containing well-sorted sand as well as a quantity af clay. The sand grains are partly quartz, partly glauconite. Pyrite is not especially common. Similar types have repeatedly been found in borings over the calcareous rocks of the Paleocene.

7. Non-calcareous clay. The more clayey, non-calcareous Paleocene rocks have been found in borings only. In addition to clay they only contain fine sand, partly quartz, partly glauconite grains. Pyrite of the same form as in the Kerteminde marl is often of frequent occurrence, but as a rule there is less pyrite than glauconite.

\section{Series and Facies.}

In the various sedimentation series there regularly occur certain changes in the rock character from the bottom to the top of the series. In the lower and middle parts of the Paleocene series these typical changes are as follows; -

1. Transition from rocks with lime sand to rocks with calcareous mud.

2. Transition from clastic rocks to organogenous and chemically sedimented rocks.

3. Transition from glauconitic to pyritic rocks.

In the main these changes designate the transition from rocks formed in agitated, oxygenous water to rocks formed in still, non-oxygenous water. A considerable number of these series seem to have been developed on account of changes in conditions of erosion and in water movements, so that the various rocks occur in facies alternation with one another (e. g. Holme page 106).

In the upper part of the Paleocene there is a transition to slightly sandy, glauconitic, non-calcareous rocks (see Borings). 
Disregarding the facies alternation due to slight changes in erosion and water movements, it will be found that the rocks in the Paleocene series follow one another in the order below:

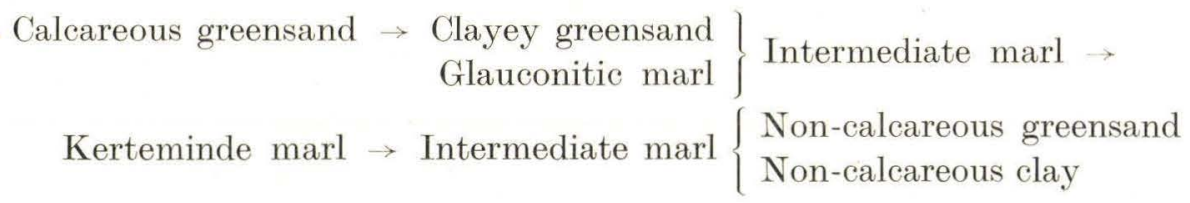

As a whole this series forms a single cycle of sedimentation, with glauconitic, partly sandy rocks, deposited in agitated water, in the lower and upper parts of the series, and pyritic marl, deposited in still and presumably deeper water in the middle, but the development of the series in the various parts of Denmark is connected with differences in the character of the substratum and in the natural conditions in the Paleocene sea.

At the very beginning of the Paleocene transgression there have been different natural conditions in different areas. This is to be seen by the fact that the series as a rule begins with glauconitic rocks deposited in agitated, oxygenous water, but in the district round Korsør-Nyborg it begins with pyritic rocks, deposited in still and non-oxygenous water.

The relation of the rocks to the substratum varies according to whether the basal stratum of the Paleocene is glauconitic or pyritic.

At those places where the basal Paleocene deposit is rich in glauconite we find that the building up of the Paleocene rocks is associated with the disintegration of the Danian deposits. Where the substratum has consisted of coarse calcareous rocks (bryozoan limestone, lime-sand), the sandy Paleocene acquires great thickness, as much anchi-autochthonous lime sand is included in the Paleocene (Copenhagen: sandy Paleocene on lime-sand; Lellinge: sandy Paleocene on bryozoan-fragment limestone, etc.). Where the substratum is fine-grained calcareous rock (coccolith chalk, perhaps White chalk), the sandy Paleocene series quickly pass into marl (Hvalløse: slight thickness of sandy Paleocene on coccolith chalk; Svejstrup: Paleocene marl on coccolith chalk). Thus it is clear that the glauconitic rocks must have been deposited in agitated water, where the disintegration of the Danish deposits has been great.

Where the basal Paleocene deposit is pyritic we find mud deposits, even on coarse calcareous rocks of the Danian (Slagelse, Hulby and Ulriksholm: Kerteminde marl on coarse bryozoan limestone). Thus at these places no great quantities of the components from the limestones of the substratum get into the Paleocene, which is evidence that the pyritic sediments have been deposited where erosion and water movement have been extremely slight. 


\section{Résumé.}

Den foreliggende Undersøgelse omfatter Bjergarterne fra Paleocænet i dette Ords snævrere Betydning, nemlig fra den Lagserie, der ligger over Danienet og under den tufførende Serie.

Side 10-12 gives en kort Oversigt over tidligere Arbejder vedrørende Paleocænet, for saa vidt disse berører petrografiske Forhold. Den sidste indgaaende Behandling af de paleocæne Bjergarter, der foreligger i Litteraturen, er foretaget af O. B. BøGGILD, der adskiller tre Bjergartsgrupper: 1, den sandede Facies, 2, Kertemindemergelen og 3, det kalkfri Paleocæn og ved Hjælp af Boreprofiler viser, at Bjergarterne i Hovedsagen optræder i den nævnte Orden fra neden og opefter, men at de delvis maa opfattes som Faciesdannelser.

\section{Undersøgelsesmetoden. Forklaring til Tabeller, Profiltegninger og Kurver.}

Undersøgelsesmetoden omtales Side 12-16. De haarde sammenkittede Bjergarter er væsentlig undersøgt som Tyndslib, medens de løsere Sand-, Mergel- og Lerprøver er blevet underkastet en mekanisk Analyse ved Slæmning og Sigtning, hvorefter de enkelte Fraktioner er blevet mineralogisk undersøgt, saavel kvalitativt som kvantitativt. - Alle Kornstørrelsesbetegnelser i Afhandlingen er Diameter i mm.

De mekaniske Analyser. I de mekaniske Analyser er benyttet følgende Fraktionsgrænser: $0,02-0,05-0,1-0,2-0,5-1-2$ o. s. v. $\mathrm{mm}$ i Diameter. Korn under $0,02 \mathrm{~mm}$ betegnes som Slam (mud), Korn over $2 \mathrm{~mm}$ som Grusbestanddele.

De fundne Resultater er angivet i Tabeller, og desuden er Resultaterne angivet grafisk paa forskellig Maade. Hvor der foreligger Prøver fra forskellige Dele af et Profil, er der tegnet skematiske Profiler, der viser den procentuelle Fordeling af Kornstørrelserne i de forskellige Dele af Profilet og derved giver et letfatteligt Indtryk af Bjergarternes vekslende Karakter. Endvidere er Analyserne optegnet i Form af Pyramidediagrammer, hvori Kornstørrelsen er tegnet som Abscisse (i logaritmisk Maalestok) og Procentmængden i Fraktionerne som Ordinat. For at faa Fraktioner, der ækvivalerer hinanden, »Klasser«, er Analyserne ad grafisk Vej omregnet, saaledes at de nye Klassegrænser danner en Kvotientrække med Kvotienten 2 (UdDens Skala). Procentmængden af Korn under $1 / 64 \mathrm{~mm}$ er afsat i en enkelt Klassekolonne.

De kvantitative mineralogiske Analyser er foretaget ved Optælling af Mineralkorn i Slæmmefraktionerne, dog er Kalkindholdet i Reglen bestemt ved kemisk Analyse. Hvor der i Tabellerne er angivet *, er Kalkindholdet 
bestemt ved Optælling af Korn. Ved Kombination af Optællingerne og de mekaniske Analyser har jeg beregnet Fordelingen af de enkelte Komponenter i de forskellige Kornstørrelser, d. v. s. den oprindelige mekaniske Analyse er opdelt i mekaniske Analyser af de enkelte Mineralkomponenter. Fordelingen af de tre vigtigste, mere eller mindre transporterede Komponenter, nemlig Kalkbestanddele, alloktone Bestanddele (væs. Kvarts) og Glaukonit er angivet i Fordelingskurver.

Tabellerne med de kvantitative Analyser indeholder 4 Kolonner: 1, Mineralindholdet i Fraktionerne i Procent; 2, Forholdet mellem de forskellige alloktone Mineraler; 3, Forholdet mellem Glaukonit og Pyrit, og 4, Kornfordelingen beregnet af Optællingerne (Kolonne 1) og den mekaniske Analyse (angivet i Promille).

Fordelingskurverne er fladetro, d. v. s. det Areal, som er begrænset af Kurven, to tilfældigt valgte Ordinater og Abscisseaksen, markerer, hvor mange Procent af vedkommende Mineral der findes i en Fraktion, hvis Over- og Undergrænse er angivet ved Abscisserne til de to valgte Ordinater. Procentangivelserne paa Figuren gælder for Fraktioner, hvori de største Korn er dobbelt saa store som de mindste. Da Kalkindholdet i Prøverne i Reglen er stort i Forhold til de øvrige Bestanddele, er Kurven for Kalken tegnet i halv Maalestok, og Procentangivelsen til venstre gælder for Kalkkurven, den til højre for Glaukonit- og Kvartskurverne. --.- Kalk; _- Glaukonit; ..... alloktone Bestanddele (væsentlig Kvartssand).

Af Kornfordelingstabellerne og Fordelingskurverne fremgaar, at de forskellige Bestanddele kan gruppere sig forskelligt, selv i samme Bjergart. Efter Fordelingen kan skælnes mellem to Hovedtyper, idet Kornene enten kan gruppere sig omkring et Maksimum af Sandstørrelse eller gruppere sig saaledes, at der er større og større Mængder af vedkommende Mineral, jo finere Kornstorrelsen er. I sidste Tilfælde maa Maksimet for vedkommende Mineral findes i Slammet, og man kan saaledes i Bjergartsbeskrivelsen angive, om Bjergarten er en Sandtype eller en Slamtype med Hensyn til vedkommende Mineral. For de alloktone Bestanddeles Vedkommende maa der skælnes mellem alloktont Sand d. v. s. Kvartssand og alloktont Slam, d. v. s. Ler.

Glaukonit-Pyritforholdet. Glaukoniten og Pyriten kan betragtes som Indikatorer for de hydrografiske Forhold, hvorunder Bjergarterne er afsat, idet disse to Mineraler er dannet ved kemisk Virksomhed i Havvandet eller paa Havbunden. Et stort Antal tidligere Undersøgelser har vist, at Glaukonit dannes i Havvand, der indeholder Ilt, Pyrit derimod i meget iltfattigt Vand, en Kendsgerning, som har givet Anledning til, at jeg i denne Afhandling har undersøgt Variationerne i Lagserierne ved Optælling af Procentforholdet mellem Glaukonit og Pyrit. Det har vist sig, at Glaukonit-Pyritforholdet i Forbindelse med Kornfordelingen giver en god Karakteristik af de forskellige Bjergartstyper.

\section{Oversigt over Paleocænets Forekomst i Danmark.}

Kortet Figur 1 Side 8 viser den prækvartære Undergrund i Danmark, saaledes at det stregede Areal angiver Aflejringer ældre end Paleocænet, det prikkede Areal Aflejringer yngre end Paleocænet og de hvide Arealer Steder, hvor Paleocænet er truffet umiddelbart under Kvartæret. Kortet angiver alle de Lokaliteter, som er behandlede i Afhandlingen. En Ring 
med en Prik angiver Dagforekomster eller Udgravninger med faststaaende Paleocæn hvilende paa Underlaget, en Ring: dislocerede Dagforekomster. De rektangulære Tegn angiver Boringer. Heri betegner det hvide Felt Paleocænet, sort over det hvide betegner, at der desuden er fundet Tertiær, yngre end Paleocænet, sort under det hvide, at der er fundet Kridtaflejringer under Paleocænet.

De paleocæne Bjergartstyper er ujævnt fordelt, idet Gronsandsdannelser væsentlig er fundet paa Sjælland, Kertemindemergel i den vestlige Del af Sjælland og paa Fyn, og forskellige Mergelarter i Djursland. Beskrivelsen af Dagforekomsterne falder derfor naturligt i tre Grupper: 1, Lokaliteter paa Sjælland med overvejende Grønsand (København, Lellinge, Tune); 2, Lokaliteter med typisk Kertemindemergel (Kerteminde, Hanerup) og 3, Lokaliteter paa Djursland (Hvalløse, Svejstrup, Ommestrup, Holme og Rugaard).

\section{Beskrivelse af Dagforekomsterne.}

\section{Københavnsomraadet.}

Paleocænet, der er fundet paa 14 Steder i København (se Kortet Fig. 3, Side 19), bestaar her af Grønsandsdannelser, der opad gaar over i mørke, mere lerede Aflejringer. Det hviler overalt paa Kalksandsdannelser fra Danienets Zone D (Kalksand eller Saltholmskalk), og dets nederste Lag er oftest hærdnet til en haard glaukonitisk Kalksten, Grønsandskalk, hvis nederste Del udgøres af et Konglomerat af Danienforsteninger.

Saltholmskalken er i sin Struktur en virkelig Sandsten, hvori Sandskornene er Kalkkorn af organisk Oprindelse. Cementen er en finere eller grovere Mosaik af klar Kalkspat.

Forsteningskonglomeratet, der udgør Paleocænets Bundlag, er en haard Kalksten, opbygget af mere eller mindre rullede og glaukonitiserede Danienforsteninger, glaukonitiserede Kalksandbestanddele og Glaukonitkorn, alt sammenkittet af en krystallinsk Kalkspatmosaik. Rullesten af Saltholmskalk er meget sparsomt til Stede. Glaukonitiseringen af Fossilerne og Kalksandskornene er sket paa den Maade, at Glaukoniten er trængt ind i Porer og Hulheder og har afsat sig der, og videre bredt sig paa Kalkens Bekostning (Tavle 1, Fig. 1). Kalksandskornenes Størrelse stemmer overens med Kornstørrelsen af Kalksandet i de groveste daniske Kalksandsaflejringer, hvilket viser, at de stammer fra disse Lag. Af alloktone Bestanddele findes faa Kvartskorn af lignende Kornstørrelse som Kalksandet. Glaukonit forekommer foruden som Pigment i Kalkkornene - som Korn af samme Kornstørrelse som de øvrige Sandbestanddele. Endvidere findes lidt Pyrit, væsentlig som Pigment i Kalkkornene, og nogle faa ellipsoidiske Koproliter.

Grønsandskalken er af ganske samme Natur som Forsteningskonglomeratet, kun mangler de grove Skalbestanddele, og Indholdet af Glaukonitkorn er noget større. Hovedkornstørrelsen i Grønsandskalken er omkring $0,2 \mathrm{~mm}$.

Særlige Træk findes i Bjergarter fra Larsens Plads og i Blokke fra Lokalmorænen i Nordisk Fjerfabrik i Frihavnen.

Paa Larsens Plads findes et Forsteningskonglomerat med særlige Forhold ved Cementationen, idet Hulrummene mellem de rullede Forsteninger og 
Sandskornene kan være beklædt med en ca. 0,04 mm tyk Zone af traadet Kalkspat, der i visse Dele af Bjergarten gaar over i stalaktitiske Masser og maa antages at være en oolitisk Dannelse (Tavle 1, Fig. 2). Paa denne Zone sidder en Zone af sphærulitisk Kalcedon af omtrent samme Tykkelse, enten som spredte, paasiddende halve Sphæruliter eller som et helt Baand, dannet ved Sammenvoksning af Sphæruliter, men mindre Hulrum kan ogsaa være helt udfyldt af Kalcedon (Tavle 1, Fig. 2 forneden).

Blokke fra Lokalmorænen i Nordisk Fjerfabrik viser Partier, der i høj Grad er pyritiserede. Det kan her vises, at Pyritiseringen er gaaet ud fra Kalkkornene og har bredt sig videre herfra. Glaukonitiseringen er gaaet forud for Pyritiseringen, medens Cementationen med Kalkspat er sket efter denne (Tavle 1, Fig. 3).

Kalkrullestenene i Forsteningskonglomeratet er ofte glaukonitiserede, men stemmer ellers overens med de groveste Typer af Saltholmskalk fra Paleocænets Underlag. Glaukonitiseringen af Rullestenene er sket, efter at de er cementerede af Kalkspat, thi man finder Glaukonit i Form af en Mellemmasse, som omgiver klare Kalkspatkorn, der maa være Cement (Tavle 1, Fig. 5).

Paleocænet ved Vodroffsvej. Ved Vodroffsvej er truffet næsten uhærdnet paleocænt Skalgrus og Grønsand hvilende paa næsten uhærdnet danisk Kalksand. Mineralindholdet i de paleocæne Bjergarter er som i de hærdnede Bjergarter, men Hærdningen viser sig kun ved, at der paa Kalkbestanddelene sidder nydannede Smaakrystaller af Kalkspat. Mellemmassen mellem Sandskornene indeholder bl. a. Glaukonit i Form af en strukturløs eller sliret Mellemmasse (Tavle 1, Fig. 6). Det kan vises, at Mellemmasse-Glaukoniten er dannet samtidig med den pigmentære Glaukonit i Kalkkornene, medens Glaukonitkornene er en lidt ældre Generation, der er mere eller mindre transporteret.

Vestre Gasværk. Bjergarterne fra to Udgravninger fra Johnstrups berømte Lokalitet er undersøgt. En Udgravning fra 1930 indeholdt over Saltholmskalken ca. 0,4 m Grønsandskalk, derover først $3 \mathrm{~m}$ Grønsand med et enkelt Gruslag af Danienforsteninger og, øverst, ca. 0,8 m mere og mere finkornede og lerede Bjergarter. I en Udgravning fra 1931 fandtes 0,3 m Grønsand, derover 0,6 m mere finkornede Overgangsbjergarter og 2,6 m mørke, delvis sandede Mergelarter. Blandt de sidste kan man paavise en Konglomeratstruktur, idet Mergelen indeholder Rullesten af haardere og mere sandet Grønsand (Fig. 7, Side 39). Disse Grønsandsrullesten er petrografisk forskellige fra den Mergel, de ligger i, og der er saaledes Tale om et virkeligt intraformationalt Konglomerat. De undersøgte Prøvers Beliggenhed i Lagserierne fremgaar af Fig. 8, Side $42 \mathrm{og}$ Fig. 9, Side 43. Disse to Figurer viser, at Sandmængden aftager opad, men man kan dog tydeligt erkende to Bjergartstyper, en nedre sandet og en øvre mere leret. Pyramidediagrammerne (Fig. 10, Side 44) viser, at de sandede Bestanddele er velsorterede, og tillige, at Kornstørrelsen af Sandbestanddelene i Grønsandet og Gruset (Prøve 5) er den samme. I de Prøver, der indeholder nævneværdige Mængder af groft Sand og Grus, finder man et særligt sekundært Maksimum, og de grove Bestanddele har en Størrelse, der er ca. 16 Gange Sandets. Dette stemmer overens med en Lov, der er fundet af UdDEN, ifølge hvilken de rullede 
Grusbestanddele i en velsorteret Aflejring er ca. 16 Gange saa store som de Sandbestanddele, der er medført svævende i Vandet.

Mineralindholdet er i alt væsentligt som i de hærdnede Prøver. Kalksand, stammende fra Danienunderlaget, danner en stor Del af Bjergarterne, navnlig af de nederste. Af alloktone Mineraler findes Kvarts, Feldspat og lys Glimmer, samt en ringe Mængde grøn Hornblende, Turmalin, Granat og Zirkon. Glaukonit findes som Korn og som Imprægnation i Kalkbestanddelene. Den imprægnerede Glaukonits meget uregelmæssige Former ses af Tavle 2, Fig. 1, der viser en Sandfraktion behandlet med fortyndet Saltsyre. Pyrit findes i de nedre Prøver som tilfældigt formede Konkretioner, i de øvre Prøver som ganske smaa Kugler, der kan være grupperet i større Konkretioner af trekantet Form eller Skiveform, dannede i Diatomeer. Kokkoliter findes i alle Prøver, men særlig i Prøverne fra Mergelserien. Paleocæne Foraminiferer er tilstede i alle Prøver. Svampenaale findes hyppigst i Mergelen. De kan bestaa af Opal eller være omdannede til Kalcedon eller Pyrit.

Kalksandskornene maa opfattes som en klastisk Bestanddel, der stammer fra Underlaget, og de staar saaledes i Modsætning til de alloktone Bestanddele (Kvarts, Feldspat, Glimmer o. a.). Kalksandet er dog ikke strængt autoktont. Det er omlejret og sorteret og transporteret en kortere Vej end de alloktone Bestanddele. For saadanne Bestanddele, der nok er transporterede, men dog stammer fra et begrænset Omraade mangler Litteraturen en Benævnelse. Jeg foreslaar anvendt Ordet anki-autokton, som skal betegne den omtrentlige men ikke fuldstændige Autoktoni.

De kvantitative Forhold fremgaar af Tabel 3, Side 51 og Fordelingskurverne Fig. 11, Side 53. Karakteristiske Ændringer i Lagserien er fra neden og opad: 1, Raaprøvernes og Slammets Kalkindhold aftager opad (Tabellen Side 49), 2, Mængden af Kvartssand aftager opad, 3, Mængden af alloktont Lerslam tiltager opad og 4, Mængden af Pyrit tiltager opad.

Kornfordelingskurverne viser to Bjergartstyper, nemlig kalkholdigt Grønsand med Kombinationen Kalksand-Kvartssand-Glaukonitsand, og leret Grønsand med Kombinationen Kalksand—Glaukonitsand-Ler.

Sundkrogen. Her er ved Boringer fundet lignende Lag som ved Vestre Gasværk. Ved Hjælp af Kalkanalyser, Bjergartskarakteren og Oplysninger i Borejournalerne er Boringerne kombineret til en Lagserie, vist i Fig. 12, Side 58. Over Saltholmskalken findes her: $0,8 \mathrm{~m}$ Grønsandskalk - 2,5 m Grønsand - 2,8 m mørk Mergel. Den mørke Mergel er meget rig paa Pyrit.

\section{Lellinge.}

Paa Kortet Fig. 13, Side 60 angiver Krydsene de Steder, hvor Grønsandsdannelserne træder i Dagen, $1-4$ angiver Johnstrups Borehuller, og L de Steder, hvor Saltholmskalk (hærdnet Bryozokalk) træder i Dagen.

Bjergarterne fra Lellinge er Grønsandsdannelser, der væsentlig afviger fra Grønsandet fra København ved de sekundære Processer, de har undergaaet. En Prøve fra Paleocænets Bundlag (Johnstrups Boring 3) viser en forholdsvis lidet sorteret og lidet hærdnet Bjergart. Denne og alle de øvrige Bjergarter fra Lellinge indeholder i alt væsentligt de samme Bestanddele som de paleocæne Bjergarter fra København. Afvigende Forhold er, at Kalksandet for en stor Del er Bryozofragmenter, og at Bjergarterne er meget rige paa Svampenaale. Efter de sekundære Forandringer Bjergarterne har undergaaet, 
kan man adskille tre Typer, nemlig 1, Grønsandsten, hvori Svampenaalene for en stor Del er opløste, medens Grundmassen er imprægneret med Kiselsyre, 2, Hornsten, en flintagtig Bjergart, hvori Svampenaalene er omdannet til Kalcedon (Tavle 2, Fig. 3 foroven), hvorefter Forkislingen er skredet videre frem under Dannelse af en flintagtig Kalcedonbjergart (Tavle 2, Fig. 3 forneden) og 3, Grønsandskalk, der er hærdnet af krystallinsk Kalkspat. Svampenaalene har været opløste før Cementeringen, thi man finder Hulrum efter Svampenaale udfyldt af klar krystallinsk Kalkspat (Tavle 2, Fig. 4).

Af løse Prøver er undersøgt 3, nemlig Prøve 1: en Boreprøve fra Johnstrups Boring 3, ca. 1,6 m over Grænsen mod Kridtet; Prøve 2: Prøve af et mørkt leret Lag, som findes mellem Grønsandslagene nær Johnstrups Boring 2, og Prøve 3: løst leret Grønsand over den mørke Mergel. Slemmeanalyser (Tabel 4, Side 67 og Tabel 5, Side 68), Pyramidediagrammer (Fig. 14, Side 69), kvantitative Analyser (Tabel 6, Side 70) og Fordelingskurverne (Fig. 15, Side 71) viser de løse Bjergarters Lighed med dem fra København.

Bjergarterne fra Tune svarer $\mathrm{i}$ alt væsentligt til dem fra Lellinge.

\section{Kertemindemergelen.}

Der er analyseret 2 Prøver fra Kerteminde og 1 fra Hanerup. Kertemindemergelen er en Mergel med yderst faa Korn over 0,02 mm (Tabel 7, Side 75). Kalkbestanddelene er for en stor Del Kokkoliter og Foraminiferer, men hertil kommer en ikke ringe Mængde Kalkslam, der formodentlig er kemisk udfældet. Noget Kalk kan dog stamme fra Kridtunderlaget. Af alloktone Bestanddele findes en Del Ler, samt temmelig faa, fine, sandede Bestanddele (væs. Kvarts, Feldspat og Glimmer). Glaukonit er næsten ikke tilstede medens Pyrit er yderst almindelig. Dette Mineral forekommer altid som Smaakugler med en Diameter af 0,005 - 0,07 mm. Kuglerne er i Reglen forenede i større Konkretioner, der er trekantede eller skiveformede og dannede i Diatomeer (Tavle 2, Fig. 2). De forkislede Bjergarter, der findes som underordnede Lag i Kertemindemergelen, er oftest mere sandede og betydelig rigere paa Glaukonit end Kertemindemergelen. De indeholder desuden rigeligt med Svampenaale. Bjergartsgrundmassen er imprægneret med Kiselsyre og Svampenaalene undertiden omdannet til Kalcedon. De forkislede Bjergarters mere sandede Karakter og større Glaukonitindhold viser, at der i Lagserien findes en vis Faciesveksel, et Forhold, som endnu tydeligere viser sig i Lokaliteter paa Djursland og i nogle af Boringerne.

\section{Hvalløse.}

Dagforekomsten ved Hvalløse indeholder en 3 m mægtig paleocæn Serie, hvilende paa Kokkolitkalk. $1 \mathrm{~m}$ over Paleocænets Undergrænse findes en tydelig Grænse, som viser sig at være en Sedimentationsgrænse, og de paleocæne Aflejringer grupperer sig saaledes i to Serier. I den nedre Serie findes nederst $10-15 \mathrm{~cm}$ Grus, bestaaende af Kalkrullesten, rullede Danienforsteninger og Grønsand, og derover en jævn Overgang gennem Grønsand og finsandet Mergel til en mørkegraa, ret fed Mergel foroven. Over Sedimentationsgrænsen findes lys Mergel, hvis nederste Del er noget sandet, væsentlig med Sandskorn af Glaukonit. De undersøgte Prøvers Beliggenhed fremgaar af Profiltegningen Fig. 18, Side 82.

Slæmmeanalyserne (Tabel 9 og 10, Side 81; Fig. 18, Side 82) og Pyramidediagrammerne (Fig. 19, Side 83) viser i den nedre Serie: 1, aftagende Sandindhold opad; 2, aftagende Maksimalkornstørrelse opad, og 3, tiltagende Sor- 
teringsgrad opad. Sedimentationsgrænsen viser sig ved et Spring i den mekaniske Sammensætning (Fig. 18, Side 82).

Kvantitative Analyser. Ved Hjælp af de kvantitative Analyser og den beregnede Mængde af Kalk i Slammet og Raaprøverne (Side 86) kan det vises, at i den nedre Serie tiltager Mængden af alloktont Lerslam opad, medens Mængden af Kalksand aftager opad. I den øvre Serie aftager Mængden af alloktont Lerslam opad, medens Mængden af Kalkslam tiltager opad. Den nedre Serie viser saaledes Lighedspunkter med Vestre Gasværksserien, medens den øvre forholder sig saaledes, at Bjergarten opad gaar over i en kalkrig Slamfacies, hvori en meget stor Del af Bestanddelene er organisk Kalk (Kokkoliter, Foraminiferer) eller kemisk udfældet Kalkslam.

Fordelingskurverne (Fig. 20, Side 88) viser, at det i de nederste, daarligt sorterede Prøver (Nr. 1 og 2) væsentlig er Kalksandet, der er usorteret, hvorimod Glaukoniten grupperer sig omkring et tydeligt Maksimum af Sandstørrelse. Efterhaanden som Sorteringsgraden i Bjergarterne stiger, faar de forskellige Bestanddele samme Fordeling (Nr. 3). Over Sedimentationsgrænsen findes en Bjergart med Kombinationen Glaukonitsand-Kalkslam-Ler, og Glaukoniten grupperer sig her paa samme Maade som i Prøverne 1 og 2. Denne Bjergart, som passende kunde kaldes Glaukonitmergel, gaar jævnt over i en Slamfacies.

\section{Svejstrup.}

Dagforekomsten ved Svejstrup indeholder en ca. $7 \mathrm{~m}$ mægtig Serie af graa til hvid paleocæn Mergel, hvilende paa Kokkolitkalk. Den nederste Del af Mergelen er lidt sandet, og de nederste $25 \mathrm{~cm}$ indeholder glaukonitiserede Rullesten af Kalksten. De undersøgte Prøvers Beliggenhed fremgaar af Profilet Fig. 21, Side 92, der viser, at Indholdet af Grus- og Sandbestanddele aftager opad i Profilet. Tabel 12, Side 94; Tabel 13, Side 95, og Pyramidediagrammerne (Fig. 22, Side 93) viser, at den nederste Prøve af Mergel med Rullesten er daarligt sorteret, idet Kurven er flad og breder sig over mange Klasser.

De kvantitative Analyser viser, at Glaukonitindholdet er størst forneden, men Pyritmængden tiltager opad, saaledes at den øverste Prøve, hvori Glaukonit og Pyrit kan bestemmes, er udpræget pyritbetonet. Pyriten forekommer paa samme Maade som i Kertemindemergelen. Fordelingskurverne (Fig. 23, Side 97) viser Typer, der svarer til Bjergarterne fra Hvalløses øvre Serie, idet der nederst findes en Facies med Glaukonitsand-Kalkslam-Ler, øverst en Facies, der med Hensyn til alle transporterede Komponenter er en Slamfacies. Sammenholdes dette med de øvrige Bjergartskarakterer, ser man, at Svejstrupseriens Bjergarter danner en Serie med en jævn Overgang fra Glaukonitmergel til Kertemindemergel.

\section{Ommestrup.}

En disloceret Forekomst af Paleocæn ved Ommestrup (se Kortet Fig. 17, Side 79) indeholder Bjergarter, der i Type svarer til dem fra Hvalløse og Svejstrup. Et Profil i Mergelgravens Østvæg er tegnet i Fig. 24, Side 98. Prøverne er: 1, hvidliggul forvitret Mergel; 2, sortgraa fed Mergel; 3, lysegraa lidt sandet Mergel med større Glaukonitkorn; 4, lysegraa Mergel og 5, mørkegraa Mergel. Analyserne tyder paa, at Lag 1 er ældst. Bjergarterne viser lignende Forhold som dem omkring Sedimentationsgrænsen i Hvalløseserien, idet der over en fed Mergel findes en Sedimentationsgrænse og derover Glaukonitmergel, der gaar jævnt over i Kertemindemergel. 


\section{Holme.}

Ved Holme (se Kortet, Fig. 17 Side 79) findes en Mergelgrav, hvori Bjergarterne optræder i tydelig Faciesveksel, idet der skiftevis findes hærdnede, noget sandede, lyse Kalksten og blødere Lag af federe, mørk Mergel. Øverst findes lys Mergel af samme Type som Kertemindemergelen. Side 106 er angivet Forholdet mellem Glaukonit og Pyrit i Bjergarterne, optalt blandt Korn af en Størrelse omkring 0,05 mm, samt Bjergarternes Kalkindhold. Denne Tabel viser, at der er et tydeligt Skifte mellem glaukonitbetonede og pyritbetonede Lag, og det viser sig, at de mest sandede Lag er rigest paa Glaukonit, de lerede paa Pyrit. Resultaterne er optegnet i Profilet Fig. 26, Side 105 saaledes at Glaukonitprocenten er angivet med en fuldt optrukket Linje, Kalkindholdet i Procent ved en stiplet Linie. Forholdene tyder paa, at der findes en Række Sedimentationsserier, der hver begynder med noget sandede, glaukonitholdige Bjergarter og afslutter med lerede, pyritholdige Bjergarter. Forskellighederne giver sig ikke alene til Kende i Bjergarterne, men ogsaa i deres Indhold af Forsteninger, idet de glaukonitbetonede Bjergarter indeholder en temmelig rig Fauna, svarende til den fra Rugaard (Grönwall og Harder 1907), medens de pyritbetonede er næsten fossilfri.

\section{Rugaard.}

At dømme efter Grönwall og Harders Beskrivelse (1907) findes der ved Rugaard lignende Forhold som ved Holme, men Forekomsten med kalkholdigt Paleocæn er nu fuldstændig tilskredet. Lidt sydligere forekommer kalkfri paleocæne Bjergarter i Skredterrasserne. Profilerne er meget smaa og forstyrrede, men man kan dog se, at der findes en lagmæssig Veksel mellem bløde, sandede Lerarter og haarde, forkislede Bjergarter. Der er foretaget en mekanisk Analyse af en Prøve af Leret, og de haarde Bjergarter er undersøgt som Tyndslib.

Det graa sandede Ler (Tabel 17, Side 108 og Tabel 18, Side 109; Fig. 27, Side 109). Prøven er sandet Ler, hvori de sandede Bestanddele er grupperet om et udpræget Maksimum. Bjergarten er mere sandet end de paleocæne Mergelbjergarter i de nærliggende Lokaliteter.

Mineralindholdet er typisk paleocænt. Af Organismerester er Svampenaale temmelig almindelige, Radiolarer temmelig sjældne.

Den kvantitative Analyse (Tabel 19, Side 110) viser, at de alloktone Bestanddele udgør Hovedmassen af de sandede Bestanddele. Resten er væsentlig Organismerester (Svampenaale o. a.) og Glaukonit. Prøven er udpræget glaukonitbetonet. Fordelingskurverne (Fig. 28, Side 110) viser, at Kvartssandet og Glaukoniten har samme Fordeling.

Tyndslib af de hærdnede Prøver viser, at Bjergarterne er Sandsten, hvori de sandede Bestanddele (kantede Kvartskorn, Glaukonitkorn og Svampenaale) ligger temmelig spredt $\mathrm{i}$ en fin, brunlig, forkislet Grundmasse (Tavle 2, Fig. 6).

Det karakteristiske for Rugaardbjergarterne er, at Prøverne er kalkfri eller næsten kalkfri, glaukonitbetonede, og rige paa alloktont Sand. Forkislingsforhold og Indholdet af Mineraler og Organismer viser, at de er paleocæne, men deres Stilling i Lagserien kan ikke ses af Rugaardforekomsten. Imidlertid finder man i Boringer Bjergarter med samme Karakterer i Paleocænets øverste Del. 


\section{Boringer.}

Prøverne fra et Antal vigtigere Boringer ned i eller igennem Paleocænet er undersøgt for derved at skaffe et Indtryk af Paleocænets forskellige Udvikling i de forskellige Dele af Landet. Da Prøvematerialet kan være ret mangelfuldt, er der ikke lagt Vægt paa Fastsættelsen af bestemte Grænser for de forskellige Bjergartstyper, men paa en Fremstilling af de vigtigste Variationer i Bjergartskarakteren i de forskellige Dele af Lagserien. De vigtigste variable Faktorer i de paleocæne Bjergarter er 1, Sandindholdet, 2, Kalkindholdet og 3, Forholdet mellem Glaukonit og Pyrit.

De Bestanddele, der gør Bjergarterne sandede, er i de nedre Dele af Lagserien overvejende Kalksand, mere underordnet Glaukonitsand, medens Kvartssand aldrig er paavist i større Mængde. Større Mængde af Kvartssand i de nedre Prøver synes kun at findes i Prøver, der er forurenede at kvartært Materiale. I den øvre Del af Lagserien findes aldrig Kalksand af Betydning, og Hovedmængden af Sandskornene er Kvarts og Glaukonit (sml. Rugaard).

Variationerne i Kalkindholdet staar i Forbindelse med Indholdet af Materiale, der stammer fra nedbrudte daniske Kalkaflejringer, dels Kalksand, dels Kalkslam, endvidere med Indholdet af organiske Kalkbestanddele (Kokkoliter, Foraminiferer) og kemisk udfældet Kalkslam (som i Kertemindemergelen). I de forkislede Bjergarter er Kalkindholdet betydelig lavere end i de tilsvarende uforkislede Bjergarter.

Forholdet mellem Glaukonit og Pyrit, der har Betydning for Forstaaelsen af de hydrografiske Forhold, hvorunder Bjergarterne er dannede, er optalt blandt Korn med en Størrelse omkring $0,05 \mathrm{~mm}$. Pyriten forekommer langt overvejende paa samme Maade som i Kertemindemergelen, d. v. s. som Smaakugler, der kan være samlede i Konkretioner, dannede i Diatomeer.

Boreprofilerne er tegnet efter samme Princip som Holmeserien Fig. 26, Side 105. Boringen er altsaa tegnet som en Kolonne, der skal opfattes som et Koordinatsystem, hvori Ordinaten viser Prøvernes Beliggenhed i Boringen, medens Abscissen viser Kalkindholdet (ved en stiplet Linje) og Glaukonitindholdet (ved en fuldt optrukket Linje). Venstre Side af Kolonnen angiver $0 \%$, højre Side $100 \%$. Sandindholdet markeres ved en mere eller mindre prikket Signatur. Den Dybde, hvori Prøven er taget, er markeret ved en Tværstreg, der er fuldt optrukket, hvis Prøven er mærket med en enkelt Dybde, stiplet, hvis Prøven stammer fra et Dybdeinterval. Hvis det sidste er Tilfældet, er Dybden angivet midt i Intervallet. - Et skraveret Areal forneden i Boreprofilet angiver Kridtaflejringer (B Bryozokalk, C Kokkolitkalk, LS Kalksand). Et krydsskraveret Areal foroven angiver eocæne Bjergarter (væsentlig den tufførende Serie). De vigtigste af Boringerne er tegnet i Fig. 29-32, Side 136-139.

De Resultater, Studiet af Boringerne har ført til, kan sammenfattes i følgende Punkter:

1. Mægtigheden varierer, saaledes at man har en ringe Mægtighed (20$30 \mathrm{~m}$ ) i Midtjylland og i Syddanmark, men en meget større Mægtighed paa Sjælland, Fyn og Samsø (op over $150 \mathrm{~m}$ paa Sjælland).

2. De Bjergarter, der er rige paa Kalksand, findes væsentlig paa Sjælland, og de er altid rige paa Glaukonit.

3. Den paleocæne Lagserie begynder altid forneden med kalkholdige Bjergarter og gaar over i kalkfri Bjergarter foroven. En Vekslen mellem kalkhol- 
dige og kalkfri Bjergarter kan findes, men oftest skyldes et lavt Kalkindhold i den kalkholdige Serie Forkisling af Bjergarterne.

4. I det kalkholdige Paleocæn paa Sjælland er fundet en betydelig Faciesveksel mellem glaukonitbetonede, oftest sandede, og pyritbetonede, lerede Bjergarter (Fig. 31, Side 138). Den kalkfri Facies er derimod næsten altid rig paa Glaukonit.

5. Grænsen mellem Paleocæn og Eocæn viser sig ved en pludselig Overgang fra glaukonitrige til pyritrige Bjergarter (Fig. 32, Side 139).

6. I Egnen omkring Korsør-Nyborg har den pyritbetonede Mergel sin største Betydning og danner endog Paleocænets Bundlag. Jo længere man fjerner sig fra denne Egn, des større Rolle spiller de glaukonitbetonede Bjergarter, paa Sjælland Grønsand i stor Mægtighed, paa Djursland Glaukonitmergel, og i Midtjylland og Syddanmark lidet karakteristiske Bjergarter, der er svagt sandede eller lerede, med et ringe Kalkindhold og oftest mere Glaukonit end Pyrit.

\section{Undersøgelsernes Resultater.}

Side 139-150 sammenfattes Undersøgelserne fra de forskellige Lokaliteter og Boringer. Dette Kapitel, der samler Resultaterne til et Helhedsbillede, gengives $\mathrm{i}$ det følgende $\mathrm{i}$ væsentlig uforandret Form.

\section{Paleocænets Begrænsning, underliggende og overliggende Bjergarter.}

Paleocænets Underlag udgøres af Kalkbjergarter fra Danienet, oftest fra Danienets øverste Zone. Bjergarten er nogle Steder Bryozokalk, andre Steder Kalksand og atter andre Steder finkornede Kalkbjergarter (Kokkolitkalk). Ved Gedser er Underlaget muligvis Skrivekridt.

Underlagets Beskaffenhed kan være forskelligt selv paa Lokaliteter, der ligger meget nær ved hinanden. I København ser man saaledes, at Paleocænet ved Sydhavnen hviler paa en finkornet Kalksandsbjergart (Foraminiferkalk), ved Vodroffsvej derimod paa mindst $2 \mathrm{~m}$ groft Kalksand. Der maa altsaa være nedbrudt ret mægtige Kalksandsdannelser ved Paleocænets Begyndelse. De nedbrudte Kalksandsmængder indgaar i det paleocæne Grønsand, og dette er Aarsagen til, at det sandede Paleocæn har en betydelig Mægtighed. I Egnen omkring Køge (Lellinge) finder man, at Paleocænet hviler paa Bryozofragmentkalk, men i Nærheden findes Kalksandsdannelser, der er yngre end denne Kalk, og det sandede Paleocæns Mægtighed viser, at der ogsaa her er nedbrudt store Mængder af daniske Bjergarter. Ved Hvalløse og Svejstrup finder man Rullesten af Foraminiferkalk, medens Underlaget bestaar af Kokkolitkalk, og man finder store Mængder af Ceratotrochus milthersi paa sekundært Leje i Paleocænets Bundlag ved Hvalløse, hvorimod denne Forstening ikke findes i de omgivende Bjergarter. Her har man atter et Bevis for, at store Mængder Danien er nedbrudt ved den paleocæne Transgression.

Slutningen af Danientiden er en Hævningsperiode, hvori der aflejres Kalksand og Kalkslamdannelser, som simpelthen er Derivater af tidligere afsatte daniske Bjergarter. Med Paleocæn-Transgressionen indledes nye Naturforhold, og der sker en Tilførsel af terrigent Materiale til Danmark. Grænsen mellem Danien og Paleocæn markeres saaledes ved en gennemgribende Diskordans (der kan forfølges til Nordtyskland og til Skaane) og ved Ændringer i 
Naturforholdene og Karakteren af de afsatte Sedimenter. Det er derfor ogsaa naturligt at sætte Grænsen mellem Kridt og Tertiær ved Paleocænets Begyndelse.

Paleocænets øvre Begrænsning kendes kun fra Boringer, og da Lagene omkring Grænsen mellem Paleocæn og Eocæn er fossilfri, maa man benytte Bjergartskaraktererne til Fastsættelsen af Grænsen.

De kalkfri Bjergarter, som er regnede til Paleocænet, er i mineralogisk Henseende ganske analoge med de kalkholdige. Det er graat, lidt sandet Ler eller leret Sand, aldrig meget fede Lerarter. Paleocæne Træk er: 1, Pyritens Forekomst som Smaakugler, der er samlede i Konkretioner af Form som Diatomeer, 2, Tilstedeværelsen af stavformede Svampenaale af samme Type som i det øvrige Paleocæn og i samme Bevaringstilstand, 3, Tilstedeværelsen af samme Typer af Radiolarer, samt 4, det Forhold, at Bjergarterne ofte er forkislede. Glaukonitkorn er i det kalkfri Paleocæn meget hyppigt tilstede.

Over det kalkfri Paleocæn finder man en Serie af Bjergarter, der er karakteriseret ved at indeholde Lag af vulkansk Aske (dog meget lidt i den nederste Del) og derover rødt og graat Plastisk Ler.

Den askeførende Series Bjergarter er meget varierende. I Limfjordsegnene bestaar de af Moler, nederst dog af meget fedt, grønligt eller gulliggraat Ler. Ved andre Dagforekomster findes omdannet Moler i Faciesveksel med fedt, mørkegraat Ler. Ved Boringer er enkelte Steder fundet omdannet Moler (f. Eks. Galten), men overvejende en Serie af meget fede Lerarter, oftest af graalige Farver. Undertiden kan Bjergarterne næppe skælnes fra det typiske graa eller grønlige Plastiske Ler, men oftest er de af samme Type som det graa Ler fra Dagforekomsterne udenfor Limfjordsegnene. Det karakteristiske for disse Bjergarter er, at de ved Udrøring med Vand faar en meget slimet Konsistens, og at de indeholder store Mængder af Opal og Pyrit. Pyriten findes som Smaakugler og som Pseudomorfose efter Diatomeer og Radiolarer (Pyriten gengiver i alle Detailler Kiselorganismernes Struktur, i Modsætning til i Kertemindemergelen, hvor Diatomeernes Hulrum er fyldt med Pyritkugler). Forkislede Lag findes ikke i den askeførende Serie.

Bjergarterne fra den askeførende Serie er efter det anførte meget forskellige fra de paleocæne Bjergarter, og i Boringerne viser Grænsen mellem Paleocænet og Eocænet sig baade i Bjergartskarakteren og i Glaukonitindholdet (Fig. 32 Side 139). Grænsen mellem Paleocænet og Eocænet markeres ved en pludselig Overgang fra glaukonitbetonede, lidt sandede til pyritbetonede, meget fede Lerarter. Denne Forskel i Glaukonit- og Pyritindhold tyder paa pludselige Forandringer i de hydrografiske Forhold paa Overgangen mellem Paleocænet og Eocænet. Det er rimeligt at tænke sig, at de Uroligheder, som bevirker Fremkomsten af vulkansk Virksomhed, ogsaa har ændret Havets geografiske Forhold, og dermed de hydrografiske Forhold, saaledes at Bjergartskarakteren i Eocænet bliver en anden end i Paleocænet. Det Forhold, at Bjergarterne fra den askeførende Serie er meget forskellige fra de paleocæne Bjergarter, men delvis identiske med det eocæne Plastiske Ler, viser, at det er naturligt at henregne den askeførende Serie til Eocænet.

\section{De paleocæne Bjergarter.}

Mineralindholdet. Efter Oprindelsen maa skælnes mellem følgende Grupper: 1, Materiale, der stammer fra Paleocænets Underlag, nedbrudt ved $\mathrm{Pa}$ leocænhavets Transgression; 2, de alloktone, klastiske Bestanddele; 3, Be- 
standdele, dannede ved kemiske Processer i Havet eller paa Havbunden; 4, de organiske Bestanddele (Indholdet af Mikroorganismer); 5, Bestanddele dannede ved Cementation, Forvitring o. lign.

1) Materiale, der stammer fra Paleocænets Underlag. Paleocænet hviler overalt i Danmark paa Kalkbjergarter, og en stor Del af Kalkbestanddelene i Paleocænet stammer fra nedbrudte Kalksten. Dette gælder først og fremmest Kalksandet og en stor Del af Kalkslammet i de nederste Dele af Paleocænet, samt Kalkrullesten og glaukonitiserede Danienforsteninger fra Konglomeratlagene. Mængden af disse Bestanddele er størst umiddelbart over Kridtet, og Mængden aftager opad.

Forekomsten af Kalkrullesten, der ikke er petrografisk overensstemmende med Underlagets Kalk (København, Hvalløse, Svejstrup), viser, at Kalkbestanddelene i det nedre Paleocæn ikke er autoktone i dette Ords snævreste Betydning. Dog stammer de fra et begrænset Omraade, og det vil være uheldigt at benævne dem alloktone. Derfor indføres et nyt Begreb »anki-autokton« som Betegnelse for Bestanddele, der stammer fra et begrænset Omraade, hvorfra de kun er transporteret en kortere Vej, saaledes at de er »omtrent, men ikke ganske" autoktone.

Til de anki-autoktone Bestanddele i Paleocænet hører, foruden Kalkbestanddele, muligvis en ringe Del af Kvartskornene, som kan stamme fra Danienets Kalksten. Anki-autokton er endvidere den Glaukonit, der forekommer som afrundede eller loberede, glatrandede Korn.

2) De alloktone, klastiske Bestanddele er dels Sandbestanddele, dels Lerslam. De spiller ingen støre Rolle i Paleocænets Bundlag, hvor de ankiautoktone Bestanddele dominerer, men tiltager stort set i Mængde opad i Lagserien for at udgøre Hovedmængden af Bjergarten i den kalkfri Facies.

De kvantitative Optællinger viser, at de alloktone Bestanddele langt overvejende er Kvarts, hvortil kommer nogle faa Procent Feldspat (Ortoklas, Mikroklin og underordnet Plagioklaser) og lys Glimmer, væsentlig i de fineste Sandfraktioner. Af accessoriske Bestanddele er fundet grøn Hornblende, Turmalin, Zirkon, Granat og Titanit.

3) De Bestanddele, der er dannede ved kemiske Processer i Havet eller paa Havbunden, er Glaukonit, Pyrit, Kalkspat og Jernspat.

Glaukoniten optræder

1, som afrundede eller loberede glatrandede Korn, der oftest er ganske rene eller indeholder fint fordelt Pyrit.

2, som pigmentær Glaukonit, der er opstaaet paa Bekostning af organiske Kalkdele. Ved Hvalløse er fundet Glaukonitmasser, der saavel i Form som i optisk Orientering af Smaakrystallerne er i Overensstemmelse med den Kalk, de har fortrængt.

3, som pigmentær Glaukonit, der er trængt ind mellem Korn uden at opløse andre Bestanddele. Hertil hører f. Eks. Glaukonit i Sprækker i Kvartskorn og mellem Kvartskorn i Kvartsitfragmenter. Endvidere Glaukonit i en Del af de glaukonitiserede Rullesten.

4, som Glaukonitslam, der i de uhærdnede Bjergarter findes mellem Sandbestanddelene paa en saadan Maade, at det gaar over i Bjergarternes kalkholdige Lerslam.

Iagttagelser paa Tyndslib viser, at den pigmentære Glaukonit og Glaukonitslammet, der findes i Bjergarternes Grundmasse, gaar over i hinanden og saaledes maa være dannet samtidigt. Dette Forhold viser med stor Tydelig- 
hed, at Glaukonit i sin oprindelige, primære Form findes som udifferentieret Glaukonitsubstans, der kan optræde overalt i de glaukonitførende Aflejringer.

Den Anskuelse, at Glaukonit dannes som Kolloid, er nu almindelig anerkendt (Caspari 1910; Hummel 1922; Berz 1921; Hadding 1932). De fleste Forskere antager, at den kolloidale Glaukonit med Tiden gaar over i krystallinsk Form, og man ser den Anskuelse fremsat, at al recent Glaukonit er kolloidal, og først den fossile kan være krystallinsk (Hummel 1922). I saa Fald skulde der forløbe lange Tidsrum mellem Dannelsen og Krystallisationen. Herimod taler den Maade, hvorpaa Glaukoniten kan forekomme ved Hvalløse som Pseudomorfose efter Kalk, saaledes at Glaukonitens optiske Orientering er overensstemmende med Kalkens. Naar Glaukoniten har erstattet Kalken, og Glaukonitdelene ligger orienterede, maa Glaukoniten samtidig med sin Afsætning være krystalliseret. Denne hurtige Krystallisation er dog ikke det normale, thi langt den største Mængde Glaukonit viser den fine Aggregatstruktur, som antages at hænge sammen med Omdannelsen fra Gel til krystallinsk Glaukonit.

Det er paavist i Afhandlingen, at Glaukonitkornene ved deres Farve kan adskilles fra andre Glaukonitmasser, som de forekommer sammen med, og at disse Korn maa være ældre end den pigmentære Glaukonit og Glaukonitslammet. Glaukonitkornene maa saaledes findes paa sekundært Leje i Aflejringerne. Dette betyder ikke, at der er stor Forskel i Dannelsestid eller stor Afstand mellem Dannelsessted og Afsætningssted. Tværtimod viser Kornenes pludselige Optræden i stor Mængde sammen med Glaukonitslammet og Glaukonitpigmentet, at Glaukonitkornene hører sammen med den øvrige Glaukonit, blot er der foregaaet en Proces, hvorved der er dannet Korn af Sandstørrelse. Berzs Antagelse, at saadanne Korn dannes ved Sammenflokning af meget fine svævende Glaukonitfnug, synes at have Sandsynligheden for sig (BERz 1921). Forskellen mellem Glaukonitkornene og den pigmentære Glaukonit og Slammet bliver da den, at de sidste Typer er afsat i deres oprindelige Form, medens Kornene er dannede af Glaukoniten ved Bølgernes Bevægelser. Kornene vil da opføre sig som klastiske Bestanddele og aflejres nærmere ved, eller længere borte fra Dannelsesstedet.

Da Glaukonitkornene er noget transporterede, knytter der sig stor Interesse til en Undersøgelse af deres Kornstørrelse i Forhold til de øvrige transporterede Komponenter i Sedimenterne. Det har her vist sig, at Glaukonitkornene ikke altid har samme Kornstørrelse som de øvrige Bestanddele, som det tidligere er hævdet (CAyeux, Berz). En Sammenligning mellem Bjergartstyperne og deres Stilling i Lagserierne har vist, at Glaukonitkornenes Størrelse afhænger af Aflejringernes Sorteringsgrad og Vandbevægelsernes Intensitet. For disse Forhold kan opstilles følgende Regler:

I usorterede eller lidet sorterede Sedimenter optræder Glaukoniten i en Hovedkornstørrelse, der er betinget af Bevægelserne i de Vandlag, hvori Glaukoniten udfældes, ikke af Bevægelserne ved Havbunden, hvor Glaukoniten afsættes. Derfor finder man i saadanne Sedimenter en særlig Gruppering af Glaukonitkornene, medens de andre Komponenters Kornstørrelse er uafhængig af Glaukonitens.

I sorterede Sedimenter sorteres Glaukonitkornene sammen med de øvrige Komponenter. Derfor finder man i de sorterede Bjergarter samme Fordelingsforhold for Glaukoniten og de øvrige Komponenter. 
Pyriten optræder lidt forskelligt i de pyritbetonede og de glaukonitbetonede Bjergarter.

I de pyritbetonede Bjergarter, d. v. s. de, der er dannet i iltfattigt Medium, forekommer Pyriten væsentlig som Konkretioner, dannede af ganske smaa kugleformede Konkretioner, ligesom Svovljernet i Sortehavet (Androussow 1897; Ussing i Victor Madsen 1902). Ofte viser Konkretionerne ved deres Form, at de er dannede i Diatomeer. Denne Form for Pyrit maa være dannet i det reducerende Havvand og i nøje Tilknytning til Sedimentafsætningen.

I de glaukonitrigeste Bjergarter har Pyritmasserne oftest en uregelmæssig Form. Pyriten kan her være dannet paa Bekostning af Glaukonit eller Kalk, og ved videre Konkretionsdannelse kan Pyriten senere brede sig i Mellemmassen mellem Kornene. Alle Iagttagelser viser, at Pyriten i disse Bjergarter er dannet efter Glaukoniten, men før Cementeringen af Bjergarterne. Af Murray \& Irvines Undersøgelser (1895) fremgaar det, at Iltmængden paa Havbunden aftager, saa snart man kommer ned under Bundaflejringernes Overflade. Man kan derfor antage, at Pyriten i de paleocæne, glaukonitbetonede Bjergarter er dannet, saa snart den paagældende Sedimentmasse er blevet dækket af senere afsat Materiale.

Kalkspat. Forekomsten af yderst fine Kalkspatkrystaller i Slammet af Kertemindemergelen tyder paa, at der er sket en kemisk Udfældning af Kalkspat, og jeg finder det sandsynligt, at en stor Del af Kalkslammet i den paleocæene Mergel er dannet ved kemisk Udfældning. Denne Antagelse støttes ogsaa paa, at der i Paleocænet er aflejret en over $100 \mathrm{~m}$ mægtig ensartet Mergelserie med Kalkslam, hvoraf kun en ringe Del kan bestemmes som organisk eller anki-autokton.

Jernspat forekommer i ringe Mængde i enkelte Prøver som Smaakrystaller.

4) De organiske Bestanddele (Mikroorganismerne).

Kokkoliter findes i temmelig ringe Mængde i de stærkt sandede Aflejringer, men er meget hyppige i Mergelaflejringerne. Diat o meer forekommer temmelig sjældent i de sandede Aflejringer; men i Mergelaflejringerne, særlig i Kertemindemergelen, forekommer trekantede og skiveformede Typer i stor Mængde. Yderst sjældent finder man Skallens Opalsubstans bevaret, oftest er den oprindelige Skal opløst, og kun Formen af Pyritkonkretionerne viser, hvor hyppige Diatomeerne har været. Foraminiferer er hyppige i alle kalkholdige paleocæne Aflejringer. Radiolarer forekommer i de fleste paleocæne Bjergarter. De er altid temmelig sjældent til Stede, hyppigst i det kalkfri Paleocæn. Kiselsvampe er almindelige i alle Dele af Lagserien, sjældnest i Kertemindemergelen. Svampenaalene er i Reglen ophobede i særlige Lag, der senere er forkislede. De er bevarede som Opal eller Kalcedon.

5) Bestanddele, dannede ved Cementation, Forvitring o. lign. De paleocæne Bjergarter kan være cementerede af Kalkspat eller af Opal eller Kalcedon.

Cementationen med Kalkspat gaar ud fra Kalkkornene i Bjergarten, saaledes at der paalejres Kalkspatkrystaller, der er i optisk Overensstemmelse med den indenfor liggende Del af Kalkkornet, og ved videre Vækst opstaar der en Mosaik, der er finere eller grovere, alt eftersom Cementationen gaar ud fra mange fine Korn eller kun fra de grovere Korn. - Dannelsen af en oolitisk Kalkspatzone i Hulrummene mellem Kalkkornene er iagttaget i et enkelt Tilfælde (København). 
Cementation med Opal er meget almindelig i Paleocænet og træffes i alle Niveauer af Lagserien. Den viser sig ved, at Bjergarternes Grundmasse er ganske imprægneret med Opal. Ofte er der sket en videre Udvikling af Forkislingen, der viser sig ved, at der er sket en Opløsning af Kalkspatbestanddele, og Opal er traadt i Stedet (visse Hornsten i Mergelserien). Opalsubstansen maa stamme fra opløste Kiselorganismer, dels Svampenaale, dels Diatomeer, hvis Opalsubstans næsten altid er forsvundet.

Dannelsen af Kalcedon. Kalcedon dannes væsentlig ved Udkrystallisation af Opal. Saaledes er det vist, at Kalcedondannelsen oftest begynder med, at Svampenaale omdannes til Kalcedon, og fra den her dannede Kalcedon sker der ved videre Vækst en Paalejring af stalaktitisk Kalcedon, indtil der tilsidst kan være dannet en ganske flintagtig Masse, hvori man kan skælne Svampenaalenes Hulhed og Rester af Kalkkorn. - I en Prøve af Grønsand fra København er paavist en Zonedannelse af stalaktitisk Kalcedon i Hulrummene mellem Kalkkornene.

Forvitringsprocesserne. De forvitrede Bjergartsprøver har i Reglen en mere gullig Farve end de friske, et Forhold, som skyldes Dannelsen af Brunjernsten. Pyriten kan være forvitret til Brunjernsten, og Glaukoniten til Brunjernsten og Opal (se Tabellen Side 101). Kornenes oprindelige Form er i Reglen bevaret efter Forvitringen. Nydannede Gipskrystaller optræder ofte i ringe Mængde sammen med de forvitrede Bjergarter.

\section{De mekaniske Analyser.}

En Del Forhold, som staar i Forbindelse med Afsætningen af Sedimenterne og Sorteringsprocesserne, giver sig til Kende i de mekaniske Analyser. I Lagserierne viser der sig saaledes karakteristiske Andringer fra neden og opad, nemlig: 1, faldende Sandmængde og stigende Slammængde, 2, faldende Kornstørrelse af de sandede Bestanddele og 3, stigende Sortering af Materialet. Det sidste Forhold viser sig klarest i Pyramidediagrammerne fra Hvalløse.

De faa Prøver, der indeholder Grusbestanddele, maa henregnes til to Typer efter Sorteringen.

Skalgruset og de øvrige Prøver med Grusbestanddele fra Vestre Gasværksserien hører til i en Aflejring af velsorterede Bjergarter og stammer fra Lag, der ligger noget over Sedimentationsseriens Bund. I disse Prøver grupperer Sandbestanddelene sig om en Kornstørrelse, der er af samme Størrelse som i de over- og underliggende Lag, medens Grusbestanddelene grupperer sig om en Kornstørrelse, der er ca. 16 Gange Sandbestanddelenes Diameter. Bestanddelene følger saaledes Uddens Transportlov om Forholdet mellem Størrelsen af suspenderet og rullet Materiale i velsorterede Aflejringer (J. A. UDDEN 1914 S. 737). I Modsætning til det velsorterede Grus fra Vestre Gasværk staar Bundaflejringerne fra Hvalløse og Svejstrup. Disse Bjergarter har flade, brede Pyramidediagrammer, og Afstanden mellem Grusets og Sandets Maximer er øjensynlig tilfældig. Saadanne daarligt sorterede Bjergarter synes at være karakteristiske for Transgressionens Bundlag. Forholdet maa forklares ved, at de eroderende og transporterende Virksomheder ved Transgressionens Begyndelse foregaar saa hurtigt, at Uligevægten viser sig i det afsatte Sediment. Først et Stykke oppe i Lagserien indtræder Ligevægt mellem de eroderende Kræfter og Afsætningen af Sediment, og Bjergarten opnaar en højere Sorteringsgrad. 


\section{Sedimenttyper.}

Ved Hjælp af de mekaniske og kvantitative mineralogiske Analyser kan skælnes mellem forskellige Bjergartstyper, der paa lovmæssig Maade gaar over i hinanden.

Adskillelsen af Bjergartstyperne sker i første Række paa Grundlag af Glaukonit- og Pyritindholdet og efter de transporterede Komponenters Kornstørrelse, om de væsentlig findes som Sand eller som Slam. Man kan saaledes adskille følgende Typer:

1. Kalkholdigt Grønsand. Det typiske paleocæne Grønsand er karakteriseret ved at indeholde betydelige Mængder Kalksand, rigeligt Glaukonit af Sandstørrelse og oftest kun ganske lidt terrigent Sand. I Almindelighed er de tre Komponenter sorterede omkring samme Maksimum, dog er de Grønsandsaflejringer, der findes lige over Kridtunderlaget, i mindre Grad sorterede. Rullede Danienforsteninger og Danienkalkrullesten er væsentlig knyttet til Bundlaget. Langt den største Del af Kalken er anki-autokton. Pyrit er i Reglen kun sparsomt tilstede.

2. Leret Grønsand. Det lerede Grønsand er karakteriseret ved at indeholde Kalksand og Glaukonitsand, sorteret i samme Kornstørrelse, samt en større Mængde Slam, der for en stor Del er Ler. Pyrit, der især forekommer paa samme Maade som i de intermediære og pyritbetonede Bjergarter, er hyppigere end i Grønsandet.

3. Glaukonitmergel. Denne Facies er en ekstremt glaukonitbetonet Facies, der af grovere Bestanddele væsentlig indeholder Glaukonitkorn, grupperet om et særligt Maksimum af Sandstørrelse. Af Kalk og alloktone, klastiske Komponenter findes væsentlig Slam, og hertil kommer nogle faa fine sandede Bestanddele, der grupperer sig med større og større Mængde jo finere Kornstørrelsen er. Bjergarten er saaledes en Mergeltype, der foruden Kalkslam og Ler indeholder anki-autoktont Glaukonitsand.

4. Intermediær Mergel. En Del Bjergartsprøver indeholder overhovedet ingen grovere Sandpartikler, kun Slam og fine Korn af Kalk, Glaukonit og terrigent Materiale. En betydelig Del af Kalken er organisk (Kokkoliter, Foraminiferer) eller kemisk udfældet. Bjergarterne indeholder en hel Del Pyrit, som forekommer paa samme Maade som i Kertemindemergelen. Bjergarten er med Hensyn til alle Komponenter en Slambjergart, som danner Overgangen fra de glaukonitbetonede Facies til den typiske Kertemindemergel.

5. Kertemindemergel. Kertemindemergelen er den ekstremt pyritbetonede Mergelfacies, der kun indeholder yderst faa sandede Bestanddele. Hovedmængden af Bjergarten er Kalkslam og Ler, og hertil kommer en betydelig Mængde Pyrit, der forekommer som Smaakugler, ofte samlede i større Konkretioner, der er trekantede eller skiveformede og er dannede i Diatomeer. En stor Del af Kalken er organisk (Kokkoliter, Foraminiferer) eller kemisk udfældet. Glaukonit mangler eller er yderst sjælden.

6. Kalkfri Grønsand. Den eneste analyserede kalkfri Bjergart (Rugaard) maa betegnes som kalkfri Grønsand. Den er karakteriseret ved at indeholde velsorteret Sand foruden en Del Ler. Sandet er dels Kvartssand, dels Glaukonit. Pyrit er ikke særlig almindelig. I Boringer er lignende Typer gentagne Gange fundet over Paleocænets kalkholdige Bjergarter.

7. Kalkfrit Ler. De mere lerede, kalkfri, paleocæne Bjergarter er kun fundet ved Boringer. Foruden Ler indeholder de kun fint Sand, dels Kvarts- 
korn, dels Glaukonitkorn. Pyrit af samme Form som i Kertemindemergelen er ofte hyppigt til Stede, men i Reglen findes der dog mindre Pyrit end Glaukonit.

\section{Lagserier og Faciesforhold.}

I de enkelte Sedimentationsserier sker der lovmæssigt bestemte Andringer i Bjergartskarakteren fra Seriens Bund til dens Top. Disse typiske Ændringer er i den nedre og mellemste Del af den paleocæne Lagserie følgende:

1) Overgang fra Bjergarter med Kalksand til Bjergarter med Kalkslam.

2) Overgang fra klastiske Bjergarter til organogene og kemisk afsatte Bjergarter.

3) Overgang fra glaukonitrige til pyritrige Bjergarter.

I det store og hele betegner disse Andringer Overgangen fra Bjergarter dannede i bevæget, iltholdigt Vand til Bjergarter dannede i stillestaaende, iltfattigt Vand. Paa Grund af Endringer i Erosionsforhold og Vandbevægelser synes et betydeligt Antal af saadanne Serier at være udviklet, saaledes at de forskellige Bjergarter optræder i Faciesveksel med hinanden.

I den øverste Del af den paleocæne Lagserie sker der en Overgang til lidt sandede, glaukonitholdige, kalkfri Bjergarter.

Ser man bort fra den Faciesveksel, der skyldes mindre Ændringer i Erosionen og Vandbevægelserne, ser man, at Bjergarterne i den paleocæne Lagserie følger efter hinanden i følgende Orden:

$\left.\begin{array}{rl}\text { Kalkholdigt Grønsand } \rightarrow & \text { Leret Grønsand } \\ & \text { Glaukonitmergel }\end{array}\right\}$ Intermediær Mergel $\rightarrow$ Kertemindemergel $\rightarrow$ Intermediær Mergel $\left\{\begin{array}{l}\text { Kalkfri Grønsand } \\ \text { Kalkfrit Ler }\end{array}\right.$

Lagseriens Udvikling i de forskellige Dele af Danmark staar i Forbindelse med Karakteren af Underlaget og med de hydrografiske Forhold.

Straks ved Paleocæn-Transgressionens Begyndelse har der været forskellige hydrografiske Forhold i forskellige Egne, thi medens Lagserien sædvanligvis begynder med glaukonitbetonede Bjergarter, begynder den i Egnen omkring Korsør-Nyborg med pyritbetonede Bjergarter.

Bjergarternes Forhold til Underlaget er forskelligt, eftersom Paleocænets Bundlag er glaukonitbetonet eller pyritbetonet.

Paa de Steder, hvor Paleocænets Bundlag er rigt paa Glaukonit, finder man, at Dannelsen af de paleocæne Bjergarter staar i Forbindelse med Nedbrydningen af Danienlagene. Hvor Undergrunden har bestaaet af grove Kalkbjergarter (Bryozokalk, Kalksand), faar det sandede Paleocæn en stor Mægtighed, idet der indgaar meget anki-autoktont Kalksand i Paleocænet (København: sandet Paleocæn paa Kalksand; Lellinge: sandet Paleocæn paa Bryozofragmentkalk o. s. v.). Hvor Undergrunden er finkornede Kalkbjergarter (Kokkolitkalk, event. Skrivekridt), afløses de sandede paleocæne Bjergarter meget hurtigt af Mergel (Hvalløse og Svejstrup: ringe Mægtighed af sandet Paleocæn paa Kokkolitkalk o. s. v.). Det fremgaar saaledes tydeligt af disse Forhold, at de glaukonitbetonede Bjergarter maa være dannet i bevæget Vand, hvor Nedbrydningen af Danienlagene har været stor. 
Hvor Paleocænets Bundlag er pyritbetonet, finder man derimod Slamaflejringer, selv paa grove Kalkbjergarter fra Danienet (Slagelse, Hulby og Ulriksholm: Kertemindemergel paa grov Bryozokalk). Paa disse Steder indgaar der saaledes ikke store Mængder af Underlagets Kalk i Paleocænet, et Bevis paa, at de pyritbetonede Aflejringer er afsat, hvor Erosionen og Bølgebevægelserne har været overmaade ringe. 


\section{Bibliography.}

D. G. U. = Danmarks Geologiske Undersøgelses Skrifter. - Kobenhavn.

M. D. G. F. = Meddelelser fra Dansk Geologisk Forening. — Kobenhavn.

S. N. M. = Forhandl. v. de skandinaviske Naturforskermøder.

Androussow, N. 1897: La mer noire. - Guide des excursions du VII congres international. XXIX. St. Pétersbourg.

Berz, C. 1921: Untersuchungen über Glaukonit. - Jahresber. u. Mitt. des Oberrhein. geol. Vereines, N. F. Bd. 10. Stuttgart.

BøgGiLd, O. B. 1903: Samples of the sea-floor along the coast of East Greenland $741 / 2$ -70 N. L. - Medd. om Gronland, Bd. 28. København.

- 1918: Den vulkanske Aske i Moleret samt en Oversigt over Danmarks ældre Tertiærbjærgarter. (Resumé en français). — D. G. U. II. Rk. Nr. 33.

Caspari, W. A. 1910: Contributions to the chemistry of submarine glauconite. - Proc. Royal Soc. of Edinburgh. 30. Edinburgh.

CAYEux, L. 1897: Contribution à l'étude micrographique des terrains sédimentaires. - Mem. Soc. géolog. du Nord. Tome IV, 2. Lille.

- 1916: Introduction à l'étude pétrographique des roches sédimentaires. - Mém. Carte géolog. détaillée de la France. Paris.

Forchнammer, G. 1843: Nogle geognostiske Iagttagelser over den sjellandske Kridtformation. - Oversigt o. det danske Vidensk. Selsk. Forhandl. i Aaret 1843. Kobenhavn.

- 1849: Det nyere Kridt i Danmark. - 5te S. N. M. 1847., pp. 528 - 555. København.

- 1861: Om Lejringsforholdene og Sammensætningen af det nyere Kridt i Danmark. - 8de S. N. M. 1860. Kobenhavn.

GAGEL, C. 1922: Über Spuren des ältesten Tertiärs in der Mark und über die Stratigraphie des ältesten Tertiärs. - Zeitschr. d. Deutschen Geol. Gesellschaft, Bd. 74, pp. 292-307. Berlin.

Gessner, H. 1931. Die Schlämmanalyse. Leipzig.

GlinkA, K. 1896. Glaukonit. (Russian with German summary). St. Pétersburg. Abstract in Zeitschr. für Krystallographie, Bd. 30. p. 390. 1899.

GröNwall, KARL A. 1897: Block af paleocän från Köpenhamn. - M. D. G. F. Bd.1, Nr. 4.

- 1899: Danmarks yngsta krit- och äldsta tertiäraflagringar. — 15de S. N. M. 1898. Stockholm.

- 1904, 1: Forsteningsførende Blokke fra Langeland, Sydfyn og Erø, samt Bemærkninger om de ældre Tertiærdannelser i det baltiske Omraade. (Résumé en français). - D. G. U. II Rk. Nr. 15.

- 1904, 2. Geschiebestudien, ein Beitrag zur Kenntnis der ältesten baltischen Tertiärablagerungen. - Jahrb. d. Kön. Preuss. Geol. Landesanstalt u. Bergakademie für 1903. Bd. 24. Berlin.

- 1908: En Boring paa Samsø og nogle deraf følgende Slutninger om Danmarks ældre Tertiær. - M. D. G. F. Bd. 3. Nr. 14.

- 1910: Svar paa Prof. Rørdams Bemærkninger«. - M. D. G. F. Bd. 3, p. 477. 
Grönwall, Karl A. og Harder, Poul 1907: Paleocæn ved Rugaard i Jydland og dets Fauna. (Résumé en français). — D. G. U. II Rk. Nr. 18.

HAdDing, Assar 1932: The prequaternary sedimentary rocks of Sweden. IV. Glauconite and glauconitic rocks. - Medd. Lunds geol.-mineral. institution Nr. 51. Lund.

Hansen. Sigurd 1930: Om Forekomsten af Glacialflager af paleocæn Mergel paa Sjælland. (Zusammenfassung in Deutsch). - D. G. U. IV Rk. Bd. 2, Nr. 7 and M. D. G. F. Bd. 7 .

Harder, Poul 1922: Om Grænsen mellem Saltholmskalk og Lellinge Gronsand og nogle Bemærkninger om Inddelingen af Danmarks ældre Tertiær. (Résumé en français). - D. G. U. II Rk. Nr. 38.

Holst, N. O. och Grönwall, Karl A. 1907: Paleocen vid Klagshamn. - Sveriges geologiska Undersökning, Ser. C No. 208 (Årsbok 1 No. 5). Stockholm.

Holtedahl, Olaf 1918: Bidrag til Finmarkens Geologi. - Norges Geol. Undersøkelse, Nr. 84. Kristiania.

Hummet, K. 1922: Die Entstehung eisenreicher Gesteine durch Halmyrolyse (submarine Gesteinszersetzung). — Geol. Rundschau Bd. 13. Berlin.

Johnstrup, F. 1869: Om Brunkulsdannelserne i Danmark ... - 10de S. N. M. 1868, p. LXVII. Christiania.

- 1876: Om Grønsandet i Sjælland. - Vidensk. Medd. fra d. naturhist. Forening i Kjøbenhavn. København.

Klemm, Gustav 1882: Microskopische Untersuchungen über psammitische Gesteine. Zeitschr. d. Deutschen Geol. Gesellschaft, Bd. 34. p. 771. Berlin.

von Koenen, A. 1885: Ueber eine Paleocäne Fauna von Kopenhagen. - Abh. d. Königl. Gesellsch. d. Wiss. zu Göttingen, Bd. 32. Göttingen.

- 1886: Ueber das Mittel-Oligocän von Aarhus in Jütland. — Zeitschr. d. Deutschen Geol. Gesellschaft, Bd. 38. p. 883. Berlin.

LugN, A. L. 1927: Sedimentation in the Mississippi river. - Augustana Library Publ. Nr. 11. Rock Island. Ill.

Loughlin, G. F. 1929: Indiana oolitic limestone. - United States Geol. Survey Bull. 811 C. Washington.

Madsen, Victor 1902: Kortbladet Nyborg. (Résumé en français). - D. G. U. I Rk. Nr. 9.

- 1928: Summary of the Geology of Denmark. - D. G. U. V Rk. Nr. 4.

Madsen, Victor, Ødum, H. og Gry, H. 1935: Boringerne ved Langbrogaard ved Sønderborg. - D. G. U. II Rk. Nr. 55.

Mertz, Ellen Louise 1928: Lillebæltsler og London Clay. (English summary). D. G. U. II Rk. Nr. 51.

Milthers, V. 1907: Det ældre Tertiærs Udbredelse i det nordvestlige Sjælland. — M. D. G. F. Bd. 3, p. 97.

- 1908: Kortbladene Faxe og Stevns Klint. (Résumé en français). — D. G. U. 1 Rk. Nr. 11.

- 1919: Mergelen i Djursland. — D. G. U. III Rk. Nr. 18.

- 1923: Kalk og Mergel paa Sjælland. - D. G. U. III Rk. Nr. 23.

Mørсн, O. 1874: Nye Tertiærforsteninger i Danmark. 11te S. N. M. 1873. København. Murray, J. and Irvine, R. 1895: On the chemical changes which take place in the composition of the sea-water associated with Blue muds on the floor of the ocean. Transact. of the Royal Soc. of Edinburgh. Vol. 37, pp. 481-507. Edinburgh.

Nielsen, K. Brünnich 1910: Om det i København ved Knippelsbro fundne yngste Danien. - M. D. G. F. Bd. 3, p. 463.

- 1919: En Hydrocoralfauna fra Faxe og Bemærkninger om Danien'ets geologiske Stilling. (Résumé en français). - D. G. U. IV Rk. Bd. 1 Nr. 10 and M. D. G. F. Bd. 5 Nr. 16. 
Ravn, J. P. J. 1903: Molluskerne i Danmarks Kridtaflejringer, III Stratigrafiske Undersøgelser. - Det Kgl. Danske Vidensk. Selsk. Skr., 6 Rk. naturv. og math. Afd., 11. Bd., VI. Kobenhavn.

- 1922: Geologisk Kort over Danmark. Dybere liggende Dannelser. (Texte danois et français). D. G. U. III Rk. Nr. 22.

RosenkJÆr, H. N. 1895: Fra Frihavnens Bund. - Naturen og Mennesket. Aarhus.

Rosenkrantz, Alfred 1920: Craniakalk fra Kjobenhavns Sydhavn. (Résumé en français). - D. G. U. II Rk. Nr. 36.

- 1924: De københavnske Gronsandslag og deres Placering i den danske Lagrække. — M. D. G. F. Bd. 6 Nr. 23.

- 1925: Undergrundens tektoniske Forhold i København og nærmeste Omegn. M. D. G. F. Bd. 6 Nr. 26.

- 1930: Den paleocæne Lagserie ved Vestre Gasværk. (Mit einer Zusammenfassung). M. D. G. F. Bd. 7.

- 1934: Notits vedrørende en Brudlinje i det sydøstlige Københavns Undergrund. M. D. G. F. Bd. 8, p. 407.

Rørdam, K. 1897: Kridtformationen i Sjælland i Terrænet mellem Kjøbenhavn og Kjøge og paa Saltholm. (Résumé en français). — D. G. U. II Rk. Nr. 6.

Rørday, K. og Milthers, V. 1900: Kortbladene Sejrø, Nykjøbing, Kalundborg og Holbæk. (Résumé en français). - D. G. U. I Rk. Nr. 8.

Udden, J. A. 1898: The mechanical composition of wind deposits. - Augustana Library Publ. Nr. 1. Rock Island. IIl.

- 1914: Mechanical composition of clastic sediments. - Bull. of the Geol. Soc. of America, Vol. 25.

Ussing, N. V. og Madsen, Victor 1897: Kortbladet Hindsholm. (Résumé en français). D. G. U. I Rk. Nr. 2.

Ussing, N. V. 1899: Danmarks Geologi i almenfatteligt Omrids. - D. G. U. III Rk. Nr. 2.

— 1907: Om Floddale og Randmoræner i Jylland. — Det Kgl. Danske Vidensk. Selsk. Forhandl 1907. Nr. 4. København.

Vogt, J. H. L. 1905: Úber anchi-eutektische und anchi-monomineralische Eruptivgesteine. - Norsk geol. Tidsskrift, Bd. 1 Nr. 2. Kristiania.

Wentworth, Ch. K. 1922: A Scale of Grade and Class Terms for Clastic Sediments. - Journ. of Geology, Vol. 30, p. 377. Chicago. Ill.

- 1926: Methods of Mechanical Analysis of Sediments. - Univ. of Iowa Studies. Studies in Nat. Hist. Vol. XI Nr. 11.

Ønum, Hilmar 1926: Studier over Daniet i Jylland og paa Fyn. (English summary). - D. G. U. II Rk. Nr. 45.

- 1932: Mindre Medd. fra D. G. U.s Borearkiv, Nr. 8. - M. D. G. F. Bd. 8, p. 190. 


\section{Index to Localities.}

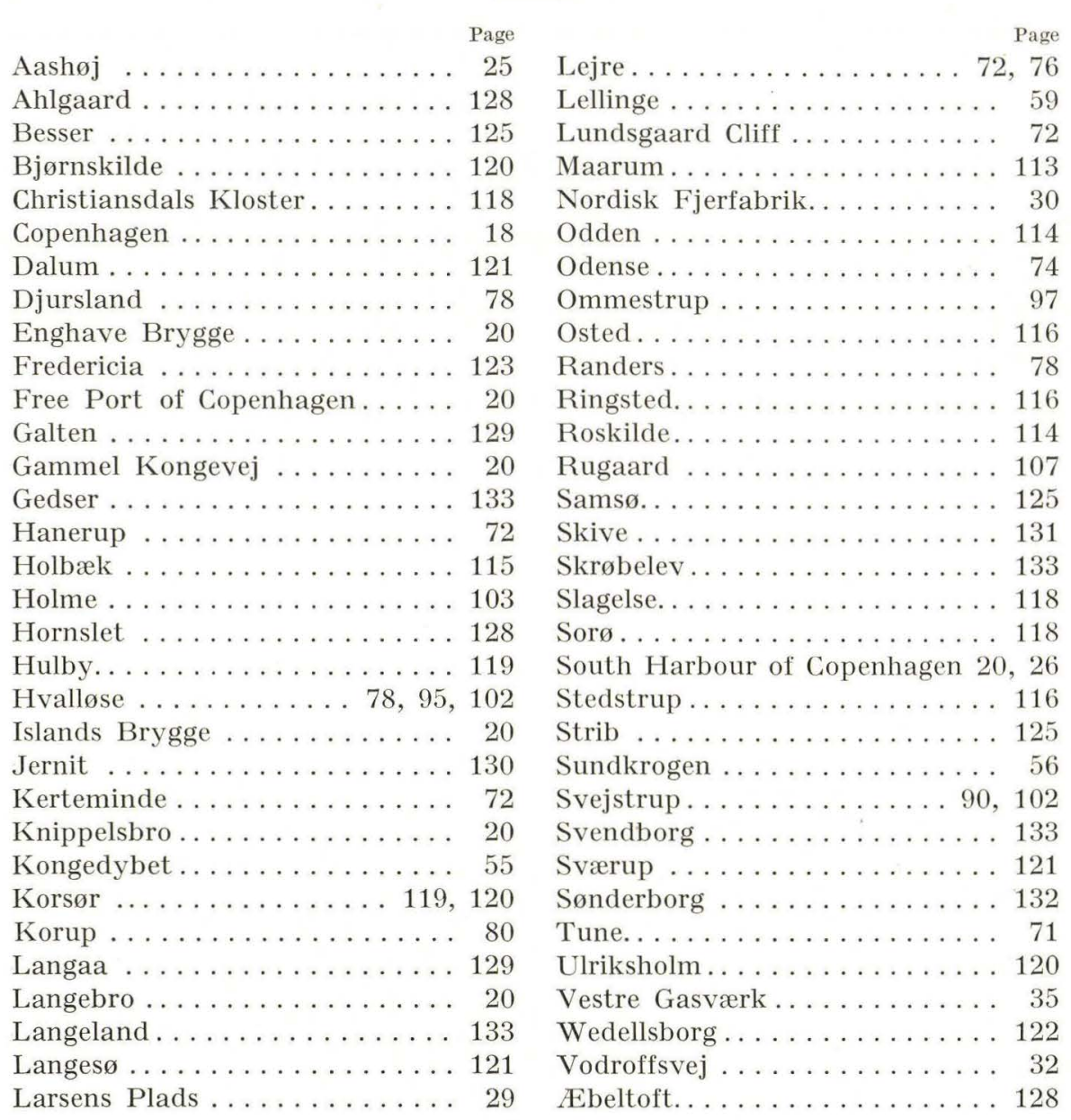


PLATES 


\section{Plate 1.}

All the microphotographs have been taken with 1 nicol.

Fig. 1. Shelly conglomerate, South Harbour, Copenhagen. $\times 6.3$ (Page 27). Glauconitized rounded shells and lime grains lying in a clear calcite cement. At the top left a Terebratula shell with glauconite in the pores. The round, black grains are coproliths.

Fig. 2. Shelly conglomerate, Larsens Plads, Copenhagen. $\times 17$ (Page 29). The oolitic calcite zone is slightly dark. At the bottom right stalactitic masses of calcite. The zone of sphaerulitic chalcedony is white. At the bottom the interstice is quite infilled with chalcedony.

Fig. 3. Pyritized shelly conglomerate, Nordisk Fjerfabrik, Free Port, Copenhagen. $\times 3.6$ (Page 30). The greater part of the picture shows a high degree of cementation by pyrite, only irregular shaped remnants of the lime grains remaining. At the top, pure as well as pyritized lime grains lying in a clear calcite cement.

Fig. 4. Phosphoritized greensand, Vestre Gasværk̃, Copenhagen. $\times 42$ (Page 54). Lime grains covered by a skin of phosphorite, and within this, phosphorite for a great part has replaced the calcite. Glauconite grains as well as glauconite pigment and pyrite remain in the original form.

Fig. 5. Glauconitized limestone pebble, South harbour, Copenhagen. $\times 36$ (Page 32). The boundary between the pebble and the greensand limestone is in the upper part of the picture, where there are large masses of glauconite. From there the glauconite can be seen extending into the pebble, where it envelops angular, clear calcite grains, which are remnants of the calcite cement.

Fig. 6. Shelly gravel, Vodroffsvej, Copenhagen. $\times 16$ (Page 33). Rounded and irregularly formed shell fragments packed together in a dark matrix. In the middle of the picture dark masses of glauconite as cement. 

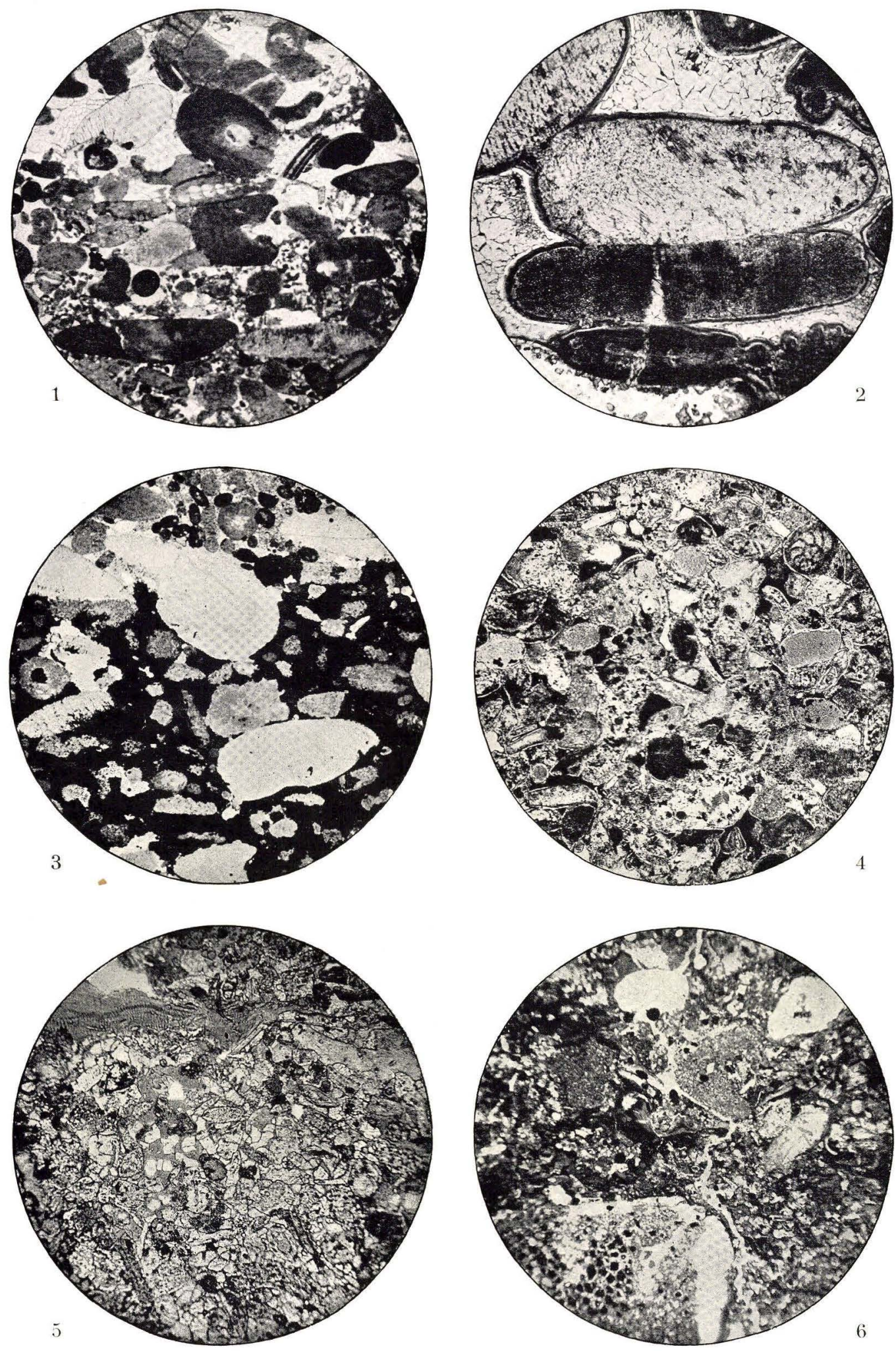


\section{Plate 2.}

Fig. 1. Greensand, Vestre Gasværk, Fraction $0.1-0.2 \mathrm{~mm}$, treated with dilute acid. $\times 35$ (Page 46). Rounded quartz grains, partly with glauconite on the surface; glauconite grains and irregularly formed masses of glauconite from the glauconitized lime-sand grains.

Fig. 2. Kertemindemarl, Kerteminde, Fraction $0.2-0.5 \mathrm{~mm}$, treated with dilute acid. $\times 40$ (Page 75). Triangular and disk-shaped pyrite concretions formed in diatoms: rods and needles, formed in sponge spicules, and tiny isolated pyrite spheroids.

Fig. 3. Silicified greensand and chert, Lellinge. $\times 17$ (Page 65). At the top the most common type, with sponge spicules transformed into chalcedony; at the bottom flinty, strongly silicified rock, in which the greater part of the rock has been replaced by chalcedony.

Fig. 4. Greensand limestone, Lellinge. $\times 18$ (Page 66). The clear calcite casts of the sponge spicules appear in section as light circular and rod-shaped figures.

Fig. 5. Glauconitic marl, Svejstrup. $\times 12$ (Page 91). Scattered in the fine grained rock are lobate glauconite grains (grey) and joined to them masses of pyrite, partly replacing the glauconite, partly the marl.

Fig. 6. Non-calcareous silicified greensand, Rugaard. $\times 42$ (Page 109). Scattered in the silicified matrix (grey) are quartz splinters, sponge spicules and glauconite grains (dark grey); pyrite black. In the middle of the picture a radiolarian skeleton. 

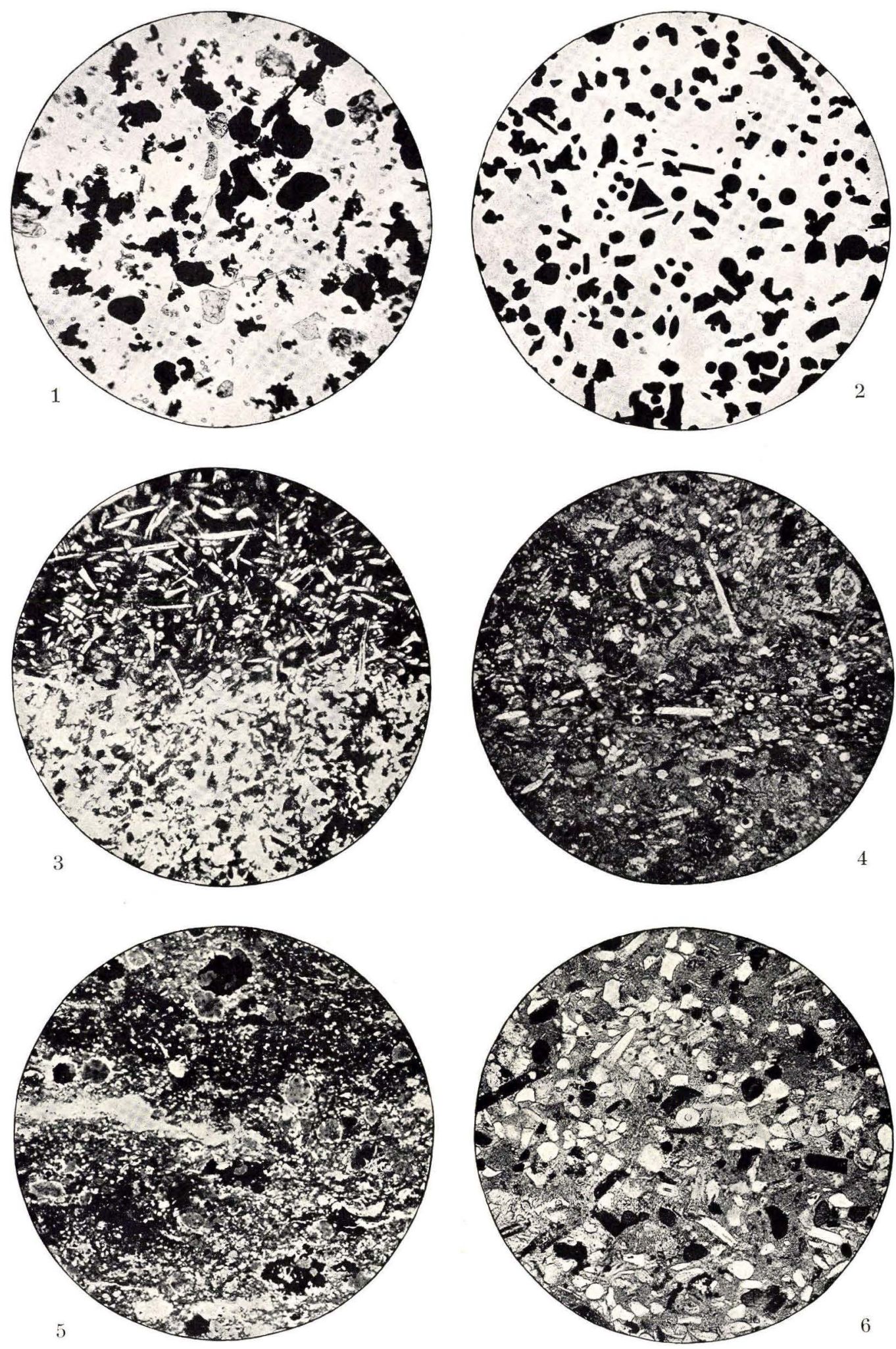